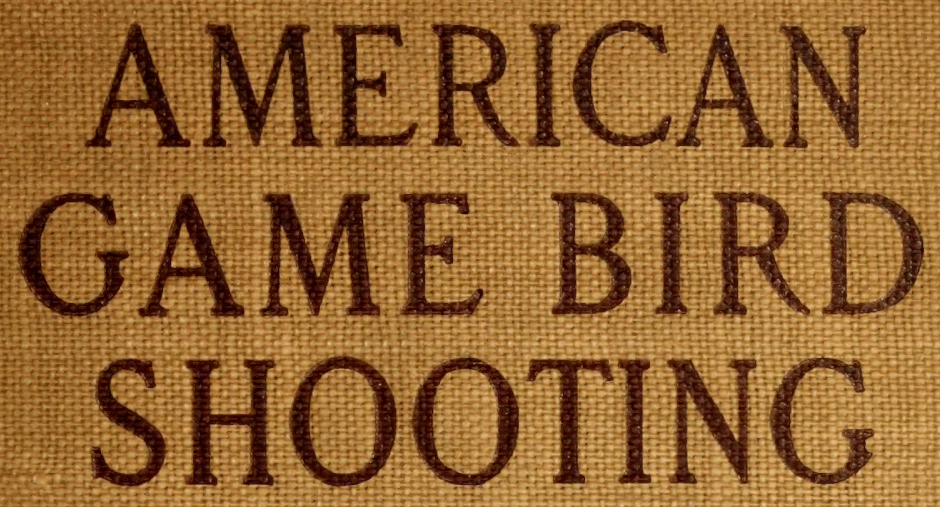

GRINNELL 

S. R. Riley 7allochurch. Pirginia. 








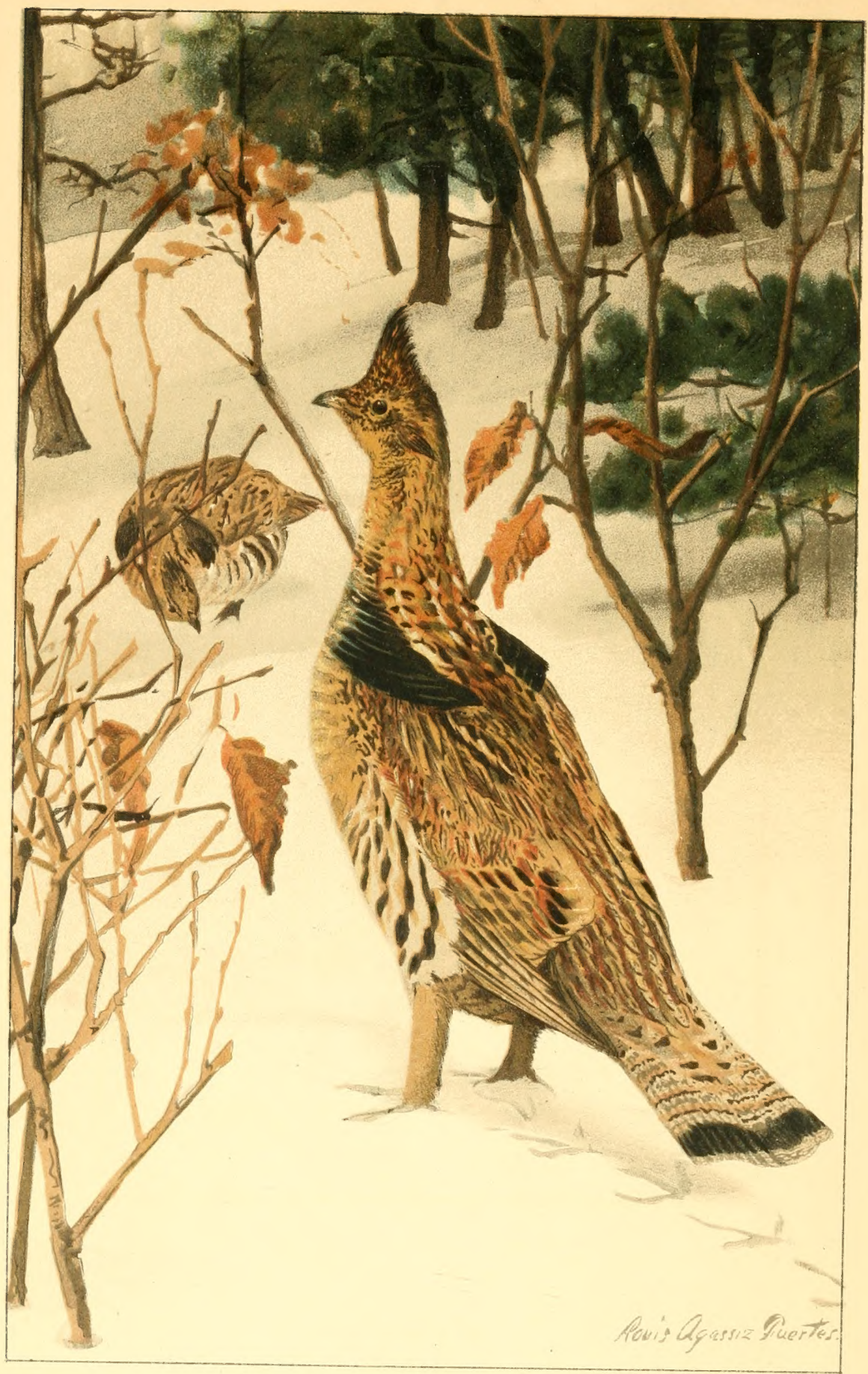




\section{AMERICAN GAME-BIRD SHOOTING}

By George Bird Grinnell

Author of PAWNEE HERO STORIES AND FOLK-TALES BLACKFOOT LODGE TALES THE STORY OF THE INDIAN THE JACK SERIES AMERICAN DUCH SHOOTING, etc., etc.

With Colored Plates of $R$ uffed Grouse and $B o b w h i t e$, Forty-eight Full-page Portraits of Game $B i r d s$ and Shooting scenes, and many Cuts in Text

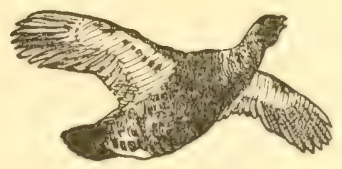

NEW YORM

Forest and Stream Publishing Company

269465 


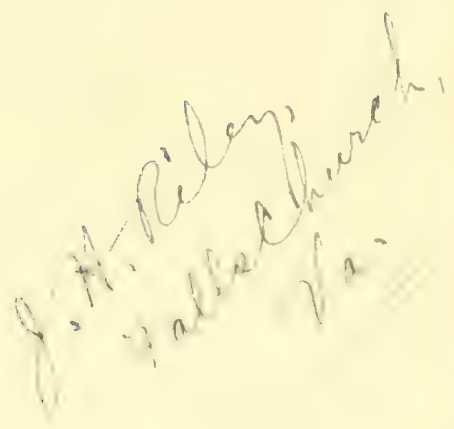




\section{PREF A GE}

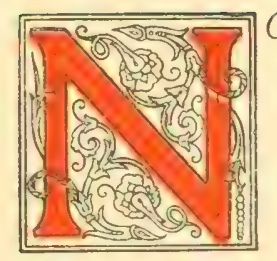

FULL AND COMPLETE work on American upland shooting has as yet been written. Volumes have been published, each of which covers some section of what is really a large subject, but from the broader sportsman's viewpoint no one of them is complcte. Of these works, the most useful was written by the veteran naturalist and sportsman, D. G. Elliott, whose "Game Birds of North Amcrica" deals chictly with the natural history side of the grouse and quails, and touches only lightly on the methods by which they are pursued for sport.

It seems time now that a book should be written, covering the whole subject of upland American gamebird shooting; that is, the shooting of those birds in which the pointing dog is the assistant to the gunthe turkeys, grouse and quail, and the American woodcock and Wilson's snipe, called also "English" and "jack" snipe, a bird of continental distribution.

Some years ago I brought together a large amount vii 


\section{PREFACE}

of material on duck shooting in North America, and the gratifying reception met by that volume encourages me to believe that there is place for a companion work, which shall appeal especially to men who tramp the uplands with gun and dog. They may perhaps welcome a book which shall deal with their favorite sport, and shall touch on it as practiced in different parts of the country.

No two men use the terms shooting and hunting in the same reay, and if the question could be submitted to a general conference of sportsmen, wide differences of opinion as to what constitutes a game bird would of course be found to exist. In certain sections of the country, and among certain classes of people, bluejays and woodpeckers are regarded as legitimate objects of the gunner's pursuit; if they are less highly esteemed than quail and prairie chicken, it is only because they weigh less.

For the purposes of this book I have considered as game birds only the species that are commonly hunted with dogs. This naturally throws ont of the list many birds which offer good sport and are excellent for the table. Such are many of the plovers and beach birds, the Bartramian sandpiper, and all the rails.

In the preparation of the volume I have not hesitated to draw for information on all available sources, viii 
and I have striven to bring together much matcrial of interest to the sportsman which is now scattered through many volumes and periodicals, and is thus not easily accessible.

The plan of the book does not differ essentially from that of "American Duck Shooting." Its first part is devoted to descriptions of the birds and their habits, the second part to the various methods cmployed in taking the birds and the aids to shooting-dogs, guns and anmmition; while in the third is discussed the shooting of the future.

I have reccived at sevcral hands valuable assistance, which I desire here to acknowledge. Dr. A. K. Fisher, of the Biological Survey of Washington, a kccn sportsman and experienced ornithologist, kindly read over the manuscript. Mr. B. Watcrs, distinguished as a crack shot, and especially lcarned in the hunting dog, is chicfly responsible for the chapters cspecially $d e-$ voted to dog and gun. To the kindness of Mrs. Vernon Bailey and of the Houghton, Miffin Co. I owe the excellcut plates of the scaled quail and Mcarns' quail, taken from her "Handbook of Birds of the Western United States." Messrs. Little, Brown \& Company give me permission to reproduce several cuts from Baird, Brewer and Ridgway's "North American Birds." The Forest and Strcam Publishing Company ix 


\section{PREFACE}

has allowed me to enrich the book with a wealth of illustrations not always to be had in such a volume. The colored plates of the ruffed grouse and Virginia quail, so admirably depicted by Mr. Louis Agassiz Fuertes, I use by the kind permission of the Biological Survey of the Department of Agriculture, who also lct me have the excellent figures of the sage grouse and of Gambel's quail. Dr. C. F. Hodge, of Clark University, Worcester, Mass, has furnished me with a number of beautiful photographs of his ruffed grouse and bobwhites.

Sportsmen and ornithologists will find here much that is familiar, but, I hope, also something that is new.

Geo. Bird Grinnell.

New York, October, I9IO. 


\section{CON'TENTS}

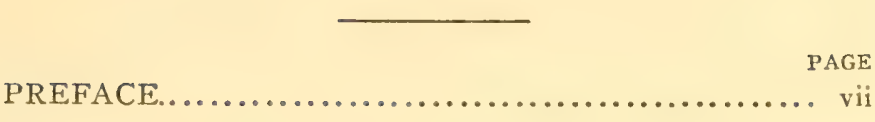

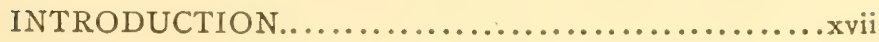

PART I

AMERICAN GAME BIRDS

SNIPE-LIKE BIRDS..................... I

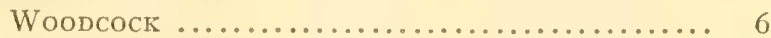

American Snipe........................... 30

GALLINACEOUS BIRDS.................. 40

THE AMERICAN QUAIL................. 47

Quail, Bobwhite, Partridge............. 49

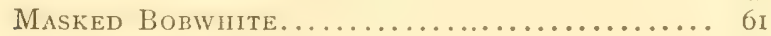

Mountain Quail......................... 76

Scaled QuaIL.......................... 8r

California Quail, Valley Quail........... 85

Gambel's Quail....................... 9I

Massena or Mearns' QuaIl................ I06

THE AMERICAN GROUSE................ II

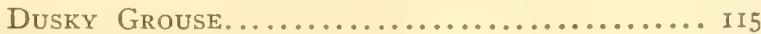

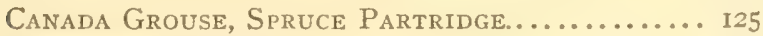

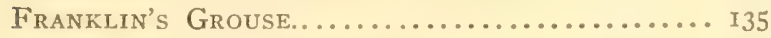

Ruffed Grouse, Partridge................ 139 xi 
THE AMERICAN GROUSE-(Continued).

Willow Ptarmigan......................... 168

Rock Ptarmigan........................ 187

White-tailed Ptarmigan.................... 193

Pinnated Grouse......................... 206

Sharp-tailed Grouse..................... 25I

SAge Grouse............................ 272

THE WILD TURKEY...................... 282

PART II

\section{UPLAND SHOOTING}

UPI AND SHOOTING ...................................

PAGE

WoOdсоск SноOTING.......................... 305

Snipe Shooting............................... 319

Quall Shooting................................ 332

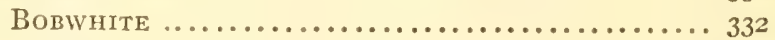

Valley Quail............................. 350

Gambel's Quatl............................ 352

Mountain Quall............................ 353

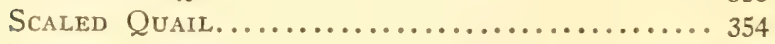

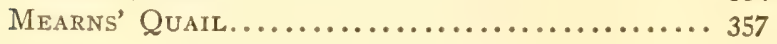

SHOOTING THE WOODS GROUSE.............. 359

Ruffed Grouse.............................. 359

Dusky Grouse......................................... 384

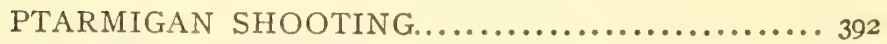

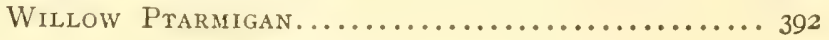

SHOOTING THE PRAIRIE GROUSE............. 398

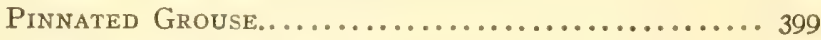

Sharp-tailed Grouse........................ $4^{\mathrm{I} 2}$

SAGE Grouse.............................. $4{ }^{1} 6$ xii 
TURKEY SHOOTING...................... PAGE

422

AIDS TO SHOOTING..........................437

Clothing................................... 457

GunS AND LOADS............................ 462

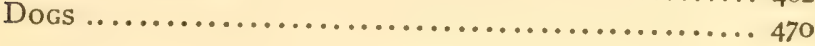

PART III

\section{THE SHOOTING OF THE FUTURE} GA.

Transplanting American Game Birds............ 527

Destruction and Protection.......................... 536

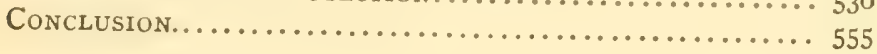

xiii 


\section{LIST OF ILLUSTRATIONS}

\section{PART I}

TO FACE PAGE

Ruffed Grouse. (Colored Plate)..............Frontispiece

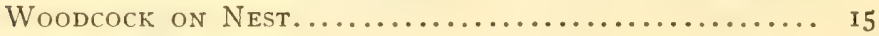

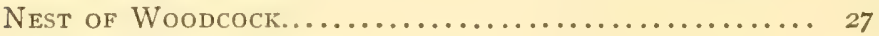

Nest of Wilson's Snipe...................... 33

Mountain Quall.......................... 79

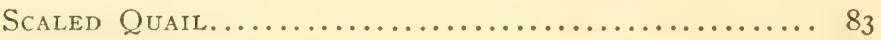

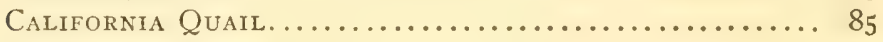

Nest of California Quall..................... 89

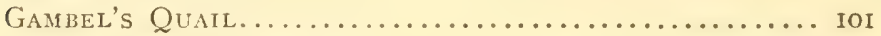

Massena or Mearns' Quall..................... IO

Sierra Dusky Grouse and Young................. II

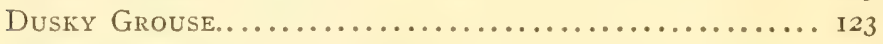

Canada Grouse. (After Audubon's Plate)............. I3I

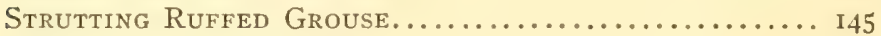

The Drumming Grouse....................... I 49

Nest of Ruffed Grouse...................... I5I

DAY-DREAMING........................... I6I

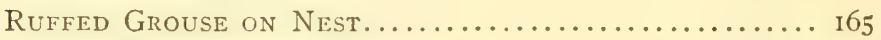

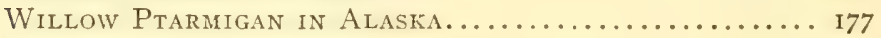

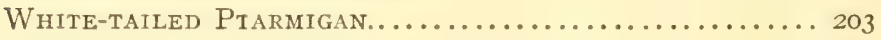

Pinnated Grouse and Nest..................... 22 I

Sharp-tailed Grouse. (After Audubon's Plate)......... 257

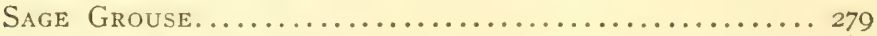

Wild Turkeys Feeding....................... 289

Wild Turkey Strutting....................... 297 


\section{LIST OF ILLUSTRATIONS}

\section{PART II}

PAGE

TO FACE PAGE

Bobwhite in Potato Field. (Colored Plate).......... 305

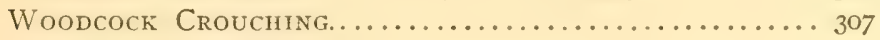

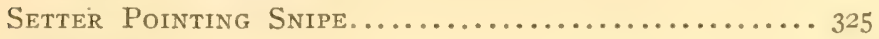

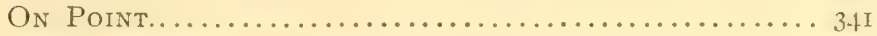

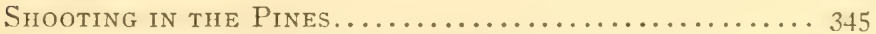

Setter Pointing, with Bird in Mouth............... 36i

Ruffed Grouse Cock, Reared in Domestication....... 377

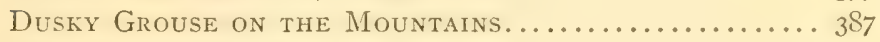

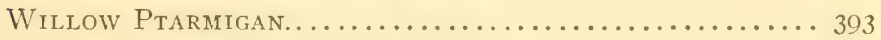

Prairie Chicken Shooting in Kansas.............. 405

Pointers Fast on Chickens................. 4 I I

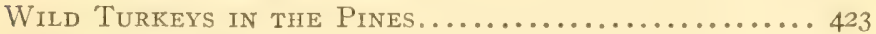

Setter Standing a Ruffed Grouse.............. 47 I

Delivering the Bird....................... 487

Shooting IN Mississippi. (Painting by Edmund Osthaus). 503

\section{PART III}

TO FACE PAGE

Bobwhite Chick, Three Weeks Old............... 5 II

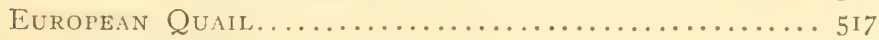

Hybrid Dusky Grouse-Pheasant................. 519

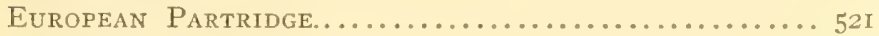

Double Handful of Quail..................... 537

Winter Quarters of Dr. Hodge's Quail............ 539

Ruffed Grouse Chicks Just Hatched............. 54 I

Feeding Bobwhite Chicks.................. 545

Bobwhite Reared by Dr. C. F. Hodge............. 547

Ruffed Grouse Feeding from Hand............. 55 I 


\section{LINE CUTS IN TEXT}

PAGE

RANGE OF THE WOODCOCK. (Map)................ 7

Bill, Foot, Tail and Wing of Bobwhite........... 50

Bill and Foot of Mountain Quall............... 77

Bill and Foot of Scaled Quail................. 82

Bill and Foot of California Quail............... 86

Bill, Foot and Wing of Mearns' Quail............ IO7

Bill, Foot, Tail and Wing of Dusky Grouse......... il6

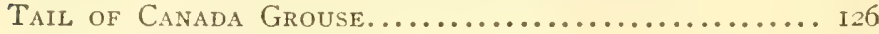

TaIl of FrankLin's Grouse..................... I36

Bill, Foot, Tail and Wing of Ruffed Grouse......... I40

Bill, Foot, Tail and Wing of White-tailed Ptarmigan. 194

Bill, Foot, Tail and Wing of Pinnated Grouse....... 207

Bill, Foot, Tail and Wing of Sharp-tailed Grouse.... 252

Bill, Foot, Tail and Wing of Sage Grouse.......... 273

Bill, Foot, Tail and Wing of Wild Turkey......... 283 


\section{NTRODUCTION}

The astonishingly rapid increase of population in the United States has resulted in an equally startling decrease in America's larger fauna, especially in those mammals, birds and fishes which are useful for food. The story of the extermination of large animals over vast areas is familiar to all, and men not yet beyond middle life have themselves seen the extermination of food birds over much of the country east of the Mississippi and north of the Ohio River. Even young men can remember when the prairie chickens abounded in Iowa, Minnesota and Nebraska, in regions where now there are but few.

As the game became more scarce the importance of preserving it began gradually to be appreciated. Yet in a thickly settled region it is very difficult to efficiently protect the game. Obviously, the best way to accomplish this is to interest the general public in it, to point out the economic value of the game birds, and to secure for the authorities, whose work it is to enforce the laws, the backing of public opinion in behalf of those laws. 


\section{INTRODUCTION}

The number of people who are trying to accomplish something in this good work in America is greater now than ever before, and the promise of good results is brighter than it has been. On the other hand, in many sections the stock of native birds is pitifully reduced, so that while once the only persons who used the shotgun were the field shooters, to-day the number of men who shoot afield is small by comparison with those who use the shotgun at clay targets thrown into the air from a trap.

The good sportsman-good in the sense of being devoted to the ethics of sport, and in the sense of being successful in his pursuit of game-wishes to know all he can about the life ways of the beautiful birds that he seeks for, and in getting together the material for this book I have endeavored to keep this fact constantly in mind. 


\section{American Game Bird Shooting}

\section{SNIPE-LIKE BIRDS}

\section{Limicolc.}

The great order Limicolc stands between the gallinaceous birds on the one hand, and the herons, cranes, rails, and their allies on the other. This order, known as shore bircls, or the plover-snipe group, is a large and cosmopolitan order. The species are usually of small size and the legs are long, as is usually-but not always - the bill. In certain of its characters the skeleton resembles those of the gulls and auks. The birds live in open places on the ground and usually near water or in moist situations-though to this rule there are marked exceptions. The young leave the nest and run about as soon as hatched; in other words, as the naturalists say, they are præcocial. The eggs are few in number, averaging about four. The food is chiefly insects, worms, small shellfish or other soft animals which are found in sand or mud. The wings as a rule are long, flat and pointed, but are sometimes rounded. The tail is usually short. The head is almost always 
covered with feathers and in some cases there is a distinct crest.

The bill varies greatly, from short in some species to long in others. In one species it turns up, in another is bent to one side, often it is curved downward, and sometimes it is oddly expanded at the end, or it may be compressed to a knife shape. Usually it is covered with a soft skin, is often much swollen and in some cases is a very sensitive organ of touch. The nostrils open above in a groove. They are never feathered.

The sexes are usually alike, though they differ in the phalaropes, the jacana and the European ruff. The breeding dress is often quite different from that of the autumn, and some species are extremely showy in their spring plumage.

Within this order are found two great families that are peculiarly familiar to American gunners. These are the Charadriidce, or plover family, with a dozen or fifteen species, and the Scolopacide, or snipe family, which contains more than forty species, and in which are found the only two here to be considered. Besides these two great families, there are other smaller ones, which include the oyster catchers and turnstones, the avocet and stilt, and the phalaropes.

Not very distantly related to this group is the bustard family of the Old World, some of which reach a size near that of the American wild turkey. This bustard family, according to Cones, perfectly connects the shore birds with the Alectorides, or cranes, rails and their allies. 
The only birds that we have to consider in this connection belong to the snipe family, which may be separated into several groups. All snipe-like birds have long bills usually covered with a sensitive skin, which is soft throughout and furnishes to the bird a useful organ of touch. While the bill is long, it is never wide - though in one or two cases expanded at the tip; the nostrils are short, narrow slits. The toes are usually four, though in two or three cases there are but three. Usually they are separated, but in a few species they are palmated or semi-palmated. The neck and legs are usually long and the legs seldom feathered down to the tarsal joint. Most of the birds belonging to this family are of small size, but occasionally, as in the curlews, the birds are as large as a small domestic fowl.

Snipe and sandpipers are exceedingly gregarious, traveling in flocks whose numbers can hardly be counted. This makes them especially subject to danger from gunners, and the birds being gentle and unsuspicious may often return to the decoys over and over again after being shot at. Over-shooting and lack of enforced protection has almost put an end to the shorebird shooting on a great part of the Atlantic coast.

Snipe-like birds usually build in or near marshy places or by water, and as a rule lay four eggs. The voice is a shrill, but often sweet, whistle, readily imitated and used to lure the birds to decoys. Ornithologists state that there are about ninety well-marked species of these birds, which are divided into five groups, the first containing the woodcock and snipe, the 
second the godwits, the third the sandpipers, the fourth the tattlers, and the fifth the curlews.

In the woodcock and true snipe the eye is placed high up on the head, so that the ear is below it, and, as Dr. Coues says, if the brain be examined it will be found curiously tilted over so that its anatomical base looks forward. The bill is straight and is much longer than the head. It is deeply grooved almost to its very end, where it is conspicuously swollen and soft. The soft, sensitive covering of the bony bill is abundantly supplied with nerves, and the bill is an instrument of touch by which the bird feels in the soft earth where it feeds for the food which it desires. Not only is the bill used as a direct probe, but it is capable of being somewhat bent in one way or another. Any one who has ever compared the bill of the dried skin of a woodcock or a snipe with that of a fresh specimen has probably noticed that the dried bill is much shrunken and is also pitted, showing where the more or less thin skin which covers the bill has shrunken into the pits in its bony substance.

Woodcock and the snipe differ from many of their allies in not being gregarious. They do not gather in great flocks and so cannot be destroyed in immense numbers. On the other hand, they are very simple, gentle birds, and the woodcock living in cover is easily shot, though the snipe is better able to care for himself.

The godwits are large birds with long, grooved bills slightly turned up instead of down. They frequent wet meadows and marshes as well as bays and estuaries, and 
are as truly bay and shore birds as are the sandpipers. There are not many species.

The sandpipers are a large group, and among them are some species with peculiar bills. The bill is soft and sensitive, though less so than in the two previous groups. All the sandpipers are extremely gregarious, and while they vary somewhat in size, as a rule they are small birds.

The tattlers, of, which the winter and the summer yellowleg and willet are familiar examples, are larger than the sandpipers and longer legged. In these birds the bill is less sensitive than in the sandpipers. They are not less gregarious than the previous group, and are noted for their restlessness and for the noise they make, whence their common name. It is a large group.

The curlews are distinguished by a down-turned sensitive bill of great length, and in most cases by their large size. These also are noisy birds and remind one somewhat of the godwits, which nearly equal some of the curlews in size. Both godwits and curlews are found all over the world.

The flesh of all these birds is usually very delicious, though of course varying in excellence with the foods of the species. Some of these which feed along the shore and largely on shellfish are not particularly well flavored, while the woodcock and snipe are among the most delicate of our game birds. 


\section{WOODCOCK}

\section{Philohela minor}

The American woodcock is a small bird, weighing only from five to nine ounces. He is eleven or twelve inches in length, and of this the bill occupies from two and one-half to three inches. The plumage below is rich russet-brown, paling, on the upper breast, sides of the neck and forehead, to ashen-gray. The crown is black, with two or three crosslines of tawny, and the back is curiously mottled with tawny, ash-gray and black, the latter predominating. The tail feathers are black, barred with tawny, their tips smoky-gray on the upper side and snow-white beneath. The legs and feet are pale flesh-color, the bill dark horn-color at the tip, becoming paler at the base, and the large, soft, humid eyes are brown.

The range of the woodcock is from Canada south to the limits of the United States and west to beyond the Mississippi River, but the high, dry plains of the trans-Missouri region limit the extension of his range westward, for he is a bird that loves moisture and cool, dark thickets. His range is shown on the accompanying little map taken from Dr. Fisher's article, in the Year Book of the Department of Agriculture for I90I. 
The English woodcock, so called-by which is meant the woodcock of Europe-is twice the bulk of the American bird, and though in a general way similar in color, the pattern is so different that the two could never be confused, even though they were of the same size. This European bird has occasionally been

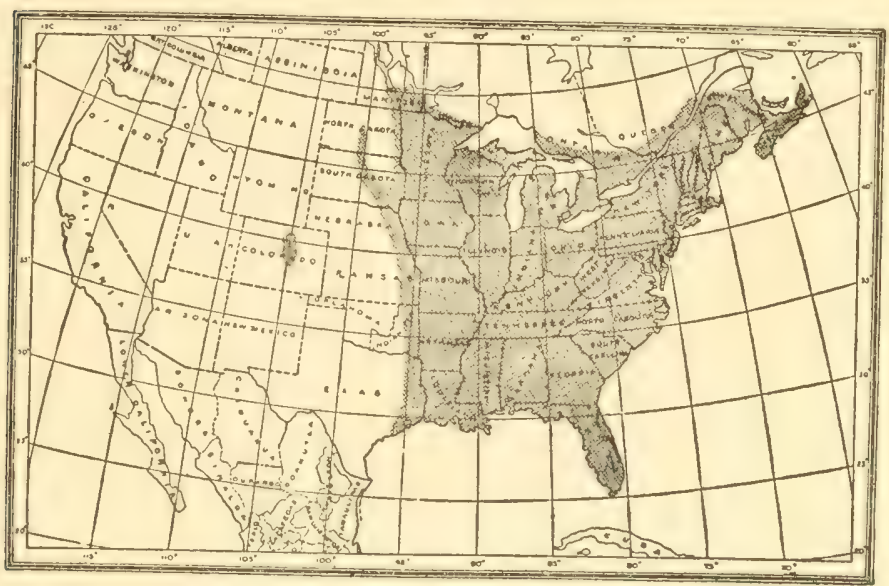

RANGE OF THE WOODCOCK

taken in America. Any sportsman who may chance to kill a woodcock twice the size of the ordinary bird, paler in color and distinctly cross-barred, should by all means have it at once examined by a naturalist; and if unable to reach a naturalist, he should have the skin preserved, and should report the occurrence.

Many of the woodcock pursue their winter journeys as far south as the Gulf of Mexico, while others winter much farther to the north. In fact, it is not altogether 
unexampled for them to winter as far north as Connecticut, provided they can have a certain amount of shelter and the weather is mild enough, so that their feeding grounds are not sealed up by the frost. On the other hand, the birds which do not go farthest to the southward may occasionally suffer by unexpected and severe freezes, such as took place in February, I899, to be spoken of further on. Wherever it goes, the woodcock starts early for its summer home and is often found breeding in New Jersey in the month of March.

The woodcock is thus one of the early spring migrants, and, soon after his arrival, which is usually in March or early April, according to the weather, he makes his presence known, to those who understand where and when to listen for him, by the curious night song with which he wooes his mate. This song has been interestingly described by Walter $\mathrm{H}$. Rich in the Journal of the Maine Ornithological Society for June, igro. He says:

"As we walked along in the dusk, ... my companion called my attention to a bird note which was new to him. I listened a moment, and then said, 'The first night hawk, I think.' An instant later I doubted, and at once my doubt was confirmed when there sounded again the nasal $p-a-a-n c k$ ! $p-a-a-n c k$ ! of a woodcock. Soon we heard him whistle somewhere on wing, and presently he appeared flying about, high up under a particularly bright star, where he sang and trilled and twittered. I do not remember having ever 
before heard a woodcock make so much, so varied and so good music. It was a veritable song, and many a so-called songbird does not possess such a repertoire as did he.

"The night was clear and cloudless, with no moon, but bright with starlight, so that there was no difficulty in following every development. I think he went through his performance at least a dozen times, with intervals of rest between of not more than a minute. On each occasion he came to earth near by us, always within fifty yards, and nearly always within thirty feet, seeming to have some curiosity as to our presence and intentions, but showing very little fear. In one instance he had almost settled upon the ground, within three feet of me, before noticing my motionless figure; either that, or, as may be possible, he was examining his disturbers at close range, for, flying first close to my companion, and making a half circle about his head, he approached me, poised an instant within hand reach, and then came to earth not over ten feet away.

"When I approached him as he rested upon the ground he made a peculiar guttural note, which I cannot describe better than to say that it was like the faint, muffled $b-0-o-m p$ of a bullfrog. I stood quietly waiting until he should resume, which he presently did, jerking out, with much bobbing of head and twitching of tail, a series of nasal, rasping quancks! After a little he whistled away again, circled, twittered, sang, and dropped to earth. He must have made eight or 
ten flights before I left him, and from all indications was ready to make as many more.

"A week later a party of four of us made an excursion into the cover to listen to my twilight musician, and, though the wind was high and conditions seemed somewhat unfavorable, we were treated to a very fine exhibition of his powers.

"This evening there were two birds present, and at times we had both in the air together. Once there came a sudden whistling of wings, and we saw one bird chase the other out of this territory. Pursuer and pursued were very plainly visible as they darted and twisted over the tops of the pines on the western border of the cover. Presently one returned and resumed the serenade. I wondered whether this performance was a part of the courtship, or whether my little friend was driving an interloper away from his lady's casement. If the latter was the case, no serious harm seems to have resulted from the combat, if such it was, since we heard what was probably the intruder performing a little distance away a short time after.

"One of my companions carefully timed several of the flights. They ranged from forty-five to fifty-five seconds in duration, divided approximately as follows: first, a period of whistling, circling flight while the bird mounted to his proper height-anywhere between sixty and one hundred yards, as nearly as I could estimate it in the uncertain light-lasting about thirty-five seconds; second, another period of short but somewhat 
varying extent, when he piped a few preparatory notes at little intervals before starting into his full tide of song; third, the song itself, filling perhaps fifteen seconds; and finally, the dart to earth, with wings half closed, made in silence. The intervals between flights ranged between thirty and sixty seconds.

"The song notes were as clear and liquid as a bobolink's, and fully as musical. During the production of these the whistle of the wings could be plainly heard as a sort of accompaniment to the vocalism."

I think no such good description of the woodcock's song has before been given. Many observers mention only a single note, somewhat like the ordinary call of the night hawk, which he continues for some time, and then suddenly pitches downward from his height, and drops into cover. Here the female is waiting for him, and about her he struts, with head thrown back, wings trailing and tail spread, a parody on the turkey cock of the farmyard.* The nest is a rude structure of dead leaves and grass, and is usually placed under a fence, or by a $\log$ in some thick swamp, or perhaps on a tussock or bit of high ground in an alder run. The eggs are generally four in number, and are of a dull cream color, marked with large spots of bright or dull brown.

In No. 2 of Vol IX, of the Bulletin of the Buffalo Society of Natural Sciences, are found "Notes on

\footnotetext{
*Some years ago I contributed to the Century Magazine articles on the woodcock and the snipe, from which, by the courtesy of the Century Company, I am permitted to make extracts for the present chapters on those birds.
} 
the American Woodcock," by Ottomar Reinecke, of Buffalo, N. Y.

Mr. Reinecke-as have many other people familiar with the bird-points out that it is one of the earliest of the birds to nest. Sometimes this early nesting is followed by unhappy consequences, as in cases which took place in the spring of I904. The author says: "In our locality the I 3 th of April is usually the time to look for full sets of woodcock's eggs. That year was no exception to the rule, although at the time referred to we had been visited by a heavy snowfall, which covered the ground to the depth of eight inches. The snow had been partially melted by the sun, but was frozen hard during the ensuing night. Two days later another snow storm occurred. The next morning found us on the ground, which is an ideal locality for the nesting of this bird. The ground was then covered with about five inches of crusted snow. In company with several friends we immediately began our search for the woodcock. We soon found the tracks of a pair where they had been feeding or trying to find food around partly frozen water holes.

"We flushed the birds and began looking the snowcovered ground over carefully for the nest. We found none in that vicinity, but following the tracks of a single bird, which evidently were made the previous day, we came to the spot at least a quarter of a mile distant where the bird had started on its walk to the water holes. On examining the place nothing but a 
slight depression was found, appearing somewhat dirtier than the otherwise clean snow.

"We were beginning to think that the bird had taken this place in a small clump of bushes as a refuge from the snow storms, when it was suggested that perhaps after all the nest might be under the hard frozen snow. This was no sooner suggested than we were down on our knees, taking turns at melting the snow with our breath. After a few minutes we were rewarded by the sight of one egg, and, continuing our efforts, we found a fine set of four eggs, the first lying directly in the middle and on top of the three other eggs and being separated from them by a layer of at least an inch of snow. From this I take it that when the first snow storm came, the bird had laid only three eggs and found difficulty in keeping on them for any great length of time. The woodcock lives on worms from soft, marshy ground, and, consequently, she could not remain a long time on the eggs, or, possibly, the large amount of falling snow made the bird continually shift her position until, by this constant moving, the eggs were covered with snow; then the next day the other egg was deposited as before mentioned. After this the second snowfall occurred, which the bird could not withstand, and so finally deserted nest and eggs. We found several more nests in the same way on that day, and in each case the eggs were found as described."

Mr. Reinecke records the finding in April, I90I, of five eggs in a woodcock's nest on which the bird was 
sketched and from which she was afterward frightened. The number is very unusual, if not previously unexampled.

As soon as the young emerge from the egg, they leave the nest and follow the mother. Thenceforward their development is rapid, and young birds have been found well able to fly by April Io. Two broods are usually reared in the Middle States. A curious habit of the woodcock, which, though well attested, is as yet but little understood, is its practice of carrying its young from place to place, apparently to avoid danger. Exactly how the mother bird does this is not certainly known, but the weight of evidence seems to show that she holds it clasped between her thighs, as a rider does his horse, and does not carry it in her weak and slender claws. She will sometimes thus transport her young for a hundred yards or more, and if pursued will even make a second flight with it.

By the last of July, in favorable seasons, the young of the second hatching are quite fit to look out for themselves, and early in August the woodcock disappear-that is to say, can no longer be found by those who search for them. They retire to the dry hillsides among the heavy undergrowth, and remain there until the moult is complete. From such places-often among thick growths of hazel or witch-hazel-they may sometimes be flushed by the ornithologist who is searching for early migrants. In September they collect once more in their accustomed haunts, and then are fat, in good plumage, and fit for the gun. 


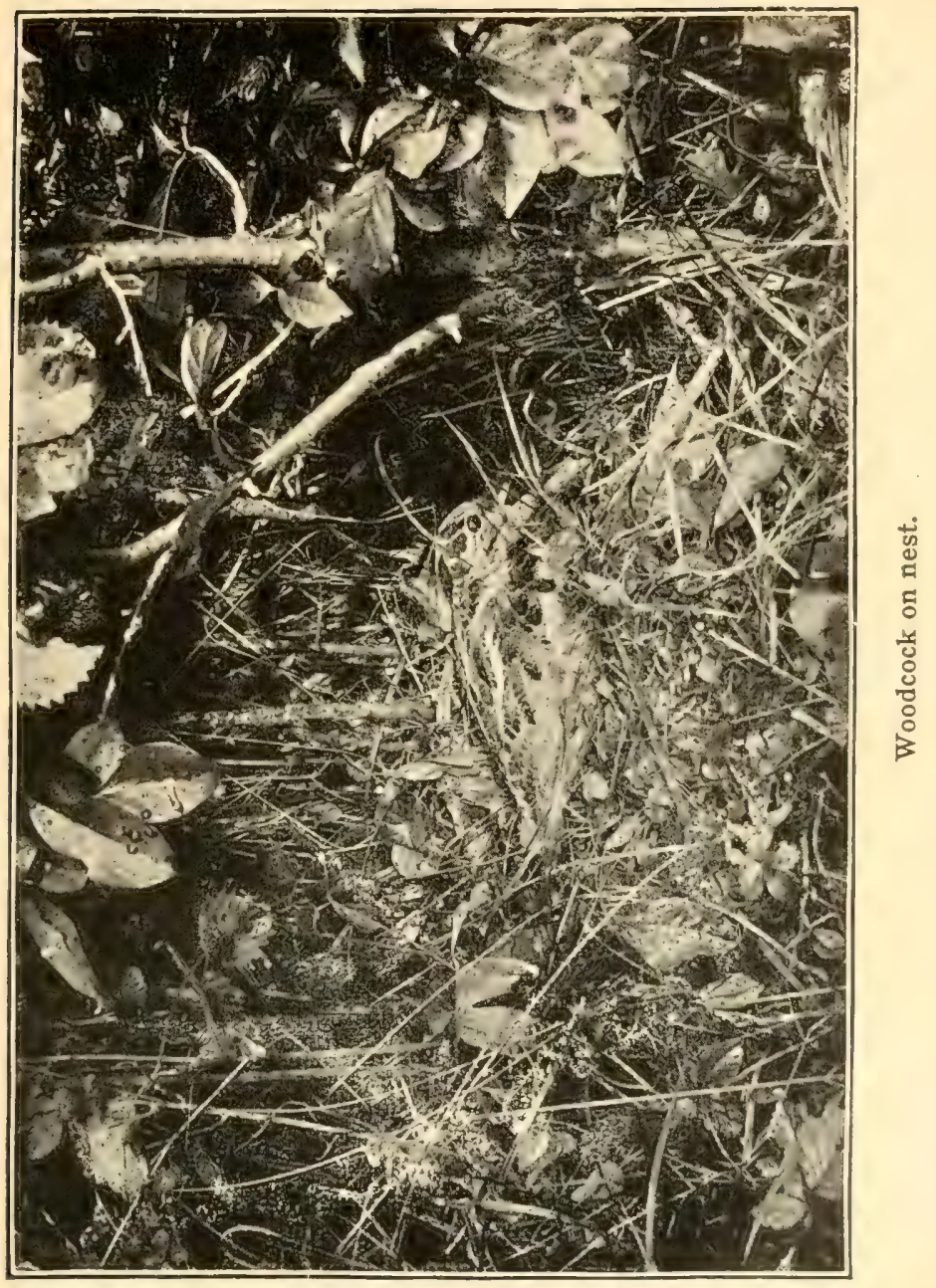



Twenty years ago there was much discussion as to the manner in which the startled woodcock produces the whistling sound usually heard as it springs from the ground. The ranks of sportsmen were divided into two factions, one of which held that the whistle was vocal, while the other was as firmly convinced that it was produced by the wings.

Oddly enough, able ornithologists, who were also sportsmen, were divided on the question-and are probably still divided, for the matter has never been satisfactorily settled. Such distinguished men as William Brewster, of Cambridge, and the late Gurdon Trumbull, of Hartford, whose "Names and Portraits of Birds Which Interest Gunners" will always be remembered, took opposite sides on this question and argued at length about it. The ever-increasing scarcity of the woodcock and consequent inability to observe it put an end to the discussion.

Formerly it was legal all over the country to kill this species during the month of July, at which time many of the young were barely able to fly, and when, after a late spring, some of the mother birds were even still brooding the eggs of their second hatching. This practice was most pernicious and is no longer permitted in most States.

The coming together in September of the birds which have been mysteriously hidden away, no one knows where, is often loosely spoken of as "the first flight" - in other words, is regarded as the beginning of the southward migration. It is, however, nothing 
more than a collecting in favorite food localities of the home-bred birds-those which have spent the summer, or been reared, in the neighborhood.

The first true migratory movement of the woodcock usually follows a sharp frost early in October. The birds are not gregarious, and for the most part move singly; though two, three, and even four have been seen flying together, and sometimes six or eight may be started in succession from a single small piece of cover. The migration is performed during the night, though in dull, cloudy weather there is some movement in the daytime. Their flight is low over the fields. This low flight is swift, and the birds are often killed by flying against telegraph wires, and sometimes dash themselves against buildings.

In New York and New Jersey the woodcock may almost be considered as resident, for in mild winters a few birds are to be found late in December and early in February. The bird does not seem especially to dread the cold, but the freezing up of the ground cuts off the supply of food, and so obliges it to move southward. Often, however, in the coldest weather, an old fat bird may be found about some warm spring hole, where the ground never freezes; and here, if undisturbed, it may remain all through the winter.

The principal food of woodcock is the earth-worm, though they also devour many insects which are to be found in the damp situations which they affect, and have been seen to catch butterflies. The "angleworm," however, is the main reliance of this species, 
and the number of these which a single bird will devour in a given time is astonishing. Audubon says that a woodcock will devour in a single night more than its own weight in worms, and some experiments on this point, made on a captive bird, entirely confirm the observations of the great naturalist. This specimen was apparently a male, and weighed, at the time of its capture, five ounces. His cage was two feet long and one deep, and had been fitted up for him by covering the bottom with long, dry moss, except in one end, where there was a box of wet earth, eight inches square and three deep. The bird was fed altogether on earth-worms, and these were buried, a few at a time, in the mud. From the first this woodcock manifested very little fear of man; and it was but a short time before he so well understood what the opening of his cage door meant, that at the approach of his owner he would run to his "feeding-ground" in anticipation of the meal. So eager was he that it was necessary to push him away to the other end of the cage while the worms were being buried. As soon as he was permitted he would run to the mud and "bore" for the worms. This was a very interesting proceeding. He would push the point of his bill into the earth at an angle of about sixty degrees, and by two or three deliberate thrusts bury it to the base. While doing this the left foot was slightly advanced and the body somewhat inclined forward. When the bill was wholly buried, he stood for a few seconds perfectly still, as if listening. Perhaps he 
was doing so, but it seems more probable that he was waiting to see if he could perceive any movement in the earth near his bill. If none was felt, he would withdraw his probe and thrust it in again a little farther on. If, however, he detected any movement, the beak was hastily withdrawn, rapidly plunged in again in a slightly different direction, and the unfortunate worm was brought to the surface and devoured with evident satisfaction. When the supply of worms was exhausted the bird carefully cleansed the mud from his bill by means of his feet and, after giving himself a shake or two, retired to the farthest corner of his cage, buried his long beak among the feathers of his back and settled himself for a quiet after-dinner nap. Sometimes he would thrust his bill down among the moss once or twice, and then walking to his water dish would wash it by slowly moving his head from side to side. After he had been confined for over a month, the worms fed to the bird during twenty-four consecutive hours were counted and weighed, and he was found to have eaten two hundred worms, weighing five and one-quarter ounces. At the end of this time he was still eager for food. Somewhat later he had increased one ounce in weight, and he now ate in twenty-four hours no less than eight ounces of worms.

For nearly twenty years now the woodcock has been growing more and more scarce, and it has been generally accepted as true that it is on the way to extinction. Not many years ago so distinguished a 
naturalist as Dr. A. K. Fisher published in one of the Year Books of the Department of Agriculture an account of Two Vanishing Birds, one of which was the woodcock. Until within a few years summer shooting of woodcock has been permitted in a number of States, a practice which resulted in the practical destruction of almost all the birds breeding and reared in certain territories. So much shooting at a time when the birds were but recently from the nest and many of them able to fly only short distances, was extremely destructive. The birds were so gentle and at that season fly so easily that summer shooting was really a sport for children rather than for men.

If kept up long enough, this would have resulted in the extermination of the bird over considerable areas, or in such a reduction in its numbers that some natural change, which under ordinary circumstances might be wholly harmless, might almost wipe the bird out of existence. For many years far-seeing persons have recognized this danger and have been laboring faithfully to have the practice of summer shooting stopped. It is only within a comparatively short time that their efforts have been successful.

Besides this danger, to which the woodcock were formerly exposed over much of the country, was another which destroyed them by wholesale, although such destruction came only at very long intervals. This was the occurrence of periods of severe cold in their southern wintering grounds. Though such cold periods do not come often, yet orange growers in 
Florida know to their cost that they do occur at intervals. Frosts which merely chill the ground may prevent the woodcock from feeding and so may force them to congregate at a few open spots or warm spring holes, where if found they can be readily killed, but severe colds long continued are exceedingly destructive.

In February, I899, such a cold wave swept over parts of the South, and its influence on bird life in general was so interesting that I need not apologize for quoting the gist of the observations made by $\mathrm{Mr}$. Arthur T. Wayne, of Mt. Pleasant, S. C. I give this account* of the great cold wave of February I3 and I4, I899, chiefly in his own words, omitting only the technical names of the various species:

"The cold wave which struck the coast of South Carolina was the severest recorded for two hundred years. On Monday, February I3, the thermometer registered $14^{\circ}$ above zero, with the ground covered with snow from four to five inches deep on a level, while drifts were two feet deep. This is a remarkable occurrence for the coast region and to be seen scarcely in a lifetime. On Tuesday, at 6:55 A.M., the thermometer registered $6^{\circ}$ above zero. This exceedingly cold weather came upon us very suddenly. It was sleeting all day Sunday, February I2, but toward midnight grew suddenly colder, and when morning dawned the whole country was covered with snow. The destruction of bird life caused by this cold wave

*Auk, Vol. XVI, I899, p. 197. 
can scarcely be conceived. To say that fox sparrows and snow birds were frozen to death by the millions is not an exaggerated statement, but a conservative one. There was a tremendous migration of fox sparrows on Monday, February I3, following the coast line of the mainland. They apparently came from the northeast in a southwesterly direction. Thousands tarried in my yard all day long and swarmed on the piazza, fowl-yard and other places that would afford protection. They would scratch away the snow in order to find a bare place, singing-that is, the stronger birds - the whole time, while their companions were freezing by the hundreds. IVhile they were numbed by the intense cold, boat-tailed grackles and red-winged bląckbirds would peck them at the base of the skull, killing them and eating them. The stronger fox sparrows would also eat their dead companions. It was a most pathetic sight. I caught quantities of fox sparrows, grass finches, snow birds and chipping sparrows and put them into a large cage, which I brought into the house and placed before a large fire, with the hope of saving them from destruction; but, despite this, they all died. Very few of these birds were emaciated, and the great majority were fat.

"The woodcock arrived in countless thousands. Prior to their arrival I had seen but two birds the entire winter. They were everywhere and were completely bewildered. Tens of thousands were killed by would-be sportsmen, and thousands were frozen to 
death. The great majority were so emaciated that they were practically feathers, and, of course, were unable to withstand the cold. One man killed two hundred pairs in a few hours. I shot a dozen birds. Late Tuesday afternoon I easily caught several birds on the snow and put them into a thawed spot on the edge of a swift-running stream in order that they would not perish, but upon going to the place next morning I found one frozen. These were fearfully emaciated and could scarcely fly. Two birds were killed in Charleston, in Broad Street. It will be many years before this fine bird can establish itself under the most favorable conditions."

Mr. Wayne gives a list of sixteen species which he found frozen to death, among them such hardy birds as the meadow lark and hermit thrush. He goes on to say:

"Bluebirds and pine warblers were decimated. Mocking birds, cardinals, Florida towhees, Carolina wrens and all woodpeckers escaped."

It must take any species many years to recover from a wholesale sweeping off of its individuals, such as took place on this occasion, and if such a destruction of the woodcock took place all along a section of its winter home, as did in South Carolina, it is not strange that this species should have been regarded by naturalists as a vanishing bird.

For many years in Louisiana, and possibly in other portions of the Southern States where the conditions 
are favorable, the woodcock are killed during their winter sojourn by firelighting.

Audubon, in his "Ornithological Biographies," says that in Louisiana the negroes commonly killed woodcock at night by firelighting and striking the birds with a pole or long stick.

A resident of Louisiana described in Forest and Stream one method of this destruction, by which enormous numbers must be killed. He says:

"This bird is migratory in this country and does not breed here at all, yet our State has protected him. If the States of his nativity were to protect him entirely for a few years, in conjunction with the protection afforded by the Southern States, no doubt he would soon become abundant.

"The birds are night feeders. Their favorite feeding grounds are old sedge fields burned off clean, and pasture lands that have been pastured closely, but they can also be found in the cotton, corn and cane fields. They must be hunted on ground that is fairly clean of weeds and grass, else they cannot be seen.

"They are hunted with a torch. The primitive way was a pine torch in an old-fashioned fire basket with a long handle, extra fuel being carried in a sack, but the torch has been superseded by the kerosene lamp. A large lamp is placed in a tin frame with a glass front. The lamp has a strong reflector behind it and should illuminate the ground for fifty feet. It is carried by a man who does no shooting, suspended by a strap around his shoulders and about waist high. Walking 
through the fields, as the light is veered around so as to cover the ground within its range, the woodcock can be seen squatting in his feeding place.

"The darker the night the better; a drizzly night is the best of all. On starlight nights it is not easy to get close enough to kill them with a long cane, which the darkeys frequently use, or even to shoot them with squib loads, but on dark, drizzly nights one can almost catch them with the hands before they become accustomed to the light, which temporarily dazzles them. The birds are usually found in pairs-unless one has been killed-and squatting from three to six feet apart, and not infrequently, if the night be very dark, the hunter can kill both before flight.

"A muzzleloader is preferred on account of the cheapness of the ammunition. The birds are rarely ever shot at more than thirty feet and frequently under ten feet. For this reason squib loads are used. An ordinary charge of black powder is divided into two loads, a wad run down on it, and the charge of No. 8 shot is about what a man can hold between his thumb and fore finger, say fifteen or twenty pellets; more would tear the birds.

"The woodcock rarely spends over sixty to seventy days in Louisiana, but during this period many thousands were killed before the enactment of prohibitory laws, not only by the colored man, but by the whites as well, in the manner mentioned. No doubt your sportsmen critics will denounce the method, and, under any circumstances other than those which actually exist 
in Louisiana, their denunciation would be just, but I opine if these same critics could be transported to Louisiana in the woodcock season they would be surprised to find in how short a time they would become lovers of the night pothunt.

"I know from personal experience. I was born a sportsman and I can recall, some thirty-five years ago, when I scorned to shoot a woodcock on the ground, but then I was new in the State. It did not take me long to get broken in to the method. The great delicacy of the bird and the almost impossibility of getting him by daylight hunting begets the habit of night pothunting, and, like other bad habits, it grows apace.

"This section of the State is rather out of the woodcock country, and I have not hunted them for twentyfive years. They are here every year, but not plentiful enough to warrant night hunting, but well do I remember a noted hunt of about thirty-five years ago. I was a visitor to Louisiana then. One dark, drizzly night my brother-in-law was lamp-carrier for me, and I killed seventy-two from 9 until I A.M. with a muzzleloading gun. No, it was seventy-one that I killed with the gun, but when my anmunition became exhausted on the way home we found a bird on the side of the path. I drew the ramrod and killed it with a blow on the head, making an even six dozen.

"I cannot refrain from telling of my last woodcock hunt. It was in January, I885, just twenty-five years ago. On a starlight night three of us started out for a hunt, one gunner on each side of the light. The 
birds were plentiful, but were so wild that we could not get shots at half of those we found. The two of us killed fourteen.

"The next night was bright also, and I suggested a new scheme. I, being a crack wing shot, was to load my gun with the ordinary bird load, while my companion was to use the squib; he to shoot them on the ground and I to shoot those on the wing when flushed.

"I instructed the light-carrier that when a bird rose for flight he should keep the rays of light on him as he flew. This was easily done by tilting the lamp with the hands. The results of the hunt were twenty-nine; my companion killed fourteen and I killed fifteen, all flying. I do not now recall that I missed a single shot. Several times my companion, shooting at too long range for his squib load, missed, and I killed the bird in the air. But it was not remarkable shooting at all, for when the light was thrown on him he seemed practically to stop in the air. I could almost have killed them with a rifle."

The vast alluvial region of southern Louisiana has many large areas peculiarly favorable to woodcock life. Years ago, before the pothunter had effected so much destruction, the woodcock congregated in those regions in vast numbers in November and December. The heavy tropical rains, of whose volume and persistency the northern resident has little conception, softened vast areas of land, cultivated and uncultivated, and thus fitted them for the feeding grounds of the wood- 


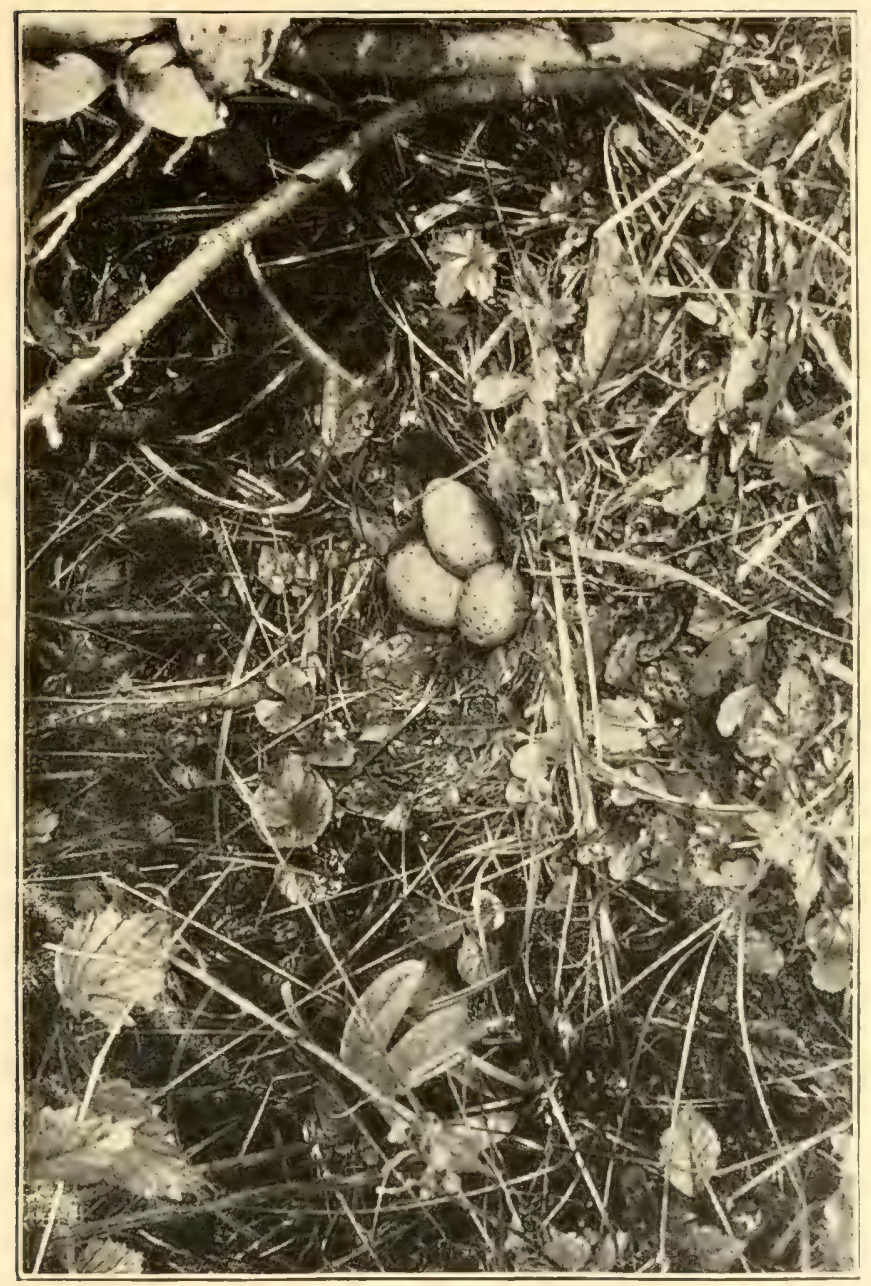

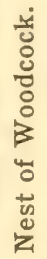



cock. At the same season snipe abounded in enormous numbers, and for the same reason.

Another casual, but purely local, agent of destruction to the woodcock is the forest fires, which burn so frequently in many of the Eastern States and which run through groves or swamps where the woodcock have their nests. In such States as New York, New Jersey, Pennsylvania, Connecticut and Massachusetts, small brush or forest fires started by careless railroad engineers or thoughtless boys, occur in autumn and spring, and these may travel over considerable stretches of country, destroying great numbers of young seedling trees, burning through the leaves, dry underbrush and dead branches of swamps, and destroying the nests of quail, woodcock and ruffed grouse, and sometimes even injuring the birds themselves. These fires, while doing harm here and there, are not of regular occurrence and work but little injury compared with those prairie fires which in old times used to sweep over the fertile States of the IVest, destroying the nests of the prairie chickens, leaving the country bare of food for them and often causing the farmer the loss of some of his haystacks, or even of some of his buildings. Yet the harm done by these eastern fires is a serious matter in a region where game birds are few. An area so burnt over is not likely to be occupied by woodcock for several years. The birds will not breed there, nor, in most cases, will they resort to such a burnt area for food or rest.

The years 1908 and 1909 seem to have shown dur- 
ing the fall migration a greater number of woodcock than have been seen for many years. We have heard of bags being made of fifteen or twenty birds to a gun, and gunners have told us of starting thirty or forty woodcock in a single day. One gunner of great experience and knowledge of the habits of the birds and the particular sections to which they delight to resort, has told us that in the autumn of 1909 he started in a single day by actual count not less than fifty birds. The number that he and a companion killed was somewhat less than one-third this number. They kept within the law of the State in which they were shooting, but the gunner confessed that the temptation to overrun the limit was strong.

The observations which have been carried on as to the present abundance or scarcity of woodcock are not sufficient to justify us in concluding that they are really increasing, but two or three more favorable seasons should make us hope that before long the birds will be back with us again in something like their old-time abundance.

It is certain that of late years in parts of New England birds have bred where they have not been seen for many years before; and under present conditions, when woodcock are killed only in the autumn, they are usually fat, strong-winged birds, very different from the little cheepers of mid-July.

This improved condition of things is no doubt due to the adoption of proper game laws in the British Provinces, New England and the States north of Mary- 
land. In this large area, which includes a considerable portion of the summer range of the woodcock, shooting lasts for from one to two and a half months, beginning from September I5 to November I in different States, and ending November I 5 to January I. The abolition of the barbarous practice of spring and summer shooting and the shortening of the open season has resulted in this encouraging increase in the number of the birds. 


\section{AMERICAN SNIPE.}

\section{Gallinago delicata.}

The snipe is a small bird, not much more than onehalf the weight of a woodcock. Its bill, which is dark brown and considerably swollen at the end, is more than twice as long as the head. The lower portion of the tibia is naked; in other words, the feathers do not come down to the tarsal joint, which they reach in most other birds, and perhaps in all land birds. The eyes are brown, and the feet are bluish or greenish gray. The upper parts are generally black or blackish brown, divided lengthwise by streaks of brown and whitish. The chin is whitish and the neck reddish brown spotted with darker. The scapulars are streaked with reddish brown, as are also the wing coverts and secondaries. The tail feathers are blackish, with a broad band of brownish red near the end, and the tips white. The bird's length is $10^{1 / 2}$ inches, its extent of wings from $I 6$ to $I 7$, and the bill is over $2^{1 / 2}$ inches long, and sometimes longer. As in the woodcock, so in the snipe, the bill is a sensitive organ of touch.

Allied to the woodcock, but wholly different from it in appearance, habits and home, is the American snipe, often wrongly called "English" snipe. Birds 
of this genus are to be found all over the world, and almost everywhere their habits are more or less alike. During their migrations they frequent fresh meadows or wet ground, where the worms and insects which constitute their food are to be found. They are swift of wing, make long journeys, and, for the most part, breed well to the North. It is not, however, the cold which causes them to migrate, but rather the scarcity of food which precedes the advent of cold weather. Many of the snipe along the Atlantic coast migrate to a locality only just below the frost line. Often they may be seen at any time in the winter on the fresh meadows of Virginia and North Carolina, and if cold weather should come and a freeze take place, they move on forty or fifty miles southward, to return again as soon as milder weather has softened their feeding grounds.

The snipe goes southward to the Gulf of Mexico and beyond. As worked out by the American Ornithologists' Union, the range of the snipe is essentially as follows: North America and South America. Breeds from northwestern Alaska, northern Mackenzie, central Keewatin and northern Ungava, south to northern California, southern Colorado, northern Iowa, northern Illinois, Pennsylvania and New Jersey. Winters from northern California, New Mexico, Arkansas and North Carolina, through Central America and West Indies to Columbia and southern Brazil; remains in winter casually and locally north to Washington and Montana, Nebraska, Illinois and Nova Scotia. Accidental 
in Hawaii, Bermuda and Great Britain. Cold affects them little. My friend, Colonel W. D. Pickett, observed snipe wintering in Wyoming, where the mercury often went down to from twenty to thirty degrees below zero. Here, in warm springs that were never frozen, the birds remained and seemed to prosper all through the winter. In the same way mallard ducks winter in open water holes in the interior of Alaska.

Usually the snipe reaches the middle and southern New England States early in the month of April, though this is a matter which depends largely on the weather. Here they loiter for some time, the greater part of them moving on farther to the North, where they breed. Nests have been found in New York State, and in the summer of 1908 I saw in August on the banks of the Housatonic River, in Connecticut, snipe which I believe had been hatched there.

Most of the snipe, however, go as far north as Canada; and New Brunswick, Nova Scotia and suitable localities just north of the boundary line between the United States and the British possessions are favorite breeding grounds.

The nest is usually a hollow in the open marsh, where the moss or grass has been pushed aside and bent down to make a concavity which will hold the four eggs. These, like those of many of this group, are sharply pointed-pyriform-and always lie in the nest with the four small ends together. They are grayish green or olive in color, thickly dotted, blotched and spotted with dark brown, the spots growing larger at 


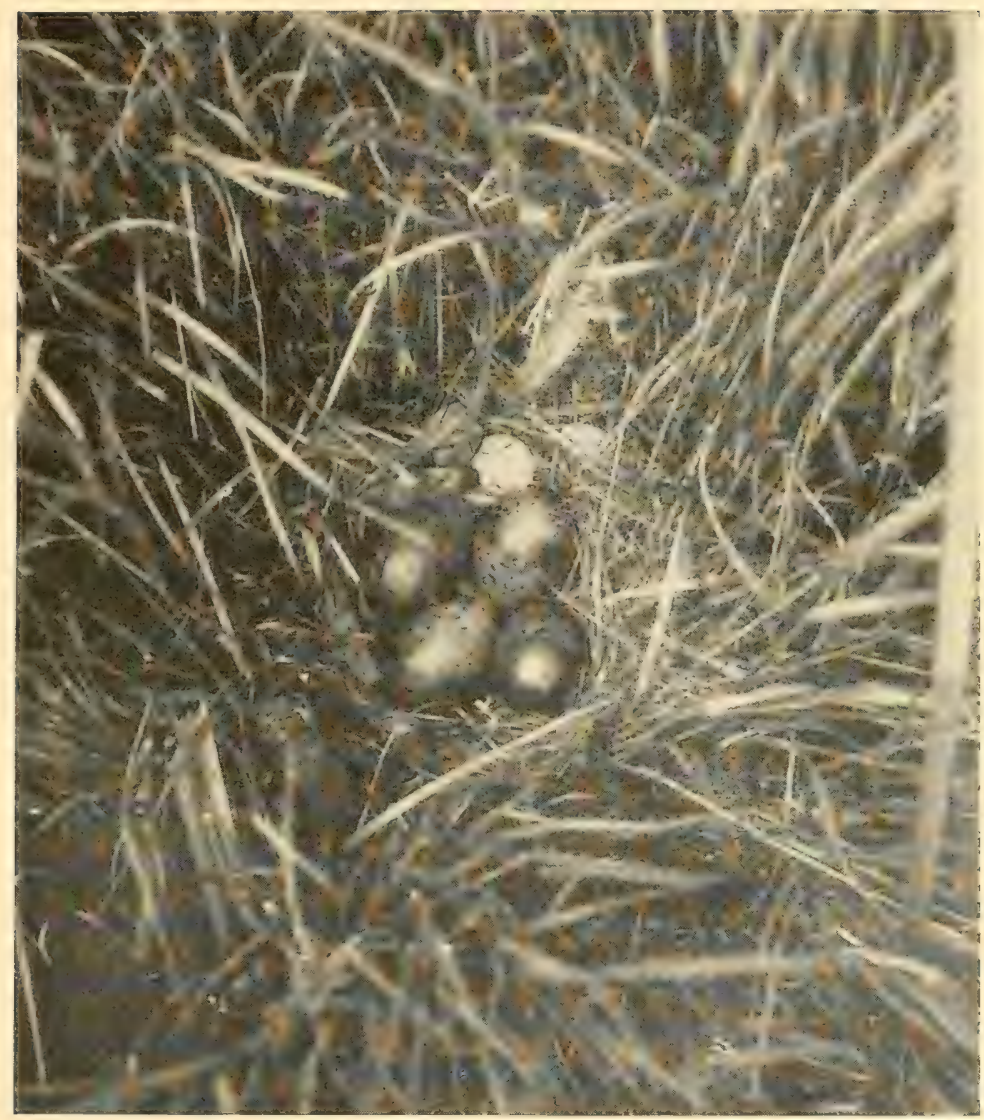

Nest of Wilson's Snipe. 

the large end. They measure more than an inch and a half in length by a little over an inch in breadth. When hatched, the young leave the nest at once. They are tiny little things covered with yellow and brown down. At this age the bill is short, and the young are unable to probe for food. Audubon says that at first they seem to feed on minute insects found on the surface of the mud, or amid grass and moss. It is possible that they do so, but probably no one knows very clearly just how they are nourished for the first few days of their lives; but as they grow older and the bill increases in length and strength, they begin to feed as do the old ones, and probe the mire.

On their return flight the snipe make their appearance quite early and are often found on good ground in small numbers in late August or early September. If the weather has been very dry, so that the area soft enough to admit of their food being procured is contracted, snipe may often be found in considerable numbers on small wet places; but as the autumn flight takes place gradually and slowly, the birds moving on for short distances at a time, they are usually not found in any such numbers as sometimes occur in spring at the height of the migration, when some cold wave checks the onward advance.

It is commonly believed that snipe spend all their time in wet and marshy places, and very likely they do so, when undisturbed. Once, however, many years ago, I visited a snipe ground near Vincennes, Ind., where the birds were astonishingly abundant. We 
killed many, and finally the snipe became wild and flew away, not as if going to great distances, but as if deserting this especial place. In the effort to learn where the birds had gone I passed over a little rise of ground on to a small, cultivated plateau of the prairie running out between two arms of the marsh, and to my great astonishment. started a large number of snipe from the dusty ground between the rows of potatoes. A little later, entering a piece of timber, where the ground was dry under foot, several snipe sprang up in front of me and flew away. It was apparent that these birds, being much harried on the marsh, had taken refuge in this place, waiting until the cause of the disturbance should disappear. I have never seen snipe so abundant anywhere as they were in this place. The following morning, returning to the marsh, very few were found, and those few extremely wild.

The food of the snipe consists chiefly of earth-worms and various insects which are found in the soft mire of the marshes which they frequent.. Similar in its food to the woodcock, its flesh is quite as toothsome, and, indeed, it would be difficult by the taste alone to tell which bird one was eating.

The snipe is commonly called jack snipe, or English snipe, both misnomers, which should not be used by sportsmen. It should properly be called snipe, common snipe, or American snipe. In the South, according to Audubon, the Creoles call it cache-cache, no doubt from its cry, while Mr. Nuttall gives "alewife bird," "from its arrival with the shoals of that fish." Years 
ago I called attention to a parallel name in Connecticut and elsewhere in New England: "As the bird arrives about the same time as the shad and is found on the meadows along the rivers where the nets are hauled, the fishermen, when drawing their nets at night, often start it from its moist resting places, and hear its sharp cry as it flies away through the darkness. They do not know the cause of the sound, and from the association they have dubbed its author the shad spirit."

In the same way, Krider, in his sporting anecdotes, speaks of the snipe as called shad-birds by many of the fishermen along the Delaware.

Until the time of Wilson, the American snipe was regarded as identical with the English snipe, and it is, of course, from this similarity of appearance that one of its common names is derived.

Until within a comparatively short time, the snipe, like many of our wild fowl, has been almost without protection. To be sure, in the Northern States it was not practicable to kill it in winter, but whenever to be found it was fair game for the gunners of all the Northern States. On the other hand, it has always been famous for the twisting flight, which renders it very difficult for inexperienced gunners to kill; yet at times, when the birds are fat, tame and unsuspicious, this difficulty is greatly reduced, and great numbers may be killed.

The coloring of the snipe is markedly protective in character. White below, barred on sides with black, with a breast more or less streaked, and upper parts 
black or gray, longitudinally striped with white, whitish and cream color and tawny, it is extremely difficult to see on the ground. Once, in Montana, riding near a little mud flat, dotted with tussocks of yellow grass, I saw at a little distance a snipe feeding in the mud. For some reason he had not noticed me until I got quite close to him. Then he stopped, looked for a moment, and took two deliberate steps which brought him between me and a yellow tussock, the yellow of which was, of course, constantly interrupted by shadows of darker-the spaces between the blades of grass. Without taking my eye off him I looked at the tussock, and after I had adjusted my field glasses, could make out a snipe standing there in plain sight, but invisible because of his background. After a moment or two the bird seemed to think that it had been needlessly alarmed, and moved out again against a dark background, where it was plainly seen; but when I started my horse forward, it again became alarmed and retreated to its position of shelter, which again was in front of, and not behind, the tussock. It seemed to understand that this background would absolutely conceal it. This is, of course, only one of the common devices of wild animals to escape the observation of their enemies.

The snipe is not likely to be taken for any other one of our game birds, though the dowitcher, or brownback, one of its nearest relatives, resembles it rather closely. Mr. Trumbull, in his admirable book, "Names and Portraits of Birds which Interest Gunners," gives 
the derivation of the old word, dowitch, as being originally "the Dutch or German snipe (Duitsch, Deutscher), probably employed to distinguish the redbreasted snipe from the common 'English' snipe."

In spring and, to a less extent, in fall, the snipe often practice a curious performance, called by some sportsmen booming and by others drumming. The birds, of which there are likely to be a considerable number, rise high in the air, circle more or less about overhead, often uttering a twittering song, and then may suddenly drop from a great height toward the ground, causing a humming or drumming sound, which is believed to result from the air passing rapidly between the quill feathers. An interesting account of this action and, indeed, of several habits of the snipe, was written by Mr. Austen to Forest and Stream, years ago, and commented on by Dr. Nicols, of Cookstown, both these gentlemen residing in Canada. We quote Dr. Nicols' remarks :

"In your issue of April 23, Mr. H. Austen, of Halifax, N. S., claims that the snipe does its booming (I take it he means drumming) with his voice, and not, as supposed, with his wings, and that this noise is only made at dusk or long after dark. If Mr. Austen will go out to any good snipe ground when these birds are in, especially in the early part of May, in the spring, or September or October, in the fall of the year, on a dull, overcast day, he will find numbers of snipe in the air circling and soaring about and drumming to their heart's content, when he will be satisfied-or I am 
much mistaken-that the noise a snipe makes when drumming or booming is made with his wings.

"In the same letter Mr. Austen writes: "All the sound that I have ever heard in the daytime has been their scaipe, except that on August II, I885, when shooting on the marsh, I heard about and around me who, who, who, only not in very loud tones, and for quite a while was puzzled, until I found running about me at my feet three tiny young snipe, which must have been a very late, or, possibly second, brood.' If Mr. Austen will go out where: these snipe breed, during the mating season-that is, with us, in the month of May -he will find that snipe sing, twitter and call. During this season, snipe call one another pete, pete, pete. The cock bird springs into the air, flying twenty or thirty yards before lighting again, with his tail and head up, singing, and twittering much like a bobolink. One could hardly think that these tame, foolish birds were the wild, swift-flying, hard-to-hit birds of the previous month.

"The snipe and woodcock both drum with their wings. Woodcock drum about dusk, letting themselves down from an elevated position plump on to the ground, with wings set edgewise. Snipe generally drum on dark and dull days, letting themselves down from a high position with wings set edgewise, fifty or a hundred feet, immediately soaring up again to circle around as before. This they repeat for hours together. Years ago, when snipe were plentiful in the Holland marshes, a few miles from here, I have seen upon a dull day 
fifty or sixty snipe in the air at one time, circling and drumming; in fact, every snipe on the marsh appeared to be up in the air. I need hardly say that on such occasions the bag was small. In those good old times I remember in the month of October making a bag of I05 snipe in one day; the day was a bright, warm, still day." 


\title{
GALLINACEOUS BIRDS
}

\author{
Galline.
}

Among the gallinaceous birds, also called Gallinccock family - and formerly Rasores, scratchers-are to be found by far the most numerous and economically the most important of the upland game birds. The group includes the turkeys, guinea fowl, pheasants, grouse, partridges, quail and some other groups, wild and domesticated, which are especially used for food. On the one hand it is allied to the pigeons, and on the other to the cranes, and through them to the limicoline birds, which include the snipe, woodcock, plover and so on. The great systematist, Huxley, divided the gallinaceous birds into two groups, one of which he called Alecteropodes, or fowl-footed, in which the hind toe is small, and elevated above the others-as, for example, in the domestic hen, the turkey and the grouse-while to the other division he gave the name Peristeropodes, or pigeon-footed, in which the hind toe is well developed and long, and all four toes are in the same plane and rest equally upon a flat surface in walking-as the pigeons, currassows and others.

The English naturalists consider all the gallinaceous game birds which we know here in northern North 
America, as well as a number of others, to belong to the pheasant family (Phasianida) which in that view includes the turkeys, the pheasants, the partridges, the grouse and some others. Until recently American naturalists were disposed to regard the pheasant family as limited to the true pheasants, the turkeys, domestic fowl and guinea fowl; and to place the grouse and the partridges and quail in a family by themselves (Tetraonide), the grouse family. For the partridges of the Old World the sub-family Perdicince was established, and another sub-family (Odontophorince) for the quails of the New World. By American ornithologists these two groups have recently been given family instead of sub-family rank, and are called Perdicide and Odontophoride. The turkeys have also been given family rank, and are now called Meleagride.

Although the various birds belonging to this group may differ widely in many respects, all have certain characteristics in common. In all the body is heavy and round, owing to the great development of the pectoral muscles-what we call the breast in a bird-the head is small and the neck rather long. The bill is short and stout, much arched, and overhangs the lower mandible.

The digestive system has certain peculiarities correlated with their habits of life. There is a large crop capable of great distention; a strong gizzard-except in the sage grouse-lined with a tough, almost horny, coating, peculiarly adapted to grinding the hard sub- 
stances, as grain, nuts, and seeds, on which the birds very largely feed.

The wings are generally short and rounded, and the flight, while often extremely swift, is more or less heavy and labored and seldom greatly protracted. In some species certain feathers of the wing are enormously developed.

The tail varies extremely. In some species it is very long and pointed, in others extremely short; again narrow but long, or less long and very wide. In the peacock, one of the large and showy pheasants, the coverts of the tail greatly exceed the quills in length. In the domestic fowl the tail develops a number of oddities. In the blackcock the quills on the outer sides are curiously bent outward, whence one of its names, Lyrurus -lyre-tailed.

In the grouse and the partridges, the metatarsus, that portion of the "leg" which is without the body, and which in most birds is not covered with feathers but scales, is short, whereas in such birds as the turkey or the pheasant it is relatively much longer. This so-called leg is really a part of the bird's foot, and corresponds to that part of the foot in man which lies between the ankle and the toes, and in the horse to that portion which lies between the hock and the pastern-the cannon bone.

In the pheasants, quails and partridges the feet are naked, but in the grouse they are always more or less protected by a covering of hairlike feathers, not unlike those found on the feet of certain hawks and owls. 
Sometimes these feathers descend only as far as the toes, but in the ptarmigan (Lagopus-harefoot) the whole foot is thickly covered with dense hairlike feathers, which serve to protect it from cold and no doubt to some extent facilitate progression over soft snow. In the grouse, too, the toes are pectinated-provided with a horny comblike structure-on either side, and these are the only members of the group that are so provided. In some species, if not in all, these pectinations are deciduous. Spurs with a bony core and a horny sheath, thus resembling the horn of a cow-such as we see in the turkey and the male of the domestic fowlare common to all the male pheasants. In some species there are two or more spurs on each foot and in some, spurs are present in the female. They are not found in the grouse or the partridges.

In the grouse family a little tuft of projecting feathers runs forward on each side of the bill and covers the nostrils. In the partridges the nostril is naked, but is protected by a scale which overhangs it.

In the gallinaceous birds the plumage is as varied as it is possible to conceive, ranging from the most brilliant metallic sheens of all hues in some of the pheasants, to the plainest, dullest clay color in some partridges and grouse, as the sage grouse, or the whitetailed ptarmigan in summer plumage. Many of the American quails are singularly beautiful birds, but less by the brilliancy of their colors than by the fine contrasts or harmonies which their plumage exhibits. Of all these birds in America, however, only the gorgeous 
ocellated turkey of Yucatan and Guatemala can compare in brilliancy with many of the pheasants of Asia.

Grouse inhabiting arctic or alpine countries-called ptarmigan-are notable for their seasonal changes of plumage. They turn white in winter and are said to be in a continuous state of moult at all seasons, except for a brief period when they have assumed their summer dress, and again in winter after the completing of the winter plumage. An exception to this rule is the Scotch grouse, which does not turn white in winter, presumably having lost that protective adaptation, because such a change of coloring is not required in the region which it inhabits.

The birds of this group are all formed for life upon the ground, in this respect contrasting markedly with that other division of gallinaceous birds, the so-called pigeon-footed group, which shows a tendency toward life in trees. This, of course, does not mean that fowlfooted birds necessarily avoid trees, for as a matter of fact many of them commonly roost in trees, and all resort to them for refuge and often for feeding purposes.

In many of the pheasants and in all the grouse there are patches of naked skin on the body, which are usually particularly obvious during the breeding season. The comb and the wattles of the domestic hen offer examples of such naked patches. The turkey, of course, has the head entirely naked, covered with roughnesses and caruncles, with a notable process on the forehead. The grouse of North America have narrow, naked patches over the eyes, which during the breeding season 
become congested and large, and by popular writers are sometimes called combs. Besides, several American grouse, such as the sage hen, the pinnated grouse and the dusky grouse, have on the sides of the neck naked patches of skin, which in the breeding season are capable of being inflated, and when so inflated completely change the appearance of the bird. In the prairie chicken, these, when inflated, have been compared to small oranges; in the sage grouse they are much larger; while in the dusky grouse they appear smaller, and can only just be seen through the white feathers which surround them. The sharptail grouse has a naked place in the same position on the neck, and so has the ruffed grouse.

All the grouse have peculiar and noisy methods of ushering in the breeding season, of which the drumming of the ruffed grouse, the booming of the prairie chicken, the hooting of the blue grouse and the dancing of the sharptail are familiar examples. These various actions and sounds are not, however, exclusively confined to the breeding season.

Grouse are generally supposed to be polygamous, but not all species are so. The quails, or American partriclges, are monogamous, the male and female remaining together during the season of incubation and hatching. In fact, in case of accident to the female, the male sometimes hatches out and rears the brood. The American quails possess shrill and rather pleasing voices, while the calls of the grouse are often rough, hoarse and disagreeable. 
46 AMERICAN GAME BIRD SHOOTING

In the north and in temperate regions America is well provided with grouse, and in the south with quails. The American quails reach their greatest development toward the tropics. 


\section{THE AMERICAN QUAIL.}

\section{Odontophorida.}

Of true partridges belonging to that family of gallinaceous birds known as Perdicidce there are none in America, but their place is taken by another family, known as Odontophorida, which has a wide distribution, with a number of species in the United States, and a still greater expansion to the southward.

While the grouse are all large birds, some of them approaching the wild turkey in size, the American partridges, or quails as they are commonly called, are all small. The grouse have the lower legs and feet more or less covered with hairlike feathers, and the nostrils also covered with points of feathers reaching out on to the bill, known as antiæ. The grouse have over the eye a naked strip of skin which in the breeding season becomes to some extent enlarged and congested, so that it is sometimes loosely spoken of as a comb, though it is not a comb like that of the common hen. The American partridges on the other hand have the feet and nostrils naked, lack the bare skin above the eye and usually have short tails. The character which distinguishes them from the partridges of the Old World (Perdicidc) is found in the cutting edge of the mandible, which is toothed or notched. Sometimes this char- 
acter is so faintly marked as hardly to be noticed, and when this is the case it is not easy to point out any distinctive character separating them from the Old World group. The division, however, is a convenient one, and the New World birds are sufficiently alike to be grouped together.

Though most numerous in tropical America, a number of beautiful species are found within the United States. Such are the plumed quail of the California mountains, the helmeted birds of the California lowlands and of the interior, the scaled quail of the southwest and the Massena, or Mearns, quail.

In the United States and Mexico there are ten genera with forty species and sub-species belonging to the Odontophorida. No members of the group range north of the United States, except that the valley quail of California has been introduced on Vancouver Island, B. C., and that formerly the Virginia quail was found in small numbers in southwestern Ontario. 


\title{
QUAIL, BOBWHITE, PARTRIDGE.
}

\author{
Colinus virginianus, \\ Colinus virginianus floridanus, \\ Colinus virginianus texanus.
}

Of all these forms, by far the best known is the bobwhite-the partridge of the Southern States, and quail of the north. It has been divided by naturalists into several sub-species or geographical races inhabiting southern New England and the Middle States, the Southern States, Florida and Cuba, Texas and southern Arizona; and in Mexico are found many other different forms of the genus. All these, except those of the extreme southwest-Mexico-differ from each other chiefly in size and in the varying intensity of the blacks and browns which mark their plumage. Of those of the United States the northern form, known as the quail or Virginia partridge, is the largest; the southern races, called the Florida bobwhite, the smallest and blackest; while the Texas bobwhite is midway between the two in size, and in color is paler and grayer than either.

The general color of the typical bobwhite is reddish brown, paler below and streaked, spotted or crossed with black markings. The lower breast and belly become whitish, and all the upper parts are crossed with 
fine lines of blackish or dusky. In the male, the throat and a broad line over the eye are white, the rest of the head black or blackish streaked with brown. The sides of the neck are spotted with triangular dots of black and white, the back is reddish brown mottled with gray and more or less streaked with tawny. The female is paler than the male, and has the throat patch and the

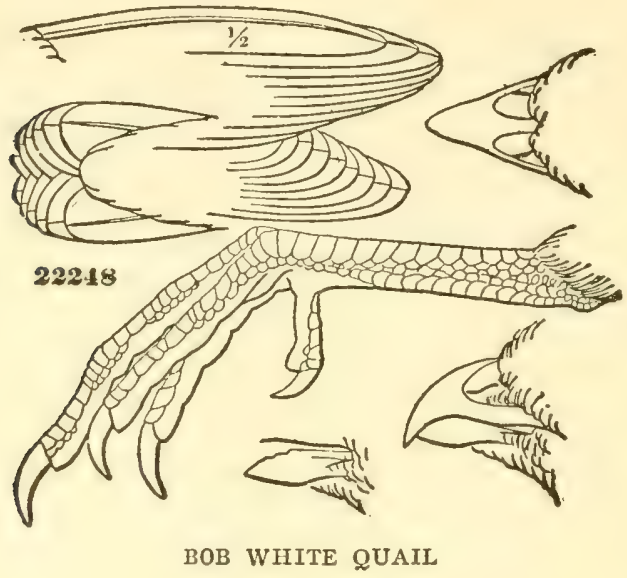

stripe over the eye buffy. Sometimes the young males have this buff throat patch and superciliary stripe. The tail is bluish gray, the under tail coverts white streaked with reddish brown. The feathers of the flanks and sides are reddish brown, striped with whitish. Length about ten inches and wing about four and a half. Extent of wings fifteen to sixteen inches. Weight from about six and a half to eight ounces. 
The Florida bobwhite (C. virginianus floridanus) averages somewhat smaller and considerably darker, the black markings being wider and occupying relatively more space on the feathers.

The Texan bobwhite ( $C$. virginianus texamus) is slightly smaller than the typical bobwhite, but larger than that of Florida. Mr. Ridgway says an olive grayish tint prevails over the whole back without conspicuous black spots, and the general surface is usually distinctly barred with lighter; the black markings of the lower parts are usually broad and nearly transverse, as in $C$. virginiamus floridanus.

Bobwhite is the most widely distributed of our gallinaceous birds except perhaps the turkey and the ruffed grouse. In one form or another it is found from Massachusets south to Florida and the Gulf of Mexico, and from southern Ontario, Canada, west and south through eastern Minnesota, Southern Dakota, Nebraska, Kansas. Oklahoma and Texas, into Mexico. Besides, it has been introduced at various points west of its natural range and apparently has hecome thoroughly established in Utah and Idaho. It is reported also to be quite abundant in portions of California and in the Willamette Valley, Oregon, as well as on certain islands of Puget Sound, Washington. Though introduced and doing well at various points-Denver, Fort Collins, etc. - in Colorado, some naturalists helieve that it has of itself advanced west with the farmers into eastern Colorado. 
Being a bird that lives on the ground, bobwhite cannot survive in a country of deep snows. Along the northern border of its range it has often been almost exterminated in certain regions, because a heavy snowfall during the night has covered up the roosting birds, and then a change in the weather melting the surface of the snow has been followed by another change to freezing, forming a hard crust through which the quail cannot break, resulting in starvation and death. There are many records of bevies being found after the snow of some severe storm has melted, close huddled together precisely as they roosted. Long continued periods of severe weather, when the ground is covered with snow and ice, sometimes make food exceedingly hard to obtain and at the same time render the birds more visible to their many enemies.

At the present time the quail may be said to be almost extinct in Massachusetts, Connecticut and much of New York State, and in many sections they seem to be constantly growing fewer in numbers. This is due largely to over-shooting, but partly also to the destruction of the covers which once afforded them so much more protection than at present. The reduction in their numbers is a misfortune not merely to the sportsman, but to the whole country, for investigations have shown the quail to be a valuable ally to the farmer, destroying multitudes of harmful insects, and also devouring vast quantities of noxious weed seeds. The value of the services which it performs is now coming to be understood by the public at large, and it is reported that in certain 
sections of the country - as in parts of Oklahoma-farmers refuse to permit gunners to venture on their premises in pursuit of bobwhite.

The quail does not migrate and therefore is always exposed to the dangers of winter, and where they have once been exterminated efforts to replace them by other quail imported from the south have seldom been successful. The most hopeful indication for the protection of the species is in the growing comprehension of its economic value. Quail are extremely prolific, and under ordinary conditions might survive the attacks of all natural enemies, but when the climate sweeps off all the bircls in a particular region the progress of re-establishment is slow.

In old times in the south the practice of netting quail was very generally indulged in. Powder and shot were costly, while the net could be used over and over again. This method of taking them, at first practiced only as a means of procuring food, was carried on later for the purpose of securing living birds to sell to persons who desired to restock their covers with quail. Presumably it has been in vogue up to within a short time, if not now practiced in parts of Oklahoma and in Texas.

A chief danger to the quail of the south is the nonenforcement of the game laws, and the market shooting by negroes, many of whom gun persistently almost the whole year round and are excellent shots.

The ordinary bobwhite is the northernmost and best known species of this genus. Yet the smaller, darker quail of the south and of Florida and the grayer form 
of Texas are at once recognized by northern gunners as essentially the same bird that they know at home in the north. The uneducated birds of the southwest, however, do not afford the same sport furnished by birds frequently pursued, but show the disposition to run before the dog exhibited by the other quail of the dry country-Gambel's, the scaled and the valley quails.

It is said of bobwhite that years ago it was scarcely found west of the Missouri River, but that it has followed the settlements north in Minnesota and west in Nebraska. This may be true, but it is quite as likely that it has always existed in this region, but was not observed there until the country became more or less thickly settled.

Wherever found, the quail is resident and breeds. Although occasionally large flocks occur, consisting of twenty-five or thirty birds, it never packs, as do many of the grouse of the open, and where such large flocks are found it is probable that they consist of the first and second broods of the same parents, or of the birds hatched by two hen quail that have occupied the same nest.

1. It must be said, however, that there are at least two records where packs of quail have been seen by good sportsmen of great experience. One of these was Edmund Orgill, who made the following interesting report:

"A curious experience occurred a short time ago to a friend of mine who went on a hunt to north Mississippi, where he had been earlier in the season and found 
birds plentiful. He was accompanied by his brother, and they had a brace of good dogs. They hunted for hours without the sign of a bird, and could not account for the apparent scarcity. At last their dogs made game, but before they could establish a point the birds commenced getting up all around and in front of them. They were confident that there were from 70 to IOO birds, and instead of their taking the usual quail flight, they rose clear up in the air like a flock of pigeons, and went away for half a mile. They followed the line, which was in an open country, and found a few scattered birds in an old cotton field, fully the distance named from where the birds took their flight. They gave up finding more, and started again; and after a prolonged tramp they had a duplicate of their first experience, finding a second flock or drove-not a bevy, for they say there were nearly a hundred. Like the former they made an immense flight.

"Now, I know that it is common for the grouse in Scotland to pack, occasionally the English partridges do, and our prairie chickens; but I never saw or heard of quail doing so before."

On this report S. T. Hammond, referring to the year I 852 , commented as follows :

"In Iowa thirty-eight years ago, when crossing through a piece of woods from one prairie to another, we came upon a clearing of two or three acres of wheat stubble, and a large drove of quail got up, at least 200 or 300 , but they scattered in every direction. To this day we can see that clearing and how the quail filled 
the air. This is the only thing that has come under our personal observation that looked like the Mississippi case."

The quail is a bird of the open, building its nest in the fields, in little patches of brush, or in fence corners, but after the broods are grown, commonly taking refuge when alarmed in woods or tangled brushy patches. Usually the winter home of the bevy is in some swamp or woodland adjacent to fields where grain or weed seeds or other food is accessible, and a few years ago their wanderings were limited to a comparatively small area. The birds went to their feeding grounds in the morning, walking from them to some place where they sat in the sun and dusted for two or three hours; toward night they fed again; and then often walked in among high grass, where they roosted. Of late years, since they have been so constantly pursued, their habits appear to have undergone some change, and they are believed often to roost in the woods or swamps, but in old times it was common to find these roosting places out among the stubbles or in the open fields. Years ago, a gunner familiar with a certain section of country, who had traveled over it enough to learn where the different bevies of quail lived, could almost certainly start each one of them and have a couple of shots before they took refuge in swamp or woods. In those days, however, a man who had such knowledge-if he went shooting frequently-usually contented himself with three or four birds a day. If his 
outings came but seldom, he was likely to demand more and to follow up the bevies.

The broods of quail which have kept together all through the winter usually break up as warm weather approaches, and soon after this comes the mating. This takes place earlier in the south, and in New England it is often the first of June before the birds are mated and the clear whistle of the male is heard. The nest is a depression in the ground, lined to some extent with bits of grass and weed stems and occasionally with a feather or two dropped from the mother's breast. Rarely the parents build over the nest a dome-shaped roof. Captain Bendire quotes Judge John M. Clark of Saybrook, Conn., who saw a male bobwhite engaged in the work of constructing a domed nest. Judge Clark says :

"In May, I887, while on a hill back of my house one morning I heard a quail whistle, but the note, which was continually repeated, had a smothered sound. Tracking the notes to their source I found a male bobwhite building a nest in a little patch of dewberry vines. He was busy carrying in the grasses and weaving a roof as well as whistling at his work. The dome was very expertly fashioned and fitted into its place without changing the surroundings, so that I believe I would never have observed it had he kept quiet."

Captain Bendire also says that Mr. G. E. Beyer of New Orleans, La., found a nest constructed of pine needles, arched over and the entrance probably a foot or more from the nest proper. Such constructions are very unusual. The only concealment commonly found is that 
offered by the weeds and grass that grow about the nest. Captain Bendire says that in the south, cotton rows are a favorite nesting place.

It rarely happens that for some reason or other a second brood of quail may be very late. Such a case was mentioned in Forest and Strcam in February, I879, where a quail's nest is stated to have been found in the month of January.

From twelve to eighteen white eggs are laid. Sometimes many more are found in a nest. In such cases it is probable that two hens have shared a single nest. Captain Bendire tells of a nest of nine eggs taken in Texas, all of which were more or less spotted and streaked with reddish brown and lilac markings, especially about the larger end.

While the hen is sitting on her eggs, the male from some elevated perch not far off whistles through much of the day the cheerful notes which give him his name and which are also interpreted as more wet. When one is near the bird, a third note is heard preceding the two most striking ones, and much lower pitched, making the whole call seem more like ah bobwhite. It is generally supposed that this call is peculiar to the male, but the female also utters it, though not with the same fullness and vigor as the male. On one occasion while driving slowly along a narrow grassy lane I heard a ruail whistling at some distance ahead of the horse. We drew nearer and nearer, yet the sound seemed hardly strong enough for that of a full-grown male, and presently I distinctly saw whistling, a female quail, 
which did not leave her perch on a fence post until the horse had passed her and I was within four or five feet of her. Then she dropped down into the grass close to the fence.

The rallying cry uttered by members of a scattered bevy is a call of three notes, but entirely different from the mating cry bobwhite.

I believe the male bobwhite usually takes part in the work of incubation, and all writers are agreed that if an accident happens to the female, the male incubates the eggs and rears the young. When the eggs hatch, the little ones, then scarcely larger than bumble-bees, at once follow the parents, who look after them with every manifestation of affection. Sometimes it happens that the farmer while driving his mowing machine through the tall grass, may see a male and a female quail rise in front of him and flying but a few feet drop down again. He knows then that somewhere in the grass near his team are the tiny young whose lives are now in jeopardy, and often he will turn his horses about and go the other way, in order to give the parent birds an opportunity to lead their young away from the danger spot. Sometimes the little ones may be seen, a dozen of them, hurrying after their parents across the newly shorn grass, half hidden by its short stems. Often the parents strive to lure man or dog away from the tender young by feigning injury, and on a signal from the mother the young lie close hidden until the danger is passed. 
During their earliest youth the young quail feed almost exclusively on soft insect food, but as they grow larger they eat more and more seeds, and when autumn comes, fruit of one kind and another and grain. In New Jersey barrens, where grain fields are few and far between, I have taken quail that seemed to have fed exclusively on the acorns of the scrub oak.

Most carnivorous reptiles, birds and mammals are enemies to quail, and yet against the mammals and reptiles they are fairly well able to protect themselves. Occasionally a snake devours the eggs in a nest or may destroy a few of the very small young, but the depredations they commit are slight. Hawks are the enemies from which the quail have most to fear, and of these the goshawk, Cooper's hawk and sharp-shinned hawk are the most destructive. I have more than once seen a marsh hawk stoop at a quail, but I never saw this hawk catch one. I have also seen a marsh hawk stoop at a crow, and even at a great sage grouse that would weigh many times what the hawk weighed. The grouse seemed alarmed and ran away, but the crow merely threatened the hawk with its beak and seemed not at all disturbed. 


\section{MASKED BOBWHITE.}

\section{Colinus ridgwayi.}

The masked bobwhite is very little larger than the Virginia bobwhite. It has the whole under side of the head black and the white stripe over the eye is very narrow or sometimes disappears entirely. The neck and chest below the black throat is uniformly cinnamon or reddish, like the other lower parts. The female is almost exactly like the female of the Texas bobwhite, but usually has a strong band of cinnamon color across the upper part of the chest.

There are no special differences in habit among the various forms of bobwhite quail, except those which depend on their surroundings-the character of the country which they inluabit. The masked bolowhite, or Ridgway's quail, was described by Mr. Brewster from specimens sent on from Mexico by F. Stevens. Previous to that, however, Herbert Brown of Tucson, Arizona, had sent on specimens which were erroneously identified as Grayson's bobwhite, a Mexican species not known to occur in the United States.

In a paper entitled "Arizona Quail Notes," published in Forest and Stream in 1885, Mr. Brown writes about this species in the following words: 
"The masked bobwhite is found in the country lying between the Barboquivari Range in Arizona and the Gulf coast in Sonora, more especially between Barboquivari and the Plomoso, where this species is quite abundant. They are also found on the Sonoita Creek, about 60 miles north of the Sonora line. From the Sonoita Valley they range in a westerly direction fully Ioo miles, and through a strip of country not less than 30 miles in width within Arizona Territory. Very probably they may go beyond this, both to the east and west. The habits of the masked bobwhite, so far as we know them, appear to resemble very closely those of the common quail, only slightly modified by the conditions of their environment. They utter the characteristic call of bobwhite with bold, full notes, and perch on rocks or bushes while calling. They do not appear to be a mountain bird, but live on the mesas (tablelands), in the valleys, and possibly in the foothills.

"The masked bobwhite was, three years since, abundant in the neighborhood of Bolle's Well, a stage station on the Quijotoa Road, near the northern end of the Barboquivari Range, 29 miles southwest of Tucson and about 40 miles north of the Mexican boundary line. As the station was then comparatively new, the grass thereabouts was high, and these quail could be had for the taking; but now that the stock has eaten away the grass, the birds have not for a year or more been seen about the place. On the road from Bolle's Well, west to the Coyote Range (about 25 miles), these quail were frequently to be met with, but the teamsters 
and travelers have killed or frightened them off. One of the former assured me that he had killed as many as five at one shot. Ten miles south of Bolle's, in the Altar Valley, we came across a small covey, perhaps a dozen in all. The bright, deep chestnut breast plumage of the males looked red in the sun, and gave the birds a most magnificent appearance. We secured but one, a male, the rest secreting themselves in the tall sacaton grass, which at this point was between 4 and 5 feet high, and as we had no dog we did not follow them. Our next place to find them was on the mesa, southeast of the peak, where we camped to hunt for them, but they were scarce here, and we managed to secure but few.

"In addition to their bobwhite they have a second call of hoo-we, articulated and as clean-cut as their bobwhite. This call of hoo-we they used when scattered, and more especially when separated toward nightfall. At this hour I noted that although they occasionally called bobwhite, they never repeated the first syllable, as in the day time they now and then attempted to do. In body they are plumpness itself; in this respect, considering size, they overmatch the Arizona quail (Callipepla gambeli), with which I compared them. In actual size of body, however, the latter is the larger. Of three stomachs of this species examined, one contained a species of mustard seed, a few chaparral berries, and some six or eight beetles and other insects, ranging in length from a half incl down 
to the size of a pinhead. The second was similarly provided, but contained, in lieu of mustard seed, a grasshopper fully an inch in length. These two were taken on the mesa. The third, from a bird taken in the valley, contained about twenty medium-sized red ants, several crescent-shaped seeds, and a large number of small, fleshy green leaves."

Mr. Brown pointed out, years ago, that the introduction of live-stock into southern Arizona bade fair to exterminate the masked bobwhite in that territory, by the destruction of its nests and eggs by horses and cattle, as well as by the eating of the cover among which it lives. His prediction has been verified, and as recently as June, I909, he wrote, saying: "Colinus ridgruayi is a dead bird so far as Arizona is, as yet, concerned, but it is again getting a good foothold in Sonora, about 75 miles south of the line. I am almost afraid to say anything about it, however, as I fear I might send skin hunters into the country."

Other writers have noted in our common bobwhite the same tendency to disappear in sections where general farming has given place to stock-raising.

The bobwhite family attains its greatest development in Mexico. Though differing greatly in color, the pattern of that color is somewhat similar in all the different forms. Several are black, or black mottled with white, on the breast and tail, where our bird is pale in color, just freckled with black. All have the same whistle with which we are so familiar in our own bird, 
and generally their habits are much alike. They range from the sea-level to an altitude of 7,500 feet.

They have not the shyness or swiftness of wing of the much hunted form of the East and South, and are gentle, unsuspicious little birds, ready to run along on the ground before the traveler or to dodge out of the trail to one side.

Of the dozen forms described from Mexico, perhaps only two, Ridgway's bobwhite and the Texas bobwhite, cross the boundary into United States territory. No one is so familiar with this group in Mexico as Mr. E. W. Nelson, the distinguished naturalist, whose work in various branches of science, in Alaska, Mexico and Central America, is so well known. In the Auk, for April, I898, he published a charming account of this group, which is accompanied by an excellent plate of Godman's bobwhite, a species described by Mr. Nelson, from the lowlands of southern Vera Cruz. Mr. Nelson calls his sketch "With Bobwhite in Mexico," and we copy it here:

"While traveling in Mexico a few seasons ago, I arrived at a small town near the southern end of the tableland in the State of Puebla. The first business in hand was to secure suitable quarters for myself and assistant. Having accomplished this, I was ready at an early hour the following morning for a tramp into the surrounding country. It chanced to be market day, and passing the outskirts of the town I met a straggling procession of Indians, in picturesque costumes, some driving heavily loaded donkeys, others car- 
rying on their own backs crates of fruits, vegetables, hand-made pottery and other simple wares. All were pushing forward, eager to take part in the keenly relished pleasures of petty chaffering, which would enable them to return home with a few decimos knotted in the ends of their sashes. Some of the men saluted me with a polite 'Buenos dias, señor', but I noted that their conversation was carried on in the Aztec tongue, as spoken by their fathers centuries ago.

"Once free of the last houses, a convenient opening in the fence was soon found, and I crossed into a great field, which reached for miles down the broad, open valley. Areas covered with wheat and corn stubble indicated the character of the last crops, while farther away broad belts of brilliant green sugar-cane were in vivid contrast to the dry browns and yellows of the general surface. The sun was shining brightly, and the fresh, balmy air seemed full of life-giving power. The musical notes of meadow-larks were heard at intervals, and on one side of the valley flocks of redwinged blackbirds were swirling back and forth over some small marshy spots grown up with tules. Through the valley bottom flowed a little stream of clear, sparkling water, which, before reaching the distant shore of the Pacific, runs a wild course through the mountain gorges of Guerrero. Behind me arose the mysterious pyramid of Cholula, crowned by a white-walled chapel, which now occupies the place of ancient sacrifice. Over to my right stood the gigantic form of the Smoking Mountain-hoary old Popocatepetl-with the gleaming 
robe of the White Lady-Iztaccihuat1-shining over his shoulder. In front a sweeping plain descended for many miles, through a district of great sugar estates, to the far horizon, where it was walled in by the blue front of distant mountains.

"Turning to one side, I approached some scrubby bushes which appeared to offer shelter for birds or other game. Suddenly the familiar accents of my mother tongue fell on my ear. I listened with bated breath. Again arose in clear, round tones, the calls so familiar in my boyhood days, bobwhite, bobrwhite. With eager steps I hastened forward to a small group of acacias, and there, quietly perched on top of a bush, was an old friend, the author of the notes. It is diffcult to describe the mingled pleasure and exultation caused by this unexpected meeting. It proved to be the Puebla bobwhite (Colinus graysoni nigripectus, Nelson), and during the following days a number of others were seen, and it became evident that my friend of the first morning was one of a colony located in the neighborhood.

"Afterward, during my Mexican travels, I learned that the bobwhites are widely spread in that country, and although many of them have changed the color of their dress more or less, yet their customs and tricks of speech remain much the same as in their northern home.

"At a later date during this same season, while working down the eastern slope of the Cordillera in Vera Cruz, near the city of Orizaba, we found others of the 
family, known as the black-breasted bobwhite (Colinus pectoralis, Gould). They were living in brush-grown and weedy old fields-sometimes straying about the coffee plantations-and were on friendly terms with most of their tropical neighbors. Fortunately, in these parts guns and dogs are few, and mostly harmless, so that Bob's days were generally peaceful and contented. But even here life was not without its cares, for the spotted tiger-cats and woolly-haired opossums, with sad lack of consideration, were given to nocturnal raids that filled them with terror and sometimes lessened their numbers.

"From Orizaba our wanderings led far away over plains and mountains to the city of Tehuantepec, on the hot lowlands bordering the Pacific coast. There we found our friends again, but known as the Coyolcos bobwhite (Colinus coyolcos, Müll.). They were common, and although their garb had changed considerably, yet their voices and mode of life remained true to the family traditions. Indeed, so fixed are old habits among them that even long association with the suave and politic Mexican has failed to cure Bob of one custom that I often deplored during my youthful days, when, gun in hand, I sought to make his acquaintance. I refer to that abruptness of manner which is shown in such a lisconcerting way when one comes upon him in his favorite haunts.

"Near Tehuantepec their home is on the partly wooded and partly grassy plains. Old fields and grassy prairies, that extend irregularly amid the scrubby forests 
of that district, are their favorite haunts. Here the mesquites, mimosas, acacias, cassias, Brazil-wood, ebony, mahogany, Spanish cedar, and other tropical trees and bushes, give the landscape quite a different aspect from that which Bob is accustomed to see in his northern home. Old cornfields and weedy indigo plantations are popular resorts, and furnish an abundance of food. Brush fences of thorny scrub are built about these fields, and serve as fine places of shelter in times of danger. The quails do not penetrate heavily wooded bottoms along streams, where the moisture causes a vigorous tropical forest growth, unless some farmer hews out a clearing for his cornfields. In these forest belts the motmots, trogons, red-and-yellow macaws, several species of parrots and other tropical birds, abound, and a little farther south troops of spider monkeys are encountered. In many places it is but a few steps from the dense shacle of the bottoms, where the harsh screams of the macaws dominate all other woodland notes, to the borders of grassy prairies where our friends pass their sedate lives, associated with meadow-larks and sparrows. Throughout this region, where deer, peccaries, tree pheasants and other game is plentiful, smaller birds are considered unworthy of powder and shot, all of which conduces greatly to peace of mind among the bobwhites.

"While traveling down the coast from Tehuantepec into Chiapas, we found them numerous most of the way, and they were a constant sonrce of interest and pleasure. Their cheerful notes were frequently heard 
from the scrubby bushes near the trail, and the neat, trimly-built little fellows carried on their small affairs with little regard for our presence. While riding at the head of the pack train, I frequently found them scratching in the sandy trails, dusting themselves, or searching for food. At such times it was amusing to note the pretty air of doubt and hesitation with which they awaited my approach before finally moving rather deliberately a few yards to one side when I came too near. Now and then the male could be heard uttering little querulous notes, as if in subdued protest at being disturbed. After entering Chiapas the coast was left behind, and we passed into the interior through a series of beautiful open valleys ornamented with scattered bushes and belts of trees. It was during the rainy season, and the vegetation was growing luxuriantly; everywhere were myriads of flowers, and the innumerable plumelike heads of tall grasses nodded gracefully in the passing breezes. In these valleys the bobwhites were very common. It generally rained during the night, but the clouds broke away at dawn, leaving a brilliantly clear sky. We were up and on our way at sunrise, amid the invigorating freshness of early morning, when every leaf and twig bore a pendant waterdrop that sent out quivering rays of light with the first touch of the sun. On every hand were new flowers and strange birds. Now and then the Central American mockingbird, in full-throated ecstasy, poured out its rich song, and over it all, at short intervals, the clear call of bobwhite arose from a bush or low tree. At 
an altitude of about 3,000 feet we passed out of their range, and did not find them again until we reached the valley of Comitan, on the Guatemalan border, where their notes were heard. A few miles farther on, just after entering Guatemala, a single female, which proved to be quite different from those taken in Mexico, was brought me by an Indian. This specimen served as the type of the Guatemala bobwhite (Colinus insignis, Nelson). Beyond this nothing was learned of them in these remote parts.

"From Comitan Valley we made a long circuit over the Guatemalan highlands and reached the Pacific coast again, on the border of Chiapas. There, on some grassy prairies in the midst of the forested coast plain, a few miles back from the sea, we found many bobwhites of a previously unknown branch of the family (Colinus salvini, Nelson). In this vicinity an attempt was made, many years ago, to establish a large colony of Americans. They came with great flourish of trumpets and large expectations, but the climate did its silent work so effectually that two or three stranded relics were all that remained. Over the desolate sunscorched flats near by the same cheery call of the quail sounded in the ears of the Mexican oxdrivers and muleteers as they carried their cargoes of coffee and cacao to the coast, that I heard from many a field and thicket over thousands of miles of varied country to the north. Among these sturdy little Americans there appeared no sign of degeneration, and it was pleasanter to meet them than some of my countrymen 
of a larger growth. So many failures at colonizing people from the north in these hot southern lands had come to my notice that I had become skeptical of its successful accomplishment in any instance; yet here in the tropics were the bobwhites, essentially a group of the temperate regions, living as cheerfully as possible, and upsetting my preconceived ideas.

"After passing some time in this district we hired an oxcart one evening, and were trundled across the plains to the coast during the cool hours of the night. There, on the sandy shore, we waited ten days for a steamer, which finally carried us back to Tehuantepec. From this place a railroad crosses the Isthmus to the port of Coatzacoalcos, on the Gulf of Mexico, and we took advantage of it to reach the eastern coast. Coatzacoalcos is a curious little town, destined to play an important part in the development of southern Mexico and western Guatemala. It is one of the few places in Mexico where small frame hauses are the prevailing style, and reminds one more of some small mining camp in the Far West than of a seaport on the Gulf of Mexico. Here, where yellow fever, malaria and other ills stalk about, according to the season, we heard of howling monkeys, jaguars, tapirs, and other tropical creatures with which we still desired to become more familiar. For this purpose we ascended the Coatzacoalcos River about twenty miles, to the town of Minatitlan, a place once noted for its enormous trade in Spanish cedar and dyewoods. We remained here some days, in the midst of the coast low- 
lands, where the tropical forest is interrupted by grassy prairies of considerable extent. In visiting these prairies we were surprised and delighted to find another of the bobwhites that had not been previously known even to those most familiar with the ramifications of this good old stock (Colinus godmani, Nelson. Afterward we found them a few miles out of Coatzacoalcos, and they were also seen a little farther north, in the open country about the shores of beautiful Lake Catemaco. This latter point is probably near their limit in direction.

"The distribution of the Mexican bobwhites is curious, and shows that the family has been long in the land. They range over parts of the cool tableland, and extend down to the tropical lowlands of both coasts, but are unaccountably absent from many apparently suitable places.

"Many changes have taken place in their garb owing to the influences and requirements peculiar to such varied situations, but the general style is retained, so that their relationship cannot be mistaken.

"A representative of this group lives in Yucatan, which, it is said by some, belongs to the family proper; but if this is so, there must be a bar sinister on its escutcheon to account for some of its peculiarities.

"At present eleven branches of bobwhites are known to live in various parts of Mexico, and our work has enabled us to introduce four of them to the friends of the family. Wherever they were encountered over this great area it was interesting to observe how closely 
they continue to resemble one another in notes and habits. From the border of Canada to Guatemala they hold true to a general style of speech and manners that always betrays their connection, with the possible exception of the Yucatan branch, of which I am unable to give any definite information.

"For the charming qualities and pretty ways of these little friends of the field, I trust their days may be many and their numbers never grow less.

"As it is quite possible that some of our mutual friends may have the opportunity to call upon these Mexican connections of 'our Bob,' I have taken some trouble to secure their names and addresses, which are given below. The directory is complete, I believe, up to date.

"I. Colinus ridgwayi (Brewster). Ridgway's bobwhite. Sonora; ranging south from the Arizona border. (Between I,Ooo and 2,500 feet above sea-level.)

"2. Colinus virginianus texanus (Lawr.). Texas bobwhite. Northeastern Mexico; Nuevo Leon and Tamaulipas. (From near sea-level up to 2,500 feet.)

"3. Colinus graysoni (Lawr.). Grayson's bobwhite. Southern part of tableland; from San Luis Potosi and northern Jalisco to Valley of Mexico (3,000 to 7,500 feet).

"4. Colinus graysoni nigripectus (Nelson). Puebla bobwhite. Tableland of southern Puebla (3,000 to 6, ooo feet).

"5. Colinus pectoralis (Gould). Black-breasted bobwhite. Eastern base of Cordillera in Vera Cruz; 
from Jalapa to Isthmus of Tehuantepec (500 to 5,000 feet).

"6. Colinus godmani (Nelson). Godman's bobwhite. Lowlands of southern Vera Cruz; probably also ranging into Tabasco. (From sea-level to I,500 feet.)

"7. Colinus coyolcos (Müll.). Coyolcos bobwhite. Pacific coast of Oaxaca and Chiapas; from city of Tehuantepec to Tonala. (From sea-level to 3,00o feet.)

"8. Colinus atriceps (Ogilvie-Grant). Black-headed bobwhite. Putla, western Oaxaca. (About 4,00o feet.)

"9. Colinus salvini (Nelson). Salvin's bobwhite. Coast plains of southern Chiapas, near Guatemalan border. (Sea-level to 500 feet.)

"Io. Colimus insignis (Nelson). Guatemala bobwhite. Valley of Comitan in Chiapas, into adjacent border of western Guatemala (3,000 to 6,00o feet).

"I I. Colinus nigrogularis (Gould). Yucatan bobwhite. Yucatan. (Sea-level to 500 feet.")

Very different in appearance from the bobwhite group are the striking quails of the western and southwestern portions of the United States. Of these birds there are almost a dozen forms, some of them plumed, others helmeted, others with full, soft crests, but all very unlike the bobwhites. These are among the most beautiful of North American birds, and in many of the regions which they inhabit are extremely abundant. 


\title{
MOUNTAIN QUAIL:
}

\author{
Oreortyx pictus. \\ Oreortyx pictus plumiferus. \\ Oreortyx pictus confinis.
}

This is one of the largest of our quails. Its upper parts are brown or olive, or sometimes even bluish, the inner webs of the tertiary feathers being buff, so that when the wings are closed a distinct stripe is seen on each side of the rump. The breast and head are in part lead color; the long, backward directed crest of narrow feathers growing from the top of the head is black; the throat is chestnut, and from this a black stripe runs up to the eye. The chin, front of cheeks, lower portion of the lores, a line bordering the throat patch from the posterior angle of the eye and forehead, are whitish. The effect of this is to surround the bill with a border of whitish. The flanks are deep chestnut barred with black and white. The thighs are reddish and the under tail coverts black. In color, the female is very similar to the male, but usually has the crest plumes smaller. The length is from II to 12 inches, and the wing from $5^{1 / 4}$ to $5^{1 / 2}$ inches.

This is the typical mountain quail, ranging in the California mountains from Santa Barbara, Cal., north to Washington. In Oregon its range seems to extend 76 
out to the eastward, where it has been found near Mt. Hood. It was first found north of the Columbia River a good many years ago, and later was introduced near Seattle, at Vancouver Barracks, and also on Whidbey Island, in Puget Sound, where the birds have done well.

The plumed partridge (Oreortyx pictus plumiferus) is a paler race, grayish olive above, but often with the neck more or less lead-colored, like the breast, the edges

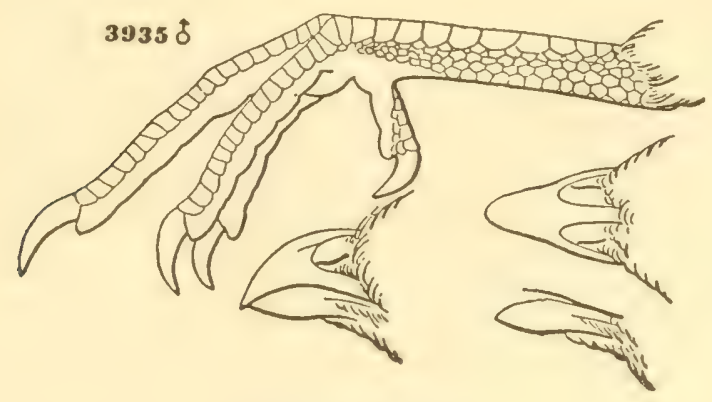

MOUNTAIN QUAIL

of the tertiary feathers whitish, and the forehead white. It is found on both sides of the Sierra Nevada, from eastern Oregon southward, and through California south to northern Lower California.

The San Pedro quail (Oreorty.x pictus confinis) is a still paler race, with a thicker bill, first found in the San Pedro Mountains of Lower California. According to Mr. Anthony, it ranges high up on both sides of the mountains, to the highest peaks, estimated at about $\mathrm{I} 2,500$ feet, and is not common below 2,500 feet. 
The mountain quail is perhaps the most beautiful American quail, though in such an attractive group it is hard to say that one is handsomer than another. The range of the species is limited to the mountains of the Pacific coast, from Washington south through Oregon and California, as stated.

Captain Bendire quotes Prof. O. B. Johnson, of the University of Washington, to the effect that its northern range has been extended by artificial means. He says:

"Twenty years ago this species was found but little north of the Willamette Valley, Oregon, but they gradually worked down the south side of the Columbia River, toward Astoria, and in I872 I was informed that some of these birds, shot at Kalama, Washington, were the first seen north of the Columbia. A crate of trapped birds sent to the Seattle market were, some time afterward, purchased by the Young Naturalists' Society and set free. These have since multiplied nicely, and others have been sent to Whidbey Island, forty miles north of Seattle, where I understand they are also doing well. A covey wintered in a barn lot with the hens just at the outskirts of Seattle this winter."

Quite a number were also liberated near Vancouver Barracks, and did well. It is a moisture-loving species, and delights in a country where the rainfall is heavy. The paler race of this species is found in the drier regions of the Sierra and some of the desert ranges.

This is quite an abundant species, found high up on the mountains in stmmer, and also low down toward 


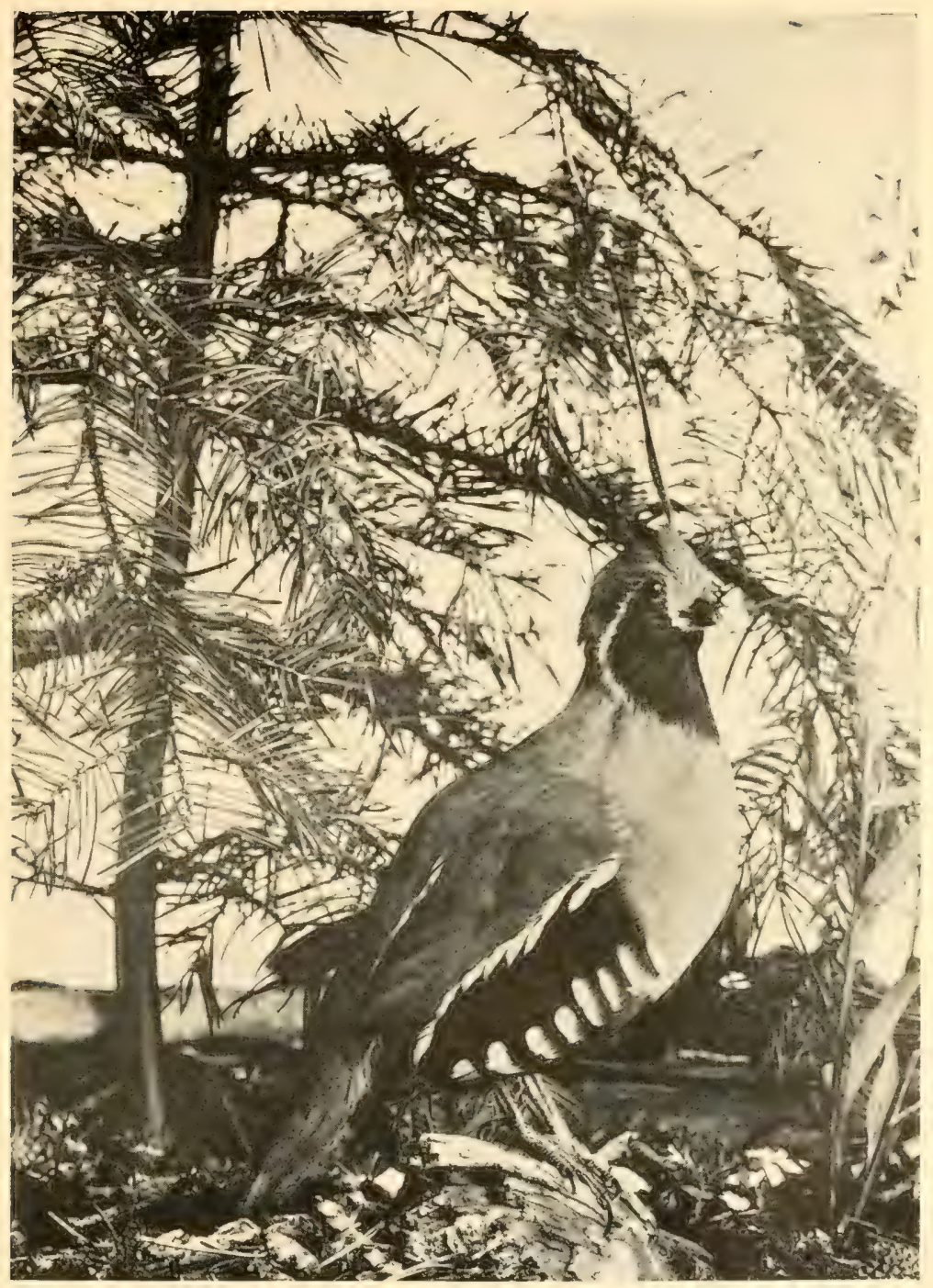

Mountain Quail. 

the desert in winter. It is said that in spring many follow up the snows as they melt, spending the summer high up on the mountains, and then in the autumn return down the slopes, below the point where snow lies. The birds have a call not very unlike that of the bobwhite, a whistle of three syllables, and the attitude assumed by the male while calling is not unlike that of the common quail, the wings being drooped and the point of the bill raised. The food consists of insects, seeds, berries, and the buds and tops of tender plants. In the early spring they feed so much on the tops of the wild garlic-one of the first green things to appear - that the flesh sometimes tastes of the plant.

This quail is a prolific breeder, the eggs usually varying in number from 9 to $I_{5}$, though sometimes they are much more numerous, a nest containing I9 eggs being reported, as also a brood of 20 young birds. The time of nesting varies from early April to late May. The eggs are white.

In northern Lower California Mr. Anthony found that the San Pedro partridge does not differ greatly in habit from the other forms. The race is confined to southern California and northern Lower California.

The mountain quail is a bird only casually pursued by the gunner. Often they are flushed and shot, and in some localities they are regularly pursued with dogs and shot over points. In such places they are reported to lie close, and to offer good opportunity for sport.

The situations in which they are often found, rough mountain slopes, overgrown with manzanita, chemisal 
and other chaparral, will long protect them, and make the work of shooting them very difficult for the dog, and hardly less so for the gunner. When the birds take wing they are swift fliers, and soon out of sight.

It has been suggested that these birds would do well in various localities in the southern Alleghany Mountains, where they might take the place of the native species, which seem to be growing scarcer. I do not know, however, that any serious effort has been made to acclimate them in such localities. 


\section{SCALED PARTRIDGE; BLUE QUAIL.}

\section{Callipepla squamata.}

Callipepla squamata castanogastris.

In size, not far from the Virginia quail ; with a short, thick crest, white at the tips. The rest of the head is brownish or grayish, growing paler on the throat. The back part of the neck, back and breast are bluish gray. A black border to each feather warrants the name "scaled." The wings are pale brown, and the flanks streaked with white. Other lower parts are buffy or yellowish, the belly sometimes with a patch of chestnut brown. Sexes alike. Length, 9 to Io inches. Eggs white or buff dotted with brown. Inhabits northwestern Mexico, and the horders of the United States, from western Texas to southern Arizona.

The chestnut-bellied scaled partridge has the wings tipped with brown, tail bluish gray, the lower parts behind deeper buff, sometimes yellowish, and a large patch of rusty chestnut on the belly in the male and sometimes in the female. This bird is found in eastern Mexico and in the lower Rio Grande Valley of Texas. In northern Mexico, along the southwestern border of the United States, from western Texas through southern New Mexico and Arizona, the scaled partridge is abundant. 
The birds seem to shun the timber, and to be most abundant on the high mesas, preferring the dry and barren country. Mr. Herbert Brown, however, speaks of having seen them immediately about water as well as far away from it. Captain Bendire, however, intimates that his experience leads him to think that the bird scarcely requires water. Mr. E. W. Nelson tells us that, while he has often found them far from water, they nevertheless make regular visits to the watering

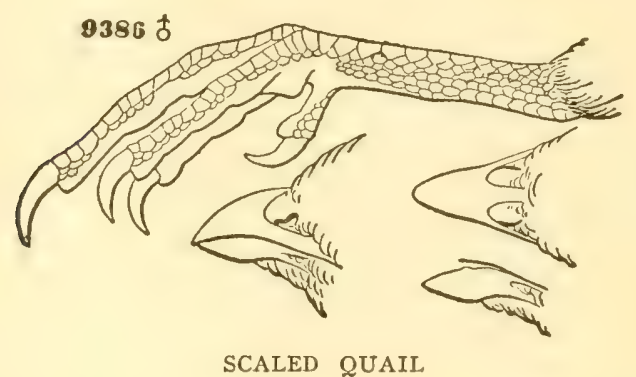

places. All observers agree that they are exceedingly shy and hard to approach, and that they are swift runners, dodging in and out among the bushes with the greatest ease, and soon out of sight. Even if flushed they fly but a short distance, when they alight and run again. Like many other gallinaceous birds, they greatly enjoy taking dust and sand baths, and at such times they act much like young chickens. In the evening they retire to roost, to ridges and knolls, and the birds call to each other until the bevy has come to- 


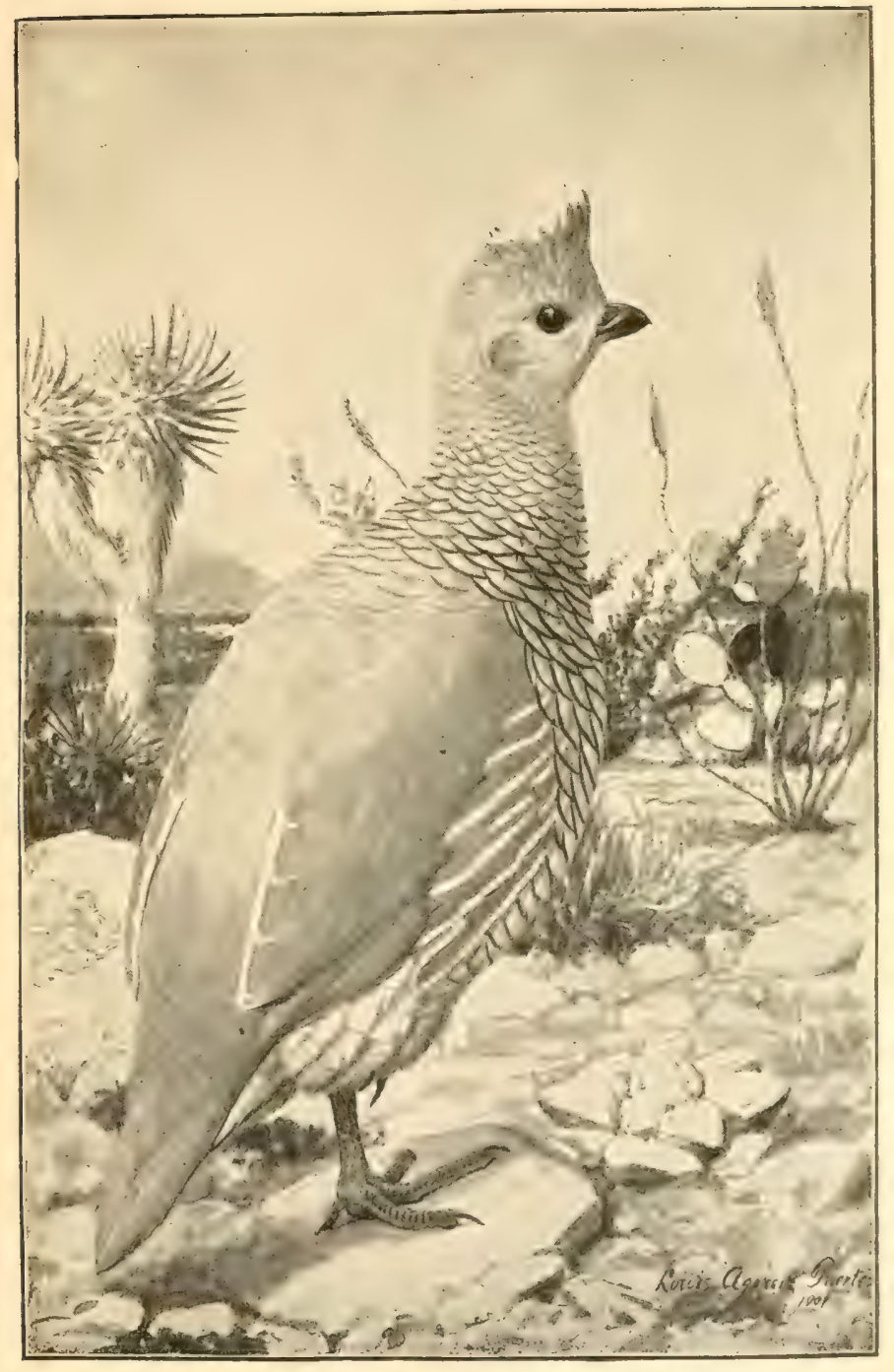

Scaled Partridge. 

gether again. Sometimes the birds collect in considerable numbers, 60 or 80 having been seen together.

The breeding season begins in March, and the young birds are usually hatched by the first of June, or earlier. There is some reason to think that two broods are reared. The number of eggs ranges from 9 to 16 , and is commonly about II or I2. The eggs are sometimes dead white, or again pale buff in color, and are dotted with very small reddish brown spots scattered over the entire egg.

The scaled partridge is not a bird pursued for sport. It is true that many of them are killed by gunners, but merely for the food they afford, the birds being potted on the ground at every opportunity.

Of all the quail, this is the most difficult to make lie to dog or man. In Arizona the army officers used to hunt them on horseback, following up the birds and shooting them whenever and however they could.

The scaled quail, which is also sometimes called white topknot quail, or cottonhead, does not differ in habits from its relative, the chestnut-bellied scaled partridge.

Concerning the scaled partridge in southern Arizona, Mr. Herbert Brown, of Tucson, writes me:

"The blue quail are less common than Gambel's quail, and do not, as a rule, live on the desert proper, but incline rather to the higher and rougher foothills. I saw a dog tried on only one, but am inclined to believe in their sprinting qualities. I have shot them in the foothills of the Tucson Mountains, west of here, and as far 
east as the Graham Mountains, where I found them quite plentiful. They are quick, active birds, and as pretty as pictures. I take it for granted that they are found much further east, but the eastern slope of the Grahams is as far as my personal acquaintance goes." 


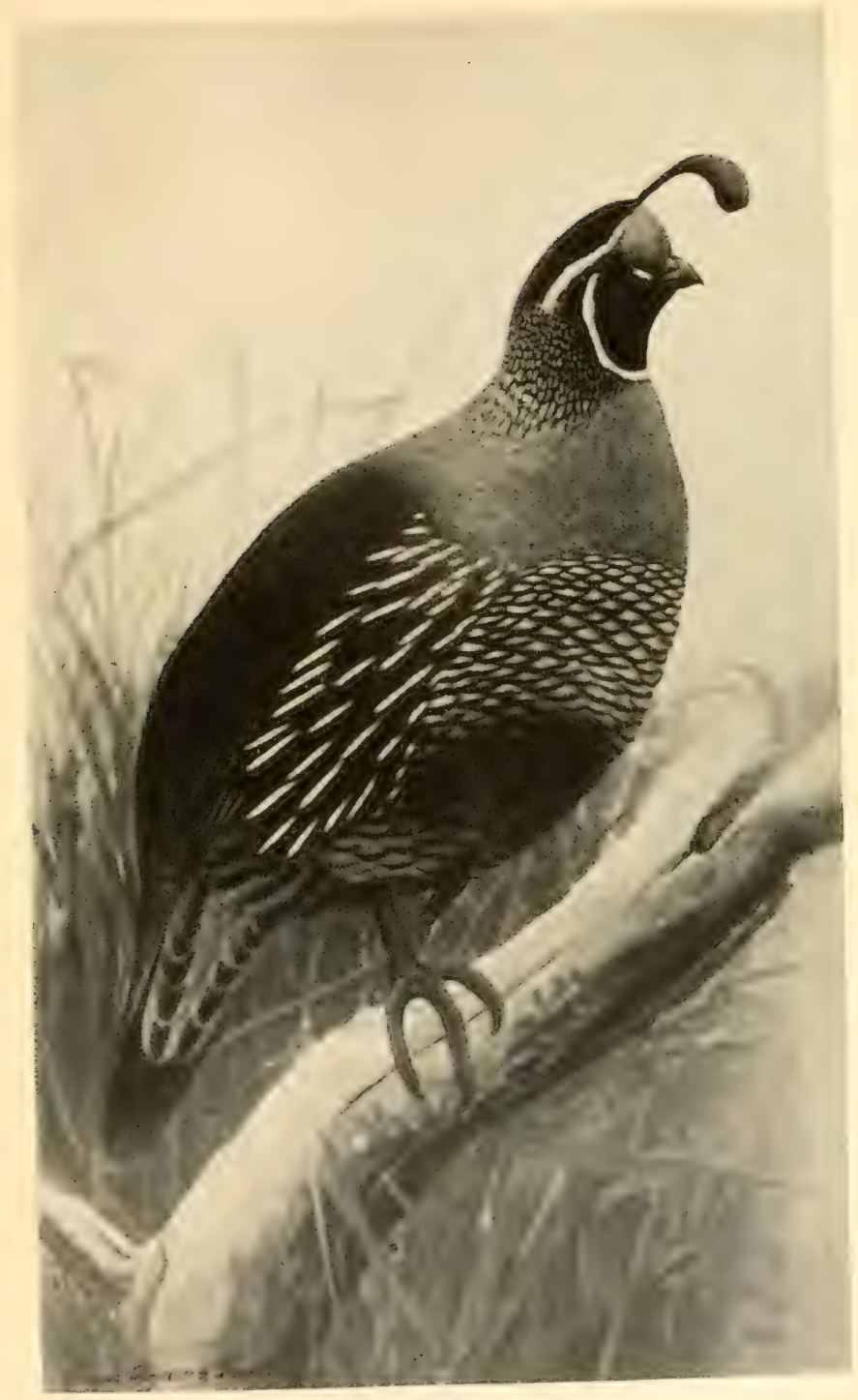

California Quail. 



\title{
CALIFORNIA QUAIL; VALLEY QUAIL.
}

\author{
Lophorty.r californica. \\ Lophorty.t californica vallicola.
}

Two forms of this species are found on the Pacific coast: a northern race, inhabiting the coast of California north of Monterey, and which has been introduced in British Columbia, Washington and Oregon, and a paler race found in the interior valleys and foothills of California, south through Lower California to Cape St. Lucas.

In the California quail the flanks are streaked with white on a brown or grayish ground. The feathers of the belly, in the male, are edged with black, and have a central patch of chestnut. The upper parts generally are smoky brown, the inner edges of the tertiary feathers buffy, the throat black, and the forehead whitish. The female has no black or white on the head, is plain grayish or brownish, lacks the chestnut belly patch, and has the scale-like markings of the under part less distinct. The crest is much shorter than in the male. The length is $9^{T / 2}$ or Io inches, and the wing about $4^{1 / 2}$. This is the bird found in the coast valleys of Oregon and Washington and California.

The valley quail ( $L$. californica vallicola) is paler, being grayish brown, the inner edges of the tertiary 
feathers whitish, and the flanks grayish brown. It is a bird of the interior districts of California and Oregon, south to Cape St. Lucas.

The valley quail is an abundant species on the coasts of California, Oregon and Washington, and has been introduced on Vancouver Island and on a number of the islands of Puget Sound. This, according to Dr. Suckley, was done by Governor Charles H. Mason and Mr. Goldsborough, as early as the year 1857. They

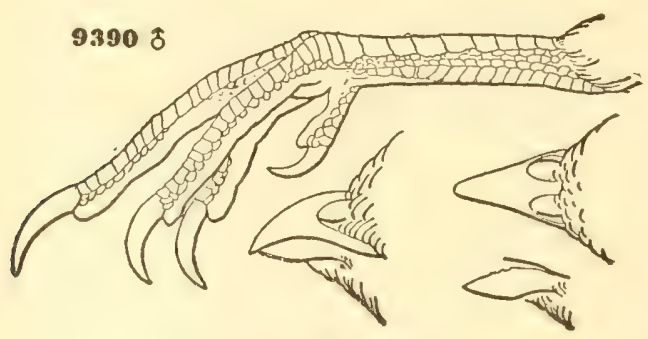

CALIFORNIA QUAIL

have long been common on Whidbey Island and on Vancouver Island, where they make, according to my experience, far better shooting than they do in the dry country of California.

Of the two races, the California quail belongs especially to the coast, and the paler grayer form is found in the drier interior, from western and southern Oregon south, through western Nevada and interior California, to Cape St. Lucas, Lower California. This species is still abundant, and many broods are found on some California ranches. In some places they 
are not popular, because believed to eat the grapes. Others more justly believe that the number of noxious insects devoured by the valley quail far exceeds in importance the small amount of fruit which they eat.

In many places the too long open season and unreasonable bag limit have sadly depleted their numbers, and unless complete protection or restocking is resorted to this beautiful bird will become locally rare.

The habits of this species differ very much in different localities. They are tough, hardy birds, and sometimes surprise the ornithologists by turning up in places where they would not at all be expected. On the other hand, they sometimes suffer severely from cold and snow.

Mr. A. C. Lowell, writing from Ft. Bidwell, in northeastern California, reported to Captain Bendire: "These birds are unable to stand the severe cold of this region, especially when accompanied by a heavy fall of snow. In the winter of $1887-88$ about two feet of snow fell, followed by three very severe nights in which the thermometer reached $28^{\circ}$ below zero. This killed most of the birds. In the following fall I heard of but three or four coveys of quail within a radius of sixty miles, where thousands had been the year before. They ranged from the northern end of Warner Valley south to Reno, Nevada, and were especially numerous in Buffalo Canyon and along the western shore of Pyramid Lake. They were very common up to the summits of the Warner Mountains, which attain here an altitude of about 6,000 feet. Though the canyons 
and water courses along those slopes were their favorite resorts, I have never seen nor heard of a covey of these quail down in the cultivated fields of the valleys. Here, at least, they prefer to live exclusively on the brushcovered hillsides."

On the other hand, we have known of cases in California where a brood of quail came regularly every evening to drink from the fountain immediately in front of a ranch house. In certain parts of southern California the quail has found the orange trees safe roosting places, and in the evening comes down from the brush-covered hills to the orchards.

In Lower California, Mr. A. W. Anthony found the valley partridge very common in the mountains up to an altitude of about 9,000 feet.

He adds: "Both in southern and Lower California I was told by the Indians and native Mexicans that during very dry seasons the valley quail do not nest, but remain in flocks during the entire summer. This statement I was able to verify by personal observation during the summer of I887. These birds were seen by me in large flocks throughout the spring and summer months, and only two or three broods of young were noticed. Birds taken during April, May and June showed but little development of the ovaries. Should the winter rains, however, be sufficient to insure an abundance of seeds and grasses, the coveys begin to break up early in March, and from every hill in the land the loud challenge of the male is heard. The call notes of this sub-species are quite varied, fre- 


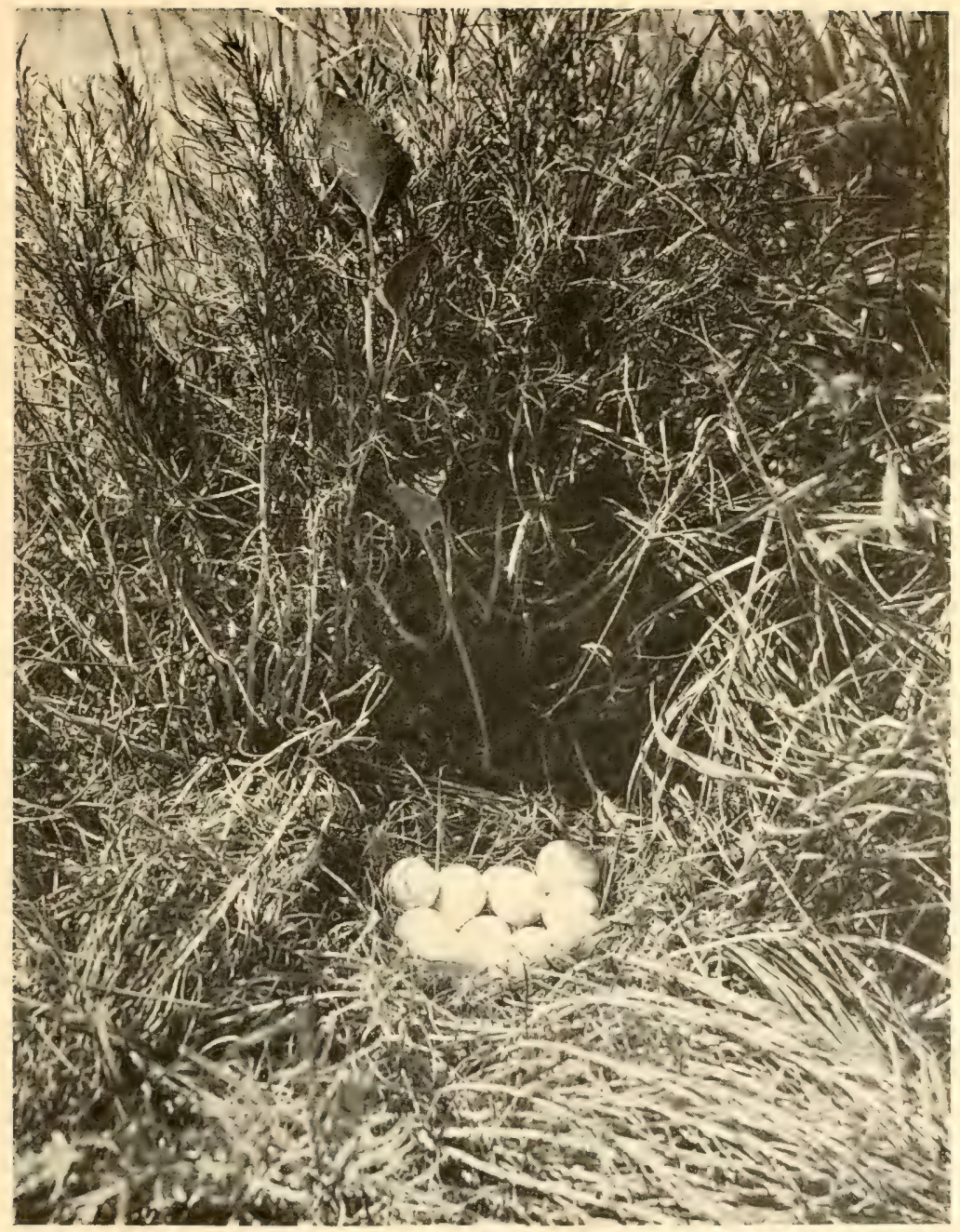

Nest of California Quail. 

quently the same bird changing his call six or seven times within half an hour."

Mr. William Proud wrote Captain Bendire from Butte County, California, concerning this species, as follows :

"Hundreds of these birds roost every night in the shrubbery around my house. Some of them are very tame, feeding among the chickens and coming on the verandah. They appear to know that they are protected. They mostly roost in thick brush, and on the ground when the brush is not at hand. In early seasons they begin to pair in the last week of February, but the time varies somewhat according to the season. During this period there is considerable fighting among the males for the favor of the coveted female. This is kept up until they are suitably mated and the nesting season arrives. This usually begins here about the last week in March; when the pairs scatter among the shrubbery along the banks and creeks and in adjacent ravines, along hedgerows and brush fences, and on the borders of cultivated fields. The earliest nest I ever found was on March I5, and on April I5 I met young birds probably a couple of days old. I consider I4 eggs to be about the average number laid by these birds, and have found as many as 24 in a nest. The large sets I attribute to other hens laying in the nest, probably young birds which have failed to make preparation for their own eggs. On May 2 I my dog pointed a valley partridge on her nest, which contained 22 eggs, and every one hatched. 
"During incubation the male is very attentive and watchful, usually taking an elevated position near the nest, where, with crest erect and tail spread, he bids defiance to all intruders, uttering an oft repeated wherv-rherv-zhere. When the breeding hen leaves the nest to feed, should he be absent from the post of duty, her cry of tobacco-tobacco, very plainly given, brings him up at once. ...

"As soon as the young are hatched they immediately leave the nest, keeping under cover as much as possible. Should the brood be disturbed, the old birds will run and flutter along the ground to draw the attention of the dog, or whatever may have frightened them, to themselves and away from the young. In about ten days these can fly a short distance. The valley partridge feeds on insects and the young and tender leaves of clover and green peas; later, on grain and various small seeds; in the fall they eat wild grapes, and are also very partial to the seeds of the amaranth, alsc those of Mentaclia lavicanlis. Here only one brood is raised in a season, and incubation, as nearly as I can ascertain, lasts about twenty-eight days."

The eggs of this species range from 12 to 16 , nests occasionally, as already stated, containing many more. The eggs are cream-white in color, spotted and blotched with different shades of dark and light brown and drab scattered over the whole egg. 


\section{GAMBEL'S QUAIL.}

\section{Lophortyx gambeli.}

This is a richly-colored bird, and has the flanks bright chestnut streaked with white. There are no scalelike markings on the belly, and the central patch is black, the forehead dark, and the back of the head reddish. The upper parts are much as in L. californica. The female resembles that of $L$. californica vallicola, but has the flanks chestnut and the belly without any trace of scalelike markings. It is, perhaps, a little larger than the California partridge. Its range is northwestern Mexico and the neighboring portions of the United States, from southern California and Arizona to western Texas, and north as far as southern Utah.

Besides this, other species of this genus are found in Mexico, and in one or two of these the sexes are markedly unlike.

Gambel's quail is a dweller in the desert country of the south, and ranges from eastern southern California through Arizona, and much of New Mexico, into western Texas. It is also found in southern Nevada and portions of Utah, and south into western Mexico.

With a general similarity to the valley quail, it has 
habits not unlike that species, except so far as these habits are modified by its different surroundings.

Like many gallinaceous birds, Gambel's quail is very social in habit, and at the proper season they get together in great flocks, and when alarmed and driven to wing may get up all about one, only to disappear almost at once among the thick cover or in the distance.

Dr. Coues, in his article on this species published in "The Birds of the Northwest," designates the valleys of the Gila and Colorado as its centers of abundance. This article is well worth quoting in part, as painting charming pictures of a region little known to most sportsmen, but one of extreme interest.

He says: "An interesting fact in the distribution of this species is the effect of the Colorado desert in shutting it off from the fertile portions of California. This dreary, sterile waste offers a barrier to its westward extension that is only exceptionally overcome. Although the bircls enter the desert a little way, they rarely reach far enough to mix with the representative species of California ( $L$. califomicus). The strip of country that mostly assists in their occasional passage westward is along the Mojave River, a stream rising in the San Bernardino Mountains, and flowing eastward toward the Colorado, from which it is shut off by a range of hills, and consequently sinks in the desert at Soda Lake. Among other birds, the two kinds of plumed quail-Gambel's and the California-meet along this comparatively fertile thoroughfare upon neutral ground, as Drs. Heermann and Cooper, as well as 
myself, have witnessed. Much further south Colonel McCall found birds at Alamo Mucho, forty-four miles west of the Colorado; but still the desert is in effect the barrier I have represented, and the two quails, speaking generally, do not meet. One wonders the less at this who has any good idea of the Colorado desert, such as may be gained, for example, from the following passage from Colonel McCall's article, which remains associated in my mind with the plumed quails, with all the freshness of first impressions. Speaking of the Alamo, where he shot a pair, 'Here is in truth a desert!' exclaims the colonel. 'Figure to yourself, if you can, a portion of this fair earth where for some hundreds of miles the whole crust seems to have been reduced to ashes by the action of internal fires; behold a vast plain of desolation, surrounded, and at intervals intersected, by abrupt mountain ranges which are little better than gigantic heaps of scoria. Imagine this scenery to be actually glowing under the direct rays of the midsummer sun, and you may have some idea of the prospect that meets the eye of the traveler who looks out upon the desert from the well of the Alamo. You may perceive in his rear a few stunted cottonwood trees, scattered along the edge of a channel in which apparently water once was, but now is not; while around him, here and there, is a light-leaved mesquite that stretches forth its slender arms and appears to invite him to a shade that is but a mockery. Here it was that I first heard the plaintive voice of this bird as he strove to cheer his mate while occupied in the tedious task 
of incubation.' And singularly enough, the bird is almost equally hemmed in by desert to the eastward as well; for according to the same writer's accounts, 'A sandy desert between the Pecos and Devil's River is the barrier beyond which the species under consideration has not extended its range.'

"Such a glimpse of the haunts of the plumed quail makes one wonder how it ever became a game bird at all; how sportsmen could be able to make game of it without being themselves rather made game of. But great as are the natural disadvantages of the surroundings, the bird's attractions are still greater, and partly so from this very fact; but Arizona is a large place, and one need not always endure desert in his quail-shooting. There is a much brighter side to the picture. We have just seen only the darkest possible. Perhaps no territory rivals Arizona in variety of climate, physical geography and natural productions. Between rugged mountains that lift snow-capped peaks among the clouds, lie hidden pleasant green valleys whose fresh verdure contrasts with surrounding desolation. Vast primeval forests stretch for leagues, or are only interrupted by oak and cedar openings. Bright fringes of cottonwoods and willows mark the devious courses of streams, where walnut and cherry are scattered, and grape vines cling to them and roses bloom beneath leafy boughs. Here is plenty, at least, if not peace. Nothing mars the pleasures of the chase but the chances of being chased. Were it not for Indians, we should have here the acme of quail-shooting. 
"Gambel's quail may be looked for in every kind of cover. Where they abound it is almost impossible to miss them, and coveys may often be seen on exposed sand heaps, along open roads, or in the cleared patches around settlers' cabins. If they have any aversion, it is for thick, high pine woods without any undergrowth ; there they only casually stray. They are particularly fond of the low, tangled brush along creeks, the dense groves of young willows that grow in similar places, and the close-set chaparral of hillocks or mountain ravines.

"I have often found them also among huge granitic boulders and masses of lava, where there was little or no vegetation except some straggling leaves, and have flushed them from the dryer knolls in the midst of a reedy swamp. Along the Gila and Colorado they live in such brakes as I have described in speaking of Abert's finch, and they frequent the groves of mesquite and mimosa that form so conspicuous a feature of the scenery in those places. These scrubby trees form dense interlacing copses, only to be penetrated with the utmost difficulty; but beneath their spreading, scrawny branches are open, intersecting ways, along which the quail roams at will, enjoying the slight shade. In the most sterile regions they are apt to come together in numbers about the few water-holes or moist spots that may be found, and remain in the vicinity, so that they become almost as good indication of the presence of water as the doves themselves. A noteworthy fact in their history is their ability to bear, without apparent 
inconvenience, great extremes of temperature. They are seemingly at ease among the burning sands of the desert, where for months the thermometer daily marks a hundred, and may reach a hundred and forty, 'in the best shade that could be procured,' as Colonel McCall says; and they are equally at home, the year round, among the mountains, where snow lies on the ground in winter.

"The quail's food is made up of various substances. Like the rest of its tribe, it is chiefly granivorous, eating seeds of every description; but fruits and insects form a large portion of its fare. It devours insects of such sorts as it can capture, and particularly those kinds that infest plants. In the fall it gathers cherries and grapes, and other 'fruits,' properly speaking, as well as the various berries not usually so called. It visits patches of the prickly pear (Opuntia), to feed upon the soft, juicy tunas, that are eaten by everything in Arizona, from men and bears to beetles. In the spring it shows fondness for the buds of different plants, particularly mesquite and willow; birds shot at this time are frequently found with sticky bits of the buds about their bills. But though they thus feed so extensively upon this substance containing salicine, I never noticed that the flesh acquired a bitter taste. There is, as yet, little cultivated grain in Arizona, but doubtless some future historian will have to add our cereals to the bird's list, and speak of Gambel's quail as frequenting old corn and wheat-fields and the neighborhood of hayricks, where a large share of its food is to be gleaned. Like 
other Gallinc, it swallows quantities of sand and gravel to facilitate, it is supposed, the trituration in the gizzard of the harder kinds of food.

"I believe that the quail moults at least twice a year, but the spring change is apparently less complete, and certainly more gradual, than that of the fall, the birds seeming rather to furbish up a part of their plumage than to furnish themselves with entirely new attire. By the latter part of summer (at Fort Whipple) the plumage is faded and worn with incubation and the care of the young, and the renewal begins as soon as the latest brood is reared. The process is a long one, and the birds are rarely found at any season in such poor condition as to be unfit for preservation, nor are they ever deprived of flight. No crest is occasionally found for a short time in early autumn, but new feathers generally sprout before all the old ones are dropped. I think they are shed from behind forward, so that the front ones are lost the last. The fully developed crest is a striking and beatitiful ornament, hardly to be surpassed in stylishness and jaunty effect. It averages an inch and a half in length, and sometimes reaches two inches in the most vigorous males; in the female it is rarely over an inch. The male's is a glossy jet black; the female's has a brownish cast. The number of feathers composing it is variable; five or six is usual, but there may be ten. They all spring from a single point on the top of the head-just behind the transverse white line that crosses the crown from eye to eye. The feathers are club-shaped, enlarged at the tip and curling over 
forward, together forming a helmet-shaped bundle. The webs are loose; they bend backward from the shaft so that this forms the front border of the feather. Each feather is thus folded or imbricated over the next succeeding, and the whole are packed into a single fascicle in this manner. The crest is freely movable, and its motions are subject to voluntary control. It is usually carried erect, but sometimes drops forward, or obliquely, over one eye, and occasionally is allowed to hang backward, though it cannot be made to lie close over the occiput. The crest sprouts when the chicks are only a few days old, about the time that the first true feathers appear upon the wings and tail. . . .

"All quail are Pracoces, as already explained, and the chicks of this species are certainly precocious little things, if we may judge by their actions when they are disturbed. They run about as soon as they are hatched, though probably not 'with half shell on their backs,' as some one has said. In a few days they become very nimble, and so expert in hiding that it is difficult either to see or catch them. When the mother bird is surprised with her young brood, she gives a sharp warning cry that is well understood to mean danger, and then generally flies a little distance to some concealed spot, where she crouches, anxiously watching. The fledglings, by an instinct that seems strange when we consider how short a time they have had any ideas at all, instantly scatter in all directions, and squat to hide as soon as they think they have found a safe place, remaining motionless until the reassuring notes of the mother 
call them together again with an intimation that the alarm is over. Then they huddle close around her, and she carefully leads them off to some other spot where she looks for greater security in the enjoyment of her hopes and pleasing cares. As long as they require the parents' attention they keep close together, and are averse to flying. Even after becoming able to use their wings well they prefer to run and hide, or squat where they may be, when alarmed. If then forced up, the young covey flies off, without spreading, to a little distance, often realighting on the lower limbs of trees or in bushes, rather than on the ground. As they grow older and stronger of wing they fly further, separate more readily, and more rarely take to trees; and some time before they are full grown they are found to have already become wary and difficult of approach. As one draws near where a covey is feeding, a quick, sharp cry from the bird who first notices the approach, alarms the whole, and is quickly repeated by the rest as they start to run, betraying their course by the rustling of dry leaves. Let him step nearer, and they rise with a whirr, scattering in every direction.

"Newly hatched birds may be found all summer, and incubation goes on from, say, early in May until the middle of August. Not that any single pair are engaged so long, but that different broods may be hatched during all this time. A greater number of old birds pair in April, and hatch their first brood some time during the following month. Most of them doubtless raise another. Others appear to defer incubation for 
a month or two, and have but one brood. The first chicks that I saw in the summer of I 865 were hatched in May, and I found others the same year only a few days old in August; but by this month almost all the birds of the year were well grown, and by September were in condition to offer legitimate sport. In October a few are found not yet ready to be shot; but the great majority are as large as the parents, and nearly as strong of wing. The season may, therefore, be said to begin in October and continue into March; but birds should not be pursued later than the middle of this month, for although few birds, if any, actually mate before April, it is cruel, as well as injudicious, to disturb them while they are preparing to do so. The beginning of the pairing season may be known to be at hand when certain peculiar cries, different from any usually emitted during the fall and winter, are heard.

"These notes are a sign that the coveys are breaking up and mating is about to commence. They are analogous to the bobwhite of the eastern quail (Ortyx virginianus), and are uttered, as with that species, more particularly in the breeding season. The note is a loud, energetic, two-syllable whistle, delivered in a clear, ringing tone. It is difficult to write down intelligently, but, once heard, is not likely to be afterward mistaken, except for one of the cries of the black-headed grosbeak. It sounds to my ears something like the forcible pronunciation of the syllables killink, killink, indefinitely repeated, sometimes in a rising and sometimes with a falling intonation. The old cocks, if they can be 


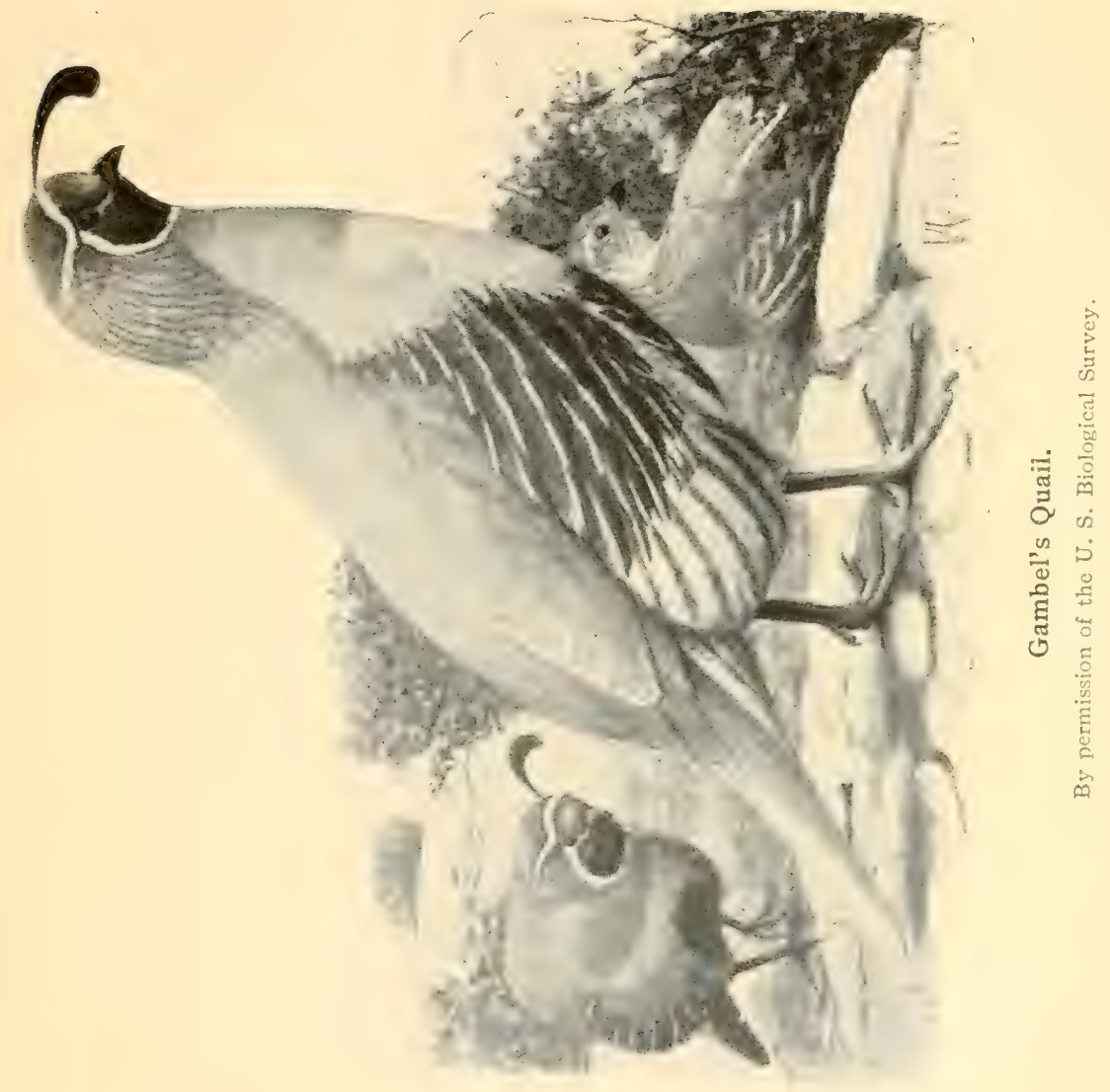



seen so engaged, are found strutting along some fallen log or gesticulating from the top of some broad rock or stepping with dignified air along the pathway under the bushes; sometimes even perched in a tree or bush, without other motion than the heaving of the chest; but wherever they may be, they have one mind in common, their only thought to secure the admiration and then the favor of birds more modest if not more fair.

"A beautiful sight it is to see the enamored birds pressing suit with all the pomp and circumstance of their brilliant courtships-the firm and stately tread, with body erect, of comely shape, displayed to best advantage; the quivering wings, the motion of the plumes, that wave like the standard of knights errant, the flashing eyes-bespeak proud consciousness of masculine vigor. The beautiful bird glances defiance, and challenges loudly, eager for a rival; but none disputes, and he may retire, his rights proven. Only a gentler bird is near, hidden in a leafy bower, whence she watches, admiring his bearing, fascinated by the courage she sees displayed, hoping every moment that the next will bring him, dreading lest it may. As their eyes meet she trembles, and would turn to fly, but cannot; his glow again, but with a different light, even more intense than before. With an exultant cry he flies straight to her, and, like the true knight he is, for just one instant bends till his breast touches the ground, and is then erect again. He leans toward her, half spreads his wing over her, and pleads in an undertone. She 
listens, but draws away; she listens, but only stands irresolute; she listens, and, listening, yields.

"They must prepare for new duties. With deep sense of responsibility and earnest solicitude the pair now cast about for a suitable spot for their home. They search through the tall, rank herbage alongside the stream, through the willow copses, among fallen mosscovered logs that are scattered around the glen, and at length make up their minds. Little more is needed than to fix upon the spot, for the nest is a simple affair, the work of a few hours, perhaps, scratching a suitable depression and lining it with a few dried grasses pressed together. Day by day eggs are laid, till a dozen or more fill the nest. They cannot be distinguished from those of the California quail. They measure an inch and a quarter in length by an inch in breadth, and are almost pyramidal in shape, the larger end flattish and very broad, the other narrow and pointed. The color is a buff, or rich cream, dotted and spotted all over with bright brown, and splashed here and there with large blotches of the same. When the female is not pressed to lay, the pair ramble about together in close company until the complement is finished. Then she gives up all recreation, grown already quite sober and maternal, and resolutely sets about her long tour of duty. But she is not forgotten because she can no longer share the idle pleasures of her lord. Mounted on a stump or bush near by, he stands watch, and continually solaces her with the best music he can make. It is not very harmonious, to be sure; in fact, 
his ditty at such times is a medley of odd notes, sounding rather lugubrious than hilarious, but it is presumably satisfactory to the one most concerned. So the long days pass, for two weeks or more, till feeble cries come from the nest; the mother dries and cuddles the curious little things, and the delighted birds, brimful of joy, lead their family off in search.of food.

"From the number of eggs sometimes found in a nest it becomes a question whether birds, hard pressed, may not occasionally deposit in nests not their own. We have no positive evidence that it may occur, but observation has rendered it highly probable, and such is the case with some other birds, as the rails and, I think, the Virginia quail. However this may be, it is pretty certain that broods of young sometimes coalesce at a varying time after hatching. I do not remember to have myself seen a covey of more than twenty, but it is currently reported upon good authority that troops numbering as many as fifty partly grown birds, and including several old ones, may be met with. This raises, of course, the question of polygamy, so common in birds of this order, and something may be said in favor of the view. The same surmise has been made in the case of $L$. califormicus, but I believe it remains to be proven. I am bound to observe that I have never witnessed anything supporting this view. ...

"Man is, I suppose, the quail's worst enemy; what the White does with dog and gun the Red accomplishes with ingenious snares. The Indians take great numbers alive in this way, for food or to trade with the 
whites along the Colorado, and they use the crests for a variety of purposes that they consider ornamental. I saw a squaw once who had at least a hundred of them strung on a piece of rope-yarn for a necklace. But the birds have other foes : the larger hawks prey upon them, so also do the wolves, as I had good evidence upon one occasion, when hunting in a precipitous, rocky place near Fort Whipple. I heard a covey whispering about me as they started to run off in the weeds, and followed them up to get a shot. They passed around a huge boulder that projected from the hillside, and then, to my surprise, suddenly scattered on wing in every direction, some flying almost in my face. At the same instant a wolf leaped up from the grass where he had been hiding, a few feet off, intending to waylay the covey, and looking very much disappointed, not to say disgusted, at the sudden flight. We had marked the covey together, and were hunting it up from opposite sides, and neither of us could account for their flushing so unexpectedly. Then he caught sight of me, and it was a question which of us was most surprised. However, I felt that I owed him a private grudge for getting in the way of the birds and spoiling my shot, so I fired both barrels in quick succession. With nothing but mustard seed in my gun, I hardly expected to more than frighten the beast, but he was so near that he rolled over quite handsomely, his hindquarters paralyzed with the charge, which took effect in the small of the back. I kept his skin as a trophy, and since that time have had unlimited confidence in small shot." 
This account was written, I believe, as long ago as 1872 , or 1873 , but it remains the best description of Gambel's partridge that has been writtten.

The birds appear to be as numerous in their range as ever they were, and with the increase of water which goes with the progress of irrigation in Arizona and New Mexico they are likely to increase still further. Captain Bendire cites an observation of Mr. Herbert Brown, of Tucson, Arizona, which shows that the Gila monster (Heloderma) eats the eggs of this species. 


\section{MASSENA QUAIL.}

\section{Cyrtonyx montezunce mearnsi.}

This handsome and highly-colored bird is of the southwest, and until very recently has never been pursued for sport, though often killed for meat. In appearance it is unlike any of our United States partridges, having large feet, a full, soft crest, and being more or less dotted below with large round spots of pure white. The sides of the head are marked with black and white stripes; the chin, throat, and a band across the fore neck, are all black; the crest is brownish; the upper parts are brown, barred and spotted with black and streaked with white, buff or reddish. The wing quills are spotted with white on their outer webs, while the thighs, belly and under tail coverts are black. The flanks and sides are lead-color, marked with many round spots of pure white, and the middle line is chestnut. The female is paler everywhere, but has the upper parts streaked and barred as in the male. The head lacks the distinctive white and black stripes, and the sides are slightly barred with black. Length, $8 \mathrm{~T} / 2$ to 9 inches; wing, about 5 , or a little more. This quail is found in western Texas, New Mexico, Arizona, and well down into western and central Mexico. The typiI06 
cal montezuma and other species occur in Mexico. One found in Guatemala and southern Mexico has the flanks chestnut instead of lead-color.

This bird was described as long ago as I830, yet for many years thereafter little or nothing was known about it, and it was only in I8go that the eggs were found and described.

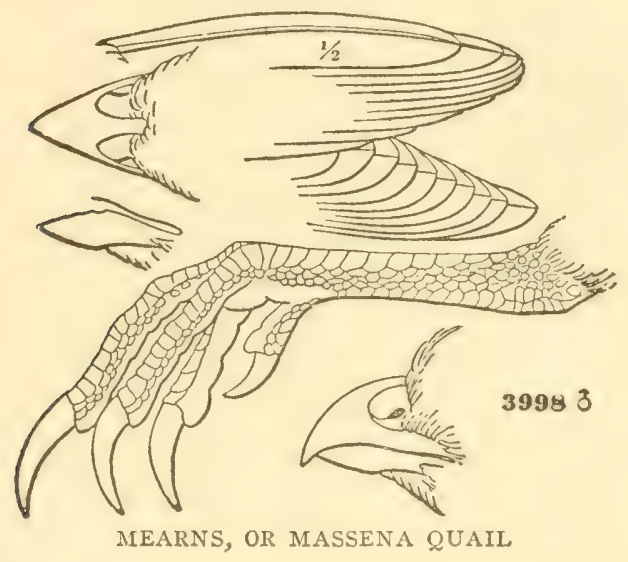

The Massena quail, or, as it is now called, the Montezuma quail, is notable for its odd and beautiful coloring and for its extraordinary simplicity and lack of suspicion, a quality which is reflected in the name "fool quail," given it in some sections. This title, commonly enough applied to certain unsuspicious grouse and quail, is an unintentional testimonial by man to his own bloodthirstiness, declaring in effect that any bird or animal must be a fool that does not know that civilized 
man is a natural butcher. It takes wild things some time to realize that there are no gentle men, and obviously this lesson is learned more slowly by birds or animals living in places unfrequented by man than in regions where he is more numerous. Even the ruffed grouse, which, in thickly settled regions, is the wisest, wildest and most wary of birds, is in some localities so unafraid that the passer-by who will tie a noose of cord on the end of a six-foot pole, may pass the loop over the bird's head and drag it from its perch.

The Mearns quail is reported to be less graceful in carriage and less elegant in shape than some of its relatives which inhabit the same region, but may not this be only another way of stating that it is unsuspicious and not easily alarmed? The wariest of gallinaceous birds, if ignorant of the presence of an enemy, carries its feathers more or less loosely, walks with a short neck, and has a rounded back, thus presenting an appearance very different from the same bird when it is startled or alarmed and about to take to flight. Then the neck is stretched upward, the bird stands high on its legs, all its feathers are pressed close to its body, its crest is raised, and it stands there alert and prepared to dart away at a second's warning.

In Texas this bird is known as the black quail, or the black-bellied quail, while, as said, in Arizona, on account of its gentle nature it is called fool quail. It is said to frequent rocky ravines heading well up into the mountains, but of recent years has come to the ranches, and is found feeding in the green fields. Cap- 


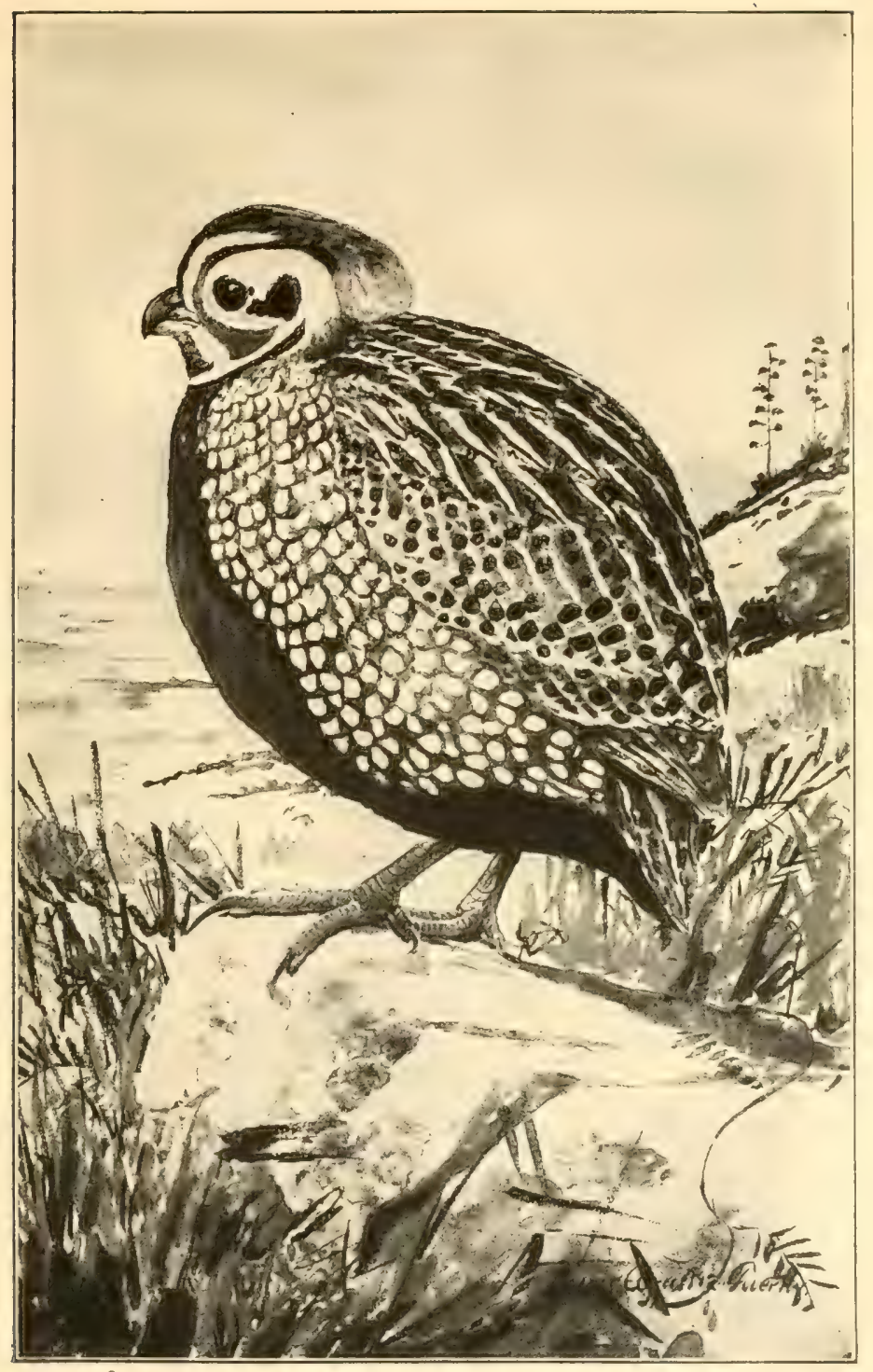

Mearns' Quail. 

tain Bendire says that in Mexico he has several times seen them living contentedly in cages.

Capt. W. L. Carpenter saw the Massena partridge in the Rio Grande Valley, near Taos, Mexico, and on the headwaters of the Black and White rivers, where he believed it bred. In the breeding season, in Arizona, they are said to frequent live-oak scrub and patches of rank grass, at an altitude of seven to nine thousand feet. "Here," according to Mr. John Swinburne, writing to Captain Bendire, "they are summer residents, only descending to much lower altitudes in winter. They lie very close at all times, allowing one to almost step on them before they move. I have seen this species on the White Mountains during the breeding season, and saw young birds of the year shot there. Even the adults seemed very stupid when suddenly flushed, and after flying short distances would alight and attempt to hide in most conspicuous places. I have seen men follow and kill them by throwing stones."

Captain Bendire also quotes Mr. G. W. Todd, as follows :

"I first met with the Massena partridge in Bandera County, Texas, in 1883 , where they are very scarce, and I learned but little of its habits for a long time. They are very simple and unsuspicious, and apparently live so much in barren and waste places that they do not see enough of man to make them afraid. On seeing a person they generally squat at once, or run a little way and hide. They will hardly fly until one is almost on them, but when they finally do fly they go much 
further than either the Texan bobwhite or the scaled partriclge, and on alighting they run rapidly for a little distance and then squat again, generally flushing easier the second time. It is rare to see more than six together; two or three are more often met with. In the fall of I886 I found a covey of five, on a wet and misty day, and killed three of them with a Winchester rifle before the remaining two flew. I never found their eggs nor met with small young until this year. I saw but a single bird this season, and this seemed to be entirely alone. They are not very abundant here, and are always found in the most barren places, among rocks and wastes where even prickly pear is stunted and no bush grows over three feet high. When scared they utter a kind of whistling sound, a curious combination between a chuckle and a whistle, and while flying they make a noise a good deal like a prairie hen, though softer and less loud, like chuc-chuc-chuc, rapidly repeated.

"The only nest of this species I have ever seen was situated under the edge of a big bunch of a coarse species of grass, known as 'hickory grass.' This grass grows out from the center, and hangs over on all sides until the blades touch the ground. It is a round, hardstemmed grass, and only grows on the most sterile soil. According to my observations, the Massena partridge is seldom seen in other localities than where this grass grows. I was riding at a walk up the slope of a barren hill, when my horse almost stepped on a nest, touching just the rim of it. The bird gave a startled flut- 
ter, alighting again within three feet of the nest, and not over six feet from me; then she walked away with her crest slightly erected, utering a low chuckling whistle, until lost to view behind a Spanish bayonet plant (Yucca) about thirty feet off. I was riding a rather unruly horse, and had to return about thirty yards, to tie him to a yucca, before I should examine the nest. This was placed in a slight depression, possibly dug out by some animal, the top of the nest being on a level with the earth around it. It was well lined with fine stalks of wire-grass almost exclusively, the cavity being about five inches in diameter and two inches deep. At the back, next to the grass, it was slightly arched over, and the overhanging blades of grass hid it entirely from sight. The nest was more carefully made than the average bobwhite's nest, and very nicely concealed."

The food of the Massena quail, in western Texas and New Mexico, appears to consist of small bulbs, to secure which the birds often dig or scratch out holes to the depth of two inches. In the mountains they also eat acorns, mountain laurel, tubers of nut grass, cedar and other berries.

The nest is likely to be built on a hillside, sometimes well hidden, and often sunk quite deeply in the ground. The eggs seem to run from 8 to Io in number. They are pure white in color, and, while often glossy, are sometimes more or less rough and granulated.

As already stated, the Massena quail is scarcely pur- 
sued for sport, and on this point Mr. Herbert Brown, of Tucson, Arizona, writes me as follows:

"The Massena quail, or, as it is now called, Montezuma quail, will lie well to a dog, but, practically speaking, they are not hunted as a game bird; in fact, not hunted at all. They are mountainous in their habits, and are not commonly killed.

"This bird, among the Mexicans, is known as 'guinea,' and also as 'chacalaca.' The latter word is commonly applied to persons of garrulous or talkative dispositions. As the male bird, when strutting among the females, keeps up a continual clatter, the Mexican people, with their readiness for characterization, call them 'chacalaca.'

"It is among the most peculiar of our game birds, and I much regret that it is so little known. Of all the quail it is the most easily domesticated. Some years ago a young female was sent to me from Sonora. As I then had no means of keeping it, I gave it to a friend. It was raised about the house, and was as tame as a pet chicken. A swinging door led into the kitchen, and it was always careful to await its opportunity, and make its run through as the door swung open. Some years ago I heard of a small bunch on the Sonoita that fed regularly with the chickens at the ranch house. At a ranch house on the Sopre two adult birds took up with the chickens, and in the spring following raised a brood of little ones, some four or five of which grew to maturity. Eventually they fell into disfavor and were driven away or killed. This was due to the pugnacity 
of the male bird. They appeared to have no use for the chickens, and were continually fighting them without provocation. The big ones could stand it, but the little ones were the sufferers." 


\title{
THE AMERICAN GROUSE
}

\author{
Tetraonida.
}

The differences between the American grouse and quail have been pointed out in two earlier chapters, but, nevertheless, may be repeated here. The feet of all the grouse are covered with hair-like feathers. In this group a tuft of small feathers runs forward from the forehead along each side of the bill and covers the nostrils, while in the quails the nostril is naked and is protected by an overhanging scale. All the grouse have on head over the eyes narrow patches of naked skin, and most or all of them have on the sides of the neck bare patches, which are often inflatable.

The pectinations on the toes of the grouse are shed annually. Mr. Manly Hardy of Brewer, Me., informs me that in the ruffed grouse the whole scaly envelope of the foot is shed each year.

The grouse are usually large birds, while the quail are small, and in the grouse the tail is usually long, while in all the quail it is short.

The outline drawings, showing the bill, foot, wing and tail of the various grouse and quail will assist those who desire to learn these characters. 


\title{
DUSKY GROUSE.
}

\author{
Dendragapus obscurus. \\ Dendragapus obscurus fuliginosus. \\ Dendragapus obscurus richardsoni. \\ Dendragapus obscurus sierre.
}

The dusky grouse is the largest of the American wood grouse, sometimes weighing four pounds. Above, the male is dusky gray or dull black, usually more or less waved with fine, blacker lines. Sometimes there is a variety of light and dark color on the back and wings, producing a mottled effect. The tail is black with a gray band across the end, usually from half an inch to an inch wide. The under parts are slaty graty, somewhat streaked with white on the flanks. The bird is from twenty to twenty-three inches long, and is stout and graceful. On the side of the neck there is a patch of white surrounding a naked, inflatable bare space which is hardly, or not at all, to be seen, except during the breeding season. The throat is also white or very pale.

The much smaller female is grayish or brownish in color, marked with spots and bars of blackish.

This is the typical dusky or blue grouse, and is found in the Rocky Mountains, west as far as they extend, east to the Black Hills, south to the Mogollon 
Mountains of western New Mexico and the White Mountains of middle eastern Arizona. The sub-species, known as the sooty grouse, is found on the northwest coast in the region of great precipitation, north to

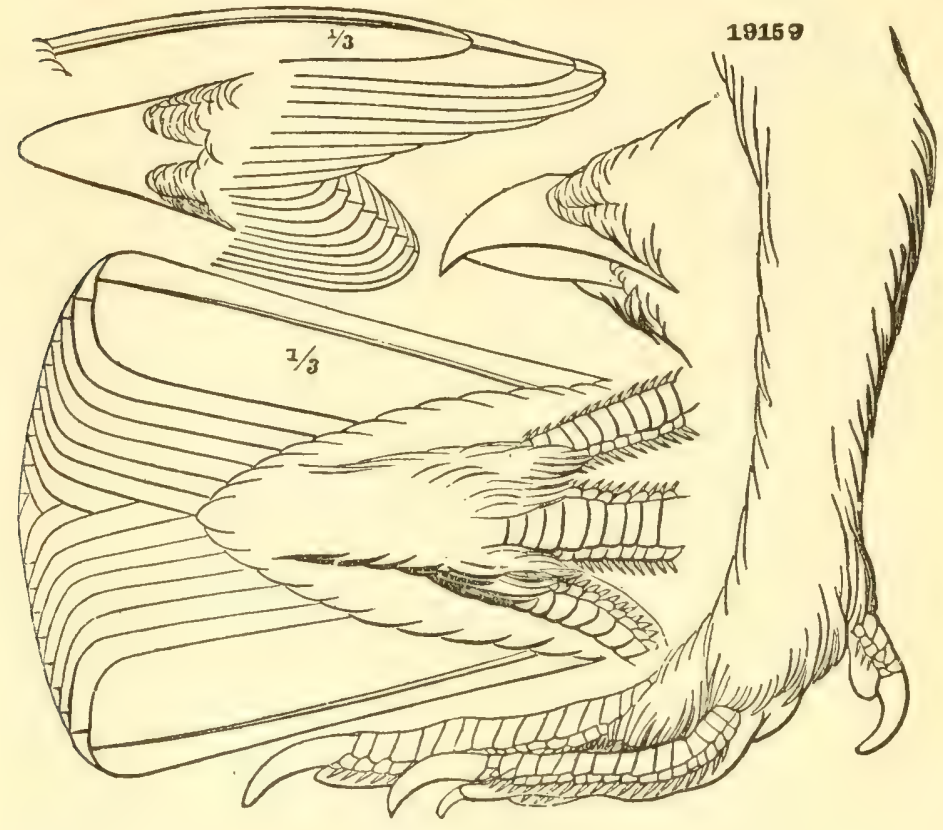

DUSKY GROUSE

southern Alaska and southern Yukon. It is darker colored, with a narrower tail band, lacks the whitish space on the side of the neck and has the throat darker. Often or usually the scapulars or shoulder feathers are without distinct white streaks or spats. 
The adult female is much darker than the typical dusky grouse, and often has the upper parts distinctly reddish, instead of being merely gray or buffy.

Richardson's grouse, found in the northern Rocky Mountains, has the tail without the terminal band of gray; otherwise it is much like the dusky grouse, but usually the tail feathers are broader and the tail more even. There are certain places in the Rocky Mountains-for example, in northwestern Montana-where the dusky grouse and Richardson's grouse intergrade, and often it is impossible to say to which form a specimen belongs. In this latter region the female is often gray, black mottled, with little or no tinge of buff.

The sierra grouse, with a narrower tail band than the typical form, is found in the region from Fort Klamath, Oregon, south, through the mountains of California, to Mount Piños, near old Fort Tejon.

The dusky grouse, although not at all known by eastern sportsmen, is yet easily the finest of our American species. It is exceeded in size only by the sage grouse, but in beauty, in edible qualities and in the sport it furnishes it far excels that species.

The dusky grouse is found in all the mountain regions of the farther West, from Alaska south as far as the White Mountains of Arizona. Naturalists separate it into four forms, as given above; but in habits, and in the qualities which interest the gunner, all are much alike. It is not a migratory bird, but remains essentially in one locality throughout the year, although, like many mountain-dwelling birds and mam- 
mals, the altitude at which it lives changes with the changing season.

One of the earliest spring sounds in the country where the dusky grouse are found is the hooting of the male, a booming or blowing sound analogous to the grating song of the sage grouse or the tooting of the pinnated grouse. The call possesses a certain ventriloquial quality, which makes it exceedingly difficult to follow, and it is often hard to locate the bird that is uttering it. A similar difficulty is usually found in attempting to follow up the drumming of the ruffed grouse. This call and the accompanying mating actions were well described by a correspondent, "Standstead," in Forest and Stream twenty years ago. He wrote: "While driving near the city. [Victoria, B. C.] with the veteran shot, R. Maynard, we saw a pair of blue grouse quite near the trail, and the cock bird gave us a most entertaining exhibition of the charms that he displays in wooing his mate. Like a turkey cock he strutted about with his wings trailing on the ground, his tail feathers erect and spread out fan-like to their fullest extent, his neck distended, and on each side of his neck the feathers were turned out so as to resemble a pair of round white rosettes, nearly three inches in diameter, with an oblong red spot in their center, where the skin of the neck was exposed. His head seemed to be crowned with a fiery red comb. Excepting the rosettes, he was in appearance a miniature turkey gobbler. Every few seconds he would strut up to his demure but sleek-looking mate, puff out his neck and 


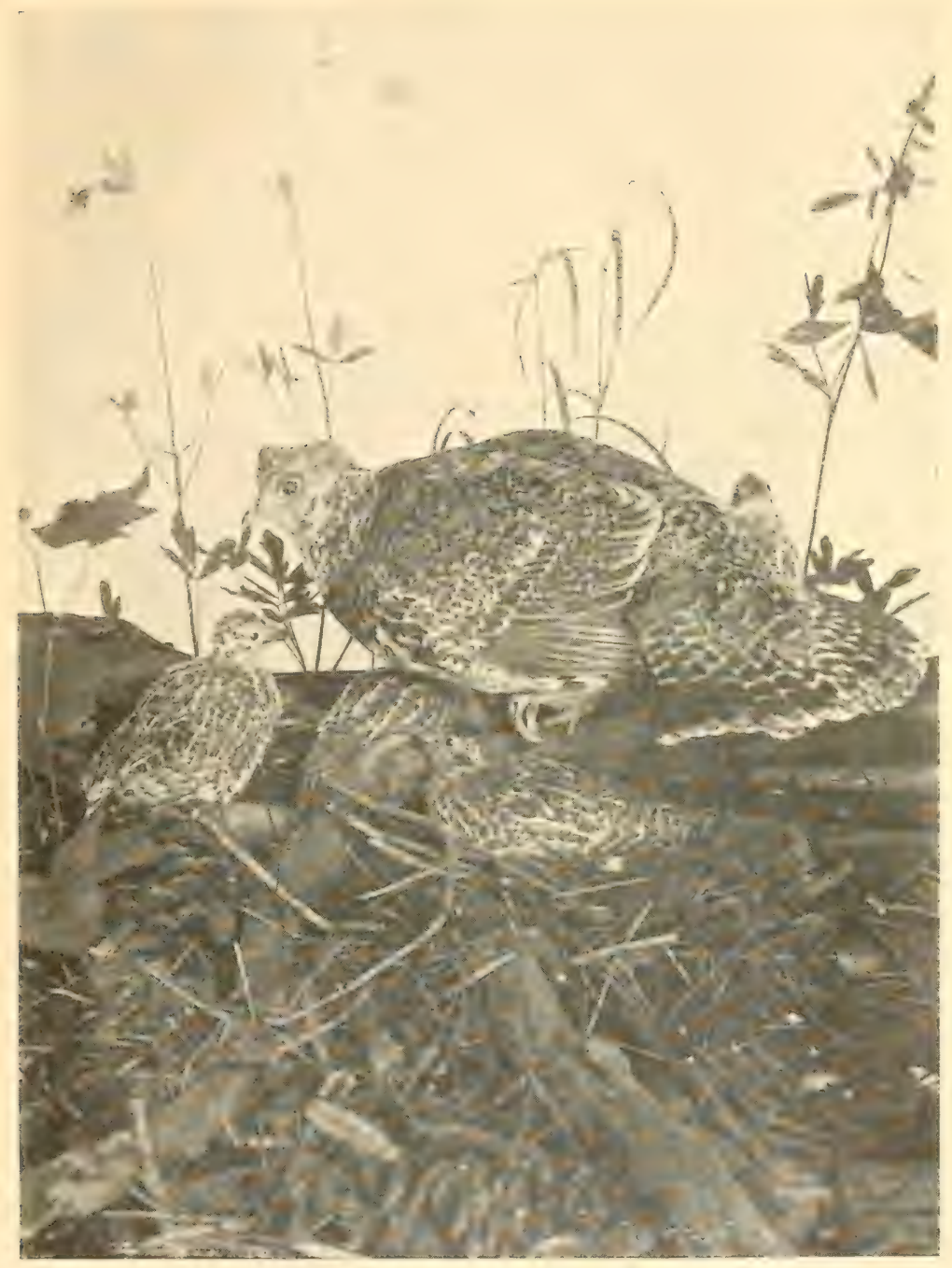

Sierra Dusky Grouse and young.

From group in American Museum of Natural History. 

with a jerky movement of his head utter his boom, or hoot, boom-boom-boom. As he grew more and more demonstrative in his actions, his modest mate flew up to an overhanging limb to escape his familiarities, and we drove away, leaving him still strutting on the ground underneath the tree where his mate sat perched."

Another writer refers to the sound uttered at this season by the male dusky grouse as "growling" or "groaning," and notes, as have many others, the peculiarity that when near it often seems quite distant, and when distant it sometimes seems near, appearing to come from every direction but the true one.

The female usually makes her nest in the open at the foot of the mountains, quite a little, way from the timber, perhaps under some little clump of brush at the foot of a steep bluff, partly clad with pines, or perhaps among the aspens in some mountain valley. The eggs vary in number from seven to fifteen, and perhaps are oftenest nearer the smaller number. They are buffy in color and are usually more or less thickly spotted with fine dots of reddish brown or even chocolate. These dots and spots are usually quite distinct and seldom or never run into blotches and cloudings, as is usually the case with the eggs of the ptarmigan.

After the nest is constructed and the eggs are laid, the male leaves his mate and by slow stages betakes himself to the mountain-tops, where, in midsummer, old cocks and barren hens are found in the extreme edge of the timber, and very often on the alpine mea- 
dows and amid the rocks above timber line. The female all through the summer, leads her brood of little ones about where insects, berries and seeds are most accessible. Like many other grouse, if her young are closely approached she feigns to be hurt, and runs off with dragging wings and seemingly feeble footsteps to lure the enemy to pursue her; but, after she has been followed for a little distance, takes wing and flies off up the mountain, to return on foot when the danger is past. By the middle of July the young are usually somewhat larger than quails, and at this time, instead of immediately hiding when approached, they take wing for a short flight, and, immediately on reaching the ground, hide, lying as close as any birds that I have ever seen. At such times, if the ground be fairly open, it is not difficult to see them as they crouch close to the earth, but as soon as they recognize that your eye has caught them, they spring into the air for another flight. I recall one morning when, traveling along a little valley, with a companion, we started several broods of well-grown young, of which we killed seventeen by shooting their heads off with our rifles. The birds were needed for food for the camp.

As the young birds grow larger and more hardy, the mother leads them higher up the mountain, and by the end of August or first of September they are feeding among the green timber, at which time their principal food in some localities is a species of lowgrowing red huckleberry. By September or October the birds are nearly as large as the parent, and long be- 
fore this it is their practice when disturbed to fly up into the branches of the pines, where they stand erect with feathers pressed close to their bodies, each looking for all the world like a broken-off dead branch.

Often in August or September broods of these birds may be found on the bare mountain-side, feeding on the huckleberries, or among low sarvis trees. In such a case splendid and very easy shooting may be had at these great birds, but if a flock be scattered in the timber, or among thick alders, the shooting is quite as difficult as that of the eastern ruffed grouse. Although these birds can know little about the shotgun, they are often quite as acute as the partridge in putting the trunk of a tree or a clump of bushes between the gunner and themselves. On the other hand, when they take refuge in the branches of a tree, and stand there watching you, they will often permit half a dozen shots to be fired at them without moving, unless hit.

In Captain Bendire's admirable account of the sooty grouse, the northwestern form of D. obscurus, he quotes a letter from Captain (now General) T. E. Wilcox, in which the writer says: "I once caught a mother grouse with a fish hook. I had my rod on my shoulder and suddenly came upon a covey about the size of quails and caught one with my hands. This made the old bird frantic; she attacked me, and alighting on my rod, the hook pierced her foot. I was pulling her in when my leader broke and she flew off. Of course, I released her chicken. I killed a male in the Boise Mountains, December 2, 1879, which 
weighed three pounds ten ounces; but some killed by me in the Cascade Mountains seemed to be much larger. While on Lake Chelan in I883, hunting white goats, I flushed a covey of grouse and here heard for the first time the call note of the female for her young. It was low, but distinct, something like that made by the bobwhite just before it flushes. At this time, the last of August, the birds were well grown. I have always found these birds near water. In $188 \mathrm{I}$, while going to Indian Valley, Idaho, I rode past some, one being near enough to touch with a switch I had in my hand, yet they all walked out of the trail as quietly as domestic fowls would have done and then resumed their dusting."

Richardson's grouse, the form of the dusky grouse found in the northern Rocky Mountains from southern Montana, north far into British America, resembles in habits the other forms and is quite abundant. About the Continental Divide, specimens are sometimes seen which show approach to obscurus, or to the sooty grouse. In many places, where seldom disturbed by man, they are exceedingly gentle and unsuspicious, and a brood will walk slowly along before one, feeding and calling to one another in a particularly innocent and attractive way.

It is stated that the birds spend their winters largely among the branches of the pine trees, and that they feed to a very great extent on the pine needles.

Mrs. Florence Merriam Bailey says of the winter habits of the dusky grouse in New Mexico: 


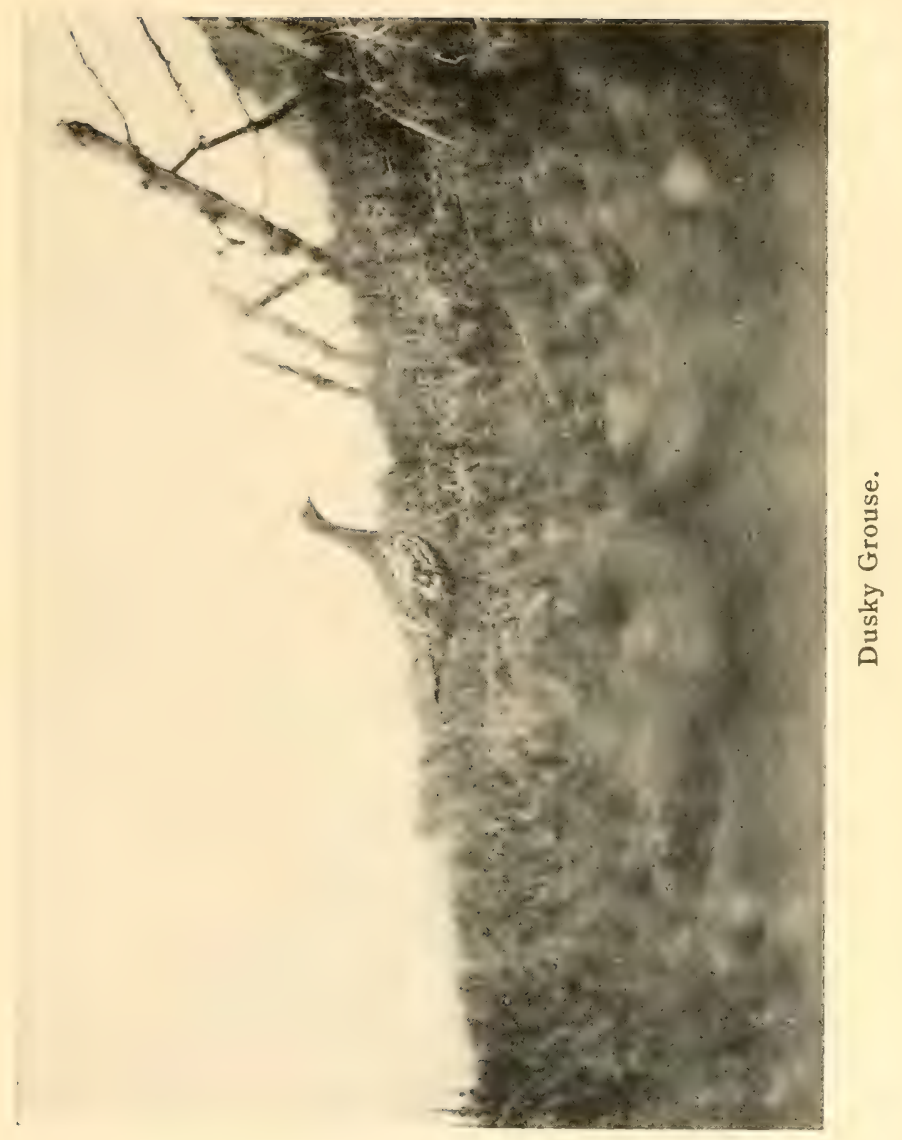



"Near our camp by the foot of Pecos Baldy, Mr. Bailey discovered a winter roosting tree of the grouse. The tree was on a sheltered part of the wooded slope and was so densely branched that after a prolonged rain the ground beneath was perfectly dry. The earth was strewn with winter droppings, composed entirely of the leaves of conifers. Conifer needles had also been eaten by three of the grouse that were taken ... in July and August, but at this season the birds were living principally on such fresh food as strawberries, bearberries (Arctostaphylos uva-ursi), sheperdia berries, flowers of the lupine and paint brush, seeds, green leaves, grasshoppers, caterpillars, ants and other insects. But one crop contained twenty-seven strawberries, twenty-eight bearberries and twelve sheperdia berries, besides flowers, leaves and insects, while the accompanying gizzard was filled with seeds, green leaves and insects."

In some sections of the West the dusky grouse are reported to pack in the autumn, forming very large flocks, but I havc never seen anything of the kind. Usually, in my experience, only the members of a single brood, ranging in numbers from eight to twenty, are found together. Sometimes, however, in summer, on the high peaks, flocks of a dozen old males are found associated together.

It is said that in Colorado and parts of Montana, where grain is grown adjacent to the mountains or the timber occupied by the dusky grouse, the birds are frequently found feeding on the stubble fields. If this 
is the fact they must give great shooting in such situations.

It is readily conceivable that this bird might be introduced into the mountains of the Eastern Statesfor example, in New England, Pennsylvania, Virginia and North Carolina, and in these sections, if for a time protected, might establish itself. In the West it is usually found at altitudes much higher than these, though, in summer, females and young broods of the dusky grouse inhabit essentially the same territory as the ruffed grouse.

The dusky grouse has but three vernacular names commonly in use-blue grouse, pine grouse and gray grouse. Dusky grouse and blue grouse are the two most common. 


\title{
CANADA GROUSE, SPRUCE PARTRIDGE.
}

\author{
Canachites canadensis. \\ Canachites canadensis osgoodi. \\ Canachites canadensis canace.
}

Two small wood grouse, notable for their extreme simplicity and lack of fear of man, are found in the evergreen country, Canadian life zone, of the east, north and west. Of these the first is the Canada grouse, a small, blackish bird, variously marked below with spots of white and with the tail tipped with rusty reddish. The male above is black, waved with dark gray, and beneath black; its throat bordered with white, many of the feathers tipped with white; the sides and the flanks marked by long white streaks. The female is barred with black and rusty, but has the sides and the scapulars or shoulder feathers streaked with white. The tips of the tail feathers are bright rusty. Length, I $4 \frac{1}{2}$ inches; wing about 7 inches and tail 5 inches. It is found in northern New England, New York, Michigan, Minnesota and through Canada to Alaska.

The three forms of the Canada grouse are very closely related, and, from the sportsman's viewpoint, hard to separate. True canadensis is restricted to the northern part of the range-eastern flanks of the Rocky Mountains west of Edmonton, Alberta, easterly to Labrador Peninsula, and Alaska from Bristol Bay 
to Cook Inlet and Prince William Sound; osgoodi to Mount McKinley Range and Yukon region, east to Great Slave and Athabaska Lakes; canace to Manitoba, southern Ontarin and New Brunswick, south to northern Minnesota, IVisconsin, Michigan, New York and New England. Another race, atratus, has been described from the coast region of Alaska.

The Canada grouse is not a familiar bird to the

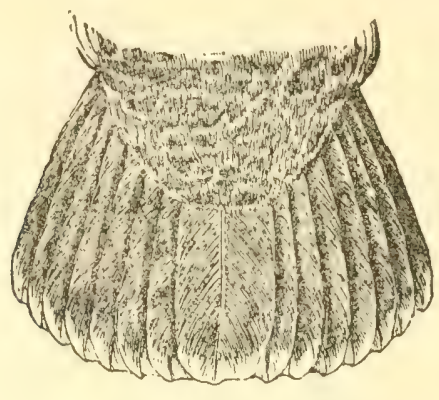

TAIL OF CANADA GROUSE

sportsman, and is scarcely ever shot over dogs, but the angler and traveler through the wilderness of the North often meets it in the depths of the forest. There is little to be said about shooting it, but in its life history there is much that is worth recording. Most of this has already been written down in works on natural history, but as many of these are not easily accessible to sportsmen, it is well to repeat some of these facts.

This is one of the most unsuspicious and least fearful of man of all the grouse. Often it may be killed by stones or sticks thrown at it, or a noose of twine 
tied to the end of a stick may be passed over its head as it sits on a limb, and it may thus be dragged from its perch. A bird of such confiding disposition would not afford much sport, and besides this the deep forests which this species inhabits are far from the usual haunts of the gunner.

The range of the Canada grouse extends from northern New England, north through Labrador, west to northern Minnesota and northwestward to Alaska. We have seen them on the shores of Prince William Sound and Cook Inlet in that territory. Its northern limit, according to Swainson, extends to the parallel of $67^{\circ}$. It is not migratory, and breeds wherever found, and its favorite home is in the dense swamps and evergreen thickets of the north land. It is upon the buds and leaves of these evergreens that it chiefly feeds, and from this food its flesh often takes a resinous taste that is not agreeable.

The breeding season is in May or June, according to latitude. The mating actions of the male-his drumming-differ much from those of other grouse. Major Bendire quotes a correspondent as saying: "After strutting back and forth for a few minutes the male flew straight up as high as the surrounding trees, about fourteen feet; here he remained stationary an instant, and while on suspended wing did the drumming with the wings, resembling distant thunder, meanwhile dropping down slowly to the spot from where he started, to repeat the same thing over and over again."

Mr. Everett Smith says in Forest and Stream: "The 
Canada grouse performs its drumming upon the trunk of a standing tree of rather small size, preferably one that is inclined from the perpendicular, and in the following manner: Commencing near the base of the tree selected, the bird flutters upward with somewhat slow progress, but rapidly beating wings, which produce the drumming sound. Having thus ascended fifteen or twenty feet, it glides quietly on wing to the ground and repeats the maneuver. Favorite places are resorted to habitually, and these drumming trees are well known to observant woodsmen. I have seen one that was so well worn upon the bark as to lead to the belief that it had been used for this purpose for many years. This tree was a spruce of six inches diameter, with an inclination of about fifteen degrees from the perpendicular, and was known to have been used as a drumming tree for several seasons. The upper surface and sides of the tree were so worn by the feet and wings of the bird or birds using it for drumming, that for a distance of twelve or fifteen feet the bark had become quite smooth and red as if rubbed."

Major Bendire quotes Manly Hardy as saying: "My father, who had opportunities to see them drumming, told me they drum in the air while descending from a tree. They would fly up on a tree and then start off and drum on their way to the ground like a Quaker grasshopper. When on the ground they scratch a great deal more than other grouse do." 
Thus there seems to be a wide individual variation in the practice of this nuptial performance.

The number of eggs laid by the Canada grouse varies from nine to thirteen, though rarely two or three more may be found in a nest. The ground color of the eggs is buff, and they are irregularly spotted and blotched with reddish brown, which sometimes is very dark. Specimens are rarely seen with few or no markings.

A number of years ago, Mr. Watson L. Bishop, of Kentville, Nova Scotia, was successful in domesticating some Canada grouse, and he contributed to Forest and Stram many interesting observations on the habits of these birds in confinement. He says: "As the nesting season approaches I prepare suitable places for them by placing spruce boughs in such a way as to form cozy little shelters, where the birds will be pretty well concealed from view. I then gather up some old dry leaves and grass and scatter it about on the ground, near where I have prepared a place for the nest. The bird pays no attention to this until she wants to lay. She will then select one of these places, and after scratching a deep cup-shaped place in the ground, deposit in it her eggs. When the hen is on the nest she is continually making a kind of cooing sound, which I have never heard them make on any other occasion. If there should be sufficient material within easy reach of the nest, the bird will sometimes cover the eggs up, but not in all cases.

"No nesting material is taken to the nest until after three or four eggs are laid. After this number has 
heen deposited, the hen, after laying an egg, and while leaving the nest, will pick up straws, grass and leaves, or whatever suitable material is at hand, and throw it backward over her back as she leaves the nest, and by the time the set is complete, quite a quantity of this litter is collected about the nest. She will then sit on her nest and reach out and gather in the nesting material and place it about her, and, when completed, the nest is very deep and nicely bordered with grass and leaves.

"So strong is the habit or instinct of throwing the nesting materials over the back, that they will frequently throw it away from the nest, instead of toward it, as the hen will sometimes follow a trail of material that will turn her right about, so that her head is toward the nest, but all the time she will continue to throw what she picks up over her back. This, of course, is throwing the material away from the nest. Discovering her mistake, she will then right about face and pick up the same material that an instant before was being thrown away, and throw it over her back again, toward the nest.

"The way they will steal eggs from one another would do credit to a London pickpocket. Two hens had their nests near together, perhaps two feet apart, and as each hen laid every other day, one nest would be vacant while the other would be occupied. The hen that laid last would not go away until she had stolen the nest egg from the other nest and placed it in her own. I once saw a hen attempt to steal an egg 


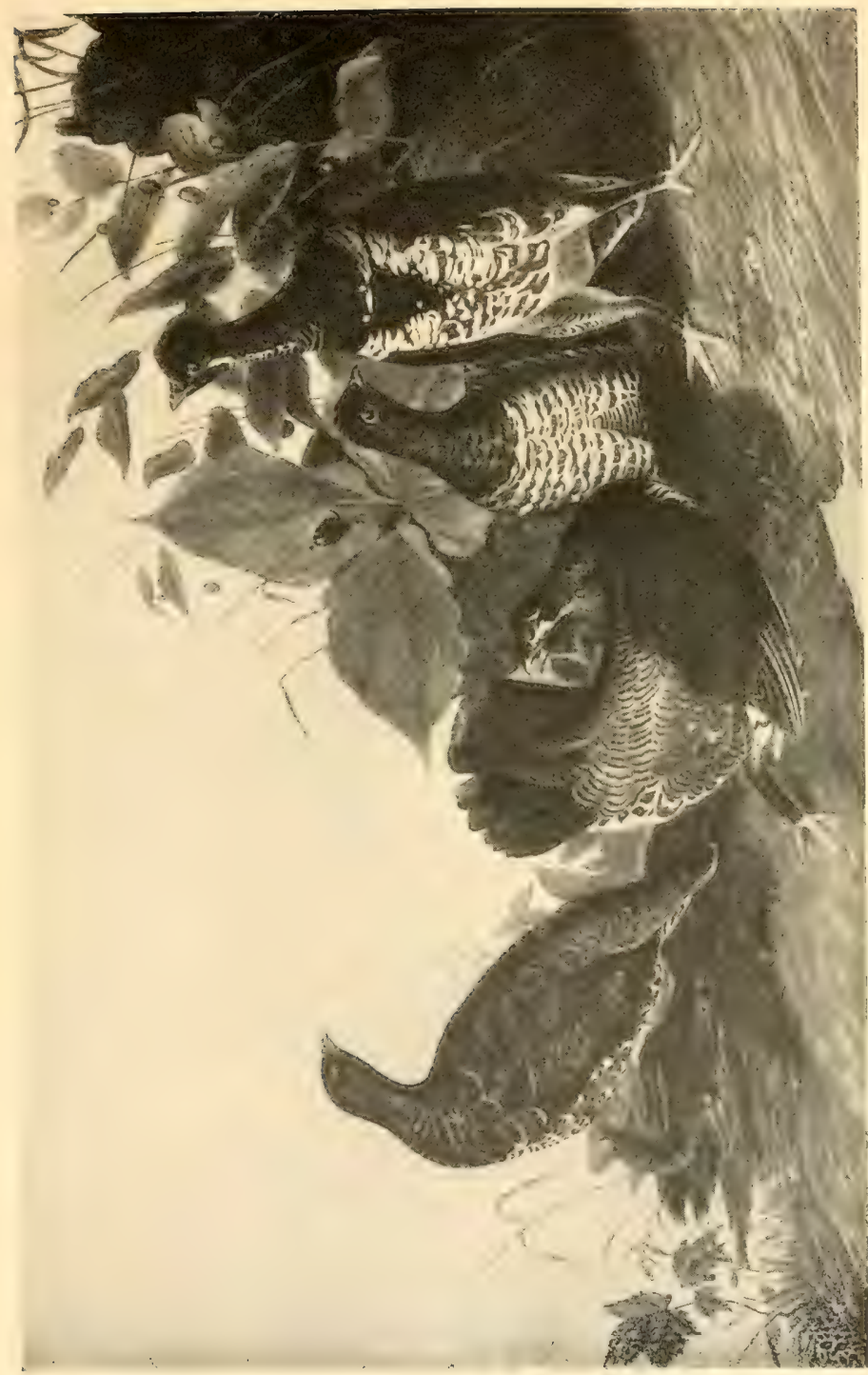

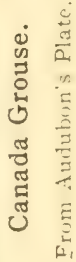



from another nest that was twenty feet away. She worked faithfully at it for half an hour or more, but did not succeed in moving the coveted egg more than about eight feet, it being uphill. The egg so frequently got away from her, and rolled back a foot or more each time, that she at last got disgusted and gave up the task.

"On going to the pen one evening I found one of the hens on the nest, and I knew she was beginning to set, as all the others had gone to roost. Slipping my hand under her, I found three eggs-the nest egg, the one just laid, and the one stolen from the other nest. I picked two of them up and held them before her, when she all at once placed her bill over the one held between my thumb and fore finger and tried to pull it out of my hand; I did not let her have it, however, and she immediately stepped upon the side of the nest, and placing her bill over the remaining ego, drew it up out of the nest and pushed it back out of sight, as much as to say: 'You have two, and that is all you can have.' I must confess that it was with great reluctance I took these eggs from her, she pleaded so hard for them.

"The male bird begins to strut in March. I remember very well the first time I saw one strutting. I had obtained the bird in the fall, and he used to sit about bunched up almost in a round ball, as the female did, until one morning, when I went to feed them, I found him strutting. His attitude was so different 
that one would scarcely have known it was the same bird.

"I will describe as nearly as I can his conduct and attitude while strutting. The tail stands almost erect, the wings are slightly raised from the body and a little drooped, the head is still well up, and the feathers of the breast and throat are raised, and standing out in regular rows, with the feathers of the nape and hind neck well back, forming a smooth kind of cape on the back of the neck. This smooth cape contrasts beautifully with the ruffled black and white feathers of the throat and fore breast. The red comb over each eye is enlarged, until the two nearly meet over the top of the head. This comb the bird is able to enlarge or reduce at will, and while he is strutting the expanded tail is moved from side to side. The two center feathers do not move, but each side expands and contracts alternately with each step as the bird walks. This movement of the tail produces a peculiar rustling like that of silk. This attitude gives him a very dignified and even conceited air. He tries to attract attention in every possible way by flying from the ground up on a perch, and back to the ground, making all the noise he can in doing so. Then he will thump some hard substance with his bill. I have had him fly up on my shoulder and thump my collar. At this season he is very bold and will scarcely keep enough out of the way to avoid being stepped on. He will sometimes sit with his breast almost touching the earth, his feathers erect as in strutting, and making peculiar nodding and 
circular motions of the head from side to side; he will remain in this position two or three minutes at a time. He is a most beautiful bird, and shows by his actions that he is perfectly aware of the fact.

"As the spring and summer advance, the food given these Canada grouse must be changed with the season, and it is only with a perfect knowledge of their wants, and with constant care, that they can be safely carried through the heat of the summer and the moulting season. In the nesting season the females are very quarrelsome, and at this time more than two or three cannot be kept in the same pen, but in July they may be all turned together again and they will agree very well until the following March."

The winter food of the Canada grouse is chiefly leaves and buds of spruce and tamarack. In spring, when insects make their appearance, no dot1bt they feed largely on them and on the leaves of various plants, while at the ripening of the berries these are eaten.

Little or nothing is said by writers generally about the gathering together of these birds in great flocks, yet, like many other species of our grouse, at certain seasons of the year they seem to unite in great companies. Major Bendire quotes Manly Hardy, of Brewer, Maine, as saying: "A Micmac Indian, whom I consider reliable, tells me of having seen a pack of many thousands, somewhere east of Halifax, Nova Scotia, on which their whole village lived for weeks, moving after them when they moved. The males sreatly preponderate over the females, at least two to 
one. They feed almost entirely on the needles of spruce and fir, also hackmatack and berries in summer. They show a preference for some fir trees over others, as I have seen them return to the same tree until it was nearly stripped. When disturbed they always take to the trees, walking about in them." 


\section{FRANKLIN'S GROUSE.}

\section{Canachites franklini.}

Extremely similar to the foregoing, but with the tail black to the end, or bordered with white; its coverts white-tipped. The female has the tail feathers tipped with white and the upper tail coverts streaked with white, as also have the full-grown young of both sexes which have not yet assumed the plumage of the adult. It is slightly larger than the Canada grouse: length, over 15 inches; wing, $7^{\mathrm{T} / 2}$ inches; tail, 5 inches or over.

Franklin's grouse is found in southern Alaska, central British Columbia and west central Alberta, south to western Montana, central Idaho and northern Oregon east of the coast range. At many points in northwestern Montana, northern and central Idaho it is abundant. It is the bird commonly called "fool hen" in the western mountains, though this, after all, is a general term applied to any grouse or quail that has not yet learned that man is an enemy to be dreaded.

The differences in plumage between Franklin's grouse and the Canada grouse are so slight that they are not likely to be noticed by the average gunner, though at once obvious to the ornithologist. So far 
as is known, their habits are closely alike, though about the present species not very much has been written.

Unless they should greatly change in habits, neither the Canada grouse of the East nor the Franklin's grouse of the West is likely ever to offer much sport to the gunner. These little birds are so gentle and confiding that they hardly take the trouble to move out of the intruder's way; they will stand on the ground

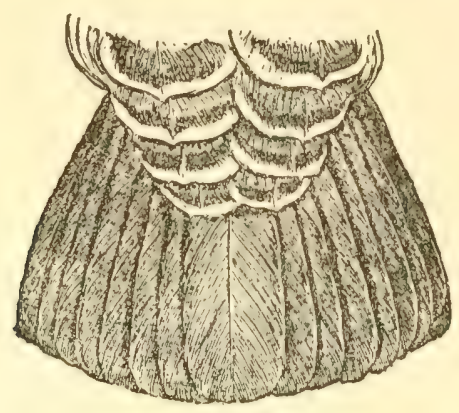

TAIL OF FRANKLIN'S GROUSE

or a limb to have a dozen shots fired at them, or may be pelted with stones and sticks without manifesting great alarm. I knew of one at which several rifle shots were fired, the last of which cut off one of the bird's feet. It staggered on its perch, and then, regaining its balance, stood there on one foot, apparently wondering what had happened. It is often possible to capture these birds by means of a noose tied to a pole six or eight feet long, by means of which the noose can be slipped over the head.

It used to be not unusual, and no doubt in many lo- 
calities still is so, for a brood of these birds to fly into a tree and sit there unalarmed until the heads of half or all of their number have been cut off by the rifle balls of some passing traveler. The flesh is excellent eating, and in places where fresh meat is not easily to be had, many of these birds are killed along the trails. On the other hand, it is to be remembered that the country in which they live is sparsely inhabited by man, and that those which he kills constitute only a very small fraction of the whole number in a district. On the other hand, it is difficult to comprehend how these birds escape their natural enemies, and heavy toll of them must be taken by lynx, fox and wolf.

With the destruction of the forests, which now threatens us, the numbers of both these forms of grouse must constantly diminish, but before the birds are too greatly reduced in numbers some means should be devised for their preservation.

Franklin's grouse is still more gentle and unsuspicious than the Canada grouse, its eastern cousin. One may frequently walk up to within fifteen or twenty feet of these birds as they sit on the ground or on the low limbs of trees without apparently being noticed by them. When they discover the approach of man they seem at first but little interested, but as one draws nearer, they are likely to stretch up their heads and look more carefully. If really alarmed or uneasy they stand very erect, holding the neck outstretched, and often raise the feathers on the sides of the neck just below the head. This habit is common to this species and to 
the dusky grouse, and is seen to a greater or less extent in other members of the family, as the ruffed, pinnated and sharp-tailed grouse.

Franklin's grouse is commonly found in the summer in timbered valleys, often close to the water, but sometimes also on timbered plateaus much higher in the mountains. I have not observed that it seems especially to prefer swampy lands, as the Canada grouse is supposed to, but rather a thickly timbered country, not far from water.

Even if alarmed and forced to take to wing, they do nothing more than fly up into the branches of the tree immediately above them, where they always either huddle down on a branch, as if to rest again, or, if seriously frightened, stand with head erect, stretching the neck out, first in one direction and then in another, until the cause of alarm has passed, or their suspicion has become allayed.

Contrary to what might be expected, the spruce partridge, found in west central Alaska, is not Franklin's grouse, but a form of the Canada grouse. 


\title{
RUFFED GROUSE-PARTRIDGE.
}

\author{
Bonasa umbellus. \\ Bonasa umbellus togata, \\ Bonasa umbellus umbelloides, \\ Bonasa umbellus sabini.
}

The ruffed grouse is peculiar to North America, and is found mainly in the Transition and Canadian life zones. Ornithologists recognize four geographical races in different sections of the continent. Of these four forms, the typical species (Bonasa umbellus) inhabits the eastern United States as far north as northern Massachusetts, thence westward to and beyond the Mississippi River; in southern Vermont, southern New York, through Ohio, Michigan, IVisconsin and southern Minnesota, touching the eastern portions of North and South Dakota, eastern Nebraska, eastern Kansas and Missouri, northern Arkansas, Tennessee, Kentucky, and in the Alleghanies to Georgia. The ruffed grouse of northern New England, northern New York, northern Michigan and eastern Oregon, known as $B$. umbellus togata, the Canada ruffed grouse, is found also northward to Nova Scotia, Manitoba, central Keewatin, southern Ungava and British Columbia. The gray ruffed grouse (Bonasa umbcllus umbclloides) occurs in the central Rocky Mountains, from Colorado, 
Utah and western South Dakota to Alaska, along the Yukon and Mackenzie rivers, throughout much of British North America, east as far as Manitoba. Another darker race (Bonasa umbellus sabini) inhabits the wooded country of the northwest coast region of southern Alaska, to Humboldt County, California.

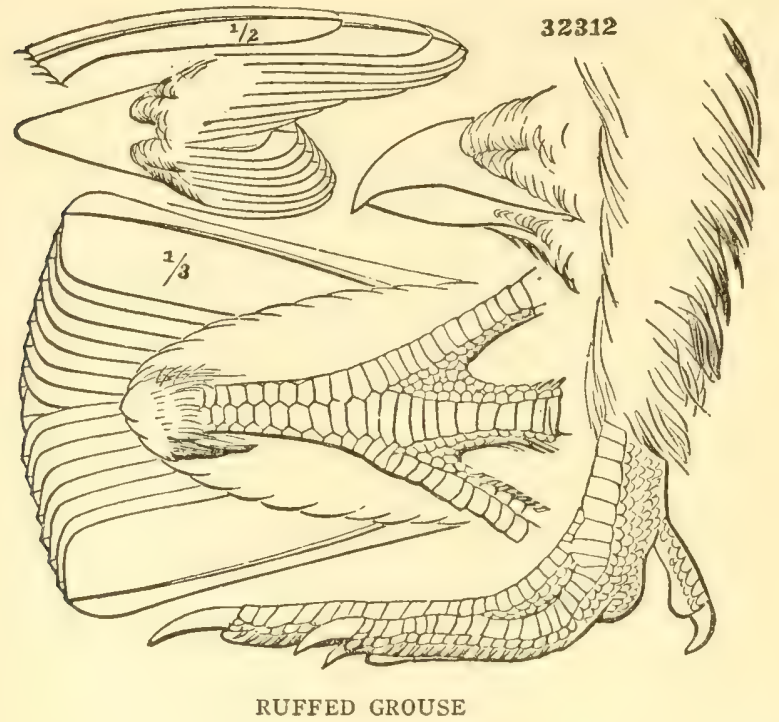

All these forms are very similar in appearance, and it is not unusual to find in one locality a bird which, in color, may closely resemble those of some far distant locality. The most that can be said for these races is that they average lighter or darker-as the case may be-than certain other relations, the center of whose abundance may be far distant. 
Bonasa umbellus is above, reddish brown or grayish brown, varied with black, brown and gray in different shades, the scapulars and wing coverts streaked with whitish or cream color, the rump and upper tail coverts with long streaks or spots of grayish or yellowish. Tail long and wide, gray or reddish, more or less banded with paler, each pale band bordered by a narrow, irregular blackish edge. A broad sub-terminal band of black or dark brown near the end, followed by a narrower terminal band of grayish. Feathers of the tufts on the side of the neck-the ruff-usually broadest at the ends, and black in color, sometimes with greenish reflections. Occasionally the ruff, instead of being black, is dark brown, or even pale chestnut. The throat is pale buff, sometimes dotted with darker. The lower parts are whitish or yellowish, barred with dull brown, broadest and darkest on the flanks. The lower tail coverts are white-tipped. The female is similar to the male, but smaller, and with the plumage slightly paler. At the same time the plumage often fails to give any suggestion of sex. There is a high-pointed crest on the head. The lower portion of the tarsus-that is, of the foot-is naked.

This is a general description of the ruffed grouse. The typical umbellus is described as mostly reddish above. The sub-species, B. umbellus unibelloides, is mostly gray, and has the tail always gray. It is regarded as the Rocky Mountain form.

B. umbellus togata, the Canada ruffed grouse, is 
mostly grayish, and the tail is usually gray, but sometimes tinged with reddish.

B. umbellus sabini is dark reddish, with little or no gray. This is the northwest coast form, found in the region of great precipitation, and by many is considered the most beautiful of the ruffed grouse.

The descriptions of these sub-species do not always give a very clear idea of the grouse of the regions the various forms are supposed to inhabit. The center of such a region, no doubt, will be occupied by birds of the typical form. On the border lines, however, where the sub-species tend to meet, individuals may sometimes be found that are typical of some taken thousands of miles away.

The length of the ruffed grouse varies from i6 to I9 inches. The wing measures from 7 to $7 \frac{1}{2}$ inches, and the tail from $5 \frac{\mathrm{I} / 2}{2}$ to 7 inches. The extent of wing varies from 22 to 25 inches, and the bird commonly weighs from 2 I or 22 up to about 30 ounces. Grouse are often reported to weigh $2 \frac{I}{4}$ or $2 \frac{I}{2}$ pounds; but it may be doubted if birds so heavy are ever found.

The ruffed grouse is the best known and most highly esteemed of the game birds of the North, and in Canada, New England, northern New York, Pennsylvania, Michigan and Wisconsin it is now the most important of the upland birds.

In the South the bird is called "pheasant," and in the North, especially in the Northeast, "partridge"both misnomers, since it is neither. In parts of Canada 
it is called "birch partridge," in contradistinction to the Canada grouse, called "spruce partridge."

The grouse spend the winter in thick, deep swamps, or else on steep hillsides in sections where evergreens grow, which give protection from the snow, in dense runs, and white birch and other thickets.

Life is easy for the birds, which wander about over their limited range, scratching, when the snow is not too deep, for the fruit of the skunk cabbage, for the fruit and leaves of wintergreen and partridge berry and arbutus, for hibernating insects, for nuts overlooked in autumn by themselves and the squirrels; or, if the ground is deeply snow-covered and ice-bound, taking to the tree-tops, where they glean a plenteous harvest of buds, and usually come out in spring strong and well nourished. At Lake George, New York, the grouse feed extensively on the buds of ironwood, poplar, birch and apple, from late October to early April, irrespective of the snowfall. An hour or two before sunset they fly to the trees and gorge on the buds and catkins.

In New England and the Middle States the mating time comes in early April, after the weather has grown warm and the grass and flowers have begun to spring. By this time the grouse has begun to sound his drumming call. In a country where grouse are plenty you may hear the sound from a hundred hills, but you will find it a difficult matter to trace it to its source, and when you approach the place from which you thought it came, you will find it is no longer heard there, and when it next reaches your ear it seems a long way off. 
In the Rocky Mountains, in September, a few years ago, I saw a grouse cross the trail along which I was walking and disappear in the bushes to the left. The clump of bushes was a small one, not more than twenty yards across. I watched the bird while it was walking perhaps ten yards, and then went on, but had hardly come to where the bird had crossed the path when I heard it drum. The sound was not loud and gave the impression of being quite distant. I stood still for a moment, trying to see the bird, but without success, and after a little while the drumming began again, still sounding as distant as before. I then very quietly made my way into the bushes, advancing six or eight yards toward the point where I had last seen the grouse, but the drumming was not resumed, and after a few moments I withdrew, but had hardly reached the trail when I again heard the sound. A second excursion. into the bushes was no more successful than the first had been, but somewhat later, on my return, hearing the drumming, I again went into the bushes, and just beyond where I had seen the grouse disappear I saw it walk away among the brush. This is mentioned only to indicate how very faint the sound of the drumming may be, although it is quite close at hand.

Few subjects have been more discussed by American naturalists and sportsmen than this same drumming, a sound so familiar to outdoor men as hardly to need description. It is commonly thought to be a mating call, though by no means sounded only at the pairing season in spring; for the roll of the drumming, sound- 


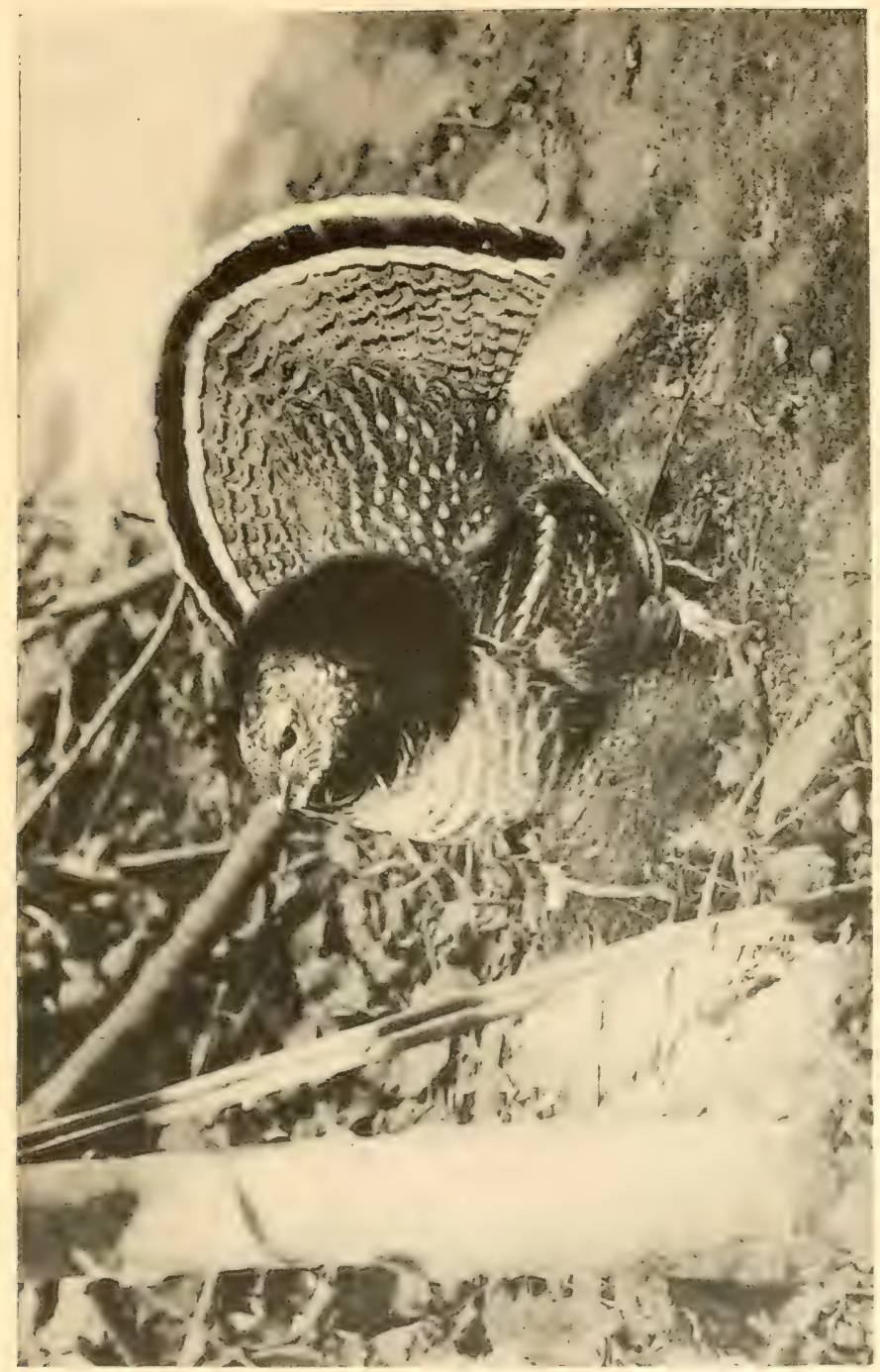

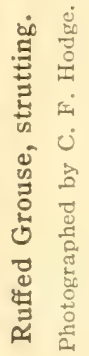



ing like far-off thunder, is often heard in late summer and autumn. It is possible that this autumnal drumming is made by the young males, just as sometimes in autumn a young male songbird may be heard to practice in low tones the lay which it will utter during the mating season of the following spring. A great variety of explanations have been given as to the method by which the drumming is produced. It is made by the wings, and the observations of ornithologists have established the fact that the sound is caused by the outspread wings of the bird rapidly beating the air without striking the bird's body or any other object. Photographs taken by Professor Hodge show the wings beating in front of the breast as the bird sits upright during the act. The belief that the resonance of the sound is caused in part because, while drumming, the bird stands on a hollow log, was long ago abandoned. One of the best descriptions of the process of drumming is that given by Mr. Manly Hardy, of Brewer, Maine, who says: "The cock grouse usually selects a mossy log near some open hedge, clearing, or woods road, and partly screened by bushes, where he can see and not be seen. When about to drum he erects his neck feathers, spreads his tail, and with drooping wings steps with a jerky motion along a log for some distance each way from his drumming place, walking back and forth several times and looking sharply in every direction. Then standing crosswise, he stretches himself to his fullest height and delivers the blows with his wings fully upon his sides, his wings being several inches clear 
from the log. After drumming he settles quietly down into a sitting posture and remains silently listening for five or ten minutes, when, if no cause for alarm is discovered, he repeats the process."

Mr. Ernest E. Thompson, in his "Birds of Manitoba," describes the drumming as he saw it. It is said that if, during the drumming, another male grouse makes its appearance near the drumming place, the birds fight with much spirit. An account of such a battle is given by a correspondent of Forest and Stream, who writes from Schenectady, New York, and signs himself "Dorp." He says, in substance:

"I was walking along a country road, about the first of June, when I heard from the depths of an adjacent wood an unusual rustling sound for which I could not account. The sound stopped, began again, again stopped, and was repeated at intervals of a minute or two. Not knowing what caused the sound, I crossed the fence and cautiously approached the place. After I had gone about fifty yards, screening myself as much as possible behind trees, I came up to within twenty yards of a large dead log, upon which stood two ruffed grouse in battle array. They stood something like six feet from each other, with the black feathers around their necks raised till they almost pointed toward their heads, which were lowered, and which they were shaking at each other in defiance. In a few moments they gradually approached each other, and when about two feet apart they rushed together, the momentum and their wings carrying them into the air about a foot 
above the log. While there they struck repeated blows and then fell back to the log, where a short tussle took place, when they separated and moved back to a distance of about six feet from one another.

"After an interval they advanced toward each other again and repeated the same performance as before. The desperate battle went on by 'rounds' till several were fought. How long the fight had been going on before I came upon the scene I had no means of knowing, but after they had come together several times in my presence, the bird that seemed the smaller moved backward, still presenting a defiant attitude, with his head lowered, till he came to the end of the log, when he jumped off and disappeared.

"Upon this the victor raised himself and stretched up until he nearly stood on his toes, expanding his wings at the same time. It looked for a moment as if he would crow. Then settling himself back, he brought his wings down against his breast with a sound like that produced by forcibly striking a bass drum. Again he raised his wings and repeated the sound. Still continuing to raise and lower his wings more and more rapidly, the sound finally rolled away in one continuous murmur and was still.' The sound was indescribable. As soon as he had drummed he jumped off the $\log$ and disappeared. Wishing to know if the female, the probable cause of the conflict, was near by, I adranced rapidly and started her, together with the victor, and a short distance away the defeated bird."

An interesting account of a case of drumming in 
the autumn, with its possible cause, is given by this same correspondent of Forest and Stream, who says:

"On one occasion, while out shooting in Clifton Park, I fired at a grouse, which fell to the ground and fluttered over it for some distance, but before I could reach him rose again and, flying high, disappeared over the tops of the trees in the woods. Pursuing, I looked the ground well over, but was unable to find him. It so happened that two or three days after this occurrence I was again on the same ground, and remembering the wounded grouse, went in search of him. I had not gone far when I heard a grouse drum, and moving cautiously I finally got behind an old mosscovered stone wall that ran through the woods. I had often heard grouse drum, but I had never seen one perform the act, and I was very desirous to do so. After a while he drummed again, and I moved along the fence, nearer, having by this time got his bearings. Upon looking over the wall I saw the bird standing on what I supposed to be a stone about five or six inches in height. After he had drummed he pecked at the supposed stone and then bobbed his head and tail up alternately, the latter being spread out. Then he jumped off the object and walked in a wide circle around it, after the manner of the turkey cock, with wings lowered. After an interval he got on the stone again and drummed and performed as before. About this time something alarmed the drummer and he disappeared into the covert.

"Upon going to the spot where he had drummed I 


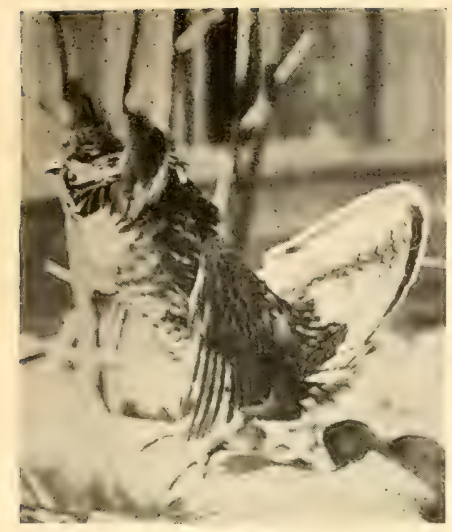

First position

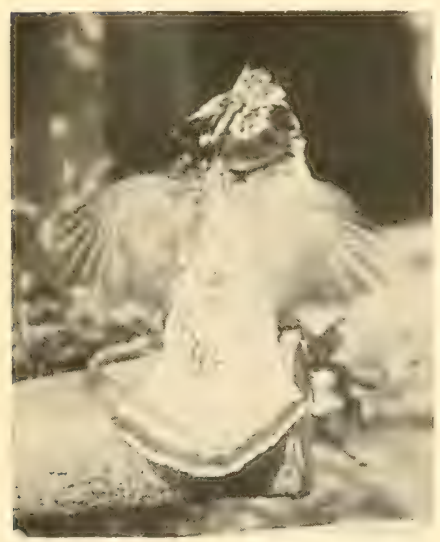

Faster

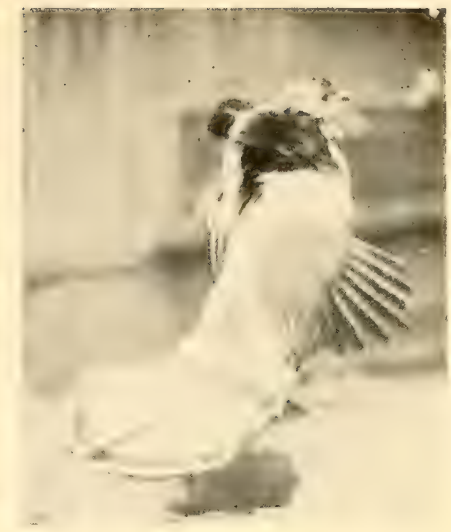

First wingstrokes

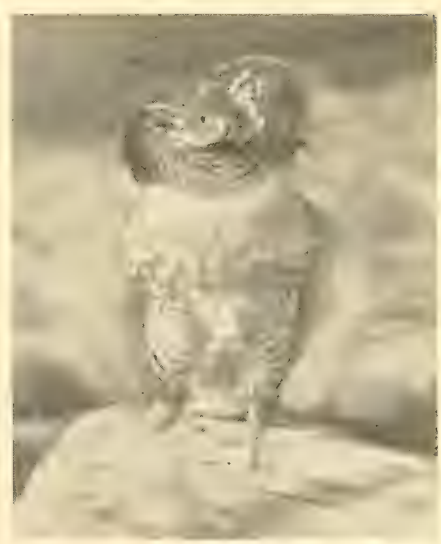

The roll

The drumming Ruffed Grouse.

Photographed by C. F. Hodge. 

was astonished to find what I supposed a stone to be a dead male grouse. Upon it the drummer had stood and drummed, and about it he had paraded as described. The dead bird had one shot only, through his head. It was the same I had shot a couple of days before, which had flown there and fallen dead.

"I have read that the drumming of the ruffed grouse is a demonstration of love and courtship, but from this incident I conclude that it is also either one of rivalry and triumph, or sounding a knell or requiem of a departed mate or friend."

With this should be compared Audubon's account of the actions of a wild turkey cock after a fight in which he has killed his rival.

This same correspondent of Forest and Stream, an observant man, has expressed the view that the grouse drums to announce the approach of day at dawn, to announce any approaching unusual atmospherical change during the night or day, to make his whereabouts known to the female, to celebrate her coming, to announce a triumph over a rival, to sound a requiem over a dead mate or friend, to amuse himself. Most of these motives are precisely those which are supposed to actuate the domestic cock in his crowing, or in the flapping of his wings which commonly accompanies the crowing. It is certainly true that the grouse drums at night as well as by day, and that he frequently drums just before daylight and often just before "a change of weather."

Although so excellent an observer as Captain Ben- 
dire thinks that the drumming cannot be considered a love note because, as he says, "It may be heard almost every month in the year and sometimes in the night as well as in the day time," I am disposed to think that it is really in part a mating call. Other grouse perform certain operations usually thought to be connected with the mating time in autumn as well as in spring. The sharp-tailed grouse holds its dances in autumn, and I have been told that the dusky grouse hoots in the autumn as well as in spring, though by no means so vigorously. Certainly we may believe that at the proper season of the year it possesses an attraction for the female, and S. T. Hammond, in his capital book, "My Friend the Partridge," gives some testimony to this effect.

The nest of the ruffed grouse is built almost anywhere, yet perhaps most often on a hillside more or less steep, overlooking a swamp or a piece of woods. I have found nests among thick cedars on a hillside, or perfectly open and exposed, at the foot of a cedar tree in a mowing lot close to a fence, and again between two cedars in an open piece of cedar wood, where there was no apparent cover whatever. The eggs are laid usually in April or early May, and by the middle of that month the clutch of twelve to seventeen is usually completed. The eggs are cream color or buffy, rarely spotted with brown at the larger end. If the female is startled from her nest she leaves it with a roar of wings, whose rapid beats often spread over the precious eggs the dry leaves by which the nest is likely to be surrounded. On a num- 


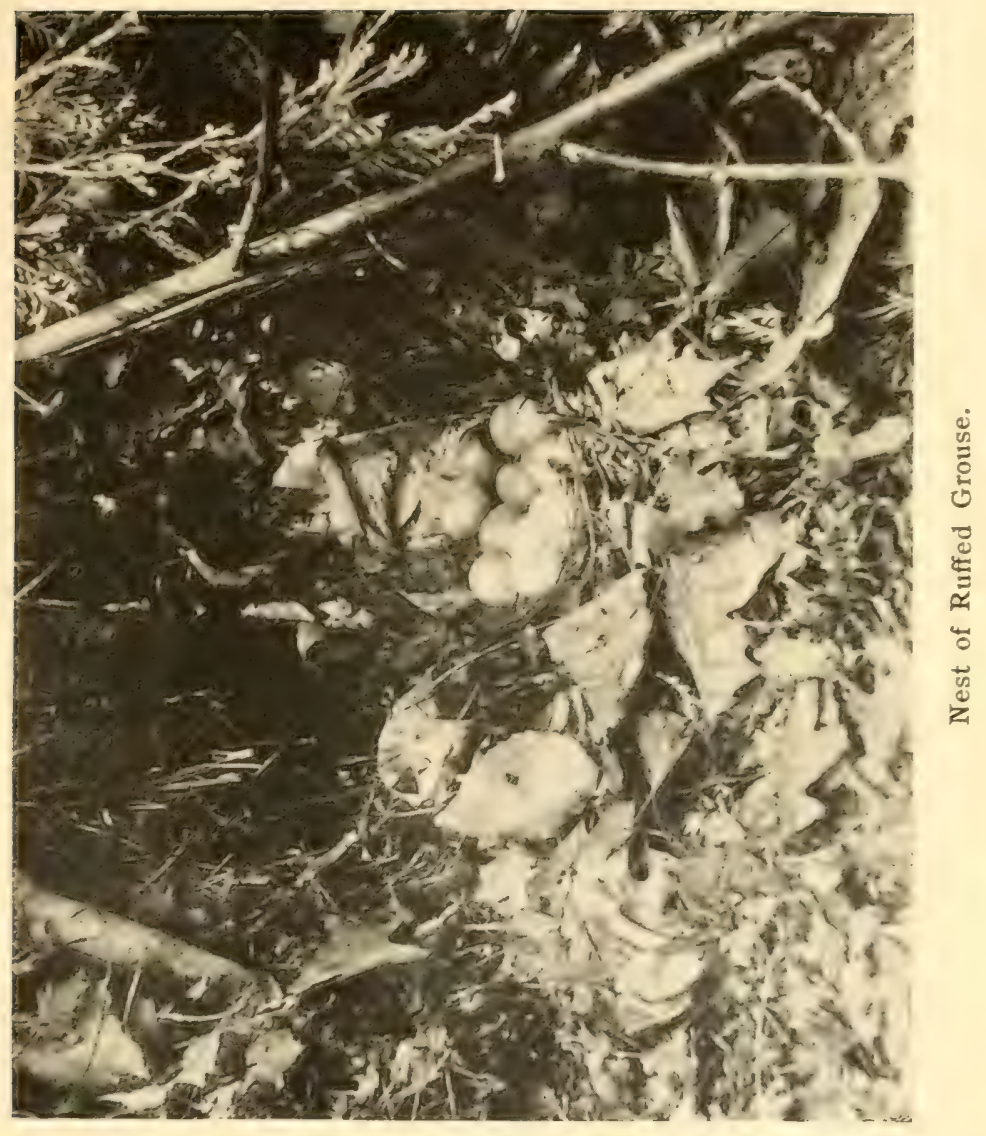



ber of occasions I have seen the eggs almost wholly hidden by this simple means.

Most sportsmen know how very difficult it is to see game birds when they are not in motion. The bird's feathers harmonize so admirably with its surroundings-whether these be the leaf-strewn ground of October, the bare branches of December, or the yellowing grass and weed stems of July-that it is often almost impossible to detect the bird, even though one knows precisely where it is. I recall an occasion when, happening to cross a fence which separated a road from a mowing lot, I almost stepped on a female grouse as I sprang to the ground. She was sitting on a nest with thirteen eggs, at the foot of a large cedar. Often after that I used to go down to the lot and slowly approach the place to look at the bird as she sat on her eggs. She soon became so accustomed to me that she manifested no alarm, and I could approach quite close to her. It always took me some little time to see the bird, though she sat in plain sight, with only half a dozen slender grass stems between her head and me. After looking for some time at the spot where I knew she sat, the shape of her head, her markings, and above all her bright eye, would gradually grow out of the confusion of the grass stems in front of her and the cedar bark beyond, and I could see the whole bird plainly. Yet if I turned my eyes away it again took a little time to find and recognize her.

The eggs hatch from the first to the middle of June, and the young often number as many as a dozen or 
fifteen. They leave the nest at once and nimbly follow the careful mother, as her chickens follow a domestic hen. She leads them quietly through the woods, teaching them the while how to live their lives and how to keep themselves safe from their enemies. At her call of alarm each chick sinks down on the ground and disappears, looking like a leaf, a bit of stick or a pebble. No one can recognize them as living things, and their only danger is that some clumsy person may step on one of them. Meantime the mother, with feathers erect and trailing wings, is limping in front of the intruder, falling down, pushing herself along on her breast, panting as if in the very agony of death, often "growling" or "whining" in the effort to lure the enemy away from the brood. Usually she succeeds. No dog, and few boys and men, can resist the temptation to catch a partridge. The pursuer runs forward and almost grasps her, but his approach seems to give her a little strength and she flutters feebly forward. A few steps more and she will be his; but still she evades him, and presently, after having gone thirty or forty yards, she rises on strong wing and, swift as a bullet, darts off among the tree trunks. If the pursuer returns to the place where he first saw her, sits down and remains there quiet, after a time he will see her return on foot, call together her little brood and start off again on her travels.

In Captain Bendire's admirable work, so often cited, Manly Hardy, after describing the actions of the mother bird, says : 
"I have once seen the old cock with the brood, and on this occasion he gallantly defended the rear until the rest made good their escape. He stood with wings raised and tail spread, ready to fight the intruder. I have seen the young fly into a tree when still in the yellow down, and when not larger than a pine grosbeak they will fly long distances, giving the alarm note of 'quit, quit,' just like an old bird. The young a few days old are shyer than the wariest adult. The noise made by the ruffed grouse in flying 'is made on purpose' to alarm others in the vicinity; they can fly as quietly as any bird if they choose.

"The males never congregate during the breeding season or after, and I never but once saw two adult males within one-fourth of a mile of each other between April and September. I consider that the drumming is not a call to the females, as they drum nearly or quite as much in the fall as in the spring, and I have heard them drumming every month in the year. I have never seen the least evidence that the ruffed grouse is polygamous."

With this last statement I quite agree. I know of no evidence to justify the common assumption that this grouse is polygamous.

When the young birds are two or three weeks old their wing feathers have grown enough to enable them to fly, and sometimes, if suddenly surprised, some of them may leave the ground and fly up into low branches, where they stand motionless with their necks 
stretched upward and may be so closely approached that one may almost take them in the hand.

By the middle of August the young are almost fully grown, and as cool weather approaches they begin to separate, no longer keeping in a close flock, but wandering off by twos, threes and fours. As the weather grows colder they become still more solitary in their ways, although up to midwinter two or three may often be found together.

This has been my experience; but other observers, whose opinions are entitled to the greatest respect, believe that the broods keep together until midwinter, unless broken up and scattered by the gunners. But if this is true, how do the birds get together after the "crazy season"?

Dr. A. K. Fisher expresses the opinion that comparatively few grouse become "crazy" birds. He is inclined to believe that the "crazy" birds are lost birds -i.e., individuals that for some cause or other have been driven from their homes, and do not know how to return.

It is during late September and October that the grouse for a short time wander about in a most eccentric manner and indulge in such unusual performances that this is sometimes called their "crazy season." Having separated, they seem to be searching for new homes or perhaps for winter quarters, and wander about in seemingly aimless fashion, so that they are often found in most unusual places. Such are vacant buildings, village streets, the lawn of a country place, 
or even within a covered country bridge. At this time, too, they often fly against houses or fences, or through windows, opened or closed, and in this way many birds are killed. I have personal knowledge of three birds flying against houses, one against a fence and two through windows, opened or closed, on a single farm in Connecticut.

A correspondent of Forest and Stream says:

"Once while walking along the street I saw a grouse dusting in the roadway. At first I supposed it was a hen, but as I approached, it rose, flew straight down the street and in at the opening of the large covered bridge that spanned the Molnawk. The bird lit on a beam near the roof. Getting up to the beam I took the bird off. He remained perfectly motionless, as is their habit when approached by man. This grouse when he rose in the roadway made comparatively little noise. . .."

The same writer says: "I recollect an incident that occurred in our city where a grouse flew into a small barn and perched on a beam. The owner of the premises having invited a gentleman into the barn on some business, the guest said to the owner: 'I see you keep poultry.' 'No,' said the owner, 'I keep no poultry, but my neighbors do, and I wish they would come and take that pullet away. She has been here now three or four days and I am tired of feeding her.' The visitor looked a little more sharply and said: 'That is not a pullet; that is a partridge'; and so it was, to the great surprise of the other."

The food of the ruffed grouse is very varied. In 
summer-and especially for the young birds-insects, notably grasshoppers and crickets, make up a portion of its diet. It is fond of berries of all sorts, and blackberry patches and wild grape vines are often visited by it when the fruit is ripe. Indeed, from midsummer until early winter there are always berries for them to feed on. In autumn also they feed on fallen apples, and wild apple trees in the midst of woods are a favorite resort for them morning and evening. They eat some grass and the leaves of many plants. They feed on the fruit of the skunk cabbage (Symplocarpus); early in the winter tearing away the pithy covering that holds the seeds and picking them out from their spongy bed, or later gathering them from the ground.

Most of all they like nuts, such as chestnuts, acorns and beechnuts. I have taken from the crops of grouse two or three pignuts, a double handful of chestnuts and as many beechnuts as I could hold in one hand. There is a record of a small snake having been taken from a grouse's crop.

The Biological Survey has shown that over Io per cent. of the food of the ruffed grouse is animal and 89 per cent. vegetable matter. The vegetable food is seeds, more than I I per cent.; fruit, more than 28 per cent. ; leaves and buds, more than 48 per cent. Most of the insects eaten are injurious; either those that prey upon the growing crop or borers destructive to the forest. Every ruffed grouse that is killed, if he had lived out his time would have destroyed a great mul- 
titucle of harmful insects and so would have done good service to the farmer.

Although grain has not been found in the crops of any of these grouse, there is no doubt that it is eaten when obtainable. The birds are often seen scratching in the roads, presumably for oats dropped by the horses, and I have vivid recollection of a partridge which one winter could be started two or three times a day at the head of a small pond where corn had been scattered along the edge of the water to attract the black ducks. This grouse frequented the place all through the winter to feed on the scattered corn.

In autumn, winter or spring it resorts to orchards to feed on the buds of the trees, but it probably does no harm in this way. Buds and the leaves of poplar, birch, ironwood and willow form a large portion of the food of the grouse. It is said that the buds of the black birch are sometimes eaten so largely that they impart a taste to the bird's flesh. In Alaska, E. W. Nelson found the grouse feeding on spruce buds and declared that the flesh had become bitter from this diet. There was long a belief that the flesh of the ruffed grouse was sometimes poisonous because it ate the buds of the laurel. The statement was made by Alexander Wilson, and cases are quoted by Mr. Judd to show that there is a foundation for the belief. On the other hand, grouse which had fed on laurel have been eaten without any resulting harm. It is quite possible that where injury has resulted, it came from leaving the bird undrawn for a long time after death, when the 
poison from crop and intestines spread itself through the flesh. Grass, flowers and especially red clover are often found in the crop of the ruffed grouse, and many other plants in small quantities. A grouse shot at Lake George had its crop distended with the leaves of the spearmint.

Few birds are more local in their habits than the ruffed grouse, and one who is familiar with their ways can usually visit the same spot in the woods at the same time of the day and be quite sure of starting a bird. A brood of birds started and scattered in all directions will be found a few hours later within a few hundred yards of the place from which they flew. I believe that a circle with a diameter of half a mile will cover the range of a group of ruffed grouse during the summer or during the winter. In spring and autumn, of course, there are marked changes of location, the causes of which are not well understood. We merely know that these changes take place, and that they shift their ground with the seasons, usually being found in different places in summer, autumn and winter. The bird has a certain place for resting-basking in the sun or wallowing in the dust-another for feeding and another for drinking. Very often it passes between these different places on foot, but not infrequently it flies. It is perhaps during their flights in new and unfamiliar localities that they dash themselves against houses or other obstacles. Occasionally they are killed by flying against telegraph wires.

When a grouse rises, it is likely to fly swiftly and 
straight at a distance of not more than from three to thirty feet above the ground. As it approaches the place where it wishes to alight it sets its wings and sails straight for the place and there alights on the ground. I do not think that it ever turns up in the air as a quail does, but on the other hand I have never seen a bird actually alight. In winter I have, however, seen where they had come to the ground after a short flight, and the impression of the bird's breast in the snow two or three inches deep. The breast evidently came down very close to the ground, sweeping away the snow, and the grouse came to its feet at once.

I have seen a bird fly from the top of a high hill to a piece of woods much lower down. It came straight until it was almost over the woods, and then, making a wide half circle, swiftly lowered and alighted among the dry leaves not more than twenty steps from me.

The various methods by which the grouse avoid observation are little known and are seldom observed by those who are only occasionally in the woods and who, when there, are possessed with the idea that they must kill as many birds as possible in the time at their disposal. The ones more likely to see such things are the men who spend much time in the woods and have the leisure to sit down and observe, watching the ways of the wild creatures, which, after a time believing that the intruder has gone away, emerge from their hiding places and resume their usual pursuits. But if the ob- 
server makes a movement and the bird sees him, it will stop for a moment, look carefully, and then, turning, will seem to melt out of sight. It is most difficult to tell when it disappears. Under such circumstances a bird will sometimes fly, but more often will run for two or three yards and disappear, and then springing from the ground at a greater distance will fly off low, not being seen after it takes to wing.

Rarely one may see a frightened grouse on the ground and may get up close to it, but if he does this and wishes to observe the bird, let him avoid looking directly at it. If it catches the observer's eye, it is almost sure to fly, and when it flies the very fact that you are so close to it may make the shot a difficult one. On one occasion many years ago, after shooting two or three times at a grouse, the dog pointed it at the foot of a great oak tree. The other dog backed, and my two brothers and myself, realizing where the bird must be, surrounded the foot of the tree. Presently we saw it crouched on the ground between two roots, looked squarely at it and talked about it. That grouse must have had an unhappy time, for it feared to fly. For some little time we looked and talked of it, and then, fearing that the pointing dog might try to seize the bird, which was almost under his nose, one of us stepped forward and grasped his collar. As this was done, the grouse took wing, twisted around the root of the tree, passing within two feet of one of my brothers, dodged away and up and over a little rise of 


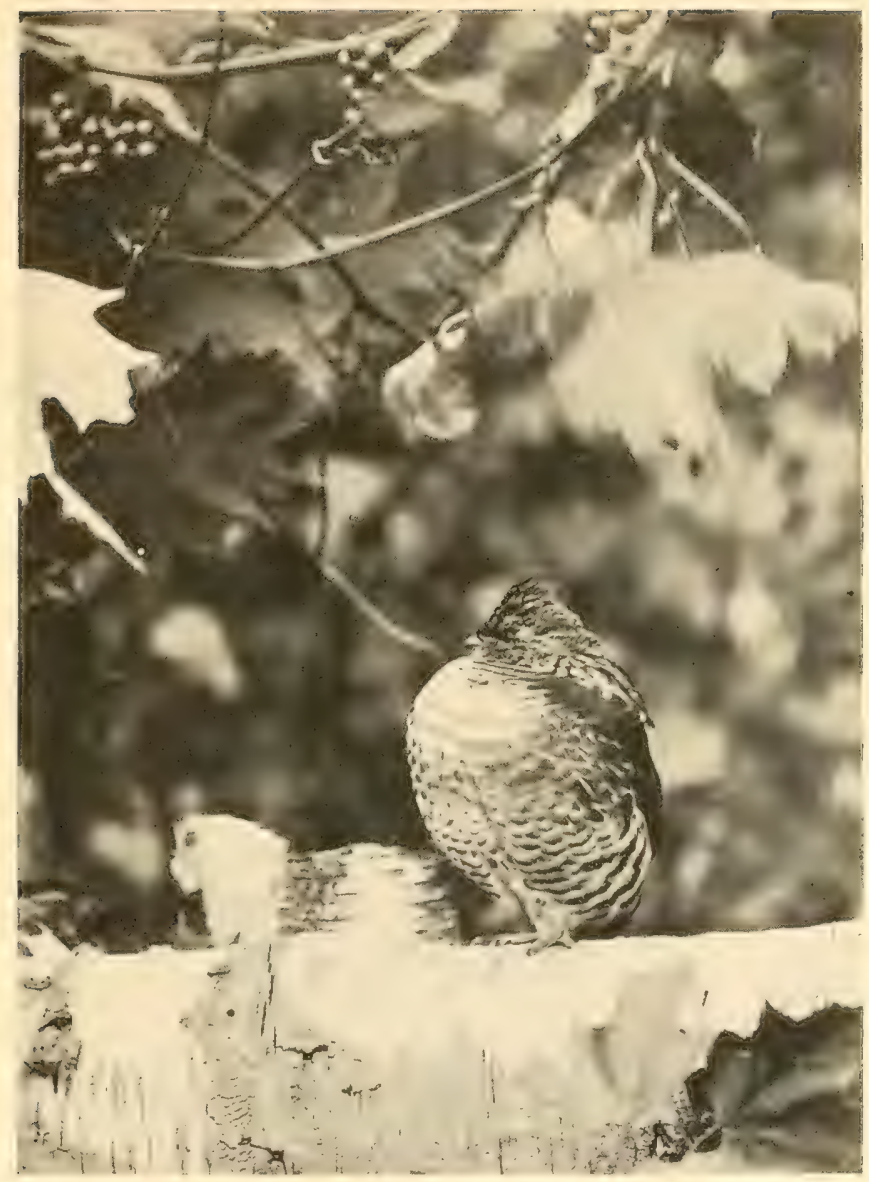

Daydreaming.

Photographed by C. F. Hodge. 

ground twenty yards from us, escaping untouched, notwithstanding the fact that three shots were fired at it.

The grouse sometimes takes refuge in the snow in cold weather, and is credited with diving into drifts at nightfall and passing the night there. A friend walking through the deep snow along a little swale, through which passed a brook, saw sticking up out of the snow what he supposed was an odd-looking stick. He declared to himself that it looked just like a partridge's head, and when he had come within a few feet of the place a bird rose out of the snow like a whirlwind and flew away to a near-by swamp.

No doubt these birds often inspect the gunner when he is little aware of their observation. Dorp tells of a case of that kind in the following words:

"I turned to resume my walk, and as I did so I cast my eyes upward, and there on a plateau covered with moss and projecting nearly over me stood a ruffed grouse looking intently down upon me. He was twelve feet from me, as I afterward measured it. He was partly turned sideways, with the neck stretched and head bent down, and made a beautiful picture with background of evergreen.

"He remained motionless, as I did also, for about a half minute, when he slowly turned and was quickly lost to sight. This was the closest I remember ever to have been to this wild bird in his native state when seen. I have been closer, but then I did not know it until he flew.

"This bird had heard me walking and his curiosity 
had prompted him to come to the edge and look down to discover the cause of the noise. Perceiving that my back was toward him he knew that I could not see him and so remained. Perhaps he had not seen enough of me to satisfy him, and when I turned around he knew I could not reach him. He had probably never been shot at and knew nothing of the power of the gun which I held in my hand, or of man's ability to harm at a distance."

In a country where it is much pursued by man or dog, the ruffed grouse, if unexpectedly approached closely, is likely to walk or run away rather than to fly. A good grouse dog follows the trail of the bird slowly and not much faster than the bird itself can run. Those of us who have possessed good grouse dogs, which are always scarce enough, have often seen them leave the trail, make a wide circle and come up on the other side of the bird to head it off and stop it. Unless something like this is done, the bird may readily enough be followed to the edge of the cover, where it will presumably take wing and disappear. If a dog is alone-especially if it be a dog of red or yellow color, suggesting a fox-the bird is likely merely to hop up on a limb well out of reach and remain there looking down at the enemy; but if a man follows the dog, the bird, if he gets into a tree, is likely to stand close to the tree trunk and remain absolutely motionless.

Ruffed grouse are subject to more or less unexplained periods of scarcity. During one season the woods will contain their usual number of the birds, and 
the following year very few may be found. After that it may take some years for the birds to recover themselves and again to become reasonably abundant. Whenever such a period of scarcity occurs, sportsmen very naturally endeavor to assign reasons for the reduced numbers of the birds.

Among the causes suggested are these: that they have been swept away by an epidemic disease, that they have been destroyed by insect enemies, that they have been killed by hawks, owls and foxes, that the breeding season has been unfavorable, that the winter's snow and cold have killed them, while many men believe that over-shooting furnishes the best reason of all. None of these explanations appear to fit all cases. The birds may succumb to disease, but there appears to be no evidence that they do so. The young chicks in traveling through the woods and swamps undoubtedly occasionally pick up wood ticks which suck their blood, and occasionally a young and weakly bird may perish from this cause. Those who attribute the scarcity of grouse at any time to hard winters-to their being covered up and frozen in under the snow-cannot know much about grouse nature. The bird is found far up in the north, where it is exposed to weather far more rigorous than it can ever experience in temperate climes, and if it had been so tender as to be killed by the winter, it would long ago have been exterminated in the mountains of Alaska, along the Mackenzie River and southern Ungava. It seems more probable that over-shooting must have much to do with these disappearances 
of the grouse, not directly, perhaps, but because by constant attacks the breeding stock is kept down so low that when conditions arise even slightly unfavorable to the species, and a few birds are swept away, the breeding stock is so reduced that not enough birds are reared the next season to replenish the covers.

The widest differences of opinion about this matter exist between sportsmen and naturalists of experience. So good a field naturalist as Nap. A. Comeau, in his recent book, entitled "Life and Sport on the North Shore," says of the ruffed grouse:

"In some years they are abundant for a time and then disappear. I have noticed that heavy sleet in winter will sometimes drive them away from certain tracts of country. Since I905 they have been pretty scarce all over the country (the north shore of the Gulf of St. Lawrence). I think this must be due to some kind of contagious disease, something similar, probably, to the 'grouse disease' of Scotland. There is no other way of explaining their scarcity over such an immense extent of territory. Where the country has opened up, and there are only patches of wood here and there, it would be reasonable to suppose that they might have been exterminated by over-shooting and snaring; but where there are thousands of miles of forests, and not one in a hundred shot over, it cannot be put down to excessive shooting. As to natural enemies, they do not seem to have been any more numerous here than elsewhere. Last year ( I908) I was over six weeks in the woods with two of my boys, and we only saw six. 


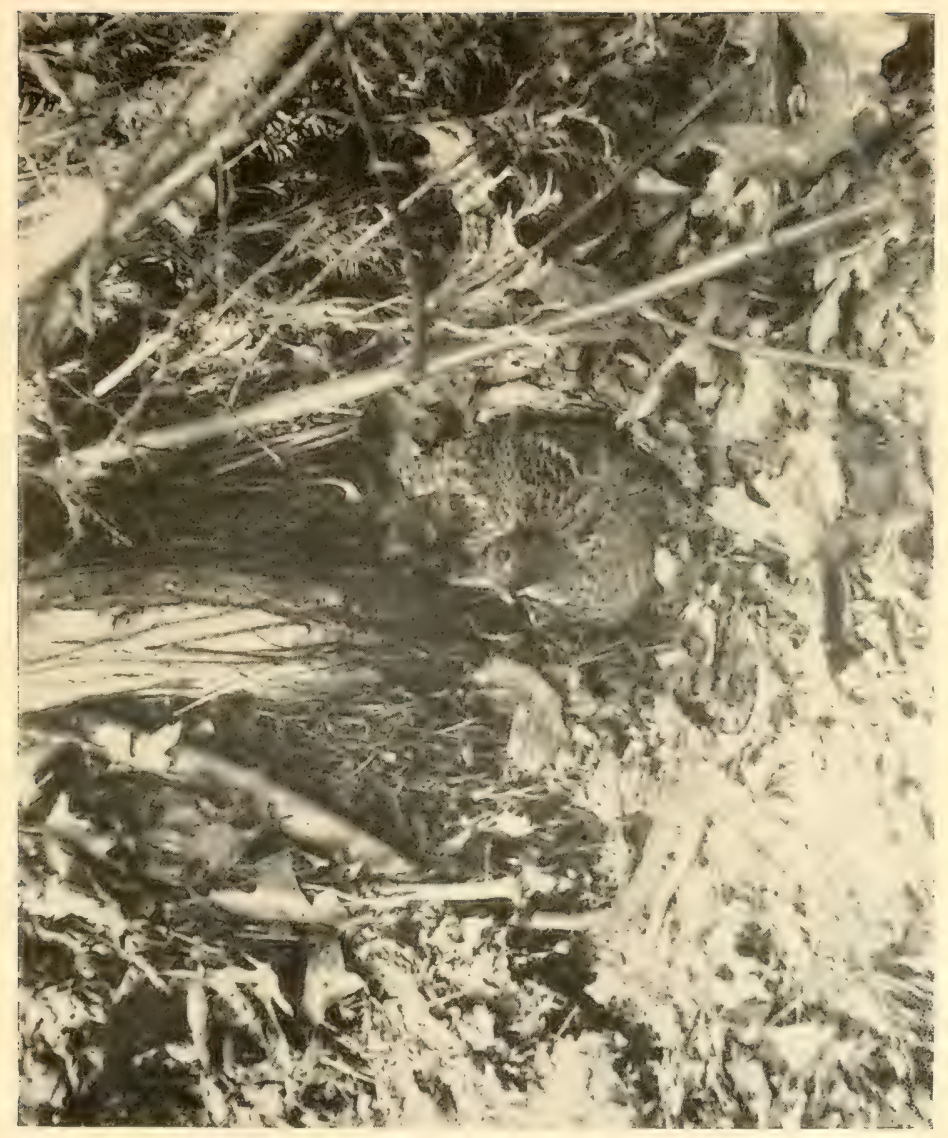



From various points throughout the country, both inland and along the coast, I received the same reportsno grouse."

Though constantly pursued by man during the open season and exposed to the attacks of a multitude of natural enemies, the ruffed grouse in many of our covers seems still almost to hold its own. There are seasons of abundance, when the birds are more numerous than usual, and others of scarcity, when sportsmen fear that they are about to disappear forever from particular localities; but they continue to exist, and will long exist over much of the wooded country of the Eastern United States. The cutting off of the forests constitutes the gravest danger to which they are exposed. Where this is done the birds disappear, but, even after the heavy timber has been cut off, a period of ten or twelve years often results in the reforestation of the tract, at first only with underbrush and saplings, but later with larger trees. Then the ruffed grouse tend to come back again.

For the ruffed grouse is a dweller in thickets. It seldom frequents the open land, except that it may venture out a little way from the edge of swamp or forest to pick up the grain in a cultivated field, or to eat the blackberries, huckleberries or wild grapes which ripen in some opening at the edge of the woods. For the most part, however, it is found in cover, sometimes quite open, among tall tree trunks of great size, or again in the most tangled swamp, among thickets of alder, blackberry, catbrier and grape vines. Wherever 
found-in a country that has been much gunned-it is well able to take care of itself. By much training it has acquired a great variety of tricks and stratagems which it practices to the utter discomfiture of many gunners. It may rise far ahead of the dog and out of shot and fly straight up a mountainside out of sight, so that it is impossible to mark it down; or if for some good reason of its own it continues to lie, it will very likely let man and dog pass it, and then when the man is tangled up in difficult brush and is trying to push his way ahead, the partridge with thunderous roar will rise behind him and disappear before he can free himself from his fetters and bring the gun to his shoulder. Very commonly the partridge runs rapidly ahead of the dog, sometimes in a straightaway course, apparently to make sure that it will be well out of gunshot before it rises, or, again, it may run straight away, and then, bending off to right or left, may come around nearly to its trail again so that its pursuers will pass it. This is the precise trick played by the moose and sometimes by deer and bear when the conditions are favorable for tracking them. A favorite device is to rise behind a tree trunk, a clump of brush, a great rock or even a stone wall, and to keep this barrier between itself and the gunner until safely out of range.

The flight of the grouse is very swift, and though when well under way usually flying straight, yet often it rises on a curve, so that one may easily shoot behind it. Although often rising from the ground with a thunderous roar of wings, which may upset the nerves 
of its pursuer, the grouse does not always do this. Frequently it takes wing as quietly as the smallest bird, so that unless the shooter happens to be looking in the bird's direction he may not be aware that it has flown. Sometimes, too, it will merely hop up into a tree and remain there, standing close to the trunk or to some branch, stiff, straight and motionless, and looking like a stub of wood. An old partridge may be counted on to do some unexpected thing. It deals in surprises. Its grace and beauty and the readiness with which it adapts itself to changing conditions, as well as the difficult places that it inhabits and the charm of its surroundings, unite to command the gunner's admiration.

Although where constantly shot at it practices a variety of such stratagems, yet in regions seldom penetrated by man and where it has not been pursued, it is absolutely gentle and unafraid, and if startled from the ground flies no farther than to a low branch of a tree where it may sit with outstretched neck and erect crest while half a dozen shots are fired at it from pistol or rifle. If, however, a ball should strike the branch on which it is resting, or if a twig cut from above it drops down and touches the bird, it darts away with the swift flight with which we are all so familiar. If in a park or in private grounds the grouse are left undisturbed, they may often be seen walking about and feeding, paying little attention to men who may pass near them, recognizing that no danger is to be apprehended from them. 


\section{WILLOW PTARMIGAN.}

Lagopus lagopus.

Lagopus lagopus alleni.

Lagopus lagopus alexandrce.

In summer the male has the head and neck chestnut, often becoming darker below. On the neck and chest this is often barred and flecked with black, as it is also on the flanks and generally on the under parts. The belly is more or less slate color. The quills and outer wing coverts are white and the rest of the upper parts irregularly barred with tawny, brown and black. Many of the feathers are tipped with whitish. The female is less deeply colored and is spotted with a paler tawny or yellow. The length is 14 to $I 7$ inches, wing, 7 to $7 \frac{\mathrm{T} / 2}{2}$ inches.

The Newfoundland form, known as Allen's ptarmigan, is slightly different, and is described as having a few of the secondaries, quills and wing coverts more or less mottled with dusky, and the shafts black. But this difference may be only seasonal.

Mr. Austin Hobart Clark, who reported on the birds collected and observed during the cruise of the Albatross in the North Pacific, found in southern Alaska a new form of willow grouse, L. l. alexandre. It is somewhat smaller than the willow grouse of the North, I68 
and has a smaller, weaker bill. In full summer plumage its upper parts are deep rich chestnut, thickly and finely waved with black, the tip of each feather narrowly white. The lower throat and fore neck are chestnut, the breast becoming finely cross-lined with black, which increases toward the belly. The sides and flanks are very dark.

The range of the willow ptarmigan, often called the willow grouse, is chiefly confined to the Arctic regions in North America, reaching from Alaska, over much of the British Provinces, to the Atlantic, and rarely straggling south into the United States-Minnesota, New York and New England. Twenty-five or thirty years ago it was not uncommon to find specimens of this bird in the hands of taxidermists in New York, the birds having presumably been shipped to that city from southern Canada.

In many parts of the North the birds are exceedingly abundant and form no inconsiderable portion of the winter food supply of the Indians, while many are killed about the Hudson's Bay posts. Much of what we know about these birds comes from E. W. Nelson, who made his observations on the shores of the Bering Sea, and from L. M. Turner, who studied them in Labrador, with his headquarters at Ungava.

From these observations we can get a good idea of the life of the willow ptarmigan.

In winter these birds seem to be to some extent migratory, and, moving southward--partly, no doubc, in search of food-are found in considerable numbers as 
far south as latitude $50^{\circ}$; yet great numbers remain in the wooded districts of the North as far as latitude $67^{\circ}$.

Mr. E. W. Nelson, whose studies of the fauna of the Northwest and whose ethnological work among the Eskimos of Alaska are so well known, says that in the northern portions of their respective ranges these grouse are summer residents-frequenting the extensive open country and being most abundant along the barren seacoast region of the Bering Sea and Arctic coast, "but in autumn, the last of August and during September, they unite in great flocks and migrate south to the sheltered banks of the Kuskoquim and Yukon rivers and their numerous tributaries. In early spring, as the warmth of the returning sun begins to be felt, they troop back to their breeding grounds once more.

"During a large portion of the year these birds form one of the most characteristic accompaniments of the scenery in the northern portion of Alaska. During the winter season these birds extend their range south to Sitka and Kadiak. ...

"Toward the end of March, as some bare spots commence to show on the tundra, the Eskimos say this will bring the ptarmigan from the shelter of the interior valleys, and their observation proves true. At St. Michael these birds commence their love-making according to the character of the season-on some years by the first of April their loud notes of challenge are heard, but the recurrence of cold weather usually 
puts a temporary stop to their proceedings. About the fifth or fifteenth of this month the first dark feathers commence to appear about the heads and necks of the males. During some seasons the males make scarcely any progress in changing their plumage up to the middle of May, when I have frequently seen them with only a trace of dark about the head and neck. In the spring of 1878 the first males were heard calling on the 26th of April, and on April 27th, in I879, the males were just commencing to moult, showing a few dark feathers, but these seasons were unusually late. In autumn the change frequently commences the last of September and by the first of October it is well under way, the winter moult being completed toward the end of this month. ...

"At the Yukon mouth, on the evening of May 24th, these ptarmigan were heard uttering their hoarse notes all about. As we were sitting by the tent my interpreter took my rifle and, going off a short distance, worked a lump of snow to about the size of one of these birds. Fixing a bunch of dark-brown moss on one end of the snow to represent the bird's head, he set his decoy upon a bare mossy knoll; then retiring a short distance behind the knoll he began imitating the call of the male until a bird came whirring along and taking up the gauntlet lit close by this supposed rival and fell a victim to the ruse.

". . At this time the males were continually pursuing each other or holding possession of prominent knolls, frequently rising thence five to ten yards in 
the air, with quick wing strokes and descending with stiffened wings, with the tips curved downward. While ascending they uttered a series of notes which may be repeated by the syllables $k u-k u-k u-k u$, which is changed as the bird descends to a hard rolling $k r-r-r-r-r$, in a very deep, guttural tone, ending as the bird reaches the ground. Frequently a pair would fly at each other full tilt and a few feathers would be knocked out, the weaker bird quickly taking flight again, while the victor rises as just described and utters his loud note of defiance and victory. On another occasion when the birds are more evenly matched they fight fiercely until the ground is strewn with feathers.

"On May 24th almost all these birds are paired, but some did not complete their nuptials until the first few days in June. This grouse takes but a single mate in northern Alaska, and I am informed by the natives of Unalaska that the same is the case with the rock grouse found on the Aleutian Islands, nor have I ever known of the ptarmigan assembling in numbers about any special meeting place to carry on their love affairs; they scatter about, as previously mentioned, being seen singly here and there on prominent knolls over the flat country. Early in June, rarely so early as the last of May, the first eggs are laid; by June 2oth and $25^{\text {th }}$ the downy young are usually out, and when approached the female crouches close to the ground among her brood. When she sees it is impossible to escape notice she rolls and tumbles away as though 
mortally injured, and thus tries to lead one from her chicks. The young at the same time try to escape by running away in different directions through the grass. At this season the female and male both moult and assume a plumage which differs considerably The young are fledged and on the wing at varying dates through July and are nearly full grown by the first to the tenth of August."

Mr. R. MacFarlane, long chief factor to the Hudson's Bay Company, but now retired and resident in Winnipeg, whose observations on the fauna of many parts of the Far North are so valuable, gives some interesting notes about the willow ptarmigan in one of the regions which he has made famous. He says:

"This species is exceedingly abundant in the neighborhood of Fort Anderson, on the lower Anderson River, and in the wooded country to the eastward. It is not, however, common in the Barren Grounds, especially from Horton River to Franklin Bay, where it is replaced by $L$. mpestris. The nest is invariably on the ground, and consists of a few withered leaves placed in a shallow cavity or depression. The female sometimes leaves it only when almost trodden under foot, in fact, several were swooped upon and caught thereon by hand. They usually begin to lay about the end of May or the beginning of June. The process of moulting, or the gradual assumption of their summer plumage, commences a week or two earlier. The female lays from seven to ten, twelve, and, occasional$1 y$, as many as thirteen eggs, which I find was the 
greatest number recorded; and we had reason to know that some, at least, of the nests were used by ptarmigan several seasons in succession. When very closely approached as stated, the female would frequently flutter off, sometimes spreading her wings and ruffling her feathers, as if to attack or frighten away intruders, and at other times calling out in distressed tones, and acting as if she had been severely wounded.

"In one instance, where an Indian collector had found a nest which contained seven eggs, he placed a snare thereon; but on returning to the spot a few hours afterward, he was surprised to find that six of the eggs had disappeared in the interim, and as no eggshells were left behind they were in all probability removed by the parents to a safer place. The male bird is generally not far away from the nest, and his peculiar hoarse and prolonged note is frequently heard, the more especially between the hours of IO P.M. and 2 A.M. Both, however, displayed great courage and devotion in protecting from capture their young, which we often encountered on our return coast trips.

"About the end of September, during October, and early in November L. lagopus assembles in great flocks, but during the winter it was seldom that more than two or three dozen were ever noticed in single companies. They are, however, most winters very numerous in the neighborhood of Fort Good Hope and other Hudson's Bay Company posts in the Mackenzie River district; but as spring sets in, they begin to migrate northward, and it is very doubtful if many breed 
to the south of latitude $68^{\circ}$, at least in the valley of the Anderson."

The change of summer plumage to that of winter begins on the abdomen and gradually extends over the entire body, the head changing last. This change occurs between September Ioth and the last of October, the young assuming their winter garb a little in advance of the adults. In spring the change is reversed, commencing about the head of the birds and thence passing over the rest of the body. After the head has assumed its summer plumage, the change on the rest of the body goes on very slowly, and in many instances is never perfected, the back and abdomen of the majority of summer specimens being never entirely free from white feathers. The wings remain white throughout the year. There is considerable individual variation in the plumage of adult specimens shot at the same season.

Mr. Charles Sheldon, who spent the winter of 1908 and 1909 on the shoulders of Mt. McKinley, saw there the willow ptarmigan, the rock ptarmigan and the white-tailed ptarmigan. These birds were all abundant, and there was no difficulty at any time in starting out and in the course of a short walk killing with a .22 rifle a sufficient number to last for food during several days.

In spring, at the mating season, the willow ptarmigan was extremely noisy, and at that time was seen much in the trees, often sitting on the topmost spray, from which he uttered his crowing call, and often 
made short flights. Long before the snow disappeared the birds had commenced to assume the lark plumage of summer, the head and neck changing first. The birds were now very noticeable against the snow. The males fought with much energy. After the young had been brought off the males disappeared.

When startled in winter the birds often fly a short distance, and then, alighting on the snow, remain crouched there, perfectly motionless, so that they are extremely hard to see.

As I have often noticed with the white-tailed ptarmigan, the willow ptarmigan, when the wind is blowing fiercely and the snow driving, will often alight on a drift and quickly scratching a hole will crouch in it, thus protected from the wind and the drifting snow, which, however, may sometimes quite cover them over.

In the summer of I899, while the Harriman Alaska expedition was in Yakutat Bay, some of the members who were strolling up a ravine back of the sealing village of the Indians, came upon a female ptarmigan with half a dozen young. The young ones did not at once hide, and one of them was caught in the hand. The mother was anxious and uneasy for her little ones and walked about within three or four feet of us, and when the young one was caught she flew close about the captor. When walking on the ground she clucked like a setting hen, but with a deeper note; and after her young had been released she called to them, warning them to remain hidden, with the same note that a domestic hen uses to warn her chickens that she sees 


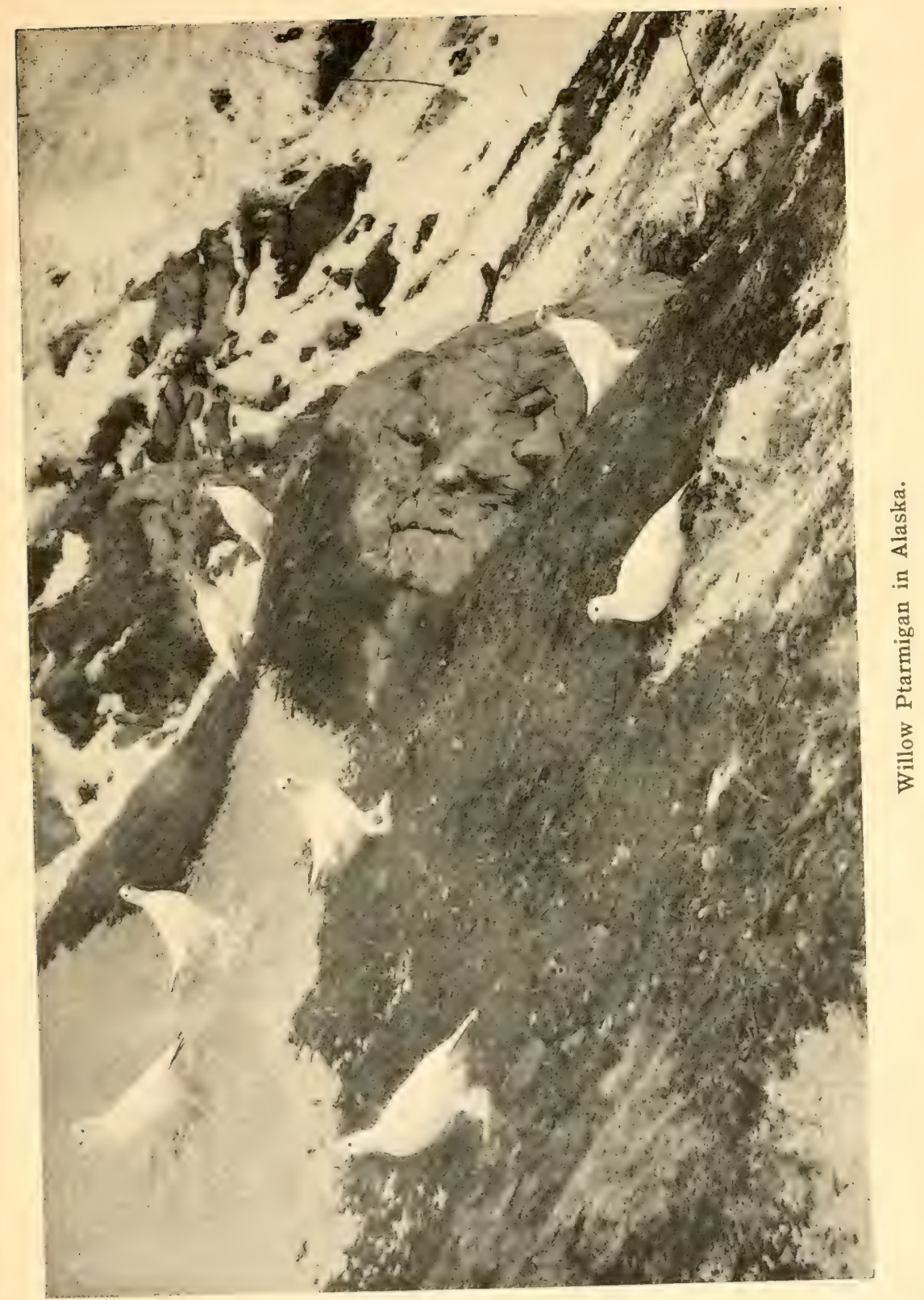



a hawk in the sky. When at last we walked away, leaving the family alone, she also walked off into the alder bushes. The wings and a few breast feathers of this mother bird were white, but the rest of her plumage was black and tawny, much like that of a female spruce grouse.

Of this species at Ungava, in Labrador, Mr. L. M. Turner says:

"In the spring these birds repair, as the snow melts, to the lower grounds and prepare for the nuptial season. About the roth of April they may be heard croaking or barking on all sicles. A male selects a favorable tract of territory for the location of the nest, and endeavors to induce a female to resort to that place. He usually selects the highest portion of the tract, whence he launches into the air, uttering a barking sound of nearly a dozen separate notes, thence sails or flutters in a circle to alight at the place whence he started, or to alight on another high place, from which he repeats the act while flying to his former place. Immediately on alighting he utters a sound similar to the Indian word, chu-xwan. (what is it?), and repeats it several times, and in the course of a few minutes again launches in the air. Early in the morning hundreds of these birds may be heard, continuing until nearly eleven o'clock, when the bird then becomes silent until after three o'clock, when he again goes through the same performance, though with less vigor than in the morning. In the course of a few days a female may be found in the vicinity. The 
actions of the male are now redoubled, and woe be to any bird of his kind which attempts to even cross his chosen locality. Battles ensue which for fierceness are seldom equaled by birds of larger size.

"In the vicinity of Fort Chimo the nesting of this species begins during the latter part of May. The nest is usually placed in a dry spot among the swamps, or on the hillsides where straggling bushes grow. The nest is merely a depression in the mosses and contains a few blades and stalks of grass, together with a few feathers from the parent bird, which is now in the height of the moulting from the winter to the summer plumage.

"The first eggs obtained were two on June I, I884, this being the earliest record at Fort Chimo. The number laid for a set varies greatly in different localities. At Fort Chimo seven to nine is the usual number, although in exceptional instances as many as eleven and rarely thirteen may be found.

"While I was at St. Michael (Norton Sound, Alaska) I frequently found nests containing as many as fifteen, and several times found seventeen. I was there informed that over twenty eggs had been taken from a single nest. On neither side of the continent did I hear that more than one female deposited eggs in the same nest. I can affirm that a clutch of seven eggs may be taken, and if the nest be not disturbed, the female will deposit nearly the same number again. These may again be taken, and not over three eggs will be deposited, and if disturbed a third time she will 
lay no more unless she selects a new location, which, of course, would be difficult to ascertain.

"I cannot speak accurately on the subject, but think that seventeen days are required to incubate the eggs. On the 2oth of June I obtained a young bird of this species, which was less than forty-eight hours out of the shell. This was the earliest record. Thousands of these young must perish annually, either from the cold rains or from their parents being killed for food. ... After the middle of August the birds have acquired a good size and are then feeding on berries of various kinds. They are then quite tender, of nearly white flesh, and when properly prepared form a pleasant food for the table. The young birds of the year attain their full growth by the first of November."

It thus seems that this ptarmigan is monogamous, a pair mating and remaining together through the breeding season, the male taking part in the care of the young, showing a strong attachment for them and being devoted to the female.

The food of this species consists chiefly of the buds and leaves of various willows and birches, as well as berries of different sorts, which during the summer are exceedingly abundant in that country. The eggs, like those of other ptarmigan, are cream-colored as to groundwork and are marked with blotches, spots and cloudings of reddish and dark brown, often entirely covering the ground color. Captain Bendire tells us that all these markings are readily removable from the freshly laid egg. 
The form of willow ptarmigan, known as Allen's ptarmigan, was described from Newfoundland by Dr. Stejneger nearly twenty-five years ago. The differences between it and the bird of the mainland are trifling, being chiefly confined to the color of the shafts of primaries and secondaries, which are black. This is still a common bird of Newfoundland, where it is often called "partridge" by the settlers, and where, in more remote districts, it still offers very good shooting, though nowhere nearly so abundant as formerly. It lives on the barrens, feeding on seeds and berries, and in winter on the buds of alders, willows and birches. It breeds on the ground among the spruces.

Perhaps no writer has lived longer in the region inhabited by the willow grouse than Napoleon $\mathrm{A}$. Comeau, who, in his recent work, "Life and Sport on the North Shore of the Gulf of St. Lawrence," gives some interesting notes on the species. He says:

"Of all the above species [of grouse], the willow ptarmigan is by far the most abundant, and of considerable value as an article of food during its years of passage. It is an irregular migrant, in this wise, that it does not come regularly every season, like most other birds, and sometimes we may be three or four years without seeing any. I have gathered considerable data on this subject, and I find that about every tenth year is one of great abundance. Here are some of the dates: 1863 and I864, extremely abundant; I867, disappeared this year; I87 I, a few were seen this year, but none between I 867 and I $87 \mathrm{I} ;$ I 872 and 1873 , 
very numerous again and total disappearance in 1876 ; I882, a few observed; I883, I884 and I885, great abundance; I887, disappeared entirely; I89I, a few seen, gradually increasing each year till I895, when there were considerable quantities; I897, none; I903 and I904, abundant, and a few seen every winter since to date, 1909.

"At one time it was supposed that these years of abundance on the coast were due to heavy sleet in the interior, covering up all the buds and preventing the birds from feeding, and thus forcing them to seek food elsewhere. I have noticed that this will affect them to some slight extent, but the dates given show too much regularity for this to be the true cause. My belief is that it is due to the food supply. Having examined thousands of the crops of these birds $I$ found that over ninety per cent. contained the buds of a species of willow, popularly known here as pussy willow, Salix arctica? The balance were buds of the birch, poplar and the mountain ash and its berry. I also noticed a few seeds that I could not identify.

"After a year or two of great abundance, all the willows are destroyed by the breaking of the tips and the buds, and the shrub takes about two years to recover, which is generally by fresh sprouts from the roots. As the food fails the birds have to move elsewhere. It would, therefore, appear from my. data that it takes about ten years to go around their circle of migration. I say circle because their line of flight seems to indicate this. They first appear on the 
Labrador coast line flying south, and continue so till they reach our large rivers, like the Manicouagan, Bersimis and the Saguenay, seldom going west of this last. These large rivers are followed up in a west and northwesterly direction, the birds scattering inland over a tract that includes the Lake St. John and Lake Mistassini region, then down to the shores of Hudson's Bay, where Dr. Milne and Mr. Peter McKenzie told me they flew north all along the coast line to Ungava, then south again to the Labrador, and so on. The range of the flight on this side of Hudson's Bay would cover about ten degrees of latitude and in round figures form a circle around this big peninsula of about two thousand miles. As this immense body of ptarmigan moves on during a season of abundance, stragglers are left behind, which breed, giving another and lesser batch to migrate the second year, when fewer stragglers are left, till the third or fourth season, when no more are seen for a time. Their total absence varies from four to six years. They seldom or never breed in the lowlands, always seeming to prefer high and bare mountainous sections. In June, I893, I saw a pair several times. They probably had their nest within a mile of our house (Godbout). The earliest appearance of any large migration was October 29, 1872, but as a rule it begins here from the I 5 th of November to December.

"The regular flight along the seashore lasts about four to six weeks. After that the birds seem to scatter inland and feed. When on the move they fly very 
early in the morning, sometimes so early that it is impossible to distinguish them unless there happens to be some dark background. The morning flight, when abundant, will last an hour or two. The size of the flock varies, in ordinary seasons, from ten to fifteen or twenty. In years of great abundance, flocks of a hundred or more are common. On the I4th of December, I885, I saw at Trinity Bay, six miles east of Pointe des Monts, one flock which contained many thousands. It was a continuous mass of birds over half a mile long and from sixty to a hundred yards wide. I have never seen anything approaching this before, nor have I since. When in large flocks they are, as a rule, shy, especially if the weather is very cold or windy, and will rise long before one gets within ordinary range. On the wing, however, they do not seem to mind anything in their way, flying over and around one without apparently noticing him. They are very strong on the wing, not any faster than the ruffed grouse, but capable of sustaining much longer flights, occasionally going five or six miles without resting.

"In small bunches and in snowy and mild weather they are quite tame, and when feeding in the thick willow bottoms it is hard work to get them to rise out of them. After feeding they congregate around some clump of willow, and scratching a small hollow in the snow, will lie perfectly still for hours, the top of the head just level with the snow, the black eye and beak alone betraying their presence. The popular idea of their diving in the snow to escape pursuit is most 
ridiculous. At night they will occasionally burrow in the snow, but only during high winds or very cold weather, the usual way of resting being the small hollow mentioned. Another rather remarkable thing in connection with ptarmigan is the apparent disproportion of the sexes. Out of the many thousands that I have killed and examined, only about twenty-five per cent. were males. In winter they prefer low valleys and the borders of rivers and lakes and dense willow patches, but as the season advances they seek the higher ranges, choosing those that face the midday sun. When flying over water, as they often do in crossing bays or large rivers, they keep very near the surface, just about a foot or so above it. Over land the reverse is the case, for sometimes they rise high over the tops of the tallest trees. The most remarkable thing about them, however, is their seasonal change of plumage. In I 885 I had the pleasure of attending the meetings of the American Ornithologists' Union, in New York. At one of the meetings a very interesting paper was read by Dr. Stejneger on this subject. The doctor exhibited two specimens which came from Newfoundland, and which, in his opinion, were a subspecies confined to the island. This distinction was based particularly on the coloration of the primaries. The birds shown had nearly all the tips of the primaries black. Since my return I have taken special pains to examine a great number of birds. On those killed prior to I 5 th November I found the same coloration, more or less, as on the species shown, but 
after that date there was a gradual whitening of the primaries, and in many cases only the shafts were white.

"During the last two migrations, taking the best years, I895 and 1904, I took some trouble to try and find out approximately how many birds were killed between certain points. During the first year mentioned, between Mingan and Godbout, I75 miles of coast, 30,000 were killed. In the second (I904), I4,000, but I am sure that during I 885 nearly 60,000 must have been shot or snared. When a flight begins, every man, woman and boy able to handle a gun is out. To avoid accidents, which are very rare indeed, each gun occupies a certain point or station, and shoots at all the birds that pass or light in his vicinity. The ladies keep watch of those that may light near the houses. The bags vary, of course, according to the skill of the shooter and his method of shooting. If he is there for business he will take all the pot shots. He can frequently get five or six in one shot. I have seen fourteen killed in a single shot. A few will only shoot on the wing, but there are many days when the wing shooter comes out ahead. The biggest bag I ever made (it was in I885), shooting at flying birds, was eighty-two brace in one morning. At Caribou Islands, that winter, nets were tried, but they were not very successful, more being got by shooting. Indians frequently snare them by setting their snares around willow clumps, where the birds feed. It is a very simple arrangement. A twig is stuck in the snow, a twine 
snare is tied to it, a very light support placed under it to hold it in position, and it is ready. In walking around, the bird runs into it, then tries to rise on feeling the snare, only to tighten the noose. There is a little fluttering, and it is all over." 


\section{ROCK PTARMIGAN.}

Lagopus rupestris.

Lagopus rupestris reinhardi.

Lagopus rupestris welchi.

Lagopus rupestris nelsoni.

Lagopus rupestris atkensis.

Lagopus rupestris torensendi.

Lagopus rupestris evermanni.

Lagopus rupestris chamberlaini.

Lagopus rupestris kellogo.

Lagopus rupestris dixoni.

The bill of the rock ptarmigan is much more slender than that of the willow ptarmigan, and the bird is somewhat smaller, measuring from $I_{3}$ to $143 / 4$ inches. In winter the bird is white, with black tail; but a line running from the eye to the bill is also black. It is said that the female does not always have this black spot covering the lores.

In summer the male is grayish brown, the feathers being crossed with fine black lines, which tend to form irregular zigzag bars. The shoulder feathers, or scapulars, are chiefly black, which gives the effect of large black spots on the back. The quills of the wing - primaries and secondaries-and the outer tertiaries 
are white. The lores and top of the head are black, the ends of the feathers on the latter being tipped with brown. Breast regularly barred with blackish and light brown, and the sides the same, but with finer black bars; beneath, white.

The summer plumage of the female is brighter, yellowish or reddish, spotted and barred with black, and having the quills and secondaries always white. The lower plumage is somewhat paler and grayer; the dottings and barrings are black, often quite fine; yet the barrings show a tendency to form spots and heavier bars. The head and neck are more yellowish and barred with dusky.

The rock ptarmigan, in its various forms, is scattered over Arctic America in general, except the extreme north, including Greenland and the Aleutian Islands, and is found southeast as far as the Gulf of St. Lawrence, occurring on Anticosti Island.

Mr. Nelson reports it a common resident of the mainland of Alaska, where it inhabits the higher ground during the summer, but is driven down by winter to the lower levels. Its habits do not appear to differ greatly from those of the common willow ptarmigan. It breeds in large numbers on the Barren Grounds, from which Mr. MacFarlane reported on its breeding habits, nests and eggs. It does not appear to be so prolific a bird as the willow ptarmigan, its eggs being fewer in number and apparently running from nine down to four or five. The female sits closely on her eggs, and her color harmonizes so well with that, 
of the surrounding vegetation that usually when discovered she is seen only by accident.

In Alaska the eggs are laid in May and in the Barren Grounds somewhat later, usually between the middle of June and July. The eggs are quite like those of the willow ptarmigan, but are slightly smaller. The ground color runs from cream color to yellowish, and the spots and blotches vary from a dark brown to a claret red. Sometimes these spots are so numerous as almost to hide the ground color.

Reinhardt's ptarmigan, a sub-species of the rock grouse, is found in Greenland and throughout Labrador, and Mr. L. M. Turner, whose notes on the birds of Labrador and Ungava are so familiar to ornithologists, tells us about all that is known of it. He says that it prefers open ground, and rarely enters even the skirts of the wooded tracts.

"The mating season begins in May, and during this period the male acts in the strangest manner to secure the affection of its mate. He does not launch high in the air and croak like the willow ptarmigan, but runs around his prospective bride with tail spread, wings dragging like those of the common turkey, or else with head and neck stretched out and breast in contact with the ground, pushing himself in this manner by the feet, which are extended behind. The male at this time ruffles every feather of his body, twists his neck in various positions, and the supra-orbital processes are swollen and erect. He utters a most peculiar sound, something like a growling kurr-kurr, and as 
the passion of the display increases, the bird performs the most astonishing antics, such as leaping in the air without effort of wings, rolling over and over, acting withal as if beside himself with ardor. The males engage in most desperate battles; the engagement lasts for hours, or until one is utterly exhausted, the feathers of head, neck and breast strewing the ground. A maneuver is for the pursuing bird to lead the other off a great distance and suddenly fly back to the female, who sits or feeds as unconcerned as it is possible for a bird to do. She acts thoroughly the most heartless coquette, while he is a most passionately devoted lover. $\mathrm{He}$ will die rather than forsake her side, and often places himself between the hunter and her, uttering notes of warning for her to escape, while attention is drawn to him, who is the more conspicuous.

"When the young are with the parents they rely upon their color to hide themselves among the nearly similar vegetation from which they procure their food. I am certain I have walked directly over young birds which were well able to fly. If the parent birds are first shot, the entire number of young may be secured, as they will not fly until nearly trodden upon, and then only for a few yards, while they may easily be seen. I have found on two occasions an adult female with a brood of thirteen young. All of the flocks were secured without trouble. At other times only three or four young would be found with both parents. The young are very tender when first hatched; no amount of most careful attention will induce them to eat, and 
after only a few hours' captivity they die. I never could keep them alive above twelve hours. The changeable weather, sudden squalls of snow or rain, must be the death of scores of these delicate creatures. Their note is a soft piping pe-pe-pe, uttered several times, and has the same sound as that of the young of the bobwhite (Colinus virginianus)."

For the first few weeks of their life the young of this species cannot be distinguished from those of the willow ptarmigan, but when a month old they may be readily told apart by the bill.

The food of this species consists of insects, berries, leaves and buds of the birch and willow. Mr. Kumlien, at Cumberland Sound, shot one whose crop was full of moss.

Welch's ptarmigan, described by Mr. Brewster from Newfoundland, is reported as a highland form of the rock ptarmigan, and confined to the sides and summits of rock hills and mountains in the interior of Newfoundland. The rock ptarmigan is a very local bird, and for the most part spends its life on or near the hills where it was reared. It has been spoken of as a truly alpine species, rarely found below the line of stunted black spruces, except in the depth of winter, when they descend to the lowlands and sometimes mingle with the willow grouse. The settlers call it mountain partridge to distinguish it from the willow grouse, known as partridge.

Nelson's ptarmigan is another form of the rock grouse, which is confined to the islands of Unalaska, 
Akutan and Unimak of the Aleutian group. It spends most of the time on higher ground, but at the breeding season comes down to the narrow valleys to rear its young. The nest is usually placed in tall grass in some valley or on the open tundra.

Turner's ptarmigan, another subspecies, is found at Atka, one of the islands of the Aleutian chain. It occurs also on Amchitka Island. The bird is larger than the mainland form, and is quite numerous on these islands. Mr. Turner reports the eggs as from eleven to seventeen in number. The habits of the subspecies are not known to differ from those of the other forms of this ptarmigan.

Townsend's ptarmigan from Kiska Island, Evermann's ptarmigan from Attu Island, Chamberlain's ptarmigan from Adak Island, Dixon's ptarmigan from the Sitkan Islands, and Kellog's ptarmigan from Montague Island, complete the list of closely related forms from the Alaskan Islands, where this species seems to have been very easily influenced by local conditions. 


\title{
WHITE-TAILED PTARMIGAN.
}

\author{
Lagopus leucurus. \\ Lagopus leucurus peninsularis.
}

Winter plumage snow-white throughout; the bill and eyes being the only dark spots to be seen. The summer plumage is buff, or, later in the season, clay color, coarsely barred with black on a pale ground. There is little difference between the male and the female. The tail is always white.

In the young the tail feathers at first are not white, but are mottled with brownish. They become white with moulting, however.

The sub-species, pcninsularis, inhabits the alpine mountains of central Alaska, northern Yukon, N. W. Mackenzie, south to Cook Inlet, Kenai Peninsula and southern Yukon.

In all America, the especial home of the grouse, there is no prettier member of this family than the white-tailed ptarmigan. Like all its kind, it loves the cold and snow, but, unlike the other American memhers of the group, it substitutes altitude for latitude and is an inhabitant of the lofty mountains of the Vest, from central Alaska and northern Yukon south to Washington and New Mexico. Here on the very edge of perpetual snowfields, not far from some brawl- 
ing ice-fed torrent, and within the sound of the roar of avalanche and the thunder of glacier, the little ptarmigan spends his life, seldom disturbed by enemies.

In summer he wears a livery of black and clay color, which harmonizes so well with the rocks among which

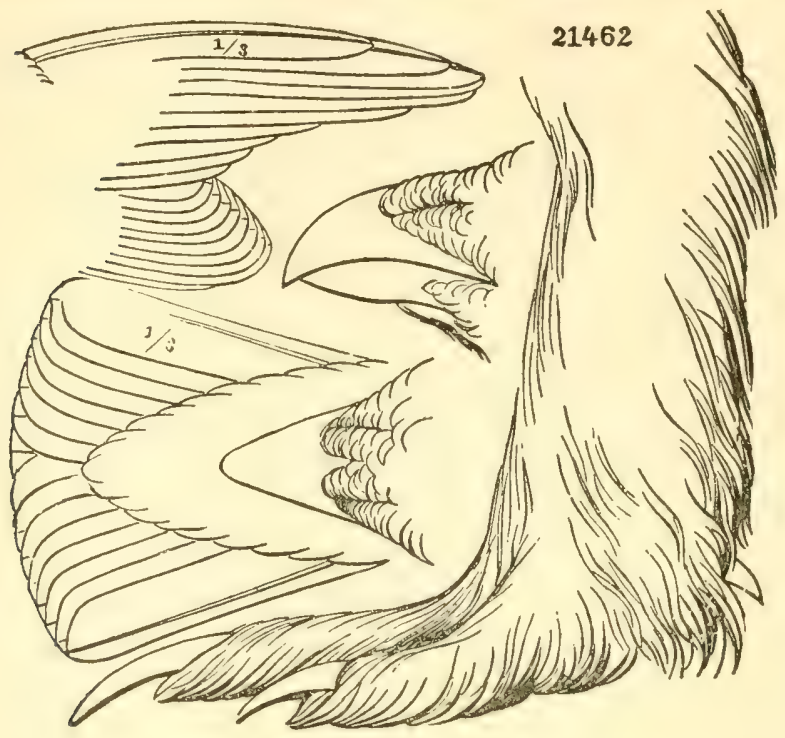

WHITE-TAILED PTARMIGAN

his life is passed that it is most difficult to see him, if he wishes to remain unseen and does not move; while in winter, as he journeys over the frozen wastes, his plumage is as white as the snows on which he walks. His must be a contented, care-free life, for he has few enemies to fear. The sneaking coyote and the stealthy wild cat seldom visit his mountain soli- 
tudes. Rarely the eagle's broad pinions cast their dark shadow over snowfield and rock slope, but the eagle is generally in search of larger game, the tender young of the big horn or of the white goat. The great bears that in early summer prowl over the range, looking for the young grass or digging out mice, or later picking the luscious huckleberries, do not give a thought to the ptarmigan, unless by chance they stumble on her nest, when it suffers the fate of every thing eatable that comes in Bruin's way.

Of all the animals of the mountains, the one that the ptarmigan has most to fear is perhaps the pine marten. He is always traveling about, alow and aloft; equally at home among the trees of the forest and the rocks of the peaks, always hungry, always searching for food; and, while it may be doubted whether he destroys many full-grown ptarmigan, we may feel sure that he compasses the death of many young and pillages many a nest.

Although the white-tailed ptarmigan is abundant enough in the high mountains which it inhabits, it is scarcely known at all to sportsmen. Only the hardy spirit who climbs above timber line in search of sheep or goats, or that other enthusiast whose highest pleasure it is to reach the summit of the loftiest mountain peaks, ever reaches the home of this bird; and as neither of these ever burdens himself with a shotgun, it is almost never killed for sport. In Colorado, where many prospectors and miners carry on their operations far above timber line, the ptarmigan is often killed for 
food, but in other parts of the West man interferes but little with the abundance of this species.

This ptarmigan is found in considerable numbers above timber line on most of the mountains of western America. It does not occur in the Sierra Nevada, nor in the Cascades south of Washington. It is nowhere very abundant, though I have seen them, in autumn, in flocks of twenty-five or thirty, and recall an afternoon when, on Mount Jackson, in Montana, two of the party secured twenty-two of the birds. Yet, as a rule, they are nowhere very common, a single brood often seeming to occupy its own range of territory, which is not encroached on by others. I have not seen them in large flocks as mentioned below by Mr. Trippe.

The nest of the white-tailed ptarmigan is built high up on the motntain-side above timber line, and may be located anywhere among the loose stones and rocks. A little depression is perhaps scratched out near a patch of grass or weeds, and here the mother bird deposits her eight or nine eggs, buff in ground color, sometimes spotted with many small reddish or brown dots, or, again, peculiarly blotched with larger markings of the same color. The nest is usually quite in the open, but the grayish mother bird so closely resembles the stones among which she nests as readily to escape observation. Moreover, the confiding nature of the bird gives her such courage that she will remain on the nest, unscared even by the close approach of some great danger. 
Mr. A. W. Anthony wrote to Captain Bendire: "Twice have I escaped stepping upon a sitting ptarmigan by only an inch or so, and once I reined in my horse at a time when another step would have crushed out the life of a brood of nine chicks, but an hour or so from the egg. In this case the parent crouched at the horse's feet and, though in momentary danger of being stepped on, made no attempt to escape until I had dismoanted and put out my hand to catch her. She then fluttered to the top of a rock a few feet distant and watched me as I handled the young, constantly uttering low, anxious protests. The chicks were still too young to escape; mere little wet bunches of down, that stumbled and fell over one another when they attempted to run.

"Miners in whom I have confidence told me that they have lifted sitting ptarmigan from the nest and handled the eggs, while the bird stood but a few feet distant, watching her treasures and uttering an occasional squeak like a sitting hen. One which had her nest near the trail between the cabin and the mine was annoyed in this way so often that she would attempt to regain the nest while the eggs were being handled, and had to be frequently pushed aside. She never failed to peck at the hand and utter her protesting $k i-r-\gamma-r-r$ whenever one attempted to touch her, and made no attempt to fly away."

All the evidence given by people who have found the nests of this bird indicates that the sitting female 
is no wilder than the average domestic hen in the same situation.

The following very interesting account of this bird appears in Dr. Coues' "Birds of the Northwest," for which it was prepared by Mr. Trippe; it relates entirely to the species in Colorado: "The white-tailed ptarmigan is a very abundant bird on the main range, living entirely above timber line the year round, except during the severest part of the winter, when it descends into the timber for shelter and food, occasionally straggling as low as I0,000 feet. It begins to change color about the middle of March, when a few specks of blackish brown begin to appear in the plumage of the oldest males, but the change is very slow, and it is late in April before there is much black visible, and the close of May or early in June before the summer plumage is perfect. The ptarmigan builds its nest in the latter part of June and commences hatching toward the close of the month, or early in July. The nest-which is almost always placed on or near the summit of the ridge, or spur, many hundred feet above timber line--is merely a depression in the ground, lined with a few straws and white feathers from the mother's breast. The eggs are eight in number, of a light buff brown; thickly sprinkled with spots of dark chocolate brown, somewhat thicker at the larger end. While on her nest the bird is very tame. Once, while walking near the summit of the range, I chanced to look down and saw a ptarmigan in the grass at my very feet; at the next step I should have trodden upon her. 
Seeing that she did not appear frightened, I sat down gently, stroked her on the back, and, finally, putting both hands beneath her, raised her gently off the nest and set her down on the grass, while she scolded and pecked my hands, like a setting hen, and, on being released, merely flew off a few yards and settled on a rock, from which she watched me till I had gone away. Late in July I came across a brood of young ones, apparently not more than four or five days old. They were striped with broad bands of white and blackish brown, and looked precisely like little game chickens. The mother flew in my face and hit me with her wings, using all the little artifices that the quail and partridge know so well how to employ, to draw me away; while her brood, seven or eight in number, nimbly ran and hid themselves in the dense grass and among the stones. On another excursion above timber line, toward the close of August, I found most of the young ones nearly grown, and strong on the wing; but one brood was of the size of quails, showing that some birds must begin breeding much later than others. or that they: occasionally raise two broods. These little ones were colored much like the older birds, having blackish-brown bodies and pure white tails. About the first of September the ptarmigan begins to change color again, but, as in the spring, the process is very gradual, white feathers appearing one by one and taking the place of the dark ones. The white on the lower parts enlarges first, then the white areas on the wings, and next, white specks appear on the upper 
parts, becoming larger and more numerous as the season wears on; but so gradual is the change that a month after it begins there is not much difference in the plumage perceptible, the general aspect being that of summer. There is much more of the light rufous, however, and the appearance is lighter and grayer, as though bleached. The dark areas predominate, however, throughout October, and, as I have been informed by. persons who have killed them throughout the year, it is late in December or January before they become pure white, some few birds showing occasional dark spots even throughout the latter month.

"The ptarmigan feeds upon the leaves and stalks of various alpine plants, being particularly fond of those of a species of Cassia, the flowers of which I have frequently taken from its crop. It also lives largely upon insects, and in winter is said to subsist on the buds and leaves of the pines and firs. Its flesh is lightcolored, though not as white as that.of the gray grouse, to which it is usually considered inferior for the table. In localities where it is seldom molested, it is very tame, and I have been informed by persons whose word is worthy of belief, that they have frequently killed it with sticks; but when persistently persecuted it soon becomes wild and leaves the range of a shotgun with surprising quickness. After hunting several large flocks for three or four days, they grew so shy that it was difficult to approach within gunshot, although at first they had been comparatively tame. Nimble of foot, the ptarmigan frequently prefers to run away on 
the approach of danger rather than take wing, running over the rocks and leaping from point to point with great agility, stopping every little while to look at the object of alarm. I have sometimes chased them half a mile or more over the rocky, craggy ridges of the main range, without being able to get within gunshot or force them to take wing. The flight of the ptarmigan is strong, rapid and; at times, sustained for a considerable distance, though usually they fly but a few hundred yards before alighting again. It resembles that of the prairie hen, consisting of rapid flappings of the wings, alternating with the sailing flight of the latter bird. The note is a loud cackle, somewhat like the prairie hen's, yet quite different, and when uttered by a large flock together, reminds one of the confused murmur and gabble of a flock of shore birds about to take wing. It is a gregarious bird, associating in flocks throughout the year, except in the breeding season. The different broods gather together as soon as they are nearly grown, forming large flocks, sometimes of a hundred or more. The colors of this bird closely resemble those of surrounding objects at all seasons of the year. In its summer plumage of speckled black and gray it is very difficult to detect while sitting motionless among the gray and lichen-covered rocks. The ptarmigan is apparently well aware of this, and often squats and remains quiet while one is walking past, trusting to its resemblance to the surrounding rocks to escape observation. So perfect is this resemblance that sometimes, 
on seeing one alight at a certain spot, and withdrawing my eyes from it a moment, I have been unable to find it again, although I knew the exact place where it sat, until a movement on the part of the bird betrayed its position. In summer the white areas of the plumage are completely hidden while the bird is squatting, although plainly visible while on the wing; in winter the first appearing black specks are concealed beneath the white feathers, and at this period, as I am informed, it is almost indistinguishable from the snow. On being pursued, it will dive into the snow and reappear at a considerable distance."

My experience with this bird has been chiefly in Wyoming, Montana and British Columbia, and usually in the autumn. In the month of November some change in the plumage will be noticed, though this is chiefly in the reduction of the dark-colored areas, rather than in the appearance in them of white feathers. Where little disturbed by man, the birds pay but slight regard to the presence of the hunter, and feed along in a close flock without scrutinizing him. If he ventures so near as to alarm them, and this sometimes may be within a few feet, they may rise on the wing against the stiff breeze and sail along for a few yards, looking much like a flock of domestic pigeons, to alight after going a very short distance. If the spot where they strike the ground is exposed, and the wind is blowing, the birds crouch flat on the ground, head to the wind, or those that have alighted near stones or rocks projecting from the earth, run and 


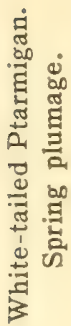



crouch behind them; or, if they alight on a snow bank, they quickly scratch out for themselves a little cavity in the snow, large and deep enough to contain the body, so that the wind blows over them.

On the other hand, in Montana, among the high mountains of the Saint Mary's region, where hunters and mountain climbers are often seen, these birds are sometimes quite wild, rising at a considerable distance with a loud cackle, and flying a quarter of a mile to alight again on some prominent rock, upon which they run about with tail erect and head thrown back, cackling in alarm, and ready at an instant's notice to take to wing again and fly still farther. It is only in this region that I have pursued them with a shotgun, and here they are as quick on the wing and as hard to hit as any of the grouse. Sometimes, when following scattered birds along the rough mountainside, they would pitch down past me from the rocks on which they had perched, with a flight not less rapid than that of the New England ruffed grouse, as he darts down from the top of some pine tree in which he has hidden himself.

Two or three years ago, Joseph Kipp, of Montana, while crossing from the west to the east side of the range, through the Belly River Pass, in July, came upon a brood of half-grown ptarmigan. The mother attacked him vigorously, and was so persistent that he caught her and several of the young, and carried them with him for half a day, when he let them go again, because he had nothing which they could eat. 
It is hardly to be stipposed that these birds would do well on food other than that to which they are accustomed in their home among the high mountains, and any attempt to domesticate them would be foredoomed to failure. It is not improbable that if some one who resided high up in the mountains should try to rear the young he might succeed, but they could not be taken away from the mountains where they belong.

In summer or autumn single birds are often met with high up on the peaks, presumably the males whose mates are then busy with their nests or young, and these individual birds usually seem wild. They will often stand and look until quite closely approached, and then run swiftly fifteen or twenty yards, and then stopping, stand erect and watch until again approached.

While nowhere very abundant, the white-tailed ptarmigan is yet numerous on all the higher mountains which suit the requirements of its life. Half a dozen broods may be found within a range of two miles along the mountain-top, while the number of eggs varies from five or six to fourteen or fifteen. Occasionally, at the approach of winter, a considerable number of the birds will be found together, but I have not seen more than twenty-five or thirty in a flock.

Though, in summer, insects, flowers of the heather, berries and seeds undoubtedly constitute a large part of the white-tailed ptarmigan's food, nevertheless I believe that at all seasons they feed to a considerable extent on the buds and tips of the willow, the largest shrubs which grow near the tops of the mountains. On 
many occasions I have examined their craws and have usually found them stuffed with these willow buds. None of these examinations, however, has been made later than December.

Of all our grouse the white-tailed ptarmigan is probably the one least exposed to persecution by man. No doubt some are killed by lynxes, martens and weasels, but on the whole its enemies must be few in number. 


\section{PINNATED GROUSE.}

Tympanuchus cupido.

Tympanuchus americanus.

Tympanuchus americanus attwateri.

Tympanuchus pallidicinctus.

The familiar prairie chicken or prairie hen of a generation ago was the pinnated grouse, once so abundant in Illinois, Indiana, Kentucky and to the westward. It is remembered by older readers as abundant in our markets, where it sold for seventy-five cents per pair. In later years the term prairie chicken has been applied equally to the sharp-tail grouse, a species of more western distribution; and, generally, in the western country, any grouse found in the open are called "chickens."

The pinnated grouse include four forms, grouped together under the genus Tympanuchus, a name which refers to the inflatable sac on the neck of all these grouse. All these forms are so similar as hardly to be distinguished by any one save a practiced ornithologist. Birds of this group were formerly abundant on the Atlantic coast, as well as throughout much of the western country until the semi-arid plains were reached. So far as we know, their western boundary, roughly stated, was western Minnesota, eastern Ne206 
braska and Kansas, the Indian Territory and western Texas.

Birds of this genus are brownish or clay color, crossbanded by dark brown or black. The tail is short and rounded, and the sides of the neck are provided with

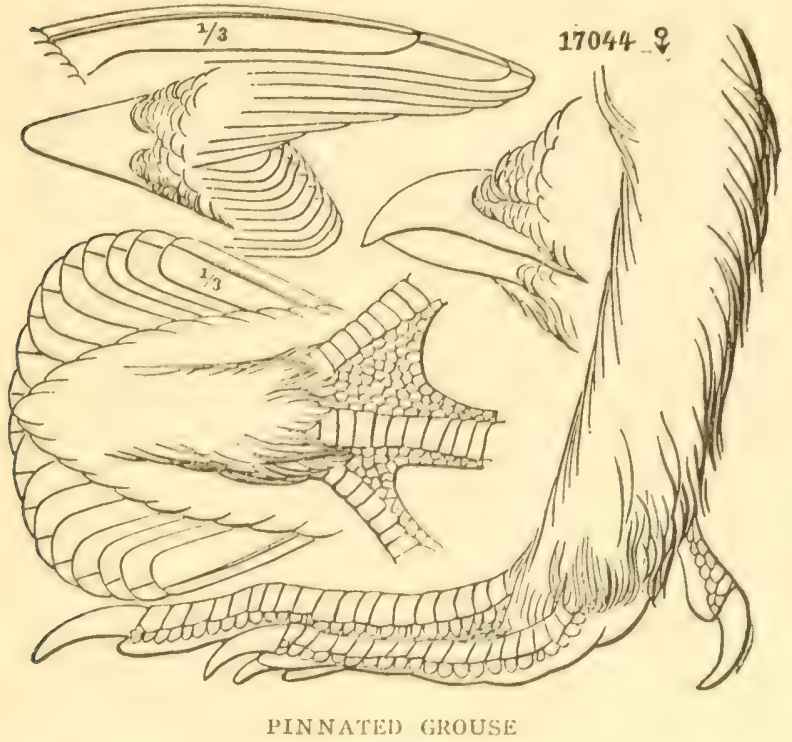

conspicuous wing-shaped tufts of straight, stiff black feathers, beneath which is a naked inflatable air sac.

In greater detail the color above is pale brownish, barred with dusky and buff; beneath, paler, broadly barred or banded with brown. The quills of the wing are gray or brownish, with buff or whitish on the outer webs. The chin, throat and cheeks are buff, 
the cheeks marked with brownish spots. A darkbrown stripe runs from the corner of the mouth under the eye and across the ear, and above this is a stripe of buff. The black tufts of feathers on the side of the neck are stiff and narrow, the longest ones being two and a half inches. The tail feathers are blackish, tipped with white; the under tail coverts whitetipped. In the female the neck tufts are smaller, usually less than two inches in length, and the tail feathers are barred with light brown.

In the ordinary prairie hen of the Mississippi Valley, Tympanuchus americanus, the scapulars are without white dots near the ends, and the neck tufts of the male are composed of more than ten narrow feathers, whose edges are parallel and whose ends are rounded, or sometimes almost square. The feathered young are more or less dotted with patches of white and black and the top of the head is reddish brown. The bird's length is from eighteen to nineteen inches for the male, and a little less for the female.

The Martha's Vineyard heath hen, T. cupido, is slightly smaller than the western prairie hen, has large and noticeable spots of whitish at the end of the scapular feathers. The neck tufts of the male have not more than ten of the narrow feathers, all of which are sharply pointed.

The lesser prairie hen, $T$. pallidicinctus, is also slightly smaller than the Mississippi Valley prairie hen, and is recognizable because each dark bar across the plumage consists of a continuous brown bar en- 
closed between narrower black feathers; in other words, the edges of this dark bar are black, and this is true all over the bird. The lesser prairie hen is found in Kansas, southwestern Missouri, Oklahoma and west central Texas.

Along the coast region of Texas and southwestern Louisiana is found a well-marked race of pinnated grouse, which Major Bendire named in honor of Mr. H. P. Attwater, who brought the bird to the attention of ornithologists. It is about the size of the lesser prairie hen, but has the foot feathered only on the upper two-thirds of the tarsus; the tips of the long feathers of the wing-like neck tufts are square.

THE HEATH HEN.

The bird of the Atlantic coast now known as the heath hen is almost extinct, the only existing colony being on Martha's Vineyard, an island off the coast of Massachusetts. It was formerly found in Massachusetts, Connecticut, Long Island, New Jersey, Pennsylvania, Maryland and Delaware, but has longbeen exterminated from most of these regions.

Thus, long before any of the other so-called prairie grouse had been discovered, the pinnated grouse was well known. Indeed, it may very well be that when the Pilgrim Fathers landed at Plymouth Rock, the first flesh meat that they tasted in the new country was the coast form of what in later times was called prairie hen or prairie chicken, then known as heath cocke or heath 
henne, later changed in pronunciation to hêth'n. The bird was long abundant in Massachusetts, in the open, brushy country around the seacoast, where, no doubt, it fed, as do its descendants to-day, at Martha's Vineyard, on acorns, berries, grass and insects. It was well known in New England in the first quarter of the nineteenth century, but disappeared soon after that.

The old New England writers speak of the heath cocke as common, so that, according to Wood, "Hee that is a husband and will be stirring betime may kill halfe a dozen in a morning."

Mr. William Brewster, in his interesting and complete paper, entitled "The Birds of the Cambridge Region of Massachusetts," says:

"I have been permitted to quote the following interesting passage from 'Notes of conversations with Eliza Cabot, written down by her son, J. E. C. (abot), and printed for private circulation in 1904: 'I recollect the western prairie grouse in this part of the country. I saw one once in Newton; and once after I was married, your father went down to the cape fishing, and in the woods there I saw a grouse very near me and saw him puff up that orange they have on the side of the neck.' Eliza Cabot was born on April I7, I79I, and married about I8II. Her granddaughter, Mrs. Charles Almy, thinks it probable that she saw the grouse in Newton about the beginning of the nineteenth century, and the one on the 'cape' (Cape Cod, no doubt) about $\mathrm{I} 8 \mathrm{I} 2$. That both birds were heath hens can scarcely be doubted, for there is no evidence 
that living western grouse of any kind were introduced into Massachusetts at so early a period."

From the evidence given by Mr. Brewster and other writers it may be assumed that the heath hen was more or less abundant on the site of Boston at the time that city was founded, and there is no reason why it should not have been numerous in other favorable situations along the New England coast and to the southward. Early writings tell us that it was so. It was found along the seaboard south of New Jersey, and the late C. S. Wescott, of Philadelphia, frequently spoke of it as having occurred-according to tradition -in Maryland and Delaware, on the shores of the Chesapeake Bay and on the Peninsula of Maryland and Virginia.

Nuttall, as late as 1832 , says of the heath hen: "Along the Atlantic coast they are still met with on the grouse plains of New Jersey, on the brushy plains of Long Island, in similar shrubby barrens in Westford, Conn., in the islands of Martha's Vineyard on the south side of Massachusetts Bay, and formerly, as probably in many other tracts, according to the information which I have received from Lieut.Governor Winthrop, they were so common on the ancient bushy site of the city of Boston that laboring people or servants stipulated with their employers not to have the heath hen brought to table oftener than a few times in a week!"

Linsley, in his list of Connecticut birds, eleven years 
later than Nuttall, speaks of the birds as already extinct in that State.

Giraud, writing about I840, says that even then the bird was practically extinct on Long Island, but that it had been abundant thirty years before.

Audubon quotes an interesting letter from a Mr. David Eckley, of Boston, who was in the habit of shooting prairie hens on Martha's Vineyard. This letter declares that "Nashawenna is the only other island of the group on which they are found," and further along adds: "It would be difficult to assign a reason why they are found upon the islands above named, and not upon others, particularly Nashann, which, being large, well wooded, and abounding in feed, seems quite as favorable to the peculiar habits of the birds."

Even at that time, according to this letter, the heath hens on Martha's Vineyard were scarce, for Mr. Eckley says that the result of a few weeks' residence of a party of three is ten brace of birds.

The same gentleman says: "We frequently meet with the remains of such as have been destroyed in various ways, but more particularly by the domestic cat, which prowls the woods in a wild state, and which often receives a very unwelcome salute for the mischief it does. Owls, hawks and skunks also do their part toward the destruction of these valuable but defenceless birds. In these ways they are thinned off much more effectually than by the sportsman's gun. They frequent no particular soil, and, like all other hunting, 
wherever the food is, there is the likeliest place for the game. In addition to this rule as a guide, we look for their fresh tracks among the sandy barberry hillocks and along the numerous patches which intersect that remarkable part of the Vineyard called Tisbury Plain. Into this, should the birds fly from the hedges, as they sometimes do, it is almost impossible to start them a second time, as there are no trees or large objects to mark their flight. Being mostly covered with scrub oak of a uniform height, with occasional mossy hollows, it affords them a place of refuge, into which they fly for protection, but from which they soon emerge, when the danger is passed, to their more favourite haunts."

This letter was written in December, I832.

The ornithologists of the first half of the nineteenth century did not differentiate the pinnated grouse of the Mississippi Valley from the eastern bird, and spoke of the pinnated grouse as even then almost exterminated from its old range on the Atlantic coast. A contemporary statement of interest as to the heath hen is that made by Elisha J. Lewis in "The American Sportsman," published in Pennsylvania, I857. He says:

"The prairie hen was, no doubt, at one time widely disseminated over our whole country, more particularly in those portions interspersed with dry, open plains strrounded by thin shrubbery or scantily covered with trees. Unlike the ruffed grouse, this bird delights in the clear, open prairie grounds, and will desert those districts entirely which in the lapse of time become 
covered with forest. These birds are very rarein fact, may almost be considered extinct in the Northern and Middle States. Within a few years they were quite abundant on some portions of Long Island. They were also to be found in Burlington County, N. J., and in some few other places. There are, however, still a few to be found on the Jersey plains, and every season we hear of some of our sporting acquaintances exterminating a small pack. We know of ten braces being killed this season (I848), and about the same number last year by the same party; and, as usual, in both instances these scarce and beautiful birds were butchered long before the time sanctioned by the strong -or, rather, the weak-arm of the law.

"Thus it is that the destructive hand of the wouldbe respectable poacher, as well as the greedy gun of the pothunter, hastens to seal the fate of the doomed prairie hen in these eastern regions, and we may predict with great certainty that ere long not one will be found, save upon the rich plains of the West; from which also, in course of time, they will be driven and ultimately perish, root and branch, from before the unerring guns of their ruthless destroyers. We understand that there are still a few of these birds to be found in Pennsylvania-we believe in Northampton County - where the pine forests are thin and open and the country about them such as prairie hens delight in. They have always been abundant in the barrens of Kentucky and Tennessee, as also in the balmy plains and fertile prairies of Louisiana, Indiana and Illinois. 
So numerous were they a short time since in the barrens of Kentucky, and so contemptible were they as game birds, that few huntsmen would deign to waste powder and shot on them. In fact, they were held in pretty much the same estimation, or, rather, abhorrence, that the crows are now in Pennsylvania or other of the Middle and Southern States, as they perpetrated quite as much mischief upon the tender buds and fruits of the orchards, as well as the grain in the fields, and were often so destructive to the crops, that it was absolutely necessary for the farmers to employ their young negroes to drive them away by shooting off guns and springing loud rattles all around the plantations from morning till night. As for eating them, such a thing was hardly dreamed of, the negroes themselves preferring the coarsest food to this now much admired bird; while the young sportsman exercised his skill in rifle shooting upon them, in anticipation of more exciting sport among the other prized denizens of the plains and forest. Prairie chickens have not only deserted Long Island, Martha's Vineyard, Elizabeth Island, New Jersey, and their other haunts to the eastward, but they have also removed even farther west than the barrens of Kentucky. . . ."

Lewis says also in the course of this article that the pinnated grouse are easily domesticated, and will pair and hatch in captivity-all this from Audubon.

The species has been extinct for more than forty years in New Jersey and Pennsylvania. Mr. Witmer Stone says that up to I868, and probably later, 
a few were said to occur on the barren plains which cover portions of Ocean and Burlington counties in New Jersey. This is a part of the pine barren region, an elevated, dry tract covered with dwarf pines, which average not more than a foot and a half in height. Turnbull, in his "Birds of Eastern Pennsylvania," states that in I869 a few survived in Monroe and Northampton counties in that State.

The heath hen is very similar to the prairie hen, but slightly smaller. The tufts of pointed neck feathers are shorter and, as already said, the bird has slight points of difference in color. Though called a woodland bird, it is much in the open or in the thick, low scrub oak and pines which cover an area of forty miles square. There are thought to be not more than I50 or 200 of these birds left alive, and they are therefore more nearly extinct than the buffalo. They are already protected by law and should be still more strongly protected by public opinion of the residents of Martha's Vineyard, who ought to feel proud of this bird and to do everything in their power to preserve it.

Not much had been written about the heath hen on Martha's Vineyard until the year I885, when Mr. William Brewster visited the island for the special purpose of studying the bird. He reported the results of this visit in the $A u k$, and in I8go repeated the trip and gained additional information, which was printed in Forest and Stream. He said :

"Throughout Martha's Vineyard, the heath hen 
(locally pronounced hêth'n, as this grouse is universally called) is well known to almost every one. Even in such seaport towns as Cottage City and Edgarstown, most of the people have at least heard of it, and in the thinly settled interior it is frequently seen in the roads or along the edges of the cover by the farmers, or started in the depths of the woods by the hounds of the rabbit and fox hunters.

"Its range extends, practically, over the entire wooded portion of the island, but the bird is not found regularly or at all numerously outside an area of about forty square miles. This area comprises most of the elevated central portions of the island, although it also touches the sea at not a few points on the north and south shores. In places it rolls into great rounded hills and long, irregular ridges, over which are scattered stretches of second-growth woods, often miles in extent, and composed chiefly of scarlet, black, white and post oaks, from fifteen to forty feet in height. Here and there, where the valleys spread out broad and level, are fields which were cleared by the early settlers more than a hundred years ago, and which still retain sufficient fertility to yield very good crops of English hay, corn, potatoes and other vegetables. Again, this undulating surface gives way to wide, level, sandy plains, covered with a growth of bear, chinquapin and post-oak scrub, from knee to waist high, so stiff and matted as to be almost impenetrable; or to rocky pastures, dotted with thickets of sweet fern, bay- 
berry, huckleberry, dwarf sumac and other low-growing shrubs.

"Clear, rapid trout brooks wind their way to the sea through open meadows, or long, narrow swamps, wooded with red maples, black alders, high huckleberry bushes, andromeda and poison dogwood, and overrun with tangled skeins of green briars.

"At all seasons the heath hens live almost exclusively in the oak woods, where the acorns furnish them abundant food, although, like our ruffed grouse, they occasionally at early morning and just after sunset venture out a little way in the open to pick up scattered grains of corn or to pluck a few clover leaves, of which they are extremely fond. They also wander to some extent over the scrub-oak plains, especially when blueberries are ripe and abundant. In winter, during longcontinued snows, they sometimes approach buildings, to feed upon the grain which the farmers throw out to them. A man living near West Tisbury told me that last winter a flock visited his barn at about the same hour each day. One cold, snowy morning he counted sixteen perched in a row on the top rail of a fence near the barnyard. It is unusual to see so many together now, the number in a covey rarely exceeding six or eight, but in former times packs containing from one to two hundred birds each were occasionally met with late in the autumn.

"Only one person of the many whom I questioned on the subject had ever seen a heath hen's nest. It was in oak woods, among sprouts at the base of a large 
stump, and contained either twelve or thirteen eggs. The date, he thought, was about June Io. This seemed late, but I have a set of six eggs taken on the Vineyard July 24, I 885, and on July I9, I890, I met a blueberry picker who only the day before had started a brood of six young, less than half grown. These facts prove that this bird is habitually a late breeder.

"The farmers about Tisbury say that in spring the male heath hen makes a booming or tooting noise. This, according to their descriptions, must resemble the love notes of the western pinnated grouse. About sunrise, on warm, still mornings in May, several birds may be sometimes heard at once, apparently answering one another.

"During my stay at Martha's Vineyard, I obtained as many estimates as possible of the number of heath hens which are believed to exist there at the present time. My most trustworthy informants were, creditably, averse to what was apparently mere ille guessing; but when I questioned them, first as to the extent of the region over which the birds ranged, and next as to how many on the average could be found in a square mile within this region, they answered readily enough, and even with some positiveness. As already stated, the total present range of the heath hen covers about forty square miles. The estimates of the average number of birds per mile varied from three to five, giving from $\mathrm{I} 20$ to 200 birds for the total number. These estimates, it should be stated, relate to the number of birds believed to have been left over from last 
winter. If these breed freely and at all successfully, there should be a total of fully 500, young and old together, at the beginning of the present autumn. When one considers the limited area to which these birds are confined, it is evident that within this area they must be reasonably abundant. I was assured that with the aid of a good dog it was not at all difficult to start twenty-five or thirty in a day, and on one occasion eight were killed by two guns. This, however, can be done only by those familiar with the country and the habits of the birds."

The fact that but a small remnant was left of this once widely distributed species aroused much interest in it, and after a time the Massachusetts authorities began to consider measures for its preservation. Before any steps looking to its preservation had been taken, the numbers of the birds had still further diminished, and observations made on the island from October, I906, to May, I907, at a time when they were collected in large flocks, seemed to justify the conclusion that the number of individuals was less than one hundred.

The report of the commissioners on fisheries and game for the year ending December 31, I907, declares that by actual count of the flocks located in various sections of the range, seventy-seven individuals were enumerated. In May, I906, a destructive forest fire swept practically the entire breeding grounds, and very few birds were reared that season. The summer of 1907, however, was a favorable one. At least ten 


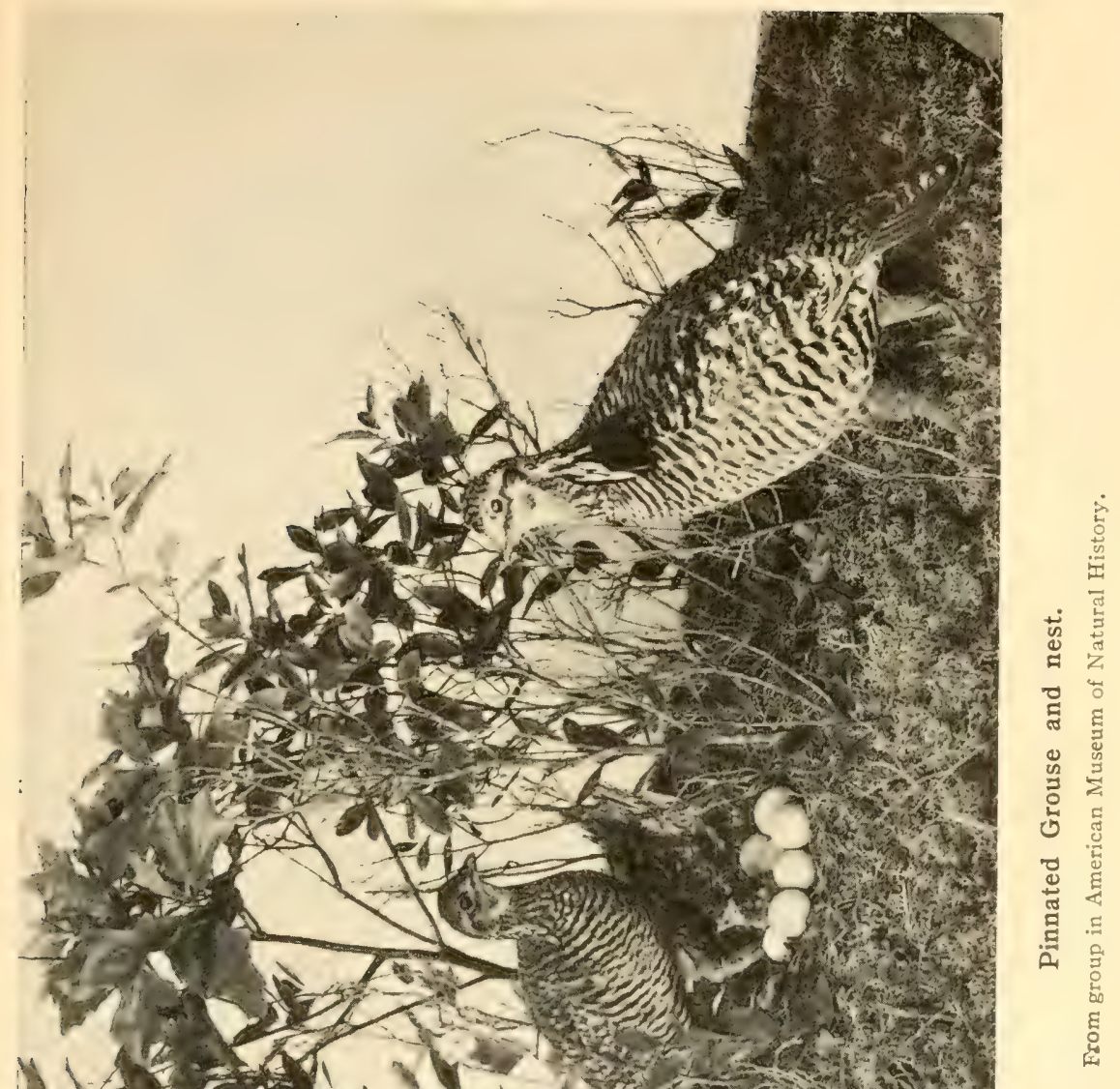



broods were successfully reared, and it was believed that the number had more than doubled.

The first protective law relating to the heath hen is said to have been passed in I83I. This provided for a closed season from March I to September $x$. In 1837 there was established a closed season of four years, which in the same year was extended for five years more. These Acts, however, permitted any town to suspend the law, so far as that town was concerned, for such a period as might be deemed expedient, and in 1842 the town of Tisbury did suspend the law for a period of ten days on more than one occasion. In fact, the law in behalf of these birds fell into clesuetude and no effort was made to enforce it up to about I905. The inhabitants of Martha's Vineyard felt a local pride in having there a bird found nowhere else in the world, but this local pride was not strong enough to protect the species.

An observer who visited the island in the spring of I906 made to the commissioners on fisheries and game of Massachusetts a report which gives much interesting detail as to the habits of the heath hen at the particular time when they are preparing to mate, and is well worth quoting in full. He says :

"At 6 P.M. we arrived at the point where we hoped to find traces of the heath hen. In a cleared field, about thirty rods from the road, we distinctly saw two large birds. On our nearer approach they squatted close and their protective coloration was so effective that although we knew almost exactly the precise location 
of the birds, we could not distinguish them. We crawled behind the nearest cover and remained motionless for perhaps ten minutes. At length the long shadows from the descending sun enabled us to distinguish the birds as they crouched with head close to the ground among the very scanty vegetation. After another interval of motionless activity on our part, one bird quickly arose and began feeding, apparently without suspicion; soon two more birds arose as if by magic from the ground. Then began a most interesting series of antics. These birds were joined by five others, coming in singly and on foot from the scrub in various directions. The birds came frequently within forty paces of our hiding place, and in one instance alighted on a small oak tree twenty-three paces from our camera. While not near enough for successful photographing, we were well situated for using our field-glasses. The birds were all actively feeding in the open field, apparently on grasshoppers and other insects, but nipping red clover leaves very freely. They moved leisurely about. Frequently two birds, sometimes as much as a hundred to a hundred and fifty yards apart, ran directly toward each other, dancing and blowing on the way, with the so-called 'neck wings' pointed upward in a $\mathrm{V}$ form. On facing each other, both squatted and remained motionless from one to five minutes. We could see none of the nodding and pecking motions of the head so commonly indulged in by domestic fowls when fighting; rarely was there sparring with the bill, or striking with the feet or 
wings. In twelve or fifteen encounters, only three or four times did they strike thus, and only once did we see 'feathers fly.' Most of the energy seems to be spent in posturing and blowing. Generally, one of the combatants backs slowly away, suddenly stopping if the opponent advances too rapidly. In all these fighting tactics the similarity of habits with those of the domestic fowl were very marked. From all directions came the peculiar toot, like distant tugboats in a fog, all having whistles of the same pitch. This call may be well imitated by blowing gently into the neck of a two-drachm homeopathic vial. Each call extends over a period of two seconds, and is repeated at frequent intervals. It is prefaced by a run of about one yard, with very rapid, mincing steps. The strides, however, are so short that the bird does not advance rapidly. The tail is spread and the wings dropped after the manner of the strutting turkey-cock. When the tail is spread, the white under-tail coverts are conspicuous and remind one forcibly of the 'white flag' of the deer and antelope, or of our gray rabbit. The head is then depressed and the neck outstretched forward, until it is parallel with the surface of the ground; the neck tufts are elevated to a $V$ shape. The bright, orangecolored air-sacs on each side of the neck, directly behind the tufts of feathers, are slowly inflated until they reach apparently the size of a tennis ball, when they appear like two small ripe oranges, one protruding from either side of the neck. The duration of the call appears to closely coincide with the period of infla- 
tion, and seems to be emitted as the air enters the sac, rather than when the air is expelled. The collapse of the sac is sudden. The sound is ventriloquial, and it is very difficult to locate the direction or distance whence it comes, unless the bird can be seen. A second sort of call is much less frequent and closely resembles a single syllable of the hoot of the barred owl.

"Another characteristic antic was a peculiar combination of a short run, a sudden jump of three to five feet into the air, and a rapid uncoördinated flop and scramble in the air, the bird usually alighting within ten or twenty feet of the starting point, but turning so as to face at least at right angles, or even in the opposite direction from which it started. When in the air it emits a peculiar cacophonous call or cackle, which, when heard at a distance, gives the impression of a hearty burst of laughter. The purpose of these semi-somersault-like maneuvers appeared to be to attract the attention of other birds, possibly even as a challenge, for frequently they seemed to precede the somewhat pacific duels described above. The effect of these sounds, together with the tooting calls, in the mists which so often obtain in their habitat before sunrise, is weird in the extreme. At 4:15 A.M., on May 2, these sounds were practically continuous, without appreciable interval, apparently from all directions. At 4:45 A.M. six birds could be counted, all in sight at once. They appeared to resort to a particular, clear space, of about two acres in extent, where the antics just described were carried on. All the birds, except 
one, were observed to have the orange-colored airsacs. These were probably cocks. We saw only one bird which we suspected might be a hen. The other hens were probably nesting, or at least had secured mates, and no longer resorted to the promenading place. As the sun rose high the tooting became less frequent; the birds became more restless, often flying to the neighboring low oaks, resting there until disturbed."

William Hazen Gates, of Williamstown, Mass., worked that spring with the Massachusetts commissioners, studying the habits of the heath hen, in order to secure information which might be of use in artificially propagating the species. He says:

"On May 3I, while wandering across the plains, three heath hens were started, and each taking wing flew nearly out of sight before alighting. As I watched the birds, a call, resembling to a slight degree that of an ordinary barnyard cock calling to the hens, was heard not far distant. The place was noted as nearly as possible, and then cautiously I made my way there. When the place was reached I looked for birds, but could see none. I then sat down and determined to wait, in order to see if any birds could be heard. The ground was covered with leaves, so the least stir would have been heard. I listened and also looked for signs of anything moving, but none appeared. I sat there for fully twenty minutes and, hearing nothing, concluded that either there were no birds or else they had gone as I approached. As I rose a bird flew up within 
twenty feet of where I had been watching. The bird had been within sight all the while, but probably had crouched in the leaves and remained invisible. It would have been interesting to note how much longer the bird would have stayed in this position without moving. Another bird was started some fifty feet from this one.

"On this same day the toots of one or more heath hens were heard between half-past four and five A.M. The birds are early risers and late bed-goers. Once they were heard to toot at 3:30 A.M., or about an hour before sunrise; and several times their call note was heard as early as this. It is probable, though, that they do not begin to stir quite so early, beginning their breakfasting about sunrise or a little earlier. The middle of the day is generally spent in the shade, or in dusting in the sun in the roads. Late in the afternoon, as the air begins to cool, they take to feeding again, and can be seen in the open fields. They will often feed till nearly an hour after sundown. I do not know whether they roost in the low shrubbery or on the ground at night. Mother birds with young, however, stay on the ground, but it is likely that this is done only while the young are too small to roost and need the shelter of the mother.

"On June 29 a bevy of heath hens was found. The mother bird took flight, cackling, and flew some fifty feet or so. The young scudded in every direction, and were entirely out of sight by the time I reached the spot. I hunted around through the leaves some, but 
fearing that I might accidentally step on one, did not search very carefully, and so did not see any. Two days later, what I think must have been the same bevy was again seen, but about half a mile from the place where they were first seen. This time they were in a more or less cleared space, and six of the young were counted. One or two squatted just where they were, and it looked as if one might go right up to them and pick them up. I did not, however, disturb them. These birds were apparently not over a week old.

"On July 2 a mother heath hen and four young were seen dusting in a road about I I A.M. Upon seeing me the mother ran to the bushes and called to the young. As I went by I could hear the mother hen at the side of the road in the bushes. The same day in the afternoon, a mother hen and one young bird were seen.

"On July 7, while walking through the brush near the Cromwell cottage, soon after sundown, I heard some peeping ahead. Getting on my hands and knees, I crawled toward the sound. The pecping continued as I approached, so I knew that I had not been perceived. Finally, at a distance of some twenty or twenty-five feet, I saw a mother hen with wings spread under the thick foliage of a stunted oak. She was more or less silent, only occasionally uttering a low call, somewhat resembling that of a hen as she calls her chicks at night under her wings. The young, however, peeped quite often as they stole in and out from under the wings of the mother. I think they could not have been much more than a day or two old. 
Like the chicks of other fowls, they could not seem to get settled for the night, but would stray in and out. Then as they sought a place of shelter again they would shove one of their fellows out from under the mother's wing. However, as darkness grew the restlessness ceased, and by the time it was too dark to see the group everything was silent. How many there were in the bevy I could not tell, but it seemed that there must have been at least six or eight."

Though the number of these birds is so pitifully small, yet, as already suggested, they pack in the same way as does the western pinnated grouse. The report of the Massachusetts commissioners on fisheries and game for I907 states that on January I I, I908, a flock was counted which contained not less than fifty-five nor more than sixty birds. The same report declares that the birds remained in these flocks until late in February and began to utter their calls on the approach of warm weather, and when this takes place the flocks break up and the season for mating begins. The elaborate performances earlier described begin about April $\mathrm{I}$, and end about the middle of June, being at their greatest height the last of April and early part of May. The chicks are hatched in June and in July. When about the size of quails they make long flights when alarmed.

Among experiments carried on by the Massachusetts commission was the taking of a set of nine heath hen eggs, which were placed under a bantam hen. Only one of these eggs hatched, and the chick was at once 
killed by the hen. The hen was subsequently given some pheasant eggs, and hatched them and reared the chicks with all possible care.

That this bird possesses a high interest, not only for the sportsman, but because it is now on the very point of extinction, is obvious. Much has been said and written about its preservation, but the credit for setting on foot a movement which it is hoped may prevent the extermination of the species is due to Mr. J. E. Howland. He urged the importance of the situation on the Massachusetts commission, and a permanent guardian was located in the region inhabited by the birds to study their habits and enforce the law. Somewhat later, Representative Mayhew introduced a bill into the General Court, placing under the use and control of the commission such lands as may be donated, leased, purchased or otherwise placed under temporary or permanent control, as a refuge and breeding area for the heath hen. A number of individuals have subscribed money to enable the commission to take advantage of this law, and about sixteen hundred acres have been placed under special protection. The Massachusetts legislature has authorized the commissioners to take such unimproved lands upon Martha's Vineyard-not exceeding one thousand acres-as they may deem necessary for the purpose of making fire stops for the protection from fire of the feeding and breeding grounds of the pinnated grouse, or of otherwise securing the maintenance and increase of such pinnated grouse or of any other species of wild birds upon said 
islands. Two thousand dollars was appropriated for work incidental to these purposes and for an investigation and reports upon the best methods and possible cost of protecting and increasing the colonies of birds on the island. This appropriation, and the authority to take the land, ought to protect the heath hen from a danger which has been of late years the most important element in reducing its numbers-the bush and forest fires. The pinnated grouse of the West have suffered from the same cause.

An investigation by the commissioners on fisheries and game of the problems involved in the preservation of the heath hen leads them to believe that one or more extensive areas, whether they be called reserves, sanctuaries or refuges, should be acquired by the commonwealth and patrolled and maintained. Such refuges should include the chief breeding and feeding grounds of the birds, and on the land should be sown crops of clover and such cultivated grains as they delight to feed on; that suitable fire stops or breaks should be maintained in order to reduce the danger of bush fires, so destructive to the birds in the past; that every precaution should be taken against the contagious diseases which might be transmitted to these wild birds through domestic fowls; that as soon as the number of birds is sufficiently increased, systematic artificial incubation, feeding and breeding should be begun for the purpose of rearing annually an increased number of birds. The commissioners believe that by artificial propagation the number of eggs laid may be increased, while it is 
obvious that this means will lessen the loss resulting from the destruction of nests, eggs and young birds by natural enemies, whether mammals or birds. They believe that the expenditure involved would be practically that incidental to ordinary poultry raising, except that on account of the hardiness and vigor of the grouse it would need little or no winter shelter.

The commissioners, in their report for the year I907, report contributions from private individuals of not less than $\$ 2,420$ for the purpose of preserving these birds. Of this sum, the town of Tisbury and the Middlesex Sportsmen's Association made the largest contributions of $\$ 200$ each, but there are a large number of subscribers, and the list ought to be largely added to, since every sportsman and every naturalist in the land should be ambitious to have some share in the good work of re-establishing this splendid bird.

THE PRAIRIE HEN.

This is the form of pinnated grouse that has been known to sportsmen. Its range was chiefly in the Mississippi Valley, including Minnesota, Michigan, western Ohio, Kentucky, but perhaps not Tennessee, though it was found in Louisiana, southern Texas, Indian Territory, Kansas, Nebraska and the eastern parts of both Dakotas. It is now found in Manitoba, southeastern Saskatchewan, to eastern Colorado, northeastern Texas, Arkansas, western Kentucky and Indiana and intermediate regions, where it was at one 
time enormously abundant, and, being exceedingly tame at certain seasons of the year, was very readily destroyed.

Throughout almost all this region the bird was resident, though in the northern portion it regularly made seasonal changes of location, which, though commonly called migratory, hardly deserve to be so characterized. On this point Mr. W. W. Cooke, in his report on "Bird Migration in the Mississippi Valley," says:

"The prairie chicken is commonly said to be a resident bird, and so it is in a larger part of this range, but in Iowa a regular though local migration takes place. This has been mentioned by former writers, and in the spring of I884 a special study was made of the matter. Many observers unite in testifying to the facts in the case, and, what is still more important, there is not a dissenting voice. One of the observers does not exaggerate when he says: 'Prairie chickens migrate as regularly as the Canada goose.' Summing up all the information received, the facts of the case are as follows: In November and December large flocks of prairie chickens come from northern Iowa and southern Minnesota to settle for the winter in northern Missouri and southern Iowa. This migration varies in bulk with the severity of the winter.

"During an early cold snap immense flocks come from the northern prairies to southern Iowa, while in mild, open winters the migration is much less pronounced. During a cold, wet spring the northward movement in March and April is largely arrested on 
the arrival of the flocks in northern Iowa, but an early spring with fair weather finds them abundant in the southern tiers of counties in Minnesota, and many flocks pass still farther north. The most remarkable feature of this movement is found in the sex of the migrants. It is the females that migrate, leaving the males to brave the winter's cold. Mr. Miller, of Heron Lake, Minn., fairly states the case when he says: "The females in this latitude migrate south in the fall and come back in the spring, about one or two days after the first ducks; and they keep coming in flocks of from ten to thirty for about three days, all flying north. The grouse that stayed all winter are males.' "'

Audubon noticed and spoke of these movements nearly a hundred years ago, for in his account of this species he says:

"During the first years of my residence at Henderson $\left(K_{y}.\right)$, in severe winters, the number of grouse of this species was greatly augmented by large flocks of them that evidently came from Indiana, Illinois and even from the western side of the Mississippi. They retired at the approach of spring."

When John James Audubon first lived in Kentucky, the "Barrens"-by which is meant open stretches of land without timber-swarmed with these birds, and they were looked on more or less as a pest. They were credited with committing much mischief among the fruit trees of the orchards in winter, and in the spring they fed on the grain in the new-sown fields. They 
were so abundant as to be caught in pens and traps, and any one could kill as many as he wished. Indeed, Audubon speaks of a friend who was fond of practicing rifle shooting, who killed upward of forty in one morning and did not pick them up.

Twenty-five years later Audubon speaks of them as at that time not being found in any numbers east of the State of Illinois, and says that there, too, they are decreasing at a rapid rate.

At the approach of spring the large packs, which have held together during the winter, break up into smaller companies of from twenty to fifty, and before long-in March or April-the mating begins. This has been spoken of by many writers as the booming of the prairie chicken, or the dance of the prairie hen, though this last term is more commonly applied to the spring maneuvers of the sharp-tailed grouse. This mating has been described in a somewhat spectacular manner by Audubon, but recent observers have not seen such fierce encounters as he describes. An excellent account of this mating play was printed in Forest and Stream many years ago by Judge John Dean Caton, an early settler of Illinois, who had been familiar with these birds for almost all his life. He says:

"The spring of the year is the season of courtship with them, and it does not last all the year round, as it does with humans, and they do it in rather a loud way, too; and instead of taking the evening, as many people are inclined to do, they choose the early morning. Early in the morning you may see them assemble 
in parties, from a dozen to fifty together, on some high, dry knolls, where the grass is short, and their goings on would make you laugh. The cock birds have a loose patch of naked yellow skin on each side of their neck just below the head, and above these on either side, just where the head joins the neck, are a few long black feathers, which ordinarily lie back on the neck, but which, when excited, they can pitch straight forward. These yellow naked patches on either side of the neck cover sacs which they can blow up like a bladder whenever they choose. These are their ornaments, which they display to the best advantage before the gentler sex at these love feasts. This they do by blowing up these air-sacs till they look like two ripe oranges, on each side of the neck, projecting their long, black ears right forward, ruffling up all the feathers of the body till they stand out straight, and dropping their wings to the ground like a turkey cock. Now they look just lovely, as the coy, timid maidens seem to say, as they cast side glances at them, full of admiration and love.

"Then it is that the proud cock, in order to complete his triumph, will rush forward at his best speed for two or three rods through the midst of the lovesick damsels, pouring out as he goes a booming noise, almost a hoarse roar, only more subdued, which may be heard for at least two miles in the still morning air. This heavy booming sound is by no means harsh or unpleasant; on the contrary, it is soft and even harmonious. When standing in the open prairie at eariy 
dawn, listening to hundreds of different voices, pitched on different keys, coming from every direction and from various distances, the listener is rather soothed than excited. If this sound is heavier than the deep keynotes of a large organ, it is much softer, though vastly more powerful, and may be heard at a much greater distance. One who has heard such a concert can never after mistake or forget it.

"Every few minutes this display is repeated. I have seen not only one, but more than twenty cocks going through this funny operation at once, but then they seem careful not to run against each other, for they have not yet got to the fighting point. After a little while the lady birds begin to show an interest in the proceedings by moving about quickly, a few yards at a time, and then standing still a short time. When these actions are continued by a large number of birds at a time, it presents a funny sight, and you can easily think they are moving to the measure of music.

"The party breaks up when the sun is half an hour high, to be repeated the next morning and every morning for a week or two before all make satisfactory matches. It is toward the latter part of the love season that the fighting takes place among the cocks, probably by two who have fallen in love with the same sweetheart, whose modesty prevents her from selecting between them."

Audubon reports that he tried the experiment of puncturing the inflatable air-sacs on the neck of a male prairie chicken. He caught one of the birds and passed 
the point of a pin through each sac, and found that thereafter it was unable to toot. He performed this same experiment with another bird on one side only, and found that the next morning it uttered the tooting sound with the uninjured air-sac, but could not inflate the one that had been punctured. He states that his efforts to decoy this species by imitating its curious sounds were unsuccessful, "although the ruffed grouse is easily deceived in this manner."

After the close of the mating operations the locations of the nests are selected. Often they may be in hedges and the margins of clumps of underbrush, in fence corners or along the borders of sloughs, but often, again, in the middle of a field amid the tall grass. The eggs number from eleven to fourteen, and sets of twenty or even twenty-one eggs are not unknown. They vary in color from cream to light olive or pale brown, and are often regularly spotted with fine pin-points of reddish brown. Captain Bendire regards the prairie chicken as one of the most prolific of our game birds.

Now, however, comes the season of danger; the eggs have been deposited in a slight depression, scratched out among the weeds or grass, and the hen begins to brood. If she has nested early and the season is late, the streams may rise and flood her nest and destroy the eggs or drown the tiny young, if they have already hatched; or early prairie fires, burning among the dead grass and weeds of the preceding season, may destroy mother and clutch alike; or, later still, the mowing machine may kill the mother or the young, too smali 
to fly and too inexperienced to force themselves through the thick grass away from the approaching danger. In old times it used to be said that in wet seasons thonsands and thousands of prairie chickens' nests were ploughed under when the fields were being prepared for grain. Certain it is that the combination of all these dangers, together with the insatiate gunner, at one time came very near exterminating the pinnated grouse from the States of Illinois and Indiana.

If the mother bird is fortunate enough to bring off her young, she leads them about much as do other grouse, to the best feeding grounds. She is watchful of danger for them, and at her warning cry the young squat on the ground, which they so closely resemble that it is almost impossible to find one of them. The mother uses every art to lead the intruder away from the brood. The birds grow rapidly, and by the middle of August-the date at which up to within a few years it has been legal to shoot them-are nearly two-thirds grown. They are then very easily killed, and the sport becomes mere butchery. When cold weather approaches, however, they grow stronger of wing, and soon after this pack.

Audubon was perhaps the first to announce that the pinnated grouse is easily tamed and easily kept. He declares also that they breed in confinement. A number that he had while at Henderson were turned loose in his garden and orchard, and within a week became so tame as to allow him to approach them. They readily ate corn and vegetables, became so gentle 
during the winter as to feed from the hand of his wife, and altogether acted as domestic poultry might act. In spring they went through the operations of mating just as did their wild brethren, and a number of them hatched, but at last the birds proved so destructive in the garden that they were ordered to be killed.

As will be seen on another page, birds sent to England became quite tame, and many years ago I had a dozen of these grouse in New York, which, when turned out in the spring, so readily accustomed themselves to their surroundings that they followed a man who was spading the garden and scratched and crowded over the freshly turned-up earth in search of insects. They were less wild than so many domestic hens.

In many of its ways, the pinnated grouse suggests a domestic fowl. Though often carrying its tail drooping toward the ground, it often carries it upright, as a hen carries her tail. The mother of a young brood will fight for it, or at least will try to frighten away an intruder. The young chicks constantly talk to each other as they move along, and if one of them discovers an insect and runs after it all those within sight join in the pursuit.

Mr. E. E. Thompson, in his "Birds of Manitoba," points out that, while it was only in I 88 I or I 882 that the pinnated grouse was found in Manitoba, before I890 it had become common at many points, such as Winnipeg, Portage la Prairie and other localities. Previous to this, in 1872 , Dr. Cones had written: 
"I have no reason to believe that it occurs at all in northwestern Minnesota' or North Dakota."

In Manitoba they seem more or less to associate with the sharp-tailed grouse, so much so that sometimes birds of both species will be started from before the dog. When winter comes, however, and the sharp-tailed grouse go into the woods, the pinnated grouse stay out on the prairie.

\section{LESSER PRAIRIE HEN.}

The range of the lesser prairie hen has already been given.

While riding over the prairie through the western part of the Indian Territory in the month of March, I have more than once driven for hours through flocks of these birds, contentedly feeding on the prairie and wholly disregarding the wagon, which passed close to them. On these occasions we must have seen many thousands of the birds, and it is probable that immediately after this the packs broke up and the mating season began.

The pursuit of this form differs in no respect from that of its slightly larger relative to the North and East.

The most southern range in Texas of Attwater's prairie hens is given as just north of Fort Brown, near the coast, and it is very abundant south of San Antonio. 
THE PINNATED GROUSE TO-DAY.

An inquiry made in 1906 among the game commissioners of States where prairie chickens were formerly very abundant brought out a number of replies of great interest. Mr. E. E. Earle, then chief deputy warden of the State of Indiana, wrote to Forest and Stream as follows:

"Our supply of pinnated grouse decreased rapidly from year to year until г9ог. Prior to that time the open season had run from September I of any year to February I of the succeeding year. Under this law large numbers of these birds were slaughtered every year, they being young, not gun shy, and easily found.

"In Igor a law was passed prohibiting the killing of pinnated grouse, or possession of same, at any time between January I and November Io, and prohibiting export of such birds. Under the provisions of this act, which was rigorously enforced, pinnated grouse have increased in numbers, and may be found in great droves on our prairies and marshes.

"I was in Porter County last March, and one duck hunter told me of having seen in one flock what he estimated to have been one hundred prairie chickens, and such scenes are by no means rare. Wise laws and strict enforcement of same will increase them in any country that is suitable for their habitation."

Illinois, in the youth of men who are now elderly, was the great chicken ground of what used to be called 
the West, but the birds were so persecuted that a few years ago it was supposed that this grouse was nearly extinct there. Within the last few years, however, a great change is reported. State Game Commissioner John A. Wheeler wrote:

"My deputy game wardens throughout the State report prairie chickens, pinnated grouse, rapidly increasing. Our deputy wardens in Wayne County report 3,000 birds in that county by actual count. In Sangamon County, from personal observation and reports from the deputy wardens, I am convinced that we have nearly that many birds. From all over the State we are receiving encouraging reports of the increase of prairie chickens."

Almost the northwestern limit of the pinnated grouse's range is western Minnesota, and of this country Mr. S. F. Fullerton, then the executive agent of Minnesota's board of game and fish commissioners, reported interestingly. It is obvious that unless the cultivation of the land is such as to provide food for the pinnated grouse they will not do well there, and the character of Minnesota farming, which is largely dairying on small farms, is not such as to encourage occupancy by the pinnated grouse. In two letters, Mr. Fullerton said:

"The pinnated grouse, or prairie chicken, is disappearing from a large section of our State. It cannot stand civilization, but it is very odd that in new portions of the State that have been opened up they are 
very plentiful, and we have sections in Minnesota where the pinnated grouse are just as thick as they ever were.

"The State game warden of Manitoba states that their prairie chickens are not disappearing at all; in fact, they are increasing under rigid protection and stopping the sale. That is only across an imaginary line of Minnesota and Dakota, where these birds are plentiful, but in the southern part of our State, where dairying has taken the place of grain-raising, there are hardly any of the birds left. The sharp-tailed grouse, however, are different, as they are found in the brush country in great numbers where farms are opened up.

"A very pleasing thing happened to me last March. I was $u p$ in the northern part of the State, and in a drive of three hours I came across a stretch of land that had been cleared of jack pine. The clearing was several miles in extent, but it was surrounded by jack pine. The snow at the time was over two feet deep. The land last year was cultivated, some corn grown on it and some wheat and other coarse grain. In that clearing, the man with me and I counted over two hundred pinnated grouse. They appeared to have wintered finely and seemed in good condition."

When we reach Nebraska, we approach the limit of the pinnated grouse and enter the region of the sharptail just as we do in Minnesota. Both species were formerly abundant in Nebraska, but were so overshot by thoughtless gunners and by market shooters that they became rare. Mr. G. L. Carter, then chief warden 
of Nebraska's game and fish commission, wrote fully about birds in Nebraska :

"We have both the pinnated and sharp-tailed grouse, and we are so proud of them that it is a pleasure for me to tell you about them. The pinnated grouse are found more abundantly in the central and eastern parts of the State, while the sharp-tailed grouse are found in the northwest portion.

"A peculiar thing is that we seldom find a sharptailed grouse south of the Platte River; when we do, it is late in the season. The breeding and rearing grounds are principally in the northern and western sections, but a few are raised in other parts of the State.

"During the winter months, on account of scarcity of food in the north part of the State, which is principally grazing country, the birds are driven farther south, usually along the Platte River valley, sometimes going as far south as the northern counties of Kansas.

"A few days ago, while going from this city to Omaha, I saw a bunch of perhaps Ioo pinnated grouse within eight miles of the Omaha city limits. It is only through our effective game laws, passed during the winter of I90I, that we have these birds to any extent. Prior to that time they were being slaughtered by the market hunters from everywhere and shipped to the market. We were able to convince the Legislature of IgOI, that there had been shipped out of this State 235,000 of these birds during the year I9oo. We have had this shipping stopped, and, as a result, 
ranchmen and farmers throughout the State report birds more plentiful than at any time during the past fifteen years.

"If we take care of these birds, we will have them for a great many years to come, as we have boundless acres of territory which will never be cultivated, and which afford splendid breeding grounds for them."

Missouri is a State where in the past there have been many pinnated grouse, and from this State also we have a good report as to an abundant stock of birds which might easily be increased by proper care. State Game Warden J. H. Rodes' account of things will be read with interest:

"In twenty-five, if not more, of the II4 counties in this State, we have prairie chickens remaining in greater or less quantities. Originally, as you know, throughout the prairie districts of this State, these birds abounded in very liberal supply, but having had absolutely no protection up to and prior to the enactment of the present game and fish laws, which went into effect on June I5, I905, they were industriously hunted almost to the point of extermination, and were wholly killed off in many counties where they had formerly been found abundant.

"It was a common practice-notwithstanding we had a statute prohibiting it-to begin shooting these birds after July I, clear on and through the hunting season, when and wherever they could be found. Now that they are protected during the entire year, except from November I 5 to December ${ }_{15}$, we hope they will 
multiply and re-establish themselves in considerable number. To illustrate: This county, Pettis County, which is little larger, perhaps, than the average size county and fairly densely populated-Sedalia alone, the county seat, having a population of something over I5,000 inhabitants, and many more average-sized towns-has yet remaining in it, I would say, five or six hundred birds.

"Of course, it is difficult to estimate even approximately the number of birds remaining, yet it is no uncommon sight to see flocks of ten to twenty-five of these birds in the larger pastures and cornfields. A very reliable person told me the other day that he saw in the western part of our county a drove of about forty birds. Doubtless this was an accumulation of several flocks that were feeding together.

"While, as stated, this county is thickly populated, there yet remain many large pastures on which the virgin sod has never been broken, being used as pasture lands, and perhaps some as large as a thousand acres or more. They breed in these pastures and meadows and feed in adjacent oat and corn fields during the summer season. They were seen in unusually large numbers this winter, which I can but attribute to the fact that special effort was made to protect these birds during their breeding season last year.

"We were fortunate enough to secure one or two early convictions for hunting them out of season, and the gunners took alarm and very few were killed. What is true in this county, is true in many other coun- 
ties where like conditions exist. We intend to make these birds the object of special care and supervision in the hope that they may multiply and yet be seen in large quantities in this State. They should be protected during every month of the year for a period of five or six years, but the truth is that very few of the birds can be killed during the thirty days of the open season, as they are then full grown and are very strong, and will not lie before a dog and are very shy."

Kansas is another State where the prairie grouse was formerly abundant, but here the pinnated grouse is always the common bird, and the sharp-tail the exception. Mr. D. W. Travis, State fish and game warden, gave in brief but very telling form the history of the wholesale destruction and rapid decrease of prairie chickens until about ten years ago, and then of the change of sentiment and an increase of the birds during the year 1905. Mr. Travis says:

"Up to the year I885 pinnated grouse were very plentiful in Kansas and especially so in the western part. From that time they decreased very rapidly, until about 1900. Between those dates a grouse was seldom seen in the eastern half of the State, and but very few in the western half. The decrease was caused by the late burning of the prairies all over the western half of the State. Settlers were filling this section rapidly, and it seemed to be the general opinion that all dead grass should be burned, which destroyed all food and insects, starving the birds out and leaving no nest- 
ing grounds. Again, meat was scarce and high, and the settlers killed grouse the year round in order to supply their tables, and also killed thousands and sent them to eastern markets. This, with the hundreds of eastern market hunters, caused the almost complete extermination of the grouse in Kansas.

"About I900, the people began to realize that the grouse were nearly exterminated, and a crusade for their protection started. Stringent laws were passed in I903, and still more severe ones in 1905, and I am pleased to state that in the fall of 1905 in a number of the central counties the birds have increased to numbers beyond expectations, and to-day the grouse can be found in many of the eastern counties. With proper protection, pinnated grouse will be abundant in all parts of the State within five years. The day of the game butcher, the pot and market hunter is past."

Texas is now and always has been a State where pinnated grouse were abundant, and it is so large that there are still great numbers of birds there. The growth of the game protective sentiment, which has been so marked within the last year or two, promises to protect these birds.

There are other States, as Michigan and Wisconsin, that have a few pinnated grouse, and the bird occurs rarely in the Province of Ontario.

Prof. Walter B. Barrows, of the Michigan Agricultural College, whose writings on ornithological topics are familiar to many of our readers, says:

"This bird was formerly fairly common over the 
southern half of the Lower Peninsula, and up to twenty years ago was abundant in many places in the prairie regions of the three southernmost tiers of counties. Even ten years ago it was not uncommon in this county (Ingham), and undoubtedly a few still exist here. I am not able to say positively where it is most abundant now, but my latest reports, some two and three years ago, indicated that there were still a good many in Calhoun, Kalamazoo and Van Buren counties, and it is fair to presume that they were locally common in the three counties south of those and bordering Indiana.

"There are vague Michigan accounts of the presence of this species along the Lake Michigan shore as far north as Traverse City, fifty years ago, but I have no reason to believe that the species has ever been common north of the Saginaw Grand Valley in about latitude $432^{\mathrm{T}}$. The sharp-tailed grouse may at one time have existed in the upper part of the Lower Peninsula and in parts of the Upper Peninsula, but at present it is not known to occur except in Isle Royale in Lake Superior, where there appears to be a flourishing colony, but as yet $I$ have been unable to obtain specimens so as to determine positively the sub-species."

It would seem perfectly practicable to reintroduce this bird in eastern localities where once it was abundant, but this of course could be done only in situations where the bird would be sure to be protected; in other words, in large preserves. It is conceivable that the birds might live and do well on some of the large 
estates of Long Island, and even on the Shinnecock Hills, but it is hardly to be hoped that they could ever be brought back as a game bird. They would have to be regarded as merely beautiful natural objects. 


\section{SHARP-TAILED GROUSE.}

\section{Pediacetes phasianellus.}

Pediocetes phasianellus columbiamus.

Pediocetes phasiancllus campestris.

The sharp-tailed grouse, while about the same size as the pinnated grouse, is a somewhat plumper and stouter bird, and, from the fact that its tail is smaller, does not seem so large. The tail of the sharp-tail is graduated, the middle pair of feathers projecting much beyond the rest; it has no tufts of feathers on the side of the neck. It has a high crest, is brownish or rusty above, varied with spottings and barrings of black and darker brown. Large round white spots mark the wing coverts, and the scapulars are somewhat streaked with white, while the outer webs of the quills of the wing are spotted with white. The lower parts are for the most part white, varied with $\mathrm{V}$-shaped marks of dusky on front and sides of breast. The female is similar, but a little smaller. The differences between the three forms consist chiefly in the shades of colors.

The northern sharp-tailed grouse (Pedicocetes phasianellus-Linn.) is very dark-colored, with the dark markings on the upper parts very heavy, while the white marks on the wings show out strongly against this dark color. The feathering on the legs is dark 
brownish gray. In length it varies from about I9 inches for the largest males to about ${ }_{5} 5$ inches for the smallest females, and the wing measures from 8 to $8 \frac{1}{2}$ inches. Most of the tail feathers are extremely stiff, pointed and white-edged.

This northern bird is found in central Alaska, and

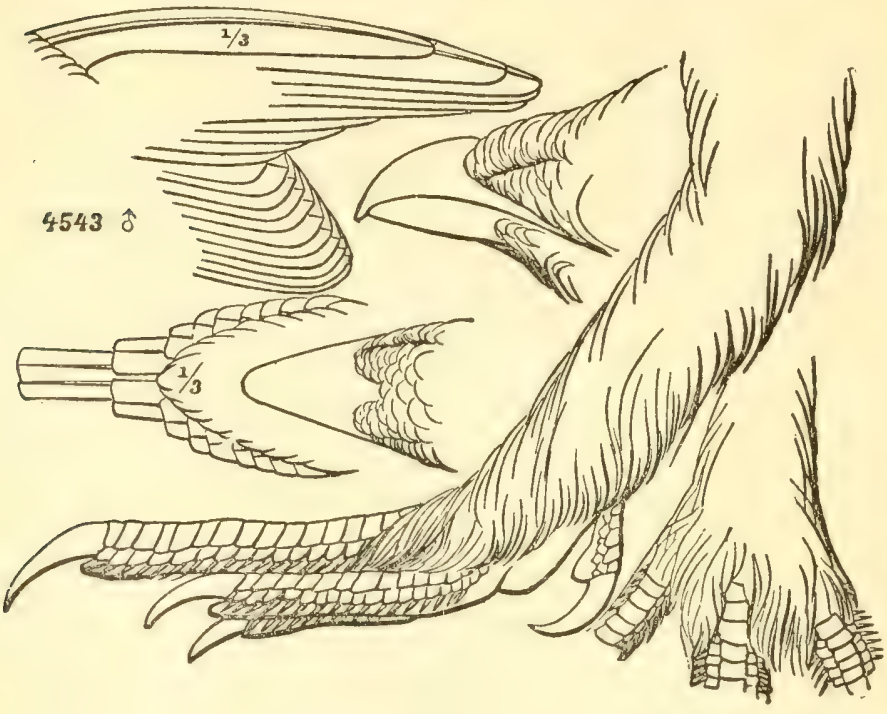

SHARPTAILED GROUSE

in the interior of British Provinces, north as far as Great Slave Lake, south as far as Moose Factory, Lake Winnipeg, Temiscaming, the northern shore of Lake Superior and the east side of James' Bay, in Labrador. It is never seen in the United States.

The western sharp-tailed grouse, or Columbian 
sharp-tailed grouse ( $P . p$. columbiamus) is very much paler in color, being grayish or clay color and marked with black, but with the black marks less sharp and strong. It is found in central British Columbia and central Alberta, south in the western United States as far as northern California, Nevada and Utah, east to the border of the plains in Colorado. Its range is chiefly west of the Rocky Mountains. It is slightly smaller than the northern form.

The more familiar sharp-tail of the Middle West ( $P$. p. campestris) is abundant on the plains from southern Manitoba and southern Alberta, south through the United States to Wyoming and Kansas, east as far as Wisconsin and Illinois, and west to eastern Colorado. It is bright rusty in color and its dark markings are much less conspicuous than in the northern form.

The sharp-tailed grouse, which of late years has come to be known over much of the West as prairie chicken, is thus-in one or other of its three formsa bird of wide distribution. It is found from Kansas, on the south, to central Alaska on the north, and from British Columbia, California and Nevada, on the west, to James' Bay on the east. It occurs, as said, sparsely south of the Great Lakes, but in the United Statesexcept in this locality-its range is chiefly west of the Mississippi River. While during the greater part of the year it seems to be a bird of the prairie, it is yet often found high up in little mountain valleys, and often in a country that is completely wooded. 
Like many others of our best game birds, the sharptailed grouse has been so unremittingly pursued that it is rapidly becoming more and more scarce, and promises before long, in all regions where it is pursued with dog and gun, to become as rare as its relative, the pinnated grouse.

In habits the birds are all closely alike, except that we may assume that the northern form has modified its habits in accordance with its environment. Mr. Roderick MacFarlane found this species breeding in I884 near Fort Providence. The two last-named forms of the sharp-tailed grouse-which is also called white belly, speckle belly, willow grouse and pin tail-are common all through the northwestern United States. They are birds of the open land, yet at certain seasons of the year resort commonly to willows or brushy ravines, from which sometimes they get up in a thick flock, like a brood of gigantic quail.

E. E. Thompson, writing of the prairie sharptailed grouse in Manitoba, describes its prenuptial dancing in the following language: "After the disappearance of the snow, and the coming of warmer weather, the chickens meet every morning at gray dawn in companies of from six to twenty on some selected hillock or knoll, and indulge in what is called 'the dance.' This performance I have often watched. It presents the most amusing spectacle I have yet witnessed in bird life. At first, the birds may be seen standing about in ordinary attitudes, when suddenly one of them lowers its head, spreads out its wings 
nearly horizontally and its tail perpendicularly, distends its air-sacs and erects its feathers, then rushes across the 'floor,' taking the shortest of steps, but stamping its feet so hard and rapidly that the sound is like that of a kettle drum; at the same time it utters a sort of bubling crow, which seems to come from the air-sacs, beats the air with its wings, and vibrates its tail, so that it produces a low, rustling noise, and thus contrives at once to make as extraordinary a spectacle of itself and as much noise as possible.

"As soon as one commences all join in, rattling, stamping, drumming, crowing and dancing together furiously; louder and louder the noise, faster and faster the dance becomes, until at last, as they madly whirl about, the birds are leaping over each other in their excitement. After a brief spell the energy of the dancers begins to abate, and shortly afterward they cease and stand or move about very quietly, until they are again started by one of their number 'leading off.'

"The whole performance reminds one so strongly of a Cree dance as to suggest the possibility of its being the prototype of the Indian exercise. The space occupied by the dancers is from 50 to Ioo feet across. ... The dancing is indulged in at any time of the morning or evening in May, but it is usually at its height before sunrise. Its erotic character can hardly be questioned, but I cannot fix its place or value in the nuptial ceremonies. The fact that I have several times noticed the birds join for a brief set-to, in the late fall, merely emphasizes its parallelism to the drumming 
and strutting of the partridge, as well as the singing of small birds."

I have several times witnessed this dancing in November, just about the time that cold weather sets in, and have seen it carried on for two hours, immediately after sunrise, but have never been so fortunate as to get close enough to the birds to hear their stamping sound like a kettle drum. In the dances I have witnessed, there was heard not only the crowing, of which Mr. Thompson speaks, but also a sharp, high-pitched cackle, each note being separated from the other by a perceptible interval.

Some years ago I sent Major Bendire some notes on this species, which I quote here: "This species is partly migratory, and there is the very greatest difference in the habits of the birds in summer and winter. As soon as the first hard frosts come in the autumn, the birds seem to take to the timber and begin to feed on the buds of the willow and the quaking aspen. At this time they spend a large portion of their time in the trees, and are very wild. In the Shirley Basin, in western Wyoming, a locality where I have never seen any of these birds in summer, they are abundant in winter. At this season they live in quaking aspen thickets, along the mountains, and there I have seen hundreds of them roosting on top of a big barn, which stands just at the edge of a grove of quaking aspen timber. It was always easy in the morning, just after sunrise, to step out of the house, and with a .22 caliber 


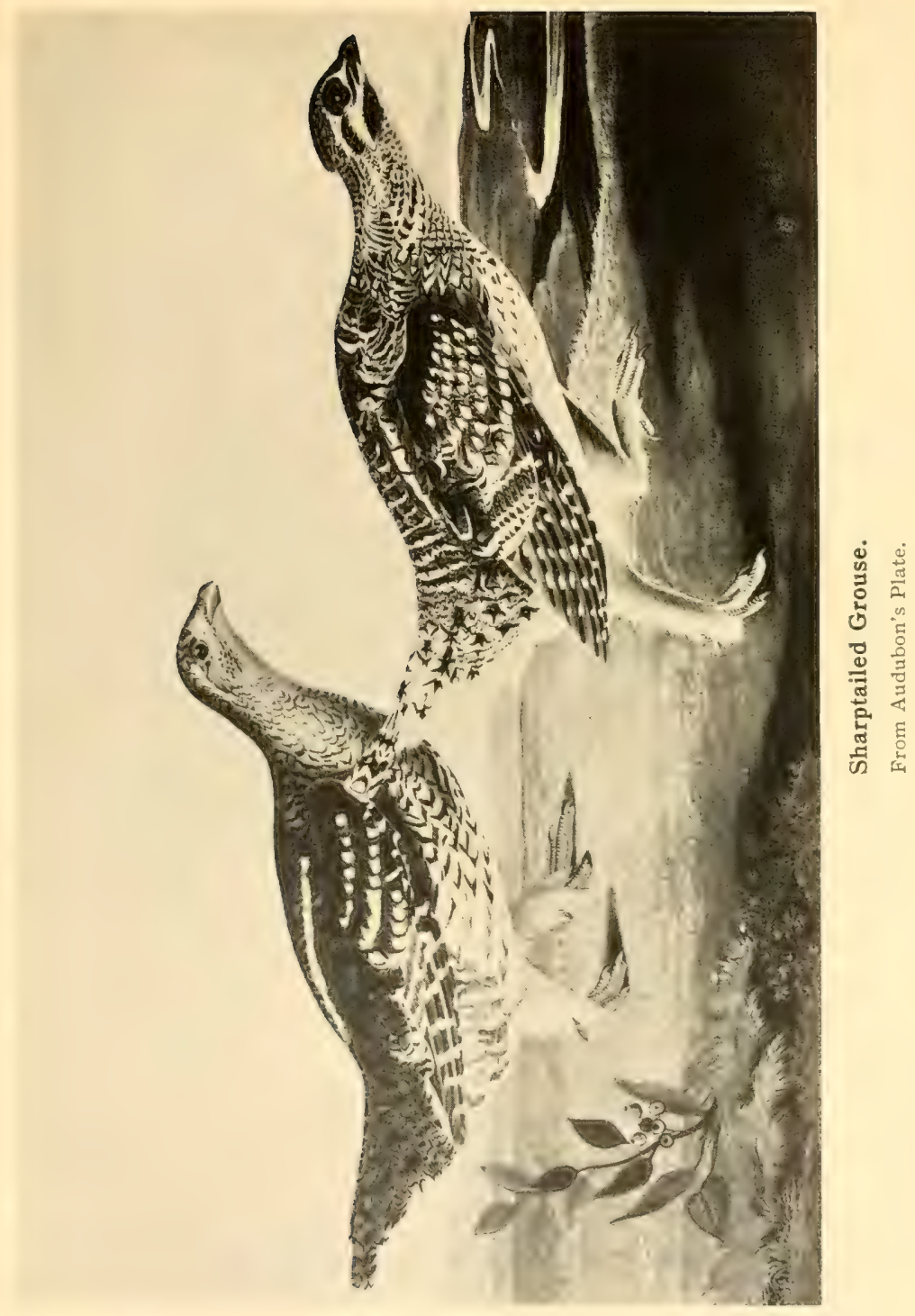



rifle shoot off the heads of as many of these birds as were needed for eating for the next two or three days.

"I have only one note on these birds which seems particularly worth mentioning, and of this I spoke in my report to Colonel William Ludlow, on the birds noticed during a reconnaissance to the Black Hills of Dakota in 1874 , which was published by the Engineer Bureau of the War Department. The sharp-tailed grouse has a cry which is unlike that of any other grouse with which I am familiar, although something very similar has been observed in the case, I think, of one of the ptarmigans. On the plains of Dakota in I874, having scattered a brood of sharp-tailed grouse, consisting of a mother and a dozen well-grown young, I sat down to wait for them to get together. The mother had flown to the top of a hill not far off, where she sat on the ground in plain sight, and after a few moments began to call to the young, which immediately answered her from the different points where they had taken refuge. The call of the mother and the young was a guttural, raucous croak, which quite closely resembled the croaking of a raven at a little distance. I plainly saw the old bird utter its note, and subsequently followed up the calls uttered by more than one of the young ones, until I started them, and killed one or two as they flew."

In winter the food of the sharp-tailed grouse consists largely of rose-berries and the buds of willows, cottonwoods and aspens. In summer and autumn, grasshoppers, insects and various berries, together with 
grass and the leaves of various plants, form their chief food. I have seen them feeding by hundreds in the alfalfa patches of the ranchmen, and have found their crops and throats stuffed with the green leaves, together with a few of the seeds. Almost everything in the nature of berries, insects, seeds and green leaves is devoured by this bird.

In the winter and autumn, the sharp-tailed grouse inhabiting a prairie country, spend most of their time in the river bottoms, among or close to the willow and cottonwood trees, on the buds of which they feed at this season, and it is not uncommon to see large flocks of them roosting among the branches of these trees in the early morning, apparently too much chilled to notice the approach of man.

Mr. E. E. Thompson, in his "Birds of Manitoba," describes in some detail the habits of the sharp-tailed grouse in winter. He says that it spends the winter nights in the snow, which is always soft and penetrable in the woods, though out on the plains it is beaten into drifts of ice-like hardness.

"As the winter wanes, it is not uncommon for a snow storm to be accompanied by sleet. The storm always drives the chickens into the drifts, and afterward levels the holes they formed in entering. The freezing of the sleet then forms a crust, which resists all attempts at escape on the part of the birds, many of which, according to the account of hunters, are starved and thus perish miserably. I met with a single instance of this myself. 
"Before the winter is over many of the birds, by continuously pulling off frozen browse, have so worn their bills that when closed there is a large opening right through, immediately behind the hook. Early in April the few that have survived the rigors and perils of their winter life spread over the prairie once more and soon scatter to enter on their duties of reproduction."

No one has written about this bird more charmingly than Dr. Elliott Coues, whose article on the prairie form is well worth quoting. He first heard the call of the sharp-tailed grouse in North Dakota, when he was alone in camp, not far from Fort Randall - at the time his home-where he had gone to shoot water fowl. He says:

"Awakened before it was light by the sonorous cries of the wild fow 1 making for the reedy lake where I had encamped, I arose--there was no need to dress-pushed off into the expanse of reeds in a light canoe I had brought with me, and with my gun across my knees sat quietly waiting for light to come. The sense of loneliness was oppressive in the stillness that preceded morning, broken only by the quack or plash of the wild duck, and the distant honking of a train of wild geese winnowing their sinuous way afar. I felt desolatealmost lost-and thought how utterly insignificant man is in comparison with his self-assertion. The grand bluffs of the Missouri, rising past each other interminably, were before me in shadowy outline, that seemed to change and threaten to roll upon me; all around stretched the waste of reeds, secret, treacherous, limit- 
less-unmoved, yet whispering to the water about their roots with a strange trickling. But the light came on; the distant hills took shape and settled in firm gray outline against the sky, and a breath of fresher, purer air, messenger of morning, passed over the lake, dispelling the vapors that hung reluctant, and causing the reeds to sway in graceful salute to the coming sun. A sparrow chirped from her perch with joy; a field lark rose from her bed in the grass, tuning her limpid pipe to a song of gladness; and the wild fowl plashed about right heartily, when the highest hilltop was touched with gold, and another and another, till the scene was illumined to the very bosom of the lake. The feathered orchestra sounds never so impressive as when it ushers in the day; never so fine and complete as when familiar voices sing the higher notes to the strange deep bass of the grouse; heard for the first time, as it was on this occasion, the effect is indescribable. No one could say whence the sound proceeded, nor how many birds, if more than one, produced it; the hollow reverberations filled the air, more like the lessening echoes of some great instrument far away, than the voice of a bird at hand. I listened to this grand concert, absorbed in the reflections it stirred within me, no longer alone, but in company I love, till the booming fell less frequently upon my ear, and then ceased-it was broad day; the various birds were about their homely avocations, and I must betake myself to practical concerns.

"Thus, in no faltering accents of timid expectancy, but in the bold tone of assured success, the grouse 
calls upon his intended mate to forget the shyness that will no longer serve their purpose; nor does the invitation lack defiance to a rival who may presume to dispute his rights. At the rallying cry the birds assemble, in numbers of both sexes, at some favorable spot, and a singular scene ensues as the courtship progresses. There is a regular 'walk-around,' as ludicrous, to the disinterested observer, as some of the performances on the comic stage. The birds run about in a circle, some to the right, others to the left, crossing each other's path, passing and repassing in stilted attitudes, stopping to bow and squat in extravagant postures, and resuming their course, till one would think their heads as well as their hearts were lost. But this is simply their way, and they amuse themselves in such fashion till the affair is settled. The cocks have bristled and swelled, strutted and fought, till some have proven their claims to first choice, and others have concluded to take what they can get. Their subsequent history, I am sorry to state, is neither particularly creditable to themselves nor of absorbing interest to us. Leaving them to go about their business in their usual humdrum way, let us look to what now occupies their mates.

"A nest will soon be required for her eggs, and the hen has to select suitable premises, though, being an architect of only the humblest order, she has little building work to do; and, moreover, not being fastidious, her choice is made without difficulty. I have found the nests in such various locations that I can hardly determine what her preference is, if, indeed, she have 
any. I suppose the site depends much upon circumstances. She will enter a tract overgrown with the low, scrubby willow bushes, so abundant in our higher latitudes, and settle beneath one of these; she will ramble along the edge of a wooded stream and hide in a patch of tall weeds; she will stroll out on the boundless, bare prairie, and take a tuft of grass at random. But wherever she makes down her bed she is solicitous to conceal it, not only from the rude glances of men, but from the equally cruel eye of her many four-footed enemies. Her method of concealment is most artfulperfected by its witlessness. With admirable instinct, she will avoid a place that offers such chances of concealment as to invite curious search; her willow bush is the duplicate of a thousand others at hand; her tuft of grass on the prairie is the counterpart of a million others around; her nest will be found by accident oftener than by design. And when, stooping over a warm nest on the prairie, whence she has just fluttered in dismay, we note how exposed it seems, now that it is found, we wonder how the dozen blades of grass that overarch the eggs, or the rank weed that shadows them, could have hidden the home so effectually that we nearly trod upon the bird before we saw her. She is now but a few yards off, in plain view, amid the scrubby prairie herbage, perhaps squatting, but more likely moving away with a swaying motion of the head at each step. We will not combine murder with the robbery we are about to commit, and let us hope she will be consoled in time. Lifting up the eggs carefully, one by 
one, we find the nest to be merely a few spears of grass, pressed down and somewhat circularly arranged with, in all probability, a few feathers that appear to have rather been mechanically detached from the mother bird than laid down by design. If the place is near our northern border, and early in June, we shall probably find the eggs quite fresh; but by the third week of that month they will be about hatching. At this period, should we, for any sufficient reason, destroy the setting bird, we should find her in sad plight-her plumage, harsh and worn, entirely gone from a large space on her belly; her flesh thin and flabby, and her crop containing only a few buds of some weed that grows close by her nest, with some grasshoppers or other insects.

"No bird is a more faithful mother than this grouse; no one clings to her eggs more steadfastly, or guards her young with more seclulous care. In proof of how close she will set while incubating, let me mention two instances that came under my observation. One poor bird was actually trodden upon and killed, and some of her eggs smashed. On another occasion, I drove a large four-mule ambulance over a nest; the animals shied as they stepped over it, when the bird fluttered out from between their legs. Stopping instantly, I discovered the nest just between the hinder wheels. The grouse lies hard and close, never relinquishing hope of escaping observation until the last moment.

"The young, as usual among gallinaceous birds, run about almost as soon as they are hatched, and it is in- 
teresting to witness the watchful solicitude with which they are cherished by the parent when she first leads them from the nest in quest of food, glancing in every direction, in her intense anxiety, lest harm befall them. She clucks matronly to bring them to brood under her wings, or to call them together to scramble for a choice morsel of food she has found. Should danger threaten, a different note alarms them; they scatter in every direction, running, like little mice, through the grass till each finds a hiding place; meanwhile, she exposes herself to attract attention, till, satisfied of the safety of the brood, she whirrs away and awaits the time when she may reassemble her family. In the region where I observed the birds in June and July, they almost invariably betook themselves to the dense, resistant underbrush, which extends for some distance outward from the wooded streams, seeking safety in this all but impenetrable cover, where it was nearly impossible to catch the young ones, or even to see them, until they began to top the bushes in their early short flights. The wing and tail feathers sprout in a few days, and are quite well grown before feathers appear among the down of the body. The first coveys seen able to rise on wing were noticed early in July; but by the middle of this month most of them fly smartly for short distances, being about as large as quails. Others, however, may be observed through August, little, if any, larger than this, showing a wide range of time of hatching, though scarcely warranting the inference of two broods in a season. 
"Returning to the newly hatched chicks, we will note their characteristics as they progress toward maturity. The down in which they are clothed when hatched is rather dingy yellow, mottled on the crown, back and wings with warm brown and black; it extends to the toes, but leaves a bare strip along the hind edge of the tarsus; the bill and feet are light brown. They are about as large as bantam chickens of the same age, and very pretty little things, indeed. They are very quick in their movements, scrambling to squat and hide on the least alarm, even at this early age. . . . "Throughout the region of the Red, Pembina and Souris or Mouse rivers, where I observed the birds during the summer, I found them mostly in the underbrush along the streams, which they seemed to seek instinctively as affording the best shelter and protection, as well as plenty of food. Where they were most abundant I frequently observed the 'scratching holes' in the bare earth among the bushes, where they resorted to dust themselves, and, most probably, in the instances of ungrown coveys, to roost. Late in the summer and in September, those who cared to shoot the tender young found them to lie well to a dog; in fact, to lie so close that they were flushed with difficulty without one. No game birds could be tamer or more readily destroyed. Except when temporarily scattered by molestation, the coveys kept close together, and only occasionally left the covert to stray on the adjoining prairie. They appeared to be feeding chiefly on wild-rose seeds, and those of another kind of plant 
equally abundant along the river bottoms. The majority of these birds were ungrown up to September, and scarcely any had at that date begun to assume their new plumage. Up to this time I do not recollect that I ever saw one alight in a tree; and they were still, for the most part, under charge of the parent, as separate families, rather than as the indiscriminate packs in which they afterward associate. With the advance of the month these family associations seemed to break up, the change of plumage was finished, the birds grew strong of wing, and able in all respects to look after themselves. No longer solicitous of shelter, they haunted the innumerable ravines that make down to the streams, and strolled in company far out on the prairie. In this region, at least, they showed little wariness all through the month. I could generally walk up to a covey in fair view on the bare prairie, even to within a few feet, before they would fly, and they seldom went far before realighting. Their appearance when not obscured by the herbage is characteristically peculiar. They seem to stand remarkably high on their legs, and generally carry their short, pointed tail somewhat elevated; the singularity is increased when the long neck is outstretched, as it generally is when they are on the lookout. On alighting after being flushed, if not much alarmed, they often stand motionless at full height, but if badly scared, squat closely, and are then difficult to find if not exactly marked down. If without a dog, one may pass and repass among them without finding one, unless he happen to stumble on 
them; and often, going away after such want of success, one may look back to find the heads of the whole lot raised above the grass, intently regarding his retreat. It is astonishing how closely they can squateven laying the head flat upon the ground, and appearing scarcely half their natural size. At this season their food appears to be chiefly grasshoppers. I have opened numbers to find their crops crammed with these insects, only varied with a few flowers, weed-tops, succulent leaves, and an occasional beetle or spider.

"By the first of October the sharp-tailed grouse have mostly finished the renewal of their plumage, are all full grown and strong of wing; their habits are considerably modified. They grow wary and watchful, flushing often at long distances to fly clear out of sight, and running far on the ground. They also begin to alight on trees, a habit, however, not confirmed until somewhat later, when, with the advance of cold weather and the failure of former supplies of food, they assume the routine of their winter life. The close coveys of the earlier season are for the most part broken up, and the birds wander often alone in search of food. They haunt the interminable ravines along the Missouri, making away from the river bottoms in search of food, but mostly returning at evening to roost in the trees. Early in the morning they may be seen leaving their perches in straggling troops, flying high and swiftly to other feeding grounds; and again in the evening, if one loiter beneath the immense cottonwoods, where, during the day, scarcely a chicken was 
to be seen, he will observe their return, till the trees are almost covered, and the air resounds with the hoarse $k u k-k u k-k-k-k$. Frequently, in very cold and especially in falling weather, the grouse will not leave their perches during the day, but may be seen at any hour roosting quietly in the tops of the tallest cottonwoods. They are decidedly not graceful objects under these circumstances. They look very large, sharply defined among the bare straggling branches against the gray sky, and assume ungainly attitudes, particularly when standing erect on their long legs, with outstretched necks and upturned tails. Their behavior under these circumstances varies in a manner to me inexplicable. Sometimes a group thus scattered among the treetops will permit the closest approach desired, and more than one may be brought down before the rest are off in alarm; not seldom one may fire twice or thrice at the same bird without dislodging it, or kill several without stirring from his tracks. But ordinarily the chickens' wits serve them to better purpose than this. As we approach, when just beyond range, the crackling of the underbrush attracts the attention of one of the birds, which before had been squatting 'like a bump on a log'; he rises on his feet and twists his neck around to have a look. The rest follow his example. A moment more the warning $k u k-k u k-k$ sounds, and the nearest bird leaves his perch-the cry is taken up by the rest, and the whole are off to settle again a few hundred yards away, and tempt renewed pursuit that is likely to end as unsuccessfully. From 
the sportsman's standpoint, the arrangement is wholly unsatisfactory when the birds behave so; nor when they are tame is it much more attractive; for, unless a supply of meat be the only point, dropping chickens from the trees is no more exciting than robbing a hen-roost. Killed under these circumstances, the food of the grouse is readily ascertained; in the dead of winter it consists chiefly of the berries of the cedar, and buds of the poplar or cottonwood and willow, still closely sealed, awaiting the coming of spring. I have taken from one crop a double handful of such food, almost as dry as when swallowed. This diet does not improve the quality of the flesh; a chicken at this season is quite a different thing from one killed earlier in the season. The rating of the grouse as an article of food necessarily varies, not only with circumstances, but according to individual preferences. I, myself, do not esteem it very highly. A tender young grouse, early in the season, is not to be despised, but all such specially flavored meat is likely to soon become distasteful, especially if, on one or two occasions, a person has been forced upon a surfeit of it. Confined to grouse for a few days, most persons, I should judge, would find relief in mess-pork.

"The mode of flight of this species is not peculiar; it rises with a startling whirr from the ground, till it attains a certain elevation-its straight, steady course, performed with great velocity by alternate sailing and flapping, are points it shares with its relatives. The wing-beats are rapid and energetic, giving it an im- 
pulse that enables it to sail long distances, when the wings are held stiffly expanded to their full extent, somewhat decurved, and with the points of the quill feathers separated. The bird's voice is highly characteristic. It is so almost invariably uttered during flight, at particular moments with reference to the delivery of the wing strokes, that for some time after my first acquaintance with the birds I was in doubt whether the sound were mechanical or vocal; nor was the uncertainty removed until I had heard it from the birds at rest. The ordinary note of alarm is almost invariably sounded just before the bird takes wing, whether from the ground or from a tree, and is usually repeated with each succeeding set of wing-beats, seeming to be jerked out of the bird by its muscular efforts. But we hear it also when, the bird being at rest, it becomes alarmed, yet not sufficiently to fly away; and when a bird is passing at full speed, sufficiently near, we may clearly distinguish the mechanical whirring sound of its wings, as well as, sometimes, the creaking rustle of its tail feathers as it turns its flight. When roosting at ease among the trees, and probably at other times, the grouse have a different set of notes - a sociable cackling or clucking, with which they entertain each other.

"In conversation with Captain Hartley, of the Twenty-second Regiment, an accomplished sportsman, well acquainted with the ways of our game birds, I was informed of an interesting point of difference in the habits of this bird and the pinnated grouse. In 
entering a cultivated field the latter goes on foot, and may consequently be readily trailed by a dog, while the sharp-tail flies in, and is only likely to be overhauled by the dog's winding it, or coming accidentally upon it. The same gentleman has noted the preference of this species for the skirts of woods, brush and broken places generally, in contrast to the entirely open places which the pinnated grouse frequents."

The eggs of the sharp-tail, while often plain creamcolored, are at times greenish in color and are sometimes marked with small spots of reddish brown and lavender. They do not appear to lay such large clutches as the pinnated grouse, though, after all, the difference in numbers is not marked. 


\section{SAGE GROUSE.}

\section{Centrocercus urophasianus.}

The sage grouse may always be recognized by its great size and by the fact that its tail is longer than the wings, and is graduated, with narrow pointed quills. The upper plumage is gray, variously marked and streaked with black. Some of the tertiary feathers are tipped with white or streaked with white; the chin, cheeks and throat are spotted black and white, but there is usually a distinct white streak on the side of the head running a short way back of the eye. The neck is black in front, while the fore breast is white or grayish, and on either side of the lower neck in the whitish areas are stiff, coarse hair-like feathers. The belly is black, and the lower tail coverts black tipped with white. The male is from 26 to 30 inches long, with a wing of from $I 2$ to $\mathrm{I} 3$ inches, and a tail about the same length. The birds weigh from 4 to 8 pounds. The female is much smaller; has the chin and throat white and the black patch on the front of the neck speckled. Half-grown birds are browner than their parents, with a warmer tone of rufous in their plumage, more like the young of the dusky grouse. The length of the female is from $2 \mathrm{O}^{\mathrm{T} / 2}$ to 23 inches.

Excepting the wild turkey, the sage hen, as it is often 
called, is the largest North American gallinaceous bird. Full-grown males sometimes almost equal the female wild turkey in size, and have been reported to weigh about eight pounds.

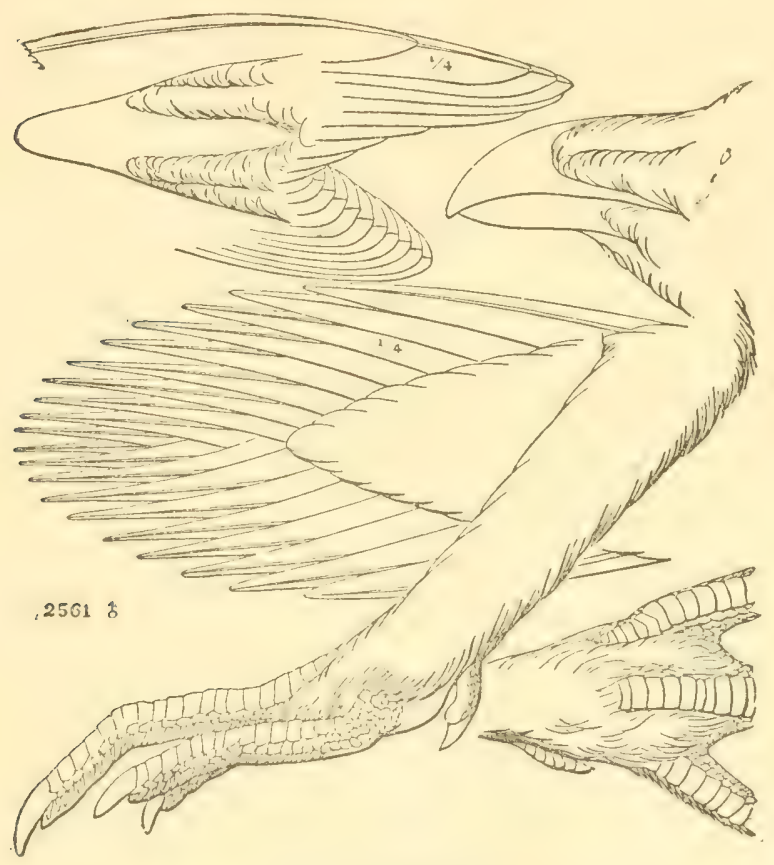

SAGE GROUSE

The sage grouse is an inhabitant of the high, dry, artemisia or sage-brush covered plains of the Western States. It is found on the plains and flanks of the Rocky Mountains, in the great central plateau, in the northwest territories, and in parts of southern British 
Columbia. Its eastern range covers parts of North Dakota, and extends thence westward through Montana, Wyoming and Utah to Oregon, California and Nevada.

The sage grouse is interesting from the fact that it possesses a soft, membranous stomach; in this respect differing from other gallinaceous birds. Its food varies with the seasons, and no doubt in winter the leaves of the so-called sage brush make up the most of this.

The sage grouse takes its name from this plant, on which, at certain seasons, it feeds extensively. Yet it eats other food, including grain. In Forest and Stream of August 29, I889, Mr. George H. Wyman says: "The sage cock will eat the leaves from a sage bush when it cannot get berries or grain, but it will go farther for a morning's feed from a wheat field than any bird I know, except the wild geese. I have killed sage fowls with stomachs filled with ripe wheat picked up the same morning in places where none was to be had nearer than eight miles, and in fact with no cultivation of any kind nearer in any direction. They fly long distances in search of food, but return to roost in the same place at night, generally on some steep hillside, free from shrubs or high grass." This may have been an error of observation. Very likely there was some unknown source of grain supply nearer at hand. But this, of course, cannot be proved. It is stated by some observers that sage leaves are resorted to only when other food is hard to obtain; but this is a mistake. The leaves and flowers of the sage have been found 
in the crops of adults and young during the season of greatest food supply. The leaves, blossoms and the pods of other plants, together with many seeds and grasshoppers and crickets, are said by Captain W. L. Carpenter to constitute a large part of this food. Mr. Robert W. Williams is quoted by Captain Bendire as having taken a bird, the crop of which was filled with the blossoms of a species of goldenrod (Solidago).

In past years controversies as to the edibility of the flesh of the sage cock have often taken place, some writers holding that the flesh is so strongly flavored by the sage that it is unpleasant to the taste, while others maintained with equal earnestness that the flesh was delicate and without unpleasant flavor. Obviously, the flavor of the flesh of any bird depends in great measure on the food which it eats, and birds which stuff themselves with a particular sort of vegetation, whether it be buds of the birch, of the laurel, of the spruce or of the wormwood, if left undrawn for a time may taste of the plant on which they have been feeding. It is a safe plan to dress the sage grouse as soon as may be after it has been killed, but even if this is not done, young birds are not likely to have a strong taste, though old ones may.

Like other prairie grouse, the sage cock goes through a courtship which is noteworthy. This is well described by Captain Bendire in his "Life Histories of North American Birds," in which he says :

"Early one morning, in the first week of March, I877, I had the long-wished-for opportunity to observe 
the actions of a single cock while paying court to several females near him.... His large, pale-yellow air-sacs were fully inflated, and not only expanded forward, but apparently upward as well, rising at least an inch above his head, which, consequently, was scarcely noticeable, giving the bird an exceedingly peculiar appearance. He looked decidedly top-heavy and ready to topple over at the slightest provocation. The few long, spiny feathers along the edges of the air-sacs stood straight out, and the grayish white of the upper parts showed in strong contrast with the black of the breast. His tail was spread out fan-like, at right angles to the body, and was moved from side to side with a slow, quivering movement. The wings were trailing on the ground. While in this position he moved around with short, stately and hesitating steps, slowly and gingerly, evidently highly satisfied with his performance, uttering, at the same time, low, grunting, guttural sounds, somewhat similar to the purring of a cat when pleased, only louder. This was kept up for some ten minutes. After having regained his usual attitude it was hard to believe that this was the same bird I had seen but a few minutes before."

Mr. Frank Bond has described at some length a hitherto unnoticed act of the male sage grouse, which he witnessed in Wyoming. The bird, after inflating its air-sacs, bent forward until its breast touched the ground and pushed itself forward along the ground. This action, carried on for days, seems to explain the 
wearing away of the stiff feathers on the lower neck and upper breast so often noticed in this species.

The nest of the sage grouse is usually placed at the foot of some sage bush, or sometimes at the foot of a bunch of rye grass, whose outer leaves, bending over, may conceal the nest. Commonly it contains from eight to eleven eggs, nearly as large as a hen's egg, greenish white or brownish in color, more or less heavily spotted with round, but not large, dots of brown and blackish. The period of incubation is given as twenty-two days.

There is little or no nest, and the eggs lie in a mere hollow scratched out in the bare ground. The sitting bird harmonizes so wonderfully with the ground on which she rests that one may pass within a foot or two without seeing her.

Major Bendire quotes Captain William L. Carpenter, U. S. A., who says: "I found a nest at Fort Bridger, Wyoming-where this species is numerousJune I, with nine fresh eggs. I was standing alongside a sage bush watching butterflies, several times looking down carelessly without seeing anything unusual, when, happening again to glance at the foot of the bush in the very place before observed, I saw the winking of an eye. Looking more intently, a grayish mass was discerned, blending perfectly with the color of the bush, which outlined itself into the form of a sage hen not 2 feet from my foot. She certainly would have been overlooked had not the movement of her eyelids attracted my attention. I stood there fully five minutes 
admiring the beautiful bird, which could have been caught in my butterfly net, then walked back and forth and finally passed around the bush to observe it from behind. Not until then did it become frightened and fly away with a loud cackling. The nest was a depression at the foot of a sage bush, lined with dead grass and sage leaves. The spot was marked and visited several times, always passing within a few feet without alarming the bird."

While the mother bird is sitting, the males are scattered over the prairie, two or three often being found together, and when alarmed starting off with heavy, lumbering flight to fly half a mile or a mile.

When hatched, the young leave the nest and follow the mother. When quite young they are as expert at hiding as are most of the grouse at this age.

They are active and hardy, and for the first few weeks of their life bear a certain resemblance to the young turkey, less perhaps in color than in length of neck and the active way in which they move about on their long legs. The mother is devoted, and Captain Bendire quotes Mr. Wm. G. Smith, who caught six young sage chickens one June in Carbon County, Wyoming, as saying:

"The female flew at my legs and followed me 200 yards to where my wagon was standing, constantly making hostile demonstrations, while the young kept calling."

The young families roost on the ground, on the sides of shallow ravines or on the prairie above, and 

the places where they have spent the night remind one much of the roosting place of a brood of quail. When full-feathered and half grown, they are very gentle and unsuspicious, and it used to be common to see a brood of them walk along feeding before a man who was following them up, trying to shoot their heads off with a rifle or a six-shooter. They paid no attention to the shots, but if one was wounded and fluttered about, all flew without delay. At this age they seem very social, constantly calling to each other with a high-pitched, pecping note, and if one wanders off from the flock or is left behind, he becomes very uneasy and runs hard in his efforts to orertake the family. When full grown, and at the approach of cold weather, the birds become more shy and fly more readily. On flying they give a hoarse cackle, somewhat like that of the sharp-tailed grouse, but deeper.

The sage grouse always roosts on the ground, and I have never seen them in what could fairly be called a tree. Captain Bendire reports having seen them on the horizontal limb of the juniper, about two feet from the ground.

A number of years ago, in response to an inquiry from him, I wrote Major Bendire as follows:

"On a very few occasions I have seen the sage grouse standing on the branches of a sage bush, sometimes 2 or 3 feet from the ground, but I imagine this is quite an unusual position for the bird. This species commonly, I think, goes to water twice a day, flying down to the springs and creek bottoms to drink in the 
evening, then feeding away a short distance, but roosting near at hand. In the morning they drink again and spend the middle of the day on the upland. The young birds, when feeding together, constantly call to one another with a low, pecping cry, which is audible only for a short distance. This habit I have noticed in several other species of our grouse, notably in the dusky grouse and sharp-tail.

"In western Wyoming the sage grouse packs in September and October. In October, I886, when camped just below a high bluff on the border of Bates' Hole in Wyoming, I saw great numbers of these birds just after sunrise, flying over my camp to the little spring which oozed out of the bluff, 200 yards away. Looking up from the tent at the erge of the bluff above us we could see projecting over it the heads of hundreds of the birds, and as those standing there took flight, others stepped forward to occupy their places. The number of grouse which flew over the camp reminded me of the old-time flights of passenger pigeons that I used to see when I was a boy. Before long the narrow valley where the water was, was a moving mass of gray. I have no means of estimating the number of birds which I saw, but there must have been thousands of them."

Although the sage hen is a large bird, rises slowly, and lumbers off with a good deal of noise, nevertheless, after they have attained their full growth, it is not always easy to hit these birds when in full flight, especially if going with the wind. 
Except when in flight, the sage grouse is deliberate in its movements, and I have seldom seen a bird on foot that appeared to hurry. More often they walk deliberately along; with heads stretched high, watching the intruder until the time comes for flight, when they spring from the ground with the cackling cry already mentioned and soon disappear over the next hill. The flight is often very much extended.

The only occasion when I recall seeing a sage grouse run was once when a bird that I had started flew several hundred yards and alighted in plain sight on a hillside on the other side of a valley. A marsh hawk, which was hunting near where the grouse alighted, flew to it and several times stooped at it and appeared to reach for it with its feet. The grouse at once started and ran swiftly along the hillside until it reached some high sage brush, the hawk following and now and then making a clumsy dive at it. 


\title{
THE WILD TURKEY.
}

\author{
Meleagris gallopavo. \\ Meleagris gallopavo silvestris. \\ Meleagris gallopavo osceola. \\ Meleagris gallopavo intermedia. \\ Meleagris gallopavo merriami.
}

America has given to the world its largest game bird and perhaps most important domestic fowl-the turkey. It is purely American, and its ancestry goes back a long way, for it existed here in far-off Tertiary times, portions of the skeleton of a turkey having been found in the Miocene deposits of Colorado, and the bones of other species in the post-Pliocene of New Jersey. Of these last, one was about the size of the existing turkey, but taller, while another was much smaller. At this time, the mastodon lived along the Atlantic coast, while the far older turkeys of Colorado had as associates the huge Brontotherium and many other creatures long extinct.

When the white men came to these shores they found turkeys in plenty. The flesh constituted a good share of the food of the natives, who wore cloaks or robes made of turkey feathers. Not very long after the discovery of the New World the bird was taken to 282 
Europe, and there received a variety of names in different countries, most of which referred to India, carrying out the early idea that America was a part of the Indies. Thus the bird was called by the English "cock of India"; in French, poule d'Inde, contracted to dinde,

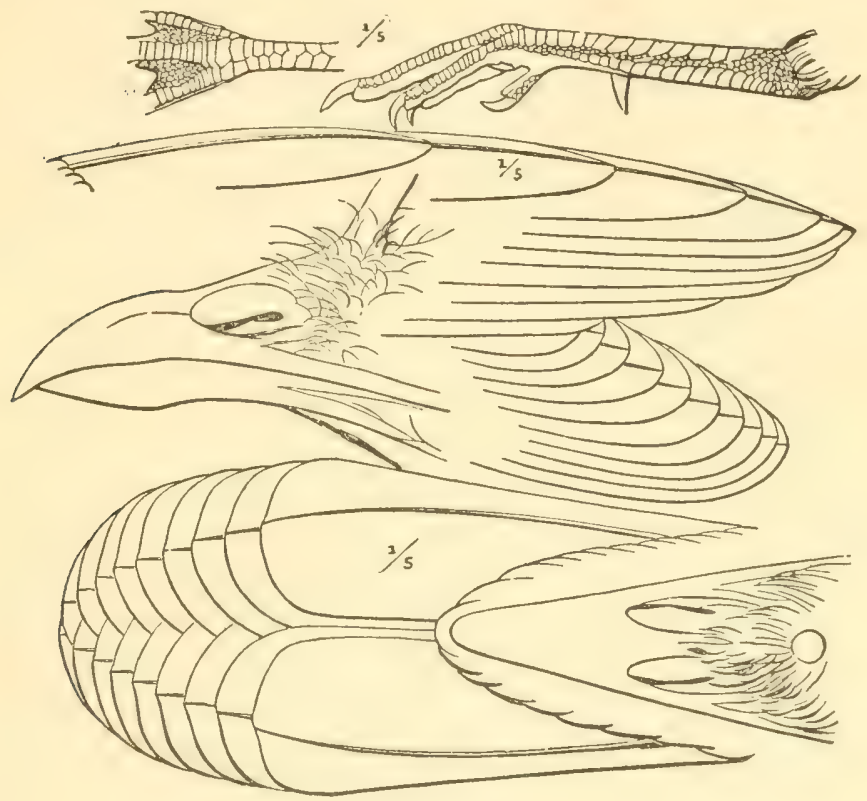

WILD TURKEY

hen of India; in Spanish, gallo or gallina de India, cock or hen of India; in German, Indianische Henne or Huhn, Indian hen, and also Calecutischer Hahn or Henne, cock or hen of Calcutta. It was also called by the Spaniards the Moorish hen, referring to a supposed 
African origin, while in Egypt the Arabic name is Dik rumi, fowl of Turkey.

Precisely why it should have been called turkey by the English it is hard to say, except that as Turkey was a part of the Far East, it may have been supposed to have some relation to India. It has been suggested that the name by which we know the bird is a corruption of a Hebrew word tukki, said to mean peacock, that this term was applied to the turkey, when it was received in Spain, by the Jews, who then monopolized the business of selling poultry, and that from this point of first introduction the name spread with the bird over a part of Europe.

This bird, taken to Europe by the Spaniards soon after the conquest, was the Mexican turkey.

The common wild turkey once found over most of eastern North America was for a long time the only form known in the United States, and this was thought to be the progenitor of all the domesticated races of turkeys. In I856, however, the English naturalist, Gould, described the Mexican turkey as a distinct species, and much later other observers called attention to a turkey from Florida differing slightly from the ordinary wild turkey, and to yet another different one from the Rio Grande. Later still, E. W. Nelson found that the turkey of Arizona presented constant, if slight, differences from the wild turkey of the plains and that of Mexico, and described it as Merriam's turkey.

To the untrained eye the differences between certain 
of these subspecies are slight, and the sportsman will do well to try to learn the geographical ranges of the different forms, for in most cases the locality will be to him a better guide in identifying the bird he kills than will any color description. The Mexican turkey is markedly different from the bird of the East, and the two will readily be distinguished. The differences between the various turkeys are found chiefly in the coloring of the rectrices, or tail feathers, and of the tail coverts and the primaries.

The original wild turkey-to which the name Meleagris gallopavo was given-has been shown to be the bird later described by Gould as the Mexican wild turkey. It is notably different from the eastern form, for its tail, tail coverts and the feathers of the lower rump are tipped with white or whitish, while the eastern and northern turkey has those feathers tipped with deep rusty or even with rich dark chestnut. The ordinary domestic turkey shows the whitish tippings of the feathers of tail, tail coverts and lower rumpcharacters derived from its ancestor, the turkey of Mexico. The Mexican turkey occupies the wooded mountain slopes bordering the Mexican tablelands on the south and west, ranging north to Chihuahua, but it does not reach the United States. Mr. Nelson has shown where it grades into Merriam's turkey on the north, while to the south in southeastern Mexico and Central America, it is replaced by a strikingly distinct species, the brilliantly hued ocellated turkey.

The eastern wild turkey, which was long considered 
the true Meleagris galloparo, thus becomes a subspecies of the Mexican turkey and is now known as Meleagris gallopavo silvestris. It and the closely similar Florida race (osceola) have the ends of the upper tail coverts and tail feathers dark chestnut. The common northern wild turkey has the primaries, or stiff quill feathers of the wing white barred with black, while the Florida wild turkey has the primaries black, with small white bars, which are broken and usually do not reach the shafts of the feathers. These differences are constant, otherwise they would not be regarded as subspecific characters.

Down in parts of southern Texas and northeastern Mexico is found another subspecies (intermedia) known as the Rio Grande turkey, or Elliott's turkey. It looks much like the common "wild turkey, but the rump feathers have a coppery bronze bar across them close to the ends, and are tipped with dark yellowish. The tail coverts are chestnut, with narrow black cross bars, and are broadly tipped with buff. The tail is mottled pale chestnut and black, has a black bar across it close to the end, and is tipped with yellowish buff. The difference in appearance between Elliott's turkey and the common turkey is not easily expressed in words, but any one who has an opportunity to compare two specimens of the same age and sex will readily see that they are not exactly alike. Moreover, the female of the Rio Grande turkey has grayish tips to the feathers on the upper part of the body, and thus differs strikingly from any other species of turkey. 
From the wild turkey of the East, Merriam's turkey may be distinguished by the whitish tips of the feathers of the lower rump, tail coverts and tail. From the Mexican turkey it may be known by its velvety black rump and the greater amount of rusty rufous, succeeding white tips on the tail coverts and tail, and by the distinct black and chestnut barring of the middle tail feathers.

Merriam's turkey thus appears to be about midway between the eastern wild turkey and the wild turkey of Mexico, and in fact the eastern wild turkey grades into Merriam's turkey, as Merriam's turkey grades into the Mexican turkey, whose white-tipped tail coverts and white-tipped tail, as seen in the domestic turkey, are so characteristic.

So in North America we have five forms of turkey, the ranges of which are fairly well defined.

The Florida wild turkey (Meleagris gallopavo osceola), described by Scott about twenty years ago, is confined to Florida, but the precise limits of its range are not yet known. The type specimen came from Tarpon Springs, Fla.

The Rio Grande turkey (Meleagris gallopavo intermedia) was described by the late George B. Sennett in I892. It is a striking bird, found in the lowlands of southern Texas and also in northeastern Mexico, where it ranges from the coast lowlands up to over 3,000 feet in the adjacent mountains.

Merriam's turkey (Meleagris gallopavo merriami) was described by E. W. Nelson in 1900. It ranges 
from southern Colorado south through Arizona and New Mexico, and grades into the Mexican turkey on the south and into the eastern wild turkey on the east. On all streams flowing east from the Rocky Mountains over the great plains, from the Niobrara, which is near the northern boundary of Nebraska, south nearly to the Rio Grande, turkeys were formerly common, and these were the ordinary bird of the Mississippi Valley. They lived along these various rivers, many of which have their heads in the mountains, and following up these streams to the mountains, there intergrade with the mountain bird. E. W. Nelson has shown where this takes place.

In these days, when the common wild turkey is extinct over much of its former range, it is very difficult to define with exactness the former boundaries of that range. We know that it was abundant in southern New England and to the south. Audubon speaks of it rather vaguely as found in southern Vermont, New Hampshire and Maine, and it is certain that it was once very abundant in Massachusetts, where many years ago I saw a skin taken at Mt. Tom about 1848 or I849.

$\mathrm{Wm}$. Brewster, in his admirable volume on the "Birds of the Cambridge Region of Massachusetts," published in I906, as No. IV of the Memoirs of the Nuttall Ornithological Club, has gathered much interesting information concerning the turkey in eastern Massachusetts and in Maine. He says:

"Morton, referring, no doubt, to his experience at 


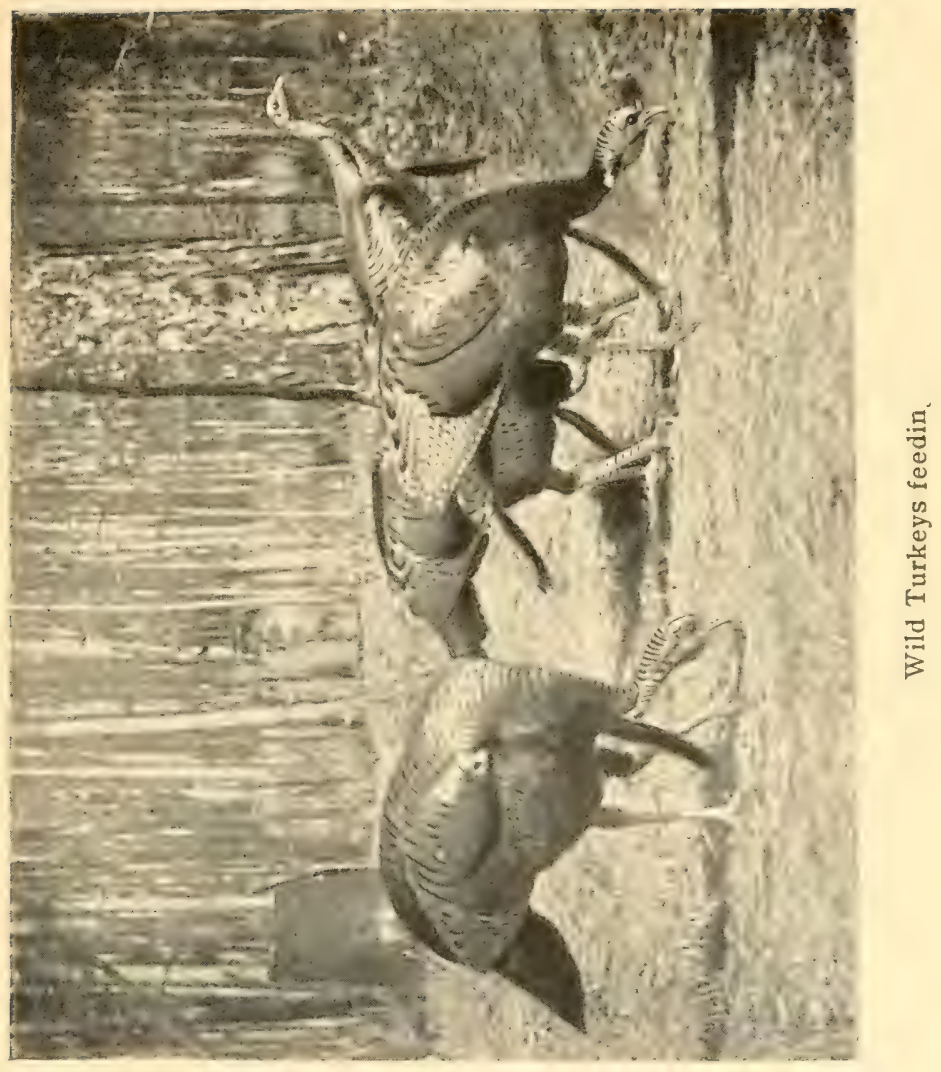



Merrymount, now Wollaston, only a few miles south of the Cambridge region, where he lived from 1625 to $\mathrm{I} 628$, and again in I629 and 30 , says: 'Great flocks (of turkeys) have fallied by our doores; . . . I had a Salvage who hath taken out his boy in a morning, and they have brought home their loades about noone. I have asked them what number they found in the woods, who have answered, Neent Metawna, which is a thosand that day.' Wood confirms this by stating that 'sometimes there will be forty, three score, and an hundred of a flocke, sometimes more and sometimes lesse; their feeding is Acornes, Hawes and Berries, some of them get a haunt to frequent our English corne: In Winter when the Snow covers the ground they resort to the Seashore to looke for Shrimps and such small Fishes at low tides. Such as love Turkie hunting must follow it in Winter after a new falne Snow, when he may follow them by their tracts; some have killed ten or a dozen in halfe a day; if they can be found towards an evening and watched where they peirch, if one come about ten or eleaven of the clocke he may shoote as often as he will, they will sit unlesse they be slenderly wounded. These Turkie remaine al the yeare long, the price of a good Turkie cocke is foure shillings; and he is well worth it for he may be in weight 40 pound; a Hen two shillings.' Josslyn mentions seeing, probahly at Black Point (now Scarborough), Maine, 'threescore broods of young Turkies on the side of a Marsh, sunning of themselves in a morning betimes, but this was thirty years since [in I63S or 1639], the English and 
the Indian having now [1671] destroyed the breed, so that 'tis very rare to meet with a wild Turkic in the Woods.'

"That the species was formerly found throughout the Cambridge region, there can be no reasonable doubt. Turkey Hill in Arlington may well have derived its name from the presence there of this noble bird in early Colonial days. Indeed, Mr. Walter Faxon writes me that an acquaintance of his has seen 'in a manuscript diary of the ancestor of an Arlington man ... an entry of killing some Wild Turkeys in the region about 'Turkey Hill.' At Concord, less than ten miles further inland, the species had not become wholly extinct at the beginning of the past century. The late Steadman Buttrick of that town, a keen lover of field sports and a man of undoubted veracity, who died in I874, used to delight in narrating how, when a boy, he had made repeated but invariably fruitless expeditions in pursuit of the last wild turkey that is known to have lingered in the region about his home. $\mathrm{He}$ often saw the bird, a fine old gobbler, but it was so very wary that neither he nor any of the other Concord gunners of that day ever succeeded in getting a fair shot at it. It was in the habit of roosting in some tall pines on Ball's Hill, whence, when disturbed, it usually flew for refuge into an extensive wooded swamp on the opposite (Bedford) side of Concord River. Mr. Buttrick was born in I796. As he was presumably at least twelve or fifteen years of age before he began to use a gun effectively, it is probable that his experience 
with the wild turkey happened some time between I 808 and ISI 5."

The turkey was abundant in the southwestern portions of the province of Ontario and occurred through much of New York, in Pennsylvania and Ohio, from which last State it has been exterminated in comparatively recent years. It is said that a few turkeys still linger in Pennsylvania. Michigan, Wisconsin, southern Minnesota and Iowa all once had turkeys enough. They were abundant in Nebraska, reaching beyond the northern boundary of the State, for Captain W. L. Carpenter found turkeys on the Niobrara River, and Dr. Coues speaks of good evidence of their occurrence as far north as Yankton on the Missouri-about the same latitude as the mouth of the Niobrara. It is well understood that the turkey was fairly abundant on many streams flowing into the Missouri or its tributaries south of the Platte River, and undoubtedly they worked up many of these streams into the mountains. Indians in whom I have confidence have told me of killing turkeys on tributaries of the South Platte in the mountains west of where Denver now stands. From that point south Merriam's turkey was undoubtedly abundant in the mountains. The turkey found on the plains to the south of the Platte, westward until the mountains are reached, is presumably the eastern form (Meleagris gallopavo silvestris).

Captain L. H. North, who as a little boy moved with his family into Nebraska in the year 1856 , says of the 
streams in eastern central Nebraska forty or fifty years ago :

"There were a good many wild turkeys here on the Loup River, the Elkhorn and Shell Creek when we came here. Ed. Chambers tells me they were often seen on the Niobrara River in early days-say in 1877. I do not recall that any turkeys were seen when the Pawnee scouts were out in 1867 , guarding the track layers on the plains toward the mountains, but at that time turkeys were found on the Platte River near old Ft. McPherson-not far below the forks of the Platte."

In August, I909, Forest and Stream printed a letter from me inquiring as to the western range of the wild turkey. This inquiry brought out some extremely interesting information which indicates that the former range of the turkey extended regularly to South Dakota. In my letter I asked what the northern and western range of the turkey was, and whether any of Forest and Stream's correspondents had ever known of its being found in the Black Hills. In response to this Sandy Griswold, of Omaha, Neb., sent to Forest and Stream a letter, from which I quote the essential paragraphs:

"The query whether wild turkeys ever got as far West as the Black Hills I am unable to answer; I do know, however, that no longer ago than I894 they had found their way as far as the foothills this side of the Black Hills in South Dakota.

"I was camped on the Lake Creek marshes that fall, duck shooting, and on the third of November Alfred 
Reshaw, a young halfbreed Sioux, who was one of our camp helpers and guides, killed a twenty-one-pound black and tan turkey in the scraggy pine hills along White River, twenty miles north of our camp and fortyfive or fifty miles this side of the Black Hills. He killed the bird flying, from out of a bunch of five which he had jumped from a patch of ground cherries on one of the bluffs. He knew what the birds were, as he and his brother had killed several the previous winter in the same vicinity.

"Two days later Alfred, the late George W. Scribner, of San Francisco, and I went to White River, where the Sioux had killed his gobbler, and although we hunted assiduously for hours up and down on both sides of the river, we found no turkey. We did find plenty of sign, however, in almost every rose thicket and among the dried ground cherries from which Alfred had flushed his birds. We found fresh tracks and fresh droppings, showing that the birds had been there after the day the Sioux made his kill.

"Along the White River in this particular region are extensive fastnesses well adapted to the fancy of wild turkeys, low scraggy acorn-bearing oaks, deep arroyos, with numerous springs, thickets of plum, crals and grape, rose fields, ground and choke cherry patches and many vegetable growths on which the birds feed in the fall and summer."

The Reshaws (Richard) are a well-known family of Sioux mixed bloods, descendants of one or more French 
Creoles who served the American Fur Company about I850 or earlier, and who married Sioux women.

Through the kindness of Colonel Hugh L. Scott, superintendent of the U. S. Military Academy, I am enabled to give the most northerly definite record of the wild turkey on the Missouri River of which I have any knowledge. Colonel Scott, learning of my interest in this subject, recalled that more than twenty years ago General D. L. Magruder, U. S. A. (retired), had told him of killing wild turkeys near Fort Randall, Dakota, in I855. He therefore wrote to General Magruder and received from him a letter dated September 6, I909, as follows:

"From July, I855, to October, I860, I was stationed at the different garrisons along that stream [the upper Missouri River] from old Fort Pierre Chouteau to Fort Randall.

"On December" I7, I855, I accompanied General Harney upon a hard winter's march, from Fort Pierre Chouteau to the mouth of the Niobrara River. The march was by land as far as the present site of Fort Randall, where we were compelled by heavy snowdrifts in the ravines to abandon the prairie and take to the ice upon the river, where the march was continued, both going and returning, until our arrival back at Fort Pierre, February I7, I856.

"During the trip, both going and returning, I killed deer, rabbits, grouse and turkeys to supply our mess, finding each of the kinds of game in plenty and quite fat in most of the heavily timbered points along both 
sides of the river. The turkeys were particularly fineflavored, their food being abundant, consisting mostly of wild grapes, rose apples (the seed pod of the wild rose), cottonwood buds and hackberries, the latter apparently their favorite, at least to judge by the quantity contained in their crops.

"The last turkey killed by me was at a return camp about thirty miles above Fort Randall. Beyond that point I have no personal experience, but while stationed at Fort Pierre I was told by the interpreter of the fort that turkeys formerly were quite abundant in the heavy timber about the mouth of the Big Cheyenne River about thirty miles above."

The statement made by the interpreter at Fort Pierre furnishes quite satisfactory eviclence that turkeys were once found on the Missouri River as far north as the mouth of the Cheyenne River.

Colonel Scott has also called my attention to the diary of Lieut. Rufus Saxton, printed in Vol. I, Pacific R. R. Reports, I853-4, which says of Cedar Island, on the Missouri River, below Ft. Pierre: "Saw wild turkeys for the first time. They are seldom seen above this point, and have never, I believe, been found beyond the Rocky Mountains." The reference, of course, is to the northern Rocky Mountains.

Alexander Henry, the Younger, states that in I806 the Cheyenne Indians coming up from the south brought with them the tails of turkeys which the Mandans and Minitari greatly desired for use as fans and for which they traded, and from this we may infer that 
there were no turkeys found on the Missouri or its tributaries as far north as the then location of those tribes-Knife River.

I suspect that in the Rocky Mountains turkeys seldom or never crossed the divide between the north and south forks of the Platte, and that they never got as far west as the Black Hills.

No bird is more gentle and unsuspicious than the turkey until it has learned that man is an enemy, and after that no bird is more wary and alert. Mr. Henshaw speaks of the lack of suspicion on the part of these birds, and Captain Carpenter tells how-when his command was preparing to establish Fort Niobrara-a wild turkey came to the camp and ventured out of the underbrush to feed on the grain spilled by the animals.

When Florida first began to be a resort for northern tourists, turkeys were very abundant and not at all shy or suspicious. They often associated with the domestic turkeys, and one wild gobbler became so tame that he would feed unconcernedly within a few feet of a man. On this point Dr. Ralph, writing about I890, said to Captain Bendire:

"One can hardly believe that the wild turkeys of to-day are of the same species as those of fifteen or twenty years ago [that is, I872 to I875]. Then they were rather stupid birds which it did not require much skill to shoot, but now I do not know of a game bird or mammal more alert or more difficult to approach. Formerly I have often, as they were sitting in trees on the banks of some stream, passed very near them, 


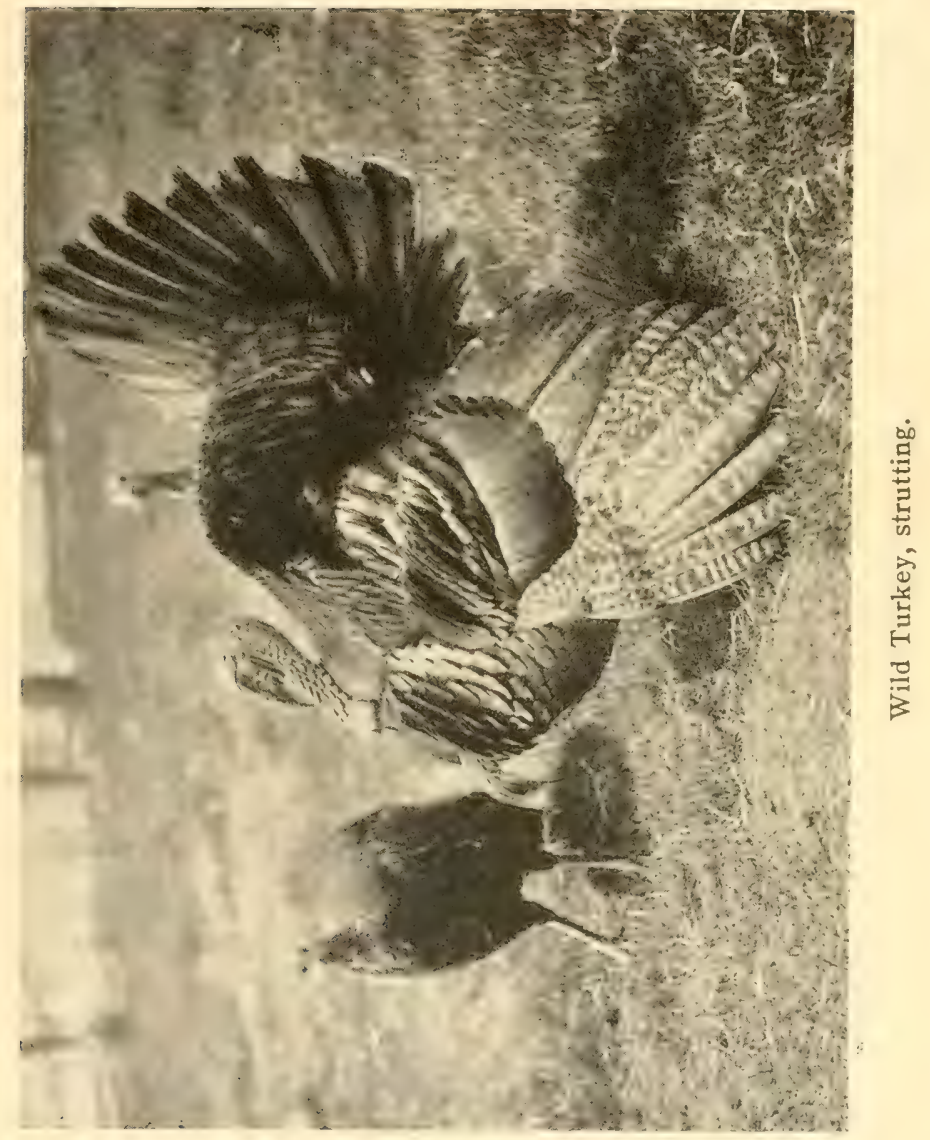



both in our boats and in steamers, without causing them to fly, and I once, with a party of friends, ran a small steamer within twenty yards of a flock which did not take wing until several shots had been fired at them."

The turkey, while usually resident in a certain section, is yet said to be prone to wander, and to be by no means as local in its habits as the bobwhite or the ruffed grouse. Sometimes they will remain in a desirable location for a long time and then will leave it-for no apparent reason. On the plains the birds used to spend the night roosting in the trees of the bottoms, and after drinking in the morning would wander up on the prairie about the heads of ravines and there feed on grasshoppers and other insects and on sand cherries and tunas, returning in the heat of the day to the shade of the underbrush or even of a cut bank.

Turkeys feed chiefly on vegetable matter. In old times the saying, that a good mast year was a good turkey year, passed into a proverb. They eat beechnuts, chestnuts, various acorns, pecan nuts, persimmons, the fruit of the cactus, all sorts of wild berries or seeds and grains and other vegetable matter, besides all insects. In the central and southern Rocky Mountains the fruit of the piñon forms a large part of their subsistence. As determined by the Biological Survey, the turkey's food consists of $15^{1 / 2}$ per cent. of animal matter and nearly $84 \mathrm{~T} / 2$ per cent. of vegetable matter. Of the vegetable matter, buds and leaves constitute nearly 25 per cent., fruit nearly 33 , and other seeds 
nearly 20 per cent. In the western country turkeys are great eaters of grasshoppers. They also destroy the tobacco worm and moth when they can get them.

The breeding season for the turkey ranges from February to May, according to the latitude which the bird inhabits. At the breeding time, and, indeed, throughout the year until mating in the early spring, the hens and young birds associate together and apart from the gobblers.

At mating time the gobbler's actions are those of the domestic turkey. He gobbles loudly, struts and spreads his tail, drags his wings on the ground and puffs himself out until he has made the proper impression on the hen. Often several birds are going through this performance about a single hen, and fights between the males are common, and, it is said, sometimes with fatal results.

The nest is a mere hollow scratched in the ground, lined or not lined with straws, grass and a feather or two. The eggs vary in number from eight to fourteen. Captain Bendire reports a case where there were twenty-six eggs in a nest, but two hens were at the nest, one sitting on the eggs and one standing close by them. It is likely, therefore, that occasionally two hen turkeys share a nest, as two quail sometimes do.

Like many ground-nesting birds, the turkey is exceedingly hard to see when on her nest, and of the turkey, as of other birds, various instances of this have been related. Captain B. F. Goss, writing May, I882, in southern Texas, says: 
"We were encamped quite near the nest; one morning I noticed a hen turkey stealing through the bushes and suspected she was going to her nest. We watched her carefully for three mornings, and having pretty nearly located the nest, commenced a close search, and examined, as we thought, every inch of ground. I was about giving up, when looking down almost at my feet, I saw the bird sitting on the nest. She at once ran; she had allowed me to pass several times within a foot of her without moving, and seemed to know at once when she was seen. I have often noticed this trait in birds of this genus; as long as unseen you can tramp all around them, but they seem to know at once when they are seen and lose no time in getting away."

As long as the hiding bird, which sees and hears its pursuer, is convinced that he is still ignorant of its position, it feels safe, but the moment it recognizes by the expression of the man's eye that its hiding place has been detected, it is off without delay.

The eggs of the wild turkey are not at all unlike those of the domestic bird. Usually they are creamcolored, dotted with finer or larger spots of reddish brown, chocolate and sometimes lavender. Captain Bendire states that the spots are more often very small and fine than large.

The young follow the mother as soon as hatched, but Audubon says, "As the hatching generally takes place in the afternoon they frequently return to the nest to spend the first night there." 
The young are believed to be very tender and subject to many dangers from dampness. Some writers declare that the mother leads them on high ground for the first week or two of their life in order that they may escape the dangers of dew or rain from the grass. Audubon says: "To prevent the disastrous effect of rainy weather the mother, like the skilful physician, plucks the buds of the spicewood bush and gives them to her young"' 'The little birds are able to fly at about two or three weeks old, and soon after that leave the ground and roost on the low branch of a tree sheltered under their mother's wings. When danger threatens, the mother turkey, like many other gallinaceous birds, calls to her young, which at once crouch and hide and cannot then be seen.

It is said that if the male turkey finds a nest of eggs upon which the hen is sitting he will destroy them, and that if he comes upon a brood of newly hatched young he will kill them. It is certain that during the autumn and winter the young birds and the females associate together, while the old males keep by themselves and do not begin to seek the society of their mates until the approach of spring.

In the Rocky Mountains the nests are built at an altitude of from 3,000 to 5,000 feet, but as the weather grows warmer and the snow disappears, the old hen leads the young up to the higher mountains, so that they finally summer at from eight to ten thousand feet. In the late autumn, when the weather grows cold and snows come on the mountain ranges, the birds move 
down again to sheltered cañons or timbered river valleys, where they spend the winter.

In the southern States turkeys have always been abundant and their stronghold is still there-parts of Virginia, the Carolinas, Georgia, Alabama, Mississippi, Louisiana, Arkansas, Missouri and Texas. Merriam's turkey is said to be almost extinct in Colorado, but is still abundant in Arizona and New Mexico. That there should be occasional outlying colonies of a few birds in Iowa and Nebraska, such as Mr. Griswold is told of, seems very surprising, but such colonies cannot last long unless protected by the owners of the land on which they live.

The turkey, grandest of game birds, has been exterminated over much of its former range. Great in size, and valuable for food, he is an object of pursuit wherever found. So, throughout the farming country of the North and West the turkey is gone and gone forever. As the country is settled up, is his complete extermination to follow? Domesticated, he will always survive, but should we not strive to retain the old wild turkey of the eastern States in his untamed wild state, self-dependent, one of the typical and interesting inhabitants of our primitive forests and our far-stretching southern plains? 

PART II

\section{UPLAND SHOOTING}





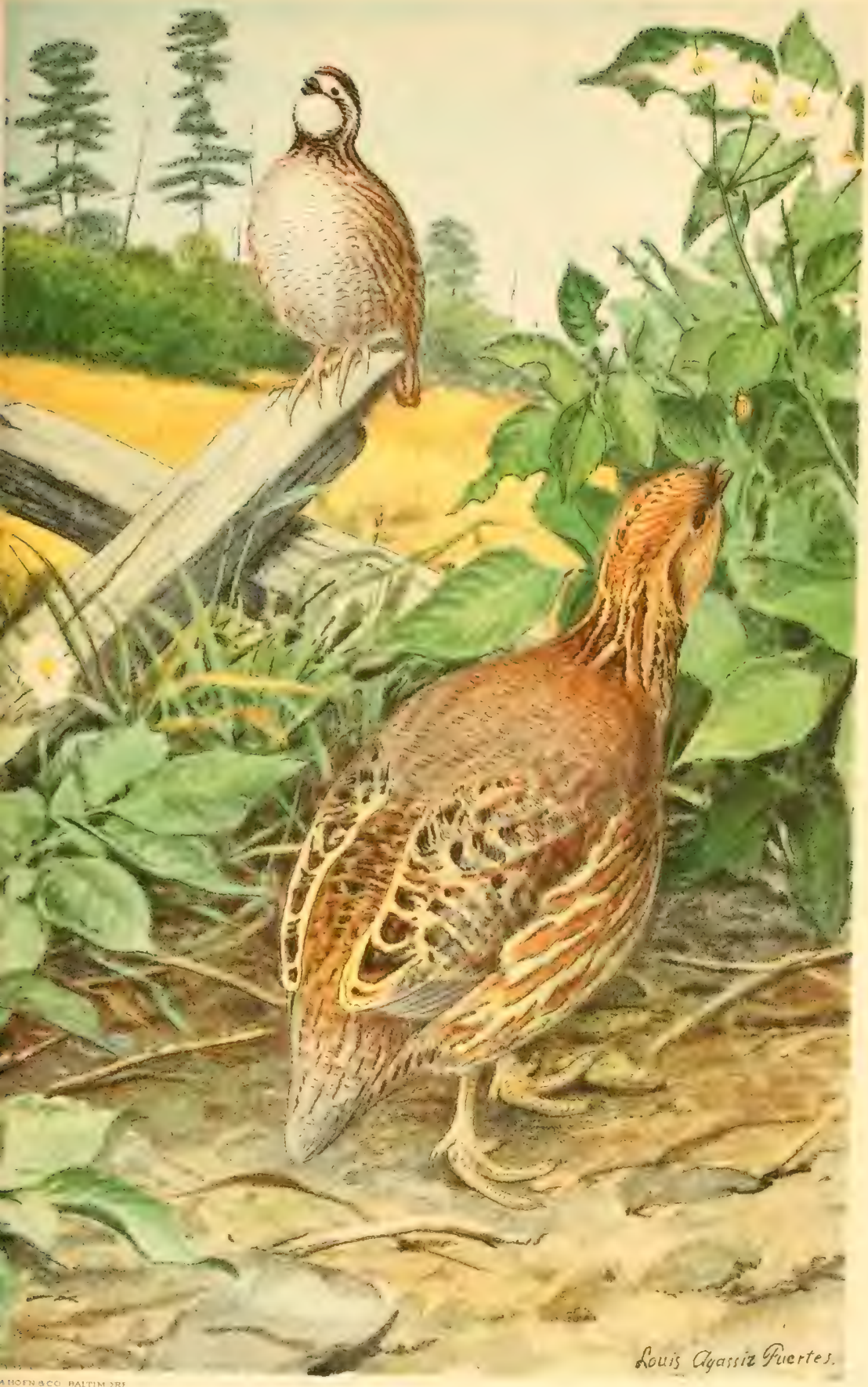

BOBWHITE IN POTATO FIELD. 



\section{UPLAND SHOOTING}

\section{WOODCOCK SHOOTING.}

Many years ago I contributed to the Contury Magazine an article on this species, and from it, by the kind permission of the Century Company, I extract a few paragraphs on some details of the woodcock shooting of those days. Birds were plenty then, as we may hope that some day they, will be again, if wise measures are taken for their protection.

The woodcock is not often seen and is quite contented to be overlooked. He has no brilliant song to catch the ear, no gaudy plumes to attract the eye, nor does he perform graceful evolutions high in the air in the broad glare of day. He is truly a modest fowl, and except at night, or during the twilight of morning or evening, he does not willingly venture into situations where he can be viewed by the casual wanderer through field or wood. One who desires to make his acquaintance must penetrate into the depths of the most tangled swamps to find him at home. Even here, during the day, he is ustally half asleep. Not so drowsy, however, as to be unaware of the approach 
of an intruder. The soft rustling of the leaves, the occasional snapping of a dry twig, and the sound of the heavy footfall rouse him from his doze or his day dream. He moves sideways beneath the spreading leaves of a tuft of skunk cabbage, and with head turned on one side, and great eyes spread to their widest, watches for the approaching form. Once in a while something may cause him to take the alarm and dart away before it is within sight; but usually he lies close, and when he rises it is near at hand. He springs from the ground uttering a shrill, twittering whistle and twists about in his upward flight to dodge the branches which spread in a network above him, until he has topped the undergrowth, and then darts off in a straight line for fifty or a hundred yards, to plunge once more into his beloved cover.

The dog is a most important auxiliary in woodcock shooting. A very few sportsmen employ cocker or field spaniels, which are trained to range close to the gun, and to give tongue as soon as they strike the scent, thus warning the shooter of the proximity of the bird and preparing him for its possible rising. But most men use the setter or pointer. A good woodcock dog should work close; that is, within sight of the gun. Often where the undergrowth is very thick, it becomes necessary to attach a bell to the dog's collar, so that if it pass out of sight for a few moments its whereabouts may still be known by the sound.

Late in November you will still find a few birds, and at this time they will be lusty and strong of wing, 


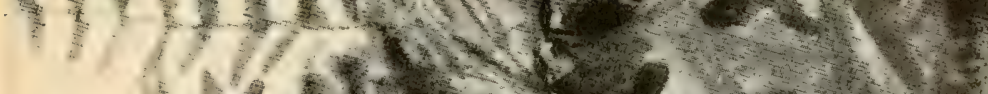

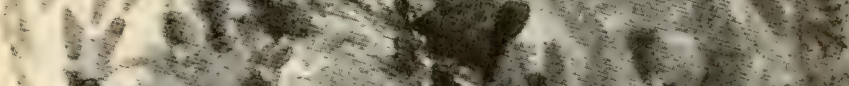
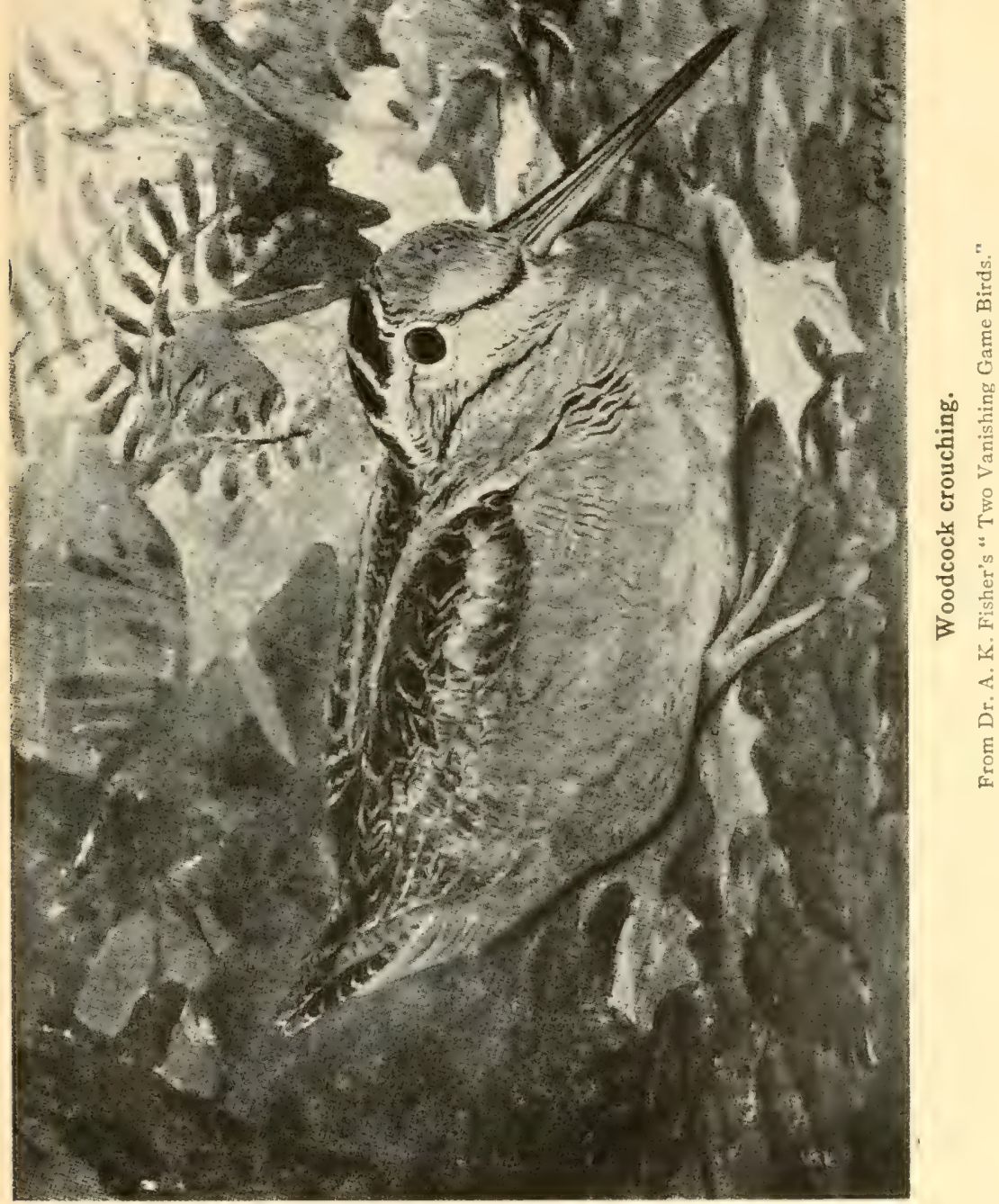

and will test your skill. Cross the meadows then and go down into the swamp, working along near the edge, where the underbrush is not too thick, and the soil under the leaves, as you can see in the cattle tracks, is rich and black. Just beyond you, on the left, a steep hillside rises sharply from the edge of the swamp, its surface overgrown with low cedars, sumacs and bayberry bushes. The old dog comes out of the swamp and turns toward the slope, and as he crosses before you glances back inquiringly. He knows the hillside, and understands as well as you do that a cock is usually to be found on that warm southern exposure at this time of the year. No need to wave the hand or use any elaborate signal to tell him to work up among the cedars and through the brush. A little sidewise movement of the head, and he is breasting the steep ascent and rustling among the twigs and the crisp leaves, while you walk along a cowpath at the foot of the slope. If there be a bird there it will be sure to fly toward the swamp, and must therefore cross in front of you. For a few moments you hear the dog as he works above you; then the sound ceases, and as you pause to listen for it there comes to the ear that shrill whistle, so like the midsummer twitter of the kingbird, that warns you to "mark cock." You see a brown flash among the green cedars, and the bird darts out to plunge into the swamp; but as he sees you he turns sharply and flies down the path, straight away. You have plenty of time; bring up your gun deliberately, cover the bird, and when it is 
about thirty yards distant fire, and it is yours. At the report of the gun your dog appears on the bank above, pauses a moment until you have slipped another cartridge into the gun, and then dashes off toward where the bird lies. A word steadies him as he approaches it, and after quartering once or twice the scent reaches his nostrils. He feels for it, then pauses, and at command steps forward, gently takes the bird in his mouth and trots slowly toward you, expressing as much pride and satisfaction in his face and in his slowly wagging tail as if he had captured the prize without any assistance of yours. On again, along the border of the swamp, sometimes stooping low to pass beneath the tangled underbrush, or forcing your way through the thick alders, making the dead stems crack and fly, or passing through a spot free from low shrubs, where the tall, gray trunks of the hardwood trees stand apart, and the footfall is scarcely heard on the damp, dead leaves. For some time the $\log$ works quictly ahead of you, manifesting none of the signs which would lead you to suspect that birds were near; but as you approach a little arm of the swamp which runs up a narrow ravine, the merry action of the setter's tail warns you to be prepared for a point. Yes, there, where the wind has swept aside the leaves, exposing the black mud beneath, you see in it dozens of little round holes, which tell you that the long bill has been at work here. Suddenly he stops, and stands quite still, except that the tip of his tail moves a little from side to side. As 
you step up to him he moves again, very slowly and cautiously, and then suddenly stops and remains motionless. It is a pretty picture, and one that the sportsman never tires of watching and admiring. The dog's fore foot is raised in the act of stepping, his tail is straight and rigid, head a little above the line of the back and slightly turned to one side, ears a little pricked. Walk up beside him and look at his face, and you will see, what his attitude already indicates, that he is laboring under strong excitement. His nose is perhaps within a few inches of the bird and the scent is strong. You will see his eyes roll as he looks over the ground before him. His forehead is knotted into a frown, which shows how thoroughly in earnest he is. ...

The bird is likely to fly up from beneath the dog's nose, so close to you that you cannot shoot without running the risk of either missing altogether or else blowing him to fragments, and will then, perhaps, dart behind a thick cedar or twist into some alders through which you can hardly see to shoot.

The alder runs, so numerous through the New England States, are most satisfactory places to work for woodcock. These are usually the channels of little brooks a few feet below the general level of the open meadows through which they pass. The ground is too damp to be successfully cultivated and the farmer gives it up to the black alder, which attains a height of from fifteen to twenty feet. Beneath these in the wet, springy soil, the skunk cabbage (Symplocarpus), 
a variety of ferns, and many other moisture-loving plants, grow in wild luxuriance. These runs, or swales, are often so narrow that the best way to hunt them, if two are shooting together, is for each to take a side and let the $\log$ work between them. The birds, when started, will either show themselves above the alders, or, what is more likely, will break out on one side or the other, and fly forward along the edge of the bushes, giving a perfectly open shot and one which not even a tyro ought to miss. In working out such places the bell should be put on the dog, for it is often so dark beneath the thick growth that it is difficult to see him. Should he come to a point, and the bird decline to rise, a heavy stick or stone thrown into the bushes just in front of him will often flush it.

One of the most instructive articles on woodcock shooting ever written is from the pen of Mr. B. Waters and was published in Forest and Strcam in the year I903. I am glad to be able to reproduce it-with a few minor changes - in these pages.

Of all the kinds of shooting of field and forest the sport of woodcock shooting holds the warmest place in the hearts of its devotees. The woodcock shooter is an enthusiast of enthusiasts. He may take a keen pleasure in bringing other game bircls to bag, but when woodcock shooting is under consideration comparison ceases. And indeed this sport possesses many fascinating features peculiar to itself. First of all, it can at best be indulged in only in very small quantities. There is but little of it when compared with the abun- 
dance of other kinds of shooting, for the woodcock is comparatively a rare bird and its season is a short one; therefore the keen edge of enjoyment of woodcock shooting is never dulled by surfeit. The habitat of the bird is distinctly different from the home of all other game birds, and on the earth's surface only tiny spots here and there meet the wants of its nature, and many vast tracts of fertile country have no woodcock ground at all.

It, too, is a bird of mystery, of whose coming and going no one knows. It is nocturnal in its habits, and its haunts have been such secluded and unused spots - rarely invaded by man-that it is seldom seen. The residents of sections wherein is the home of the woodcock may never see one from year's end to year's end, and, indeed, may go through life with no more knowledge of them than that derived from hearsay; or, seeing one, may still remain in ignorance of its identity. While the quail, the partridge, the snipe, and other game birds are not unfamiliar to country residents and are readily identified by them, the woodcock and its doings are shrouded in mystery. The large woodpecker in some sections is called woodcock by the country folk, while in other sections any plover which has a long bill is often called by the same name. So little is the bird known, that sometimes when killed it is called snipe, and sometimes the snipe is called woodcock, by those who have not given the bird special study or attention. Its life being so entirely without the sight of man and in general so little being 
known of it, it is not strange that the little accurate knowledge is obscured by the air of much mystery, and that those who seek the bird find a fascination in it greater than that of any other form of game bird shooting. The bird itself is of peculiar form and of rare richness in its colorings, and its flesh is esteemed a morsel of choice excellence fit for the palate of the most fastidious epicure. Thus it affords great sport in its capture and is pleasing to the eye and to the palate.

The scarcity of the bird, its beauty, and the delicate flavor of its flesh, all serve to enhance its value, and its mystic life adds a charm to its pursuit which is distinct from all others.

Its home is generally in densely shaded nooks in out-of-the-way places where man rarely enters and where the soil is soft and moist, for in such places is its food obtained. The alder runs and slopes in the birches and nooks in the woods where springs or rivulets or excessive moisture makes the ground soft, are its favorite haunts, and sometimes in certain sections it finds spots in the cornfields which are desirable feeding grounds, though haunts and feeding grounds are never plentiful. In Mississippi it is occasionally found in open sedge fields. Many places which to the eye have every appearance of being a suitable home for it, still have no birds in them.

The difficulties of woodcock shooting have been greatly exaggerated, particularly as concerns the extraordinary skill required by the shooter, and the still 
more extraordinary labor, and consequent fatigue, imposed on the dogs, the latter being an indispensable factor in the sport if any success worth considering is sought. While intrinsically the sport possesses all the requirements of the highest degree of wing shooting, the writers on it have deemed it fitting that it be dressed in a glamor of romance, presumably that a little knowledge might be presented in an elaboration of high colors which touched on the sky, the sunshine as it glinted through the alders, the beautiful color of the foliage, the balmy zephyrs laden with nature's perfumes, ad infinitum, all of which are present in all other kinds of shooting, or, indeed, present if there is no shooting at all. The shooting of woodcock is difficult, it is true, but not so extraordinary in its difficulty as to be distinctly special, and far from being so difficult as most shooters make it from injudicious selection of guns, loads, etc.

Woodcock shooting is close shooting, the closest of any kind of shooting recognized as legitimate sport with the shotgun. While the woodcock is called a game bird, it is gentle and mild in its habits, with none of the pugnacity or extraordinary vitality possessed by members of the grouse family. The smallest of shot is sufficiently heavy to kill it, and the cylinder-bore gun is amply close enough for the ranges which one must accept in shooting it. The choke bore of any kind is out of place in such extremely short ranges, and unfit to use on a bird so easily killed; though, strange to say, the use of it is not uncommon, 
owing, no doubt, to the fact that many men, owning but one gun, must use it for all kinds of shooting, and in other instances to the further fact of thoughtlessness concerning the proper requirements of the sport. Short barrels, too, are desirable, the difference in the handling of a 30-inch barrel and a 24-inch barrel in cover being far away in favor of the latter.

Woodcock shooting is largely a matter of snap shooting; therefore, a wider range at a much shorter distance is a requisite if one is cultivating success instead of nursing a fad in respect to the use of chokebore guns for all kinds of shooting, whether the guns be fitting or otherwise. In the shooting of quail or chickens or ruffed grouse-to a lesser degree with the latter-a certain degree of deliberation and quick aim can be practiced, but in woodcock shooting the opportunities for deliberation are the rare exception; hence the need of adopting an open gun to meet the requirements of quicker work and short ranges. Light loads and smaller shot can be used successfully, some noted shooters using dust shot exclusively. With a short cylinder-bore gun-a true cylinder bore, not the modified choke bores, which are often called cylinder-such a pattern can be secured at I $5_{5}$ or 20 yards as will insure fair success to the average shot and the best of success to the good one. It might be said that such a gun and load are too murderous, and indeed they would be in the hands of a man who could shoot with any degree of precision if he could exercise deliberation; but as in the greater number of instances 
the shooter has but an instant in which to act, the results are far from being so fatal as one might fancy them to be. Often there is but a momentary glimpse of a dusky shadow flitting through or across a small vista in the dense growth, and the shooter must fire then or not at all, unless he is pleased at a purposeless tumult, that being the sum total when he shoots and trusts to luck for the execution of his purposes.

As in all other shooting, experience enables the sportsman to recognize the promising nooks for woodcock and the signs which denote its presence, these being the holes made by it in boring in the ground for its food, and other indications well known to the shooter, and which can only be recognized by experience.

As to the labor and fatigue imposed on the dog while seeking for woodcock, they are largely an exaggeration. Wilson, in his work on the birds of North America, specifically mentions the fatiguing efforts which the dog encounters in woodcock shooting, and mentions that relays of dogs are necessary. As a matter of fact, the work of the dog in woodcock shooting is the easiest of all kinds of shooting. He must range close to the shooter - at most not beyond a gunshot-if he is to serve the best purpose in that kind of shooting and it is not at all essential or desirable that he work at high speed. It is essential, however, that he be intelligent, and know thoroughly the best manner of working to the gun and assisting the shooter to get his shots in a manner to insure success. He 
should work diligently, but not hurriedly, and it is hardly necessary to add that the work should be done as silently as possible, though this also is true of all other kinds of shooting.

The dog should be a good retriever, otherwise a large percentage of the birds will be lost, for many times it is as difficult to find the bird after it is killed as it is before. Dogs which run riot in this shooting can soon tire themselves out, particularly in summer shooting, when dogs are out of condition, and the weather warm, but the consequent fatigue from such overexertion and unfit condition cannot be justly attributed to the difficulty of the sport. It is rather hard work for the shooter, particularly him of the North, where the quest must be made afoot, and where the footing is difficult and insecure, though after all it is but little more difficult than any other shooting in which the shooter walks.

As the dog often comes to a point in thick cover out of sight of the shooter, even though the point may be but a few steps away from him, a bell attached to the dog's collar has been found of great assistance in determining his whereabouts, and its silence indicates when he stops on point, a matter very essential in conducting the sport. Not every dog is a good woodcock dog, even though he may be excellent on quail, snipe, chickens, etc. Some dogs appear to dislike the work intensely, others refusing to recognize the bird at all. A few take to it very kindly, and work to the gun from observation to a useful degree far above 
what could be established by the most careful training. The spaniel is but little used in the United States for woodcock shooting, or any other kind of shooting, for that matter, though there is no doubt but they could be made eminently useful in field sport.

In Louisiana, and other sections of the South, where the woodcock seeks a clime more genial than that of a northern winter, the conditions of shooting change almost entirely. In sections at certain times, generally in the last of December and the fore part of January, they may be found in great numbers, and a bag of twenty, thirty or forty in a day is not then considered remarkable. They frequent the switch-cane bottoms, or woods in the timbered prairie, in which the heavy fall rains have softened the ground, and where abundance of food can be found. Their stay in the South is very short, for they start North immediately on the lessening of the winter cold-after a stay of not more than a few weeks-their coming and going then being quite as silent and secret as in the North. They are then killed in great numbers, both day and night, by market shooters, and shipped to the home and distant markets. They have their choice feeding grounds even in that land of abundance, and skill, diligent effort and knowledge of habitat are quite as essential to success in the southern winter shooting as in the less bountiful shooting of the North in summer and fall.

So scarce has the woodcock been for the last dozen years that some young gunners have never seen one, and know them only from books. Happily, for the 
past two or three years they seem to have been rapidly increasing, a result, no doubt, of their protection in summer over most of the country.

It is interesting to recall the days of woodcock shooting a generation ago and to compare their results with those of recent times. For the past few years many a gunner who devoted a week or ten days to faithful tramping and shooting in eastern covers has thought himself fortunate if in that time he killed three or four woodcock. An item published in Forest and Stream in 1874 speaks of three gunners who went out early in the summer season and in one day killed sixtyfour woodcock. Twenty, twenty-five and thirty a day were ordinary records for a single gun, and in November, 1876 , we recall an account by a friend of a day's shooting which yielded him twenty-six woodcock besides a less number of partridges and quail. 


\section{SNIPE SHOOTING}

The snipe is notorious as an uncertain bird, and snipe shooting as a sport that can never be depended on. In old times one used to walk mile after mile in the hope that some of the birds might be started from some favorite bit of feeding ground, but too often only disappointment and weary leg muscles rewarded the enthusiastic tramper. On the other hand, snipe were occasionally found in great abundance, and could hardly be driven away. Recollections of occurrences of both kinds are laid away in the memories of all of the older gunners.

Near Vincennes, Ind., many years ago, there was a famous feeding ground for snipe to which, during migration, the birds resorted in great numbers. Thither I went one season with a companion to whom the grounds were well known, and there I saw more snipe than at that time I supposed existed. We were driven to the edge of the marsh, and there, as the team drew up and the wagon cramped to let us jump out, a dozen snipe rose almost under the horses' hoofs, flew fifteen or twenty yards and alighted.

Disregarding the advice of my friend, I had brought a dog with me, the best on partridges that I had ever seen, but he proved absolutely useless here. The birds 
were so many, the scents so numerous and confused, that the poor old dog entirely lost his head and galloped about aimlessly until called in and made to follow at heel. The birds got up, a dozen at a time, flew a few yards ahead and alighted, and then a number of others got up and did the same thing. The report of the gun put a considerable number on the wing, yet at first did not seem to make the birds wild. Meantime I could hear my companion, who had gone off by himself, shooting very regularly, and felt that his greater experience was now standing him in good stead, and that he must be acquitting himself very much better than I was. For the multitude of the birds, and the way in which they were rising on every side, confused and unnerved me almost as much as it did my dog.

Although that day I killed more snipe than ever before or since, yet I do not look upon it as one of the shooting days especially worth remembering. The birds were too many, and I was not in condition to take advantage of my opportunities. I have had more satisfaction from a single ruffed grouse, neatly killed as he darted away through the thick underbrush of the swamp, than I did in that heavy bag of snipe, where I loaded and fired all the afternoon, until my ammunition was exhausted.

Some such feeling as this, I believe, animates most sportsmen when they reach grounds where birds are so numerous that all the uncertainty of shooting is taken away. Few of us, I think, care greatly to catch 
brook trout-strong and gamey though they may beout of a preserved pond.

Something of this sort Mr. Waters expresses in the admirable article on snipe shooting which follows this. He has tramped the marshes where snipe were scarce, and again where, as in Louisiana, they were enormously abundant, and he, better than most gunners, knows the oddities and eccentricities of this remarkable bird.

Mr. Waters' article, with slight changes, says:

According to the writings of ornithologists, the breeding grounds of the snipe begin on their southern boundary, at about 42 degrees of latitude, a parallel through the northern part of Nebraska, Iowa, etc. The grounds extend thence north to the Arctic Circle. The snipe migrate leisurely southward as the winter season approaches, tarrying on the available feeding grounds, ultimately going as far south as the West Indies and northern South America.

It is a bird of the wet lands, and as said of the woodcock, the available area affording its food supply is small as compared with the earth's surface. Relatively, the places which are soft enough to be bored with its sensitive bill, which contain food to its liking, and enough to supply its needs, are exceedingly limited in number and area.

Soft and wet land may also be gravelly or sandy or clayey, and therefore unfit to sustain the animal and vegetable life on which the snipe subsists; or from its refractory nature it may be impervious to the deli- 
cate weapon with which nature has provided the snipe for the capturing of its food. It therefore is apparent that of all the wet lands there are only certain parts which contain snipe food.

Of the places which afford snipe food some are good throughout the whole season, as, for instance, the sloughs and marshes and parts of river valleys of the prairie country wherein it makes its summer home. Other places are but temporarily available, as lands made soft and wet by heavy rains. Such places may serve it well for many weeks, as in Louisiana and Texas in the fall and winter months, during the rainy season, which in those States is largely the equivalent of winter. Again, the snipe may seek its food in places which are quite wet, as in some of the large wet marshes, and again, in some other sections, it may make its haunts on upland so firm that the hunter may walk thereon pleasantly and dry-shod.

While the woodcock, its long-billed confrère, is a bird of the covert, the snipe is a bird of the open. On these birds nature lays a more severe restriction concerning a late stay in the North than she does on any other game bird, for a snipe or woodcock attempting to gain a subsistence in a frozen country is in a pathetic situation indeed.

Its food is said to be larvæ, tender roots of plants, and worms, which it secures by boring, and also such insects and other edible food as it can secure on top of the ground.

To the local sportsman the snipe's habits in the 
shooting season-which is mostly the migratory season-seem erratic and unknowable, if its unstable characteristics may be called habits at all. It is in one place to-day, and to-morrow in another. To-day there may be an abundance, to-morrow a dearth. Or it may go contrary to its erratic reputation and remain a number of days about the same grounds. Still, the shooter is largely in ignorance of what the snipe will do next. The weather and food conditions may be the same, so far as observation can determine them, and yet the birds come and go in their own whimsical way, regardless of conditions. Some subtle, mysterious impulse seems to impel the birds of a certain locality either to come or go, though not in the manner of birds which flock.

Snipe fly mostly in ones or twos or threes, sometimes more, but always in small numbers. Being independent in flight, it is difficult to understand how the common impulse to seek other grounds is at the same time felt and acted on by all the snipe of a certain neighborhood, or at least by most of them. There are many exceptions, as a matter of course; as, for instance, in a section where there are snipe in abundance on a certain day, a part only may leave at the same time. Indeed, a few snipe may be found on certain grounds throughout the whole season. Yet, however much the exception may affect the rule, the greater part of the birds are erratic and lawless most of the time.

No doubt that which seems whimsical and mysteri- 
ous in the life of the snipe is really in harmony with the needs of its nature. As it is nocturnal in habit, it is difficult to study, and it is specially difficult for the resident of one locality to observe its general habits with any degree of precision. Seeing it in but one small corner of its habitat, the local sportsman can gain, at best, but a fragmentary knowledge of its needs and its habits.

Being swift of wing and enduring of flight, the snipe undoubtedly feeds over vast areas of ground many miles apart, twenty or thirty miles of flight being of no more effort to it when in search of food than twenty or thirty rods are to the prairie chicken. When snipe invade feeding grounds in vast numbers, as is frequently the case, the grounds are soon thoroughly bored, and all the food within reach is consumed; thus it may be a necessity for them to seek food elsewhere till the exhausted grounds have time to replenish themselves.

Many writers lay great stress on the difficulties of snipe shooting. They treat it as a bird of phenomenal swiftness and erratic flight, and the shooting of it as requiring something extraordinary in the matter of skill. As a matter of fact, snipe shooting, at certain times, is the easiest of shooting. On warm days, when the birds are fat and lazy, flying slowly and tamely, with pendulous bills, as is often the case in the fall, in the South, no bird a-wing is more easily killed. They are then disinclined to fly. They indolently lie to the dog's points till the shooter walks them up. 


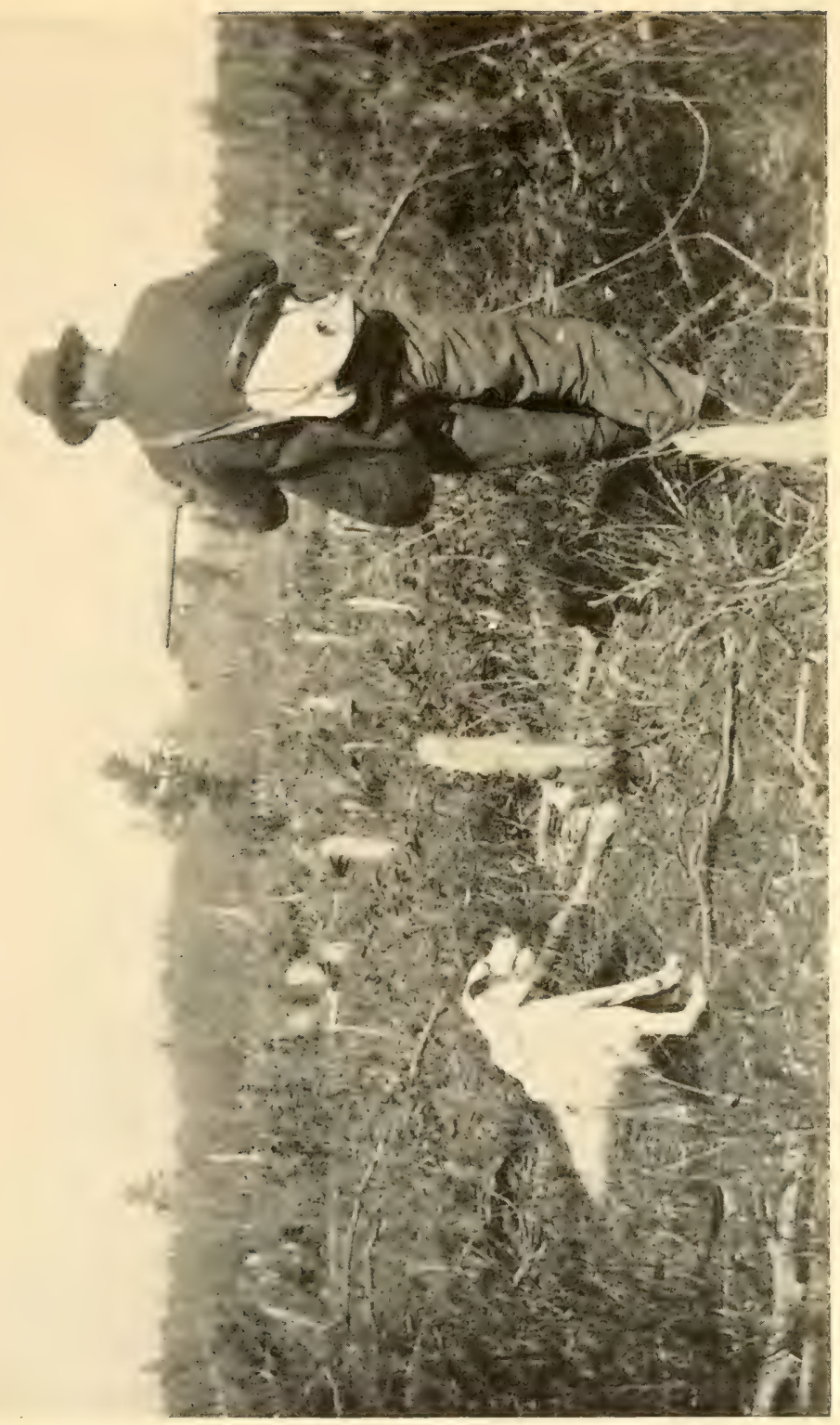

कू 

The books teach that the snipe rises with a zigzag flight against the wind, darting to right and left with such rapid flashes of speed that the best of skilful sportsmen are puzzled, and consequently make many a miss.

The snipe, it is true, goes against the wind when there is a wind, and zigzags a few times to rise upward before taking a straight course. Many writers on snipe shooting lay it down as correct that the shooter, to take advantage of this peculiarity in rising, should walk down wind, or advance to the dog's point down wind, so that when the snipe is flushed it will fly toward him. All such teachings savor of the novice, or of a skill which needs nursing. All the difficulties are greatly exaggerated, zigzag, swift flight and all. The zigzag of the snipe a-wing is in the beginning of its flight, and nothing is easier than to wait a moment till it straightens out on a straight flight. Then the killing is a matter of shooting on the wing, similar to other wing shooting.

As to walking down wind to secure a better shot, the sportsman need not concern himself about it in the least, excepting perhaps on such days as are cold, and days when the birds are very wild and rise at the extreme range of the gun. As with pigeon shooting, the really good shot does not let his birds get far if they rise within range. Whether they zigzag or not, he snaps them as soon as they are on the wing; or being well on the wing, he permits them to get into steady flight, and then delivers his fire. There is on 
the part of the experienced shot no particular attempt to reach the bird from a weak quarter. He takes the shooting as it comes.

On windy days, or when the weather is cold, the snipe may be very wild and rise at extreme ranges. Shooting then is quite as much a test of the gun as it is a test of the shooter's skill. Few writers, however, pay any heed to the distinction, and consider it all, be the rise far or near, as a matter of skill alone. At best, walking down wind on snipe is an uncertain advantage, for they can fly down or across wind with a swiftness and ease which dispose very quickly of any trifling advantage of a few yards taken up wind for the start.

The habits of snipe, as oftenest described, are their habits when they are lean and wild, or wild from a change from warm to cold or from calm to windy weather. But to teach that such is their regular manner of flight would be on a par with teaching that quail live in the tree-tops because they sometimes take refuge there.

Even when lean and wild, on a calm day the snipe does not strain the skill of a good shot. But on a windy day it is a different proposition. The wild, lean snipe can dart very swiftly across or down wind, and if to this be added rise at long range, the shooting becomes really difficult, though then, as mentioned before, it is also a test of the gun.

When wildest, the snipe is exceedingly restless and moves fitfully from place to place. It then takes alarm 
quickly, flying high out of range, with its bill extended straight ahead. It can pitch to the ground from its highest flight, darting downward with stiffened wings and alighting with the greatest ease.

In the course of migration the birds stop in favorite places where food is abundant, and oftentimes there remain till the weather becomes unpleasant. As a rule, they arrive in the South in a lean condition. When lean they are also wilder, regardless of weather conditions.

Shooting then, if limited to times when they are wild, is shooting in its most difficult phases. But as mentioned before, such difficulties of snipe shooting are not the average of snipe shooting.

Snipe shooting as to possible quantity varies widely, one locality with another. One locality may contain but a few snipe to reward the shooter's efforts, while in other nearby localities they may fairly swarm, as in Louisiana and Texas in the fall and spring months, when the birds are migrating. In those States they generally remain several weeks to enjoy the food abundance. Some scattered ones in the South may be found all through the winter. The heavy rains of fall and spring, frequently a downpour of days in the far South, soften the fat alluvial prairie lands, thereby fitting hundreds of square miles for the snipe's habitat. In particularly favorable sections of the prairie, cotton, corn and sugar fields, they may at times be found in thousands. A dog in such shooting is an encumbrance, except to act as a retriever. There is no woodcraft 
necessary in such shooting. The sportsman walks along till the birds are walked up. So rapidly will he sometimes flush them that at every step it is fire and load, and fire and load again. At such times the gun becomes too hot to hold, and the shooter must perforce stop till it is cool enough to handle.

Enormous bags of snipe have been made, particularly in Louisiana and Texas, where the greater part of the flight of North America congregates for a few weeks in the period of snipe migration. One of the greatest, and I believe that it is referred to now as the greatest bag, was made many years ago by Mr. Pringle, a wealthy sugar planter, of Louisiana, who had great fame as a sportsman of rare skill. He bagged 400 and some odd snipe in one day. This is a large bag, indeed. It is but one of thousands of large bags in that section, so common as to excite no special comment.

I have told of these matters to shooters in the North whose success was measured by a dozen snipe, more or less, as the result of a day's shooting. Such large bags being outside of their personal experience, they have been pleased to consider it an idle tale. They seemed to think that their narrow experience in shooting a few birds over a few acres of ground each year was the measure of the world over.

In regard to the big bag made by Mr. Pringle, it may be added, by way of explanation, that he had negroes to assist him, some to carry the spare guns, others to carry the ammunition and to retrieve the dead 
birds. I have been told by men who have hunted with him that he is a most indefatigable walker, and possesses extraordinary quickness and accuracy in the use of the shotgun, snapping the birds almost on the instant that they take wing.

In that land of game abundance, at that day, it was not considered unsportsmanlike to kill all that the sportsman pleased to kill, for however great the bags, there was no apparent diminution in the numbers of the birds. If the sportsmen killed many, their neighbors derived the benefit of it. The killing, too, was at irregular intervals, differing from the steady drain made on the bird supply day after day by those who shoot for market.

This circumstance of the record bag was a happening of many years ago, when the sentiment concerning game preservation was different everywhere, North and South, from what it is to-day.

As to snipe shooting, and the way of it, the proper manner to shoot them is to go forth and shoot them. In other words, the set manner of doing this thing and that thing, as taught by some writers, is all very well if one can do no better.

There is no rule whereby snipe shooting can be made soft and easy, and there is no sportsman with proper ambition who will care to have his skill less than the best test that the bird can offer. If the sportsman's skill is equal to the test, practice will improve it. In any event, there is at least the pleasure of trying to cope with the conditions. The proper skill is 
that which takes the shooting as it comes, instead of picking out the easy shots, or easy combinations to secure them.

The best snipe gun is moderately choked, or an improved cylinder bore. As in all open shooting, good work may be done with a full choke, since the shooter can pick his distance to shoot his birds. However, it is not every man who can wait on his bird, or who can estimate distances at a glance; therefore, it is better to have a scatter gun which will be available for instant use when the bird rises. A I2-bore is most commonly used, and as for the size of shot, No. 8 s or 9s or Ios are good, the latter being quite large enough when the birds are fat and lazy.

As a bird to shoot over dogs, the snipe is inferior. Sometimes it is in such abundance that a dog is unnecessary. At other times it is so wild that it will not lie to the dog at all. If fat and tame, it may lie too well. Again, it will frequent marshes so wet, cold and rank with marsh grasses that it is impossible for a dog to work satisfactorily, however good his intentions and ability may be.

Very few dogs have a natural fondness for work on snipe. It is acquired in most instances. Some dogs, good on upland game birds, thoroughly detest the snipe and refuse to recognize it. On the other hand, some dogs like snipe as a bird to work on, though such are exceptional.

Considered strictly as a bird of the open, the snipe affords excellent open shooting. Yet there is never 
the weird uncertainty about it that some writers have discovered. No doubt an easy explanation of the difficult shooting is found in the manner in which the shooter handles his gun rather than in the manner of the snipe's flight.

When snipe are in great abundance, and can be bagged with little effort by walking them up, the sportsman soon tires of the sport. It is too easy then to be considered sport. On the other hand, when they are scarce, wild, and will not lie to a dog, it is too difficult and uncertain. The dog is eliminated then as a factor, and the shooting is largely a matter of taking chances. When the happy medium is found, the birds being neither too wild nor too tame, it is excellent sport indeed, though in Louisiana I noted that where there was an abundance of both snipe and quail the sportsman quickly tired of snipe shooting and gave quail the preference. 


\section{QUAIL SHOOTING.}

The quails of America cover a greater territory than any other of our game birds, and are more faithfully pursued than any. They are found, interruptedly, from points in Canada far down into Central America, and beyond. Over the eastern half of the continent, and far better known than any other species, bobwhite stands alone. Moreover, by one means or another, he has extended his range, first to the Rocky Mountains and then beyond that to the Pacific coast, while the Texas form, and some Mexican species, drift far to the southward.

Bobwhite has been called the game bird of America, and from early days has furnished sport to northerner and to southerner alike. It was never abundant in Canada, though the gunners of southwestern Ontario used to get a few; but forty or fifty years ago it was very abundant in central New York, from which country, we believe, it has long been exterminated. Many years ago the late Prof. O. C. Marsh, of Yale College, used to relate with gusto stories of the good quail shooting that he had had near Lockport, N. Y., in the days before the Civil War.

Hard winters and overshooting have long ago almost exterminated the quail in Massachusetts, Connecticut, New York, and portions of Pennsylvania, yet 
it cannot be doubted that self-control on the part of gunners would result in the re-establishing of these birds in goodly numbers through many sections of their former range. In a certain Connecticut town, where the quail had been practically exterminated, the gunners, for several years, have had an understanding that no one of them should disturb these birds. The result of this protection has been that in the spring of I9ro quail might be heard calling from every side in certain sections of this town. It is said by the gumners there that there will be great quail shooting this fall. This may mean that the gunners will again kill off all the quail, and that again for six or seven years they will have no shooting.

In the West are the beautiful plumed and helmeted quails of the mountain, of the valley and of the desert -and those other birds of curious plumage and soft, thick crest, Mearns' quail and the scaled quail, also known, respectively, as "fool quail" and "cotton-head."

Except for Mearns' quail, these western forms do not, we are usually told, offer good shooting. They run like deer before the dogs, rise at long distances, make long flights, and as soon as they reach the ground start running again. Mearns' quail is said to be an exception to this rule, and lies close and hard. So difficult are valley quail to shoot over points, that many gunners of southern California do not attempt to use a dog to find them, while others use dogs only for retrieving, or to flush the birds while running. Few people in the United States have had greater 
experience in quail shooting than Mr. B. Waters, who has written one of the very best articles on this subject that has ever been penned, which in substance reads as follows:

\section{BOBWHITE SHOOTING.}

From the personal point of view, each one generally has his own preference in respect to the bird which he prefers to shoot to secure the greatest pleasure, and this preference in turn determines the shooter's opinion that such bird is therefore the best of all birds for the purpose of sport. Thus, one prefers ducks, and not considering that his own personal idiosyncrasies, or greater success, or habit and long association, or what not, may have much to do with his preference, he solemnly affirms that duck shooting is the best of all shooting. And so with him whose choice of sport is the shooting of some other bird-that bird is sure to be exalted above all others.

But from the standpoint of the greatest good to the greatest number, quail shooting, for many reasons, is the best of all shooting. It is a kind which affords such mixed shooting-open and cover, slow and swift - that shots can be found to meet the skill and fancy of all, be the former little or great and the latter fastidious.

There is much of the open quail shooting which is not so difficult as to dishearten him of moderate skill, while, on the other hand, shooting in cover tests the 
skill of the most expert sportsman. And again, taken all in all, whether in open or cover, the quail shooter of good average skill can compass a good showing in results, and thus enjoy the pleasure which comes from reasonable success.

In this connection it may not be amiss to maintain that a certain degree of success is essential to the shooter's pleasure. Many writers deprecate the consideration of the bag, treating it as an irrelevant, gross incident, so dominated by the beauties of nature and the ethics of shooting, in the abstract, that it should be mentioned in hushed tones or viewed with eyes askance. The beautiful and the useful of sport should go hand in hand. Each is a part of the great whole, and as such should be equal factors of sportsmanship. To the sentimental, which ennobles and adorns the useful of life, there must be added the material and the practical. To the shooter there must be a reward for his efforts. It has often been said that it is not all of shooting to shoot, nor all of fishing to fish, forgetting the converse, that, all of shooting or fishing being absent, there is no shooting nor fishing at all.

As to quail shooting in respect to quantity, there is more of it than there is of any other kind of shooting, hence each shooter can better satisfy his longings for sport if it be measured by the possibilities of the bag or the number of opportunities offered. And there is also more of it when measured by the matter of time, for it extends through a season of about five months, taking it as it is in the North and South. 
Thus, the man whose business cares leave him but a few days for shooting, and these at no definite time, has more possibilities of sport on quail than on any other bird.

But the very abundance of the quail seems to have checked the proper appreciation of it. Not that it is treated with neglect, but there seems to be a lack of the enthusiasm and lavish use of the superlative, so often to be noted when writers are discoursing on the ruffed grouse or the woodcock. Nevertheless, it is not uncommon to have a keen relish for what is rare, even if it be not of the best, while the good may be so common as to escape notice.

The quail is more uniformly and widely distributed throughout the United States than is any other game bird. Its habitat generally comprises both open and cover, though whole districts are exceptions, as will be touched on later; thus, besides giving the sportsman a mixed style of shooting, is added the charm of constant variety, and testing of the sportsman's skill in woodcraft. It differs from the ruffed grouse, whose home is in the woods, a much smaller section relatively.

All works on natural history, so far as I know, teach that the quail's home comprises conjointly both open and cover; and while this is true in a general way, there are important exceptions to it, so much so that a work devoted to the habits and habitat of the quail as they are in one locality might be distinctly erroneous if applied to the quail of some other locality. In this respect it differs from the prairie chicken and the ruffed 
grouse-for of the one it may be said, without qualification, that it is a bird of the prairie; of the other, that it is a bird of the woods. Such sayings of them will be found to be true wherever those birds may be found.

The quail thrives wherever it can obtain a food supply, in open or in cover. It readily adjusts its habits to the dominating circumstances of food and cover, whether it be in prairie or woods, or a country comprising both open and cover.

In the country north of the Ohio and east of the Mississippi River, it frequents the open fields largely, preferring such as have a good food supply, with hedges or old walls and fences fringed with brush, or nearby woods and thickets to which it can run or fly for shelter or safety. In such sections it rarely goes far into the woods, preferring to skirt around the outer edges of them, merely for protection and shelter. The hawks are its deadly enemies, and it needs ever to be alert in avoiding them.

The quail oftenest roosts in the open fields, where there is at least a few inches growth of grass, stubble or weeds for concealment, and it uses the same place many times if not constantly disturbed. This is indicated by the grass or other vegetation being beaten down in the roost, a small circular opening, about two feet in diameter, and the pile of droppings in the center of it.

The birds huddle on the ground, bunched up close in a circular form, with their heads outside; thus all 
face toward the outer circumference of the circle, which cannot be approached without coming to the view of some bird. This arrangement is said to prove admirable for the safety of the whole. In theory it seems a wise arrangement; in practice it works very badly, since they often fly reluctantly when they have comfortably adjusted themselves for a night's rest. The pointer or setter may also draw very close to them then, generally doing it with greater precision than when they are more scattered about, the evening hours being more favorable for strong scent and accurate pursuit. Were not dogs trained to such stanchness as is required in shooting, they could easily, at such juncture, spring in and capture, as indeed some partially trained dogs will do under the circumstances.

In the States of greatest bird abundance, as in Arkansas, Mississippi, etc., and where there are many ragweed fields, very destructive shooting often takes place near the twilight hours, when the birds have settled themselves for their slumbers. When the dog points the bevy the shooter places himself at the proper distance from the roost to obtain the best scatter of the shot. Then the huddled birds, being flushed, swarm up loosely together for three or four feet, when the shooter takes a snap shot at them, and often does nearly as much damage as if he had potted them on the ground. It is hardly necessary to add that this practice is disapproved by all true sportsmen.

In Minnesota, Dakota, Nebraska, Kansas, and other prairie States, the quail readily adapts itself to the 
local peculiarities of the different sections, utilizing such slight advantages as may offer, as hedges, fences, the cover with which most streams are fringed, or high weeds.

The quail sadly needs cover for its protection, its destroyers being both of air and earth-hawks, foxes, cats, dogs-and the eggs, too, fall a prey to the rapacious appetites of some of its enemies. In the South the cur dogs of the negroes-every family owning one or more, all kept in a kind of half-famished conditionprowl through the fields seeking for food; they are the very worst of egg destroyers. Were the quail not so hardy and prolific, its fate would be swift, and extermination certain.

The negroes' dogs seem to be almost omnivorous. In the fall they may be seen making daily visits to some persimmon tree, under which they eat the fallen fruit with apparent relish. Those which have some claim to hound blood are not averse to making a meal in the corn field, on corn when it is in the milky stage. With such rapacious enemies to contend against, the destruction of the quail must be great, but in addition to all that, many are trapped and netted, methods which destroy whole bevies at a time.

But to return to the matter of the quail's habitat: in certain parts of the South, as in the oak woods in sections of Alabama, Texas, Arkansas, or in the pine woods of Louisiana, Mississippi, etc., the quail may live wholly in the woods, food, always a first consideration, being there secured in abundance. 
In cover, some of the shooting is easy and some of it very difficult, though hardly ranking in difficulty with ruffed grouse shooting. The quail is neither so wary nor so wild as the ruffed grouse. Shooting in some parts of the pine woods is almost as easy shooting as shooting in the open, the ground being bare except for its covering of dry pine needles. The smooth trunks of the pine trees, standing several yards apart, and free from limbs for thirty or forty feet. offer no serious obstacle to the shooting. In other sections of the pine woods, where the growth of the trees is more stunted, and the limbs grow from near the ground up, the difficulty of the shooting is second to none, and in some sections is almost prohibitive.

Again, there are sections wherein the quails live on the open prairie, as in parts of Arkansas, and, the shooting being strictly open, it much resembles chicken shooting, excepting the difference in the size and speed of the two bircls, the quail being much the quicker to get away at the start. The quail makes its flight in the open prairie, alighting near any little bit of shrubbery, be it no more than a bush or two of sumach, which, by the way, grows here and there on the prairie in Arkansas. In the woods, when pursued, it frequently takes to the tree-tops for safety, where it is hidden indeed. On warm days, or when there has been a long spell of pleasant weather, it is far less wild than when the weather has been stormy, or when there has been a sudden change from warm to cold. Such changes add to the difficulty of the shooting. 


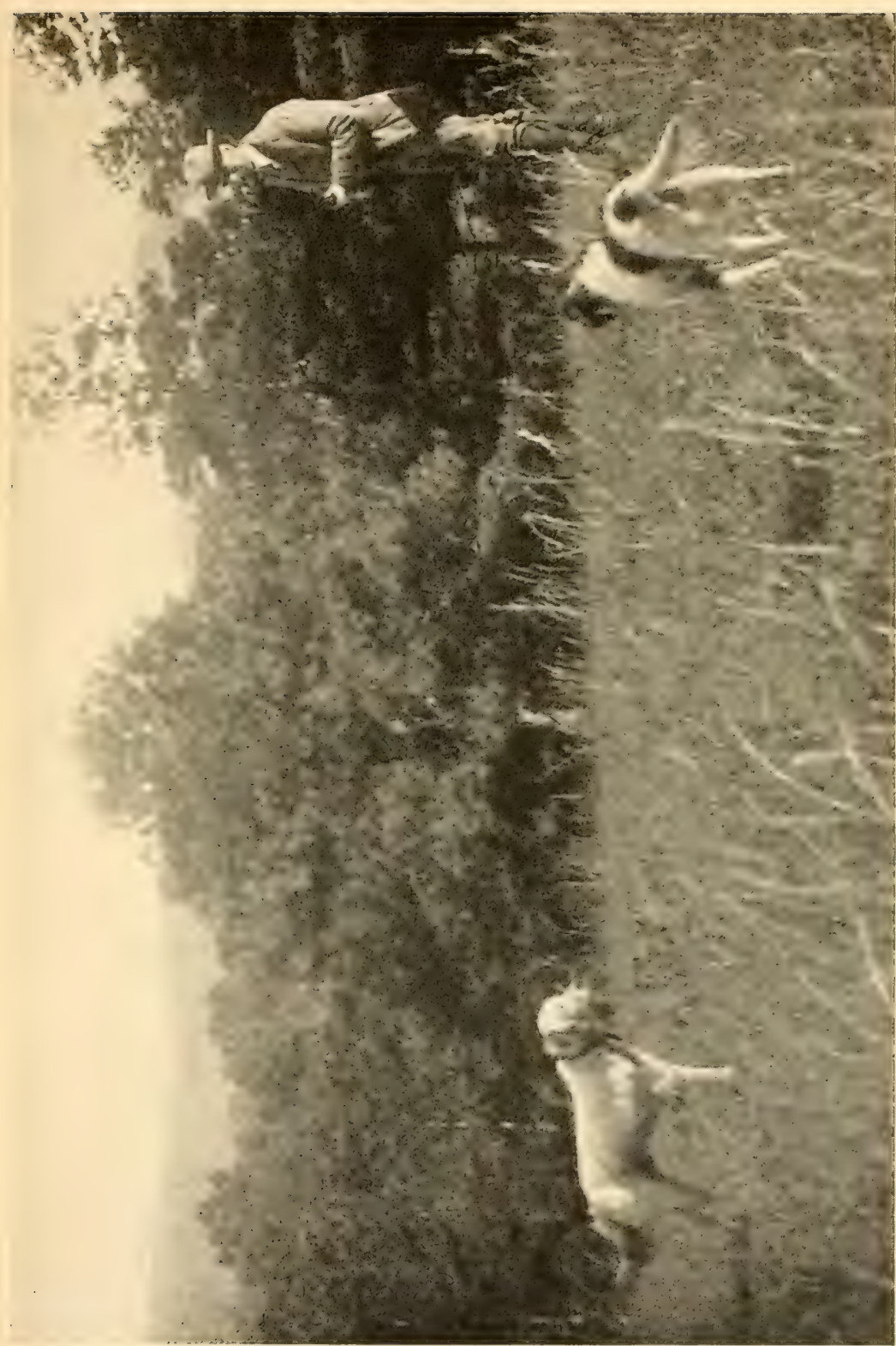

苛
몽 

In the North, the quail makes its home where some buckwheat or other grain field is available for a food supply. It so arranges its haunts that it has some cover within easy flight, in the densest part of which it seeks safety when flushed, not refusing the heavily timbered swamps if too much persecuted by the shooter. In such places it has an excellent chance of escape from pursuit, or may foil its pursuer by simply running away; or, if pressed to take flight, it has many chances for safety owing to the difficulty of shooting accurately in the dense cover.

New England shooting is the most difficult of all quail shooting, excepting, perhaps, shooting in the dense pines and cat briers of the South. Then, to have any satisfactory success, the scattered birds must be diligently followed and sought in the thickets, be they ever so dense. In this respect it differs from shooting in the sections of more abundance, where such close attention to the scattered birds is unnecessary, either for sport or the interest of the bag.

In the South, where there is an abundance of birds, comparatively, the sportsman rarely tarries with a bevy which gives him any special difficulty. It is much easier, and more satisfactory, to go on and seek more birds. For this reason, even under favorable opportunities, the scattered birds are never, as a rule, hunted till the last one is flushed, and flushed again, when it is possible, as in the North.

In New England, buckwheat fields are the quails' choicest resorts for food, and any adjacent brush, or 
long grass of swamp or upland, or the skirts of woods, afford the shelter and protection that they need or seek. No doubt the birds become wilder in the North than in the South, for, first of all, the inclement weather of the North tends to make them so, and there is a much more relentless pursuit of them by the shooter. The birds being scarce, after the bevy is scattered the search continues while there is a hope of finding a single remaining one; and if success with them has been unsatisfactory, the shooter may return later to catch them, when they are whistling to each other in the attempt to come together as a bevy.

In the broad plantations of Mississippi, Alabama, Tennessee, Arkansas, etc., a dog of reasonably wide range is necessary, much wider than would be either desirable or useful in New England, or similar sections in respect to cover; for there is much of the country in the South, open and cover, which everywhere affords a bountiful food supply, and, therefore, the birds are to be found in the most unexpected places. The cover and cultivated fields of the South do not aid the hunter's judgment as to quail haunts to the degree that they do in New England shooting. In the latter place there are comparatively few areas in which the birds can get both food and cover together, or even food alone, and the sportsman soon learns to distinguish the favorable places. In the South, in cover and open, there is food in abundance everywhere. There are vast fields, some of which are overgrown with sedge grass, others with weeds, with fields of 
cotton and corn interspersed, any part of which is a fit habitat for the birds; thus, the dog working out such ground in the South can, as a rule, beat out all parts of it with probable success. In the more open grounds of the South the dog can be seen at long distances, so that a wide range is not detrimental in itself, providing that the dog is really working to the gun, and not self-hunting or semi-hunting.

As to the manner in which the dog should hunt, no hard and fast rule can be laid down which would apply to all sections.

Whatever may be the quail's abiding place, it learns to make the most of its surroundings in promoting its own safety and interests. It learns whether it is better to fly or run in evading its pursuer, and the best strategy to attain that end. If good cover is conveniently near, it may trust to its wings at once for safety, and to its legs and wings if followed into the cover.

If the country is open, or with narrow and insufficient cover, as in parts of Louisiana, and other sections where the ground is thoroughly cultivated, it takes a great deal to its legs and cunning devices. In working on such birds the dog must learn to govern his work by the circumstances of it. He might be an excellent performer on quail in the North, and a poor one in the South, or he might be a good one in Mississippi and a poor one in Louisiana, though the presumption is that if he were good in one section he would become so in any other section after the necessary experience. 
Many of the plantations of Louisiana are drained by open ditches running parallel at reasonably equal distances from each other, though the distances may vary greatly one field with another and may be 50 or 200 yards, more or less, apart, while other ditches of like arrangement intersect them at right angles; thus a plantation may be cut with more or less regularity into small squares surrounded by ditches. Some plantations may be irregularly ditched, while others with a far greater watershed may not be ditched at all. The heavy rains round out the banks of the ditches and their bottoms, and a fringe of weeds and brush, thick and thin in places, strings along the banks and makes a fairly good shelter for the quail. On these land squares are grown cotton, or corn, or nothing, as the case may be, though, if not cultivated, there is always certain to be a good crop of weeds, affording plenty of quail food. When flushed in such places the quail may fly a few yards to the first ditch, or may cross over two or three ditches before finding a place to its liking.

As mentioned elsewhere, the state of the weather may greatly affect the quail's habits. The bevy having gone to the ditches for safety, the dog, to be useful, must have great superiority in roading if he pursues satisfactorily. When in the ditch the birds run swiftly along the bottom. It is almost impossible, at first, to induce the green dog to go into the ditch, or, being in, it is impossible to make him remain there, though it may not be over a foot deep, and dry. The green dog 


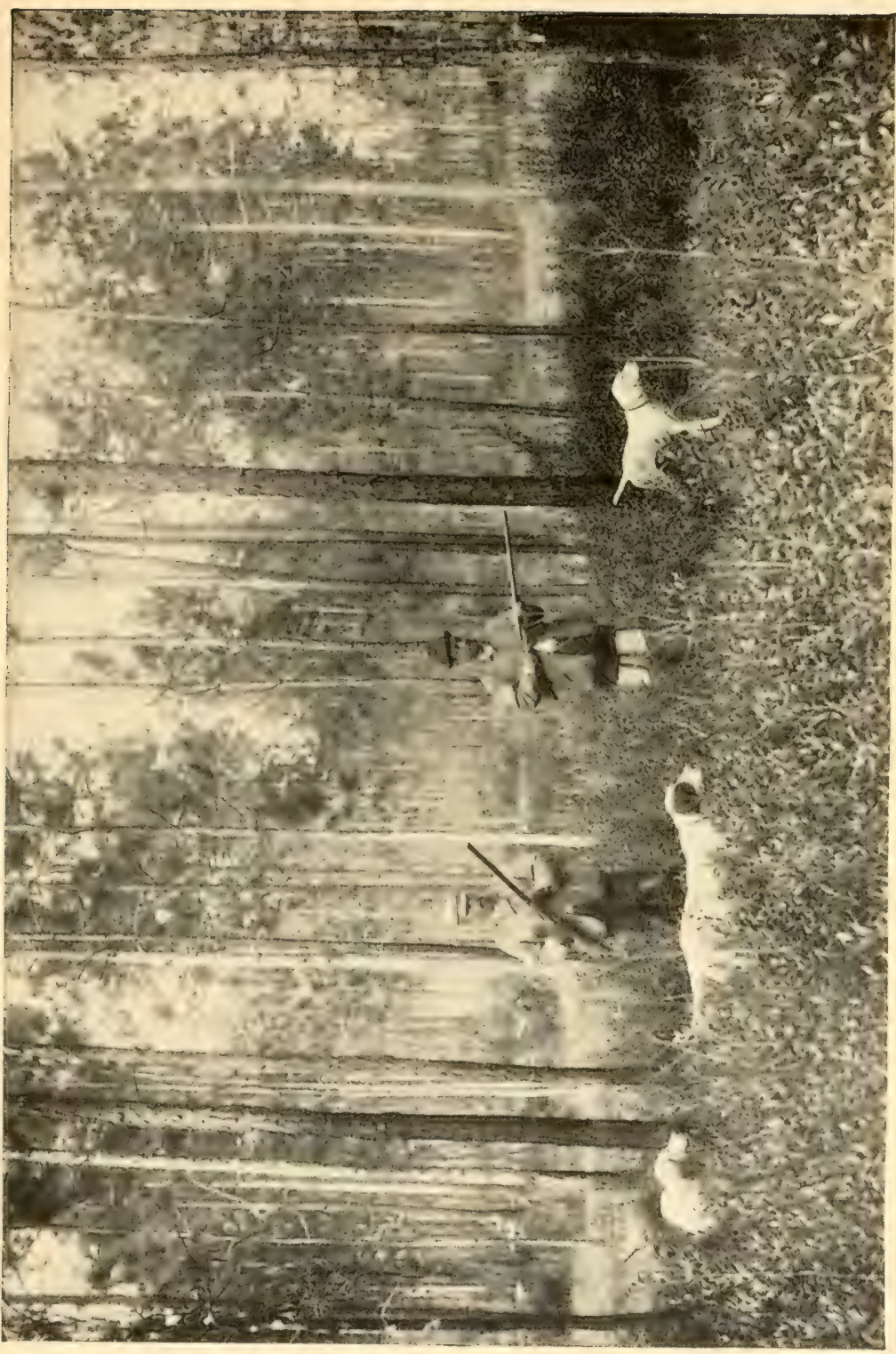



will promptly cross out from one side to the other, missing the scent, and accomplishing nothing useful. He does not know what is required of him. But once he catches the idea, he soon improves on it, following carefully along the bottom of the ditch and pointing the scattered birds here and there, every few yards apart, in ones and twos, the shooter having a good opportunity from his position on the outside to kill as the birds fly out.

The shooting along ditches is not so easy as one might imagine. Sometimes the birds run swiftly several hundred yards or more in the ditch, and may then run out and across to other ditches, giving a trail which may try the most experienced dogs to follow.

If the birds happen to be near a cotton or corn field, where the ground is bare, and there are no ditches for concealment, they may run so fast and far that the dog may never approach near enough to them to secure a point, and the shooter who is inexperienced in this work will be likely to think that his dog is surely deceiving him.

When near the woods, or switch-cane, the birds often take shelter therein, and when in the latter cover it is well to abandon further pursuit of them.

In the sugar country, where there may be corn fields here and there among the broad levels of the sugarcane, the character of the shooting again changes. Many birds will be found in and around the corn fields, and then it is very pretty shooting.

It may not be amiss to mention, for the benefit of 
those who shoot in the sugar country for the first time, that they should keep their dogs out of sugar-cane fields as much as possible. The cane, in harvesting, is cut diagonally across with a knife, thus leaving a stump with an edge which will cut a dog's foot almost as a knife would. It is a common matter for a dog to split his toes or heel on cane stumps, with the resultant crippled condition, and no more work from him for a time.

In Mississippi, in the midwinter season, the birds stay mostly in the woods. Good shooting may be had in the South from the middle of November to the first of March. Many of the Southern States have a longer legal open season, but the dense cover and warm weather make a natural limitation to the sport. The weather is mild, the birds are strong, and the sport is at its best, in the winter months of the South.

Quail shooting, in the main, is close shooting, as to the ranges at which the birds are killed. Most birds drop within twenty-five yards, some much nearer than that.

A gun weighing from $6 \frac{T}{2}$ to $7 / 2$ pounds is of ample weight. The I2-bore is most commonly used, though the 16 and 20-bores are excellent, and are preferred by many sportsmen. Some shooters use guns of 28 caliber, and are enthusiastic over their work. As a matter of course, the smaller bores may be much lighter than the I2-bore.

The I6 and 20-bores being smaller, their killing circle is less, though they shoot with good force in 
comparison with the I2-bore. Closer holding is required to shoot them well. Whichever bore is used, it should not be closely choked. There is no need of a choke bore in quail shooting.

It is an extremely difficult matter to induce the average shooter to use an improved cylinder-bore gun. The recommendation to use an open bore seems to be construed as reflecting on his ability to shoot a close gun, instead of being accepted as sound information concerning the gun fit for that particular kind of game. It requires time to effect a reformation concerning the use of the choke bores in quail shooting. The sportsman should go forth equipped for his sport according to his needs, and not to the whimsicalities of senseless fashion. He should not take a full-choked gun in cover, nor a cylinder-bore gun to shoot ducks. There should be intelligent adjustment of means to ends. Industry and skill and woodcraft should not be balked by visionary theories and inappropriate weapons.

The foregoing is written of the quail as it refers to man's pleasure afield with dog and gun. Naturally it is not fearful of man, and rather prefers to dwell near his haunts, not from an affection for him, but from the fact that near cultivated sections there is always more food to be found than in the uncultivated. The matter of providing food for itself and its young is quite as constant and insistent in the life of the quail as it is in the life of man.

It often nests in or near the cultivated field. Its cheery, ventriloquial whistle, reiterating its favorite 
utterance, bobwhite, may be heard about the farms, particularly in the morning hours, and bobwhite has come into use to designate the bird itself. Sometimes the call is uttered with a short introductory note, and these, with a few alarm calls, or calls of inquiry when the birds have become scattered, seem to be about all the vocal means of communication which these birds have.

In many parts of the South, where the quail are in greater abundance, their sweet notes may be heard in many directions, at many distances, in the early morning and evening hours. These calls work great harm to it, for by them the shooter learns the whereabouts of all the birds in his neighborhood, and locates the haunts of every bevy. "In the fall, the rallying cry often serves to inform the sportsman as to the best course for the morning's hunt. In the South the quail is called partridge.

In the fall, when the shooting opens, the quail soon learns of the gunning dangers, and its habits thereupon change quickly to conform to a life of greater safety, though it will run many risks to be near an abundance of food. However, when danger is impending, it avoids the open much more than when danger is not, and is more alert, quicker to suspect mankind, and quicker to take alarm.

When spring returns, the quail seem to lose their fears of man, and they breed with little reference to concealment from him. Their confidence is unimpaired 
till fall approaches, when there is a repetition of all the fears and troubles and dangers of preceding years.

He who can average three kills out of six shots, cover and open, is an excellent marksman. The shooter may make a run of ten or twenty straight kills, but soon there are sure to come misses if he does not pick his shots. In winter the shooting is much more difficult than in the fall. Of course, the man who never misses is of the parlor, not of the field.

The home of the greater number of the American quails of the extreme southwest or on the Pacific coast is in a country of great aridity. Moreover, much of the vegetation of that country consists of thorny and spiny plants, of which many are cactus, yucca or mesquite. It is evident that over much of this country the use of dogs in shooting these birds would be difficult, if not impracticable. For much of the year the ground is so dry that no scent would lie, and a dog, unless trained for that particular work, would be at a great disadvantage. Moreover, in the swift traveling performed by hunting dogs, as they are trained in the South for field trial work, a dog, in a very short time, would inevitably become crippled by the spines of the cactus, which he could not help constantly running over or into. If to these difficulties we add the fact that the quails seldom or never lie to a dog, but run as hard as they can at the first intimation of danger, endeavoring to get into the thick brush, through which they can thread their way faster than any animal can 
follow them, it will be seen that many of these quail cannot be pursued for sport, as sport is commonly understood; that is to say, the shooting of a game bird over a pointing dog. This a priori conclusion is confirmed by statements made by sportsmen who have lived for many years in Arizona, one of whom, Mr. Herbert Brown, not only a sportsman, but a field naturalist of great ability, tells me that he has never heard of a dog being used on Gambel's partridge in all the time he has lived in the southwest. Yet Allen Kelly says that in the irrigated districts of the Imperial Valley, Cal., Gambel's quail lies well where there is cover, but on the bare ground runs like a deer.

I have seen the valley quail in southern California and the mountain quail in the Sierras, but have never yet seen either hunted with dogs. That the mountain quail can be shot over dogs is hardly to be doubted, but the case is different with the valley quail living in the lowlands of dry California. On the other hand, in Vancouver Island the introduced valley quail sometimes lies to a dog among the thick undergrowth, much as the eastern quail would lie. When startled they get up in a thick coveys of fifteen or twenty birds and scatter and sometimes lie well.

\section{VALLEY QUAIL.}

Of the California valley quail in the vicinity of Pasadena, N. P. Leach says on this point: "Up here on the mesas and among the sage brush and grease- 
wood in the foothills we use dogs when hunting quail, chiefly for flushing and retrieving, but down on the plains, amid the cactus and low brush, some hunters use both setters and pointers. There, when you flush a covey of quail and shoot in among them or over them, they will very often scatter and then hide under the cactus and lie to point. It is a cruel place to work a dog. The first day that I took my dog down there, he filled his shoulders and breast full of cactus spines. We pulled out most of them, but even then he was in no condition to work for some days.

"Over one-half of the quail hunters here do not use a dog, and ninety per cent. of the other half use spaniels for retrieving. The other small minority use either setters or pointers.

"When my spaniel flushes a covey, some of them fly my way, so that I am very sure of a double shot, and sometimes an extra double at some of the laggards. Then, as the dog can outrun the birds, he keeps them moving, which often gives me shots at fast-flying birds. I have him so trained that I can control him with my whistle; that is, bring him into heel, where he will remain until I tell him to go."

It is hardly to be doubted that if either the valley, the mountain, or, in fact, Gambel's quail, were to be introduced in any section where the climate was mild enough, they would, if properly protected, do well and increase. The beautiful valley quail readily adapts itself to confinement, becomes not at all shy, and has been frequently known to build its nest and lay its 
eggs. We do not know that any have been reared, but no doubt this might readily enough be done, were proper care exercised.

\section{GAMBEL'S QUAIL}

Dr. Coues, in an article in the Ibis many years ago, said of the shooting of this bird in its home:

"Compared with the eastern quail (O. virginianus), from the sportsman's standpoint, Gambel's plumed quail is more difficult to kill. Not that it rises with more startling suddenness, or flies faster, for I noticed no material differences in these respects; but when a bevy is flushed, and one, or at most two, birds secured, it is exceedingly difficult, and usually only by chance, that other shots are obtained; for except under certain circumstances, they lie very badly, and when they drop after being for the first time started it is, usually, not to squat and remain hidden, but to run as fast and far as possible; so that, if found at all, it will be dozens of yards from where they were marked down. This propensity to run, which is also a great obstacle to their being flushed within proper distance, is exceedingly troublesome both to the sportsman and his dog; so much so, that the best trained dogs can often be of little or no service. It is true that this habit of running affords many shots on the ground, and often places the whole bevy directly under fire, but no true sportsman would thus ingloriously fill his bag by potting a bevy of such noble game birds. Like all their tribe, 
their flight is exceedingly rapid and vigorous, but it is always even and direct, so that it only requires a very quick hand and eye, and the usual intuitive calculation for cross shots, to kill them readily. Notwithstanding all I have heard to the contrary, I consider them far from being tough birds, and No. 8 shot is abundantly large enough for them. The fault in most cases, I presume, is with the shooter rather than the shot. I may add that many of the places in which bevies are found would compare unfavorably with the worst woodcock brake of the Eastern States as regards facilities for obtaining a fair shot. I have had a bevy flushed all around me and hardly caught a glimpse of a feather. But these, and all other difficulties, should only increase one's ardor and confer additional value on the lovely birds when obtained.'

\section{MOUNTAIN QUAIL.}

In the California Mountains, near various hill towns, the mountain quail are often abundant, and late in October, or early in November, after rain, or snows turning to rain, we have occasionally started coveys which, flying for no great distance, would pitch down and lie so close that they could be walked up by a gunner and a few good shots had. In such situations, and at a time when the ground was moist enough to make the scent lie well, I should expect to have good shooting with a careful dog.

In the dry West, however, conditions for shooting 
differ so widely from those which prevail in the more humid East that it will probably take a long time for gunners and dogs to work out a system, at once agreeable and effective, for shooting these game birds.

Dr. Elliot declares that many are shot over dogs, but that far more are trapped and netted.

The situation is still more difficult when birds of the extremely dry country of Arizona and New Mexico are in question, though, as will be seen further on, Mearns' quail appears in quite a different category.

SCALED QUAIL.

Of his attempts to shoot the scaled, or blue quail, Dr. Coues says :

"This species is a bird of noticeably terrestrial habits, rarely taking to trees or bushes unless hard pressed in one of those extremities into which some people are fond of forcing any birds large enough to be worth a charge of shot, and wary enough to make it exciting sport to penetrate their poor bodies with it. It generally trusts to its legs rather than its wings, though these are not at all deficient in size or strength. On level ground it glicles along with marvelous celerity, and makes good progress over the most rocky and difficult places. As a consequence, it is rather difficult to shoot fairly, though it may be 'potted' in great style by one so disposed; and it will probably require several generations in training before it can be taught to lie well to a dog. I am inclined to think, indeed, 
that the lying of quail, an essential feature for the chase in its perfection, is almost as much a result of education, as the 'pointing' that the intelligent brute who helps us kill them has learned. In a primitive and strictly natural condition, quail, as a general rule, rather use their legs to escape pursuit than squat and attempt to hide. That the reverse is the case with the Virginia quail, I am perfectly aware, but this proves nothing to the contrary, and I am inclined to think its crouching, till almost trodden upon, to be an acquired trick. This would surely be a poor way of escape from any of its natural enemies-any carnivorous bird or mammal; yet they find it to succeed so well against their chief persecutor, that he has had to call in the aid of a sharper-sighted, sharper-nosed brute than himself, else he might stumble over stubble-fields all day without seeing a bird, except by accident. I presume that Virginia quail in the days of Captain Smith and Pocahontas were very much in the social status of the Arizonian to-day; and these certainly trust to their legs and wings rather than to the artifice of thrusting their heads in tufts of grass and then fancying they are safe."

Dr. D. G. Elliott, a sportsman of long experience, has this to say about the habits of the blue quail when pursued :

"This bird runs with great speed and seems to be able to keep it up for a long distance, and flies with much reluctance, alighting almost immediately and heginning to run at once. When compelled to take wing, 
it rises with the usual whir-r-r, and proceeds on a slightly curved line, rather straight ahead, and if, on alighting, it should stop for a moment, it is almost at once under the cover of some cactus or other low bush, which affords a place of concealment; and from which it can watch its pursuer, before starting to run again.

"A dog is practically useless for hunting the scaled partridge, for if he is well broken and attempts to point a covey, the birds will run several hundred yards, while he is standing, and then will add several hundred more while he is trailing them, and the poor animal becomes bewildered and disgusted and is apt to run also. I know nothing so trying to the patience of a sportsman as the tactics of this species, unless it be the similar habits of other crested quail. As a rule, this species was not very much hunted in the localities I met with it, and it always seemed to me rather singular that they should be so wary, for that is an attribute that wild creatures usually acquire, after having made the acquaintance of man and learned that his presence always brought wounds and death, and that safety to themselves was only to be obtained by leaving his vicinity as soon as possible. But these birds seem instinctively to have ascertained this fact before they ever saw a human being, and decamp at once whenever a man appears." 


\section{MEARNS' QUAIL.}

With Mearns' quail the case is quite different. This bird, while not at all shy, possesses markedly swift flight, and lies exceedingly close.

Dr. L. C. Frick, who has had much experience in shooting them in New Mexico, considers them a better game bird than bobwhite. In shooting them he uses pointer dogs, which have proved very efficient. Dr. Frick believes that if this bird could be introduced into the Mississippi Valley and the country east of it, it would at once become enormously popular as a game bird. He mentions as a great point in favor of this species, that when the birds rise the sexes can always be distinguished, and that therefore cocks may be selected for killing and the hens preserved. He believes that the males greatly exceed the females in number, and that therefore it is practicable to do a good deal of shooting without lessening the productive power of the birds in a particular district. The eggs are given by Captain Bendire as eight or ten in number, but, on the other hand, Mr. Nelson, who has been much in the range of these birds, says:

"I have never seen the Massena partridge in coveys larger than would be attributed to a pair of adults with a small brood of young. Frequently a pair raise but three or four, and I do not remember having ever seen more than six or seven of these birds in a covey."

Mearns' quail is odd in appearance and odd in habits, but one of its chief peculiarities seems to be that in 
a country where all the quail take to their heels and run like race-horses, it alone, when it pitches down, lies hard, and will let the dogs get up close to it before flushing. We do not understand that the birds are particularly hard to hit. Though they fly swiftly, the shooting is usually open, and only reasonable quickness is required to hit the bird. 


\title{
SHOOTING THE WOODS GROUSE.
}

\author{
RUFFED GROUSE SHOOTING.
}

Dwelling in many sorts of country, sometimes, as in the East, where it is constantly pursued, cunning to the last degree, and practicing every stratagem; or again, in the wild regions, dreading only its natural enemies, and thus fearless and bold, and trusting wholly to strength of wing, the ruffed grouse is killed in many ways and under varying conditions. Where it is ignorant of firearms or of the danger from man, it permits half a dozen shots to be fired at it at close range, or sometimes may even be noosed from its perch on a limb by a bit of string tied to the end of a pole.

A graphic account of ruffed grouse shooting in a region where they had been little disturbed, yet were not wholly tame, was contributed to Forest and Stream many years ago by that charming writer and good sportsman, Mr. T. S. Van Dyke. In those days ruffed grouse were abundant in the region referred to, as, in fact, they have been up to comparatively recent times in that country, as well as in certain sections of Michigan, where, within only a few years, we have heard of from twenty-five to thirty birds being killed in a day by two guns. We give the substance of Mr. Van Dyke's account as follows: 
Who that has heard the somber shades of the dense pine forest throb beneath the strokes of his hoarse resounding wing, or in the autumn woods has seen him flash for an instant amid the hues of crimson and gold, or pierce like a shaft of light the dark green of the cat-brier swamp, can ever forget the ruffed grouse? What sportsman can forget the feelings with which he has heard his drum-beat echo from the dark mountain side, or through the bursting woods of spring, or in those soft, still autumn days when the leaves are falling through the mellow haze of Indian summer, or, as sometimes heard, in the noon of night, in the depths of the forest primeval? Few pictures hang more bright in the inner chamber of the sportsman's soul than the broad fanlike tail spread along his path as he treads the trail of the deer, or its dark bands shining on the carpet of checkered leaves or sweeping over the mossy carpet of wintergreen or vanishing in the heavy green of the laurel brake.

Not even the majestic woodcock, with his solemn dignity; not bobwhite, with his sweet, graceful ways and artless beauty; not the brilliant but erratic little genius of the boggy meadow; not the noble turkey, with his beamy bronze and bearded breast, can raise such tender memories as this grouse. For all these must be sought, and often sought in vain, in their native haunts. But the ruffed grouse is a more familiar spirit, and many a time plays across the sportsman's path when wandering over the sapling-clad slope where the autumn woodcock lies in the full bloom 


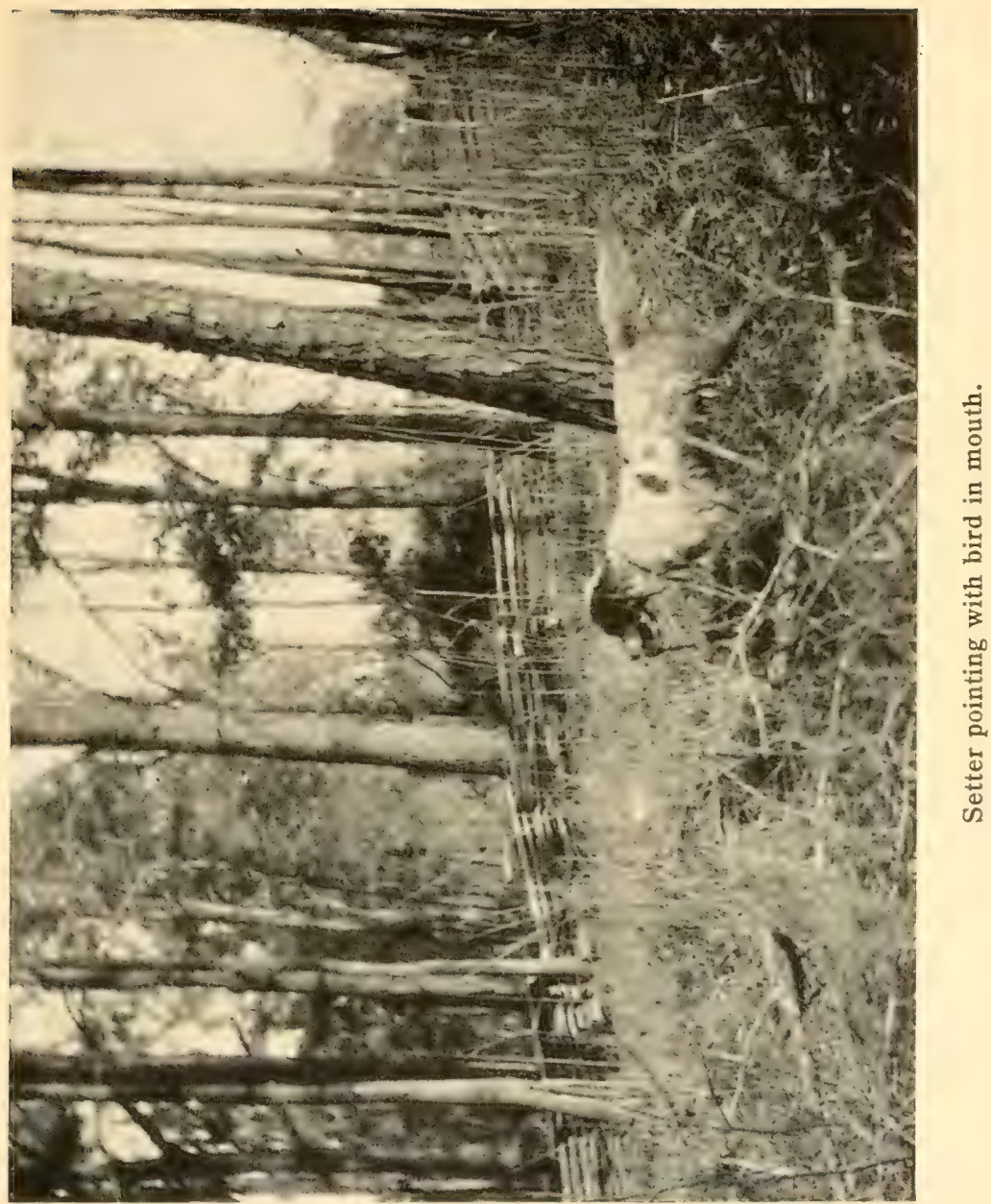



of life and fatness, or when following bobwhite through the hazel thicket, or when roaming from pond to pond in search of ducks among the vine-clad arbors of the river bottom. And often the hunter of the deer sees him strut before him as he sits resting on a fallen $\log$, and often, when on the trail of the deer in winter, sees him shake the snow from his lightning wings, as, bursting from its cover, the bird goes whizzing away amid the snow-draped trees.

Few of those who most love this noble bird have ever seen him in the simplicity of youth, before he has left his mother's side and gone forth to roam alone the spangled shades of the rugged mountain side or the somber shrubbery of the tangled glen. For his hearthstone is too often in the dense mass of summer's wealth, and few are the eyes that can follow him into the deep, dark brake or into the shaggy covering of the mountain's breast, until autumn's frosts have tattered their gay banners and trailed their green glory in the dust.

For certainty of finding this grouse at home in his early days, with comfort in hunting him, few places have ever equaled the bluff regions of the upper Mississippi. Here this grouse lived and lovecl, and stayed until long after the autumn leaves were scattered on a thousand winds; and even after the deep snows of winter fell upon his early playground many a one remained instead of seeking the covers of the bottom lands. Here he may be found while the trees stand in the full green of summer and before any hue of 
death has touched their shining heads. Years ago these bluffs were studded from base to crest with large oak trees, scattered more or less along the slopes, and more abundant and dense of foliage around the sides and heads of the numerous ravines. Where they happened to fall, the rich verdure of the white birch generally filled their places, and in the bottoms of the ravines and along the base of the slopes the crab-apple and wild plum and scrub oak formed abundant cover. Everywhere along the hills the ground below the trees was densely carpeted with green, upon which the sunlight flittered in a thousand shades through the openings in the leaves above. And yet the walking was always good, and the view generally free in all directions beneath.

It was one of the fairest days in 1867 that, with a friend and two dogs, I first roamed these pleasant shades and found my old friend in a new kind of home. From nearly the foot of the bluffs, where the outer guard of soft maple and white-oak saplings began to encroach on the black oak of the hills, to very near the top, where the birch was flying its bright green flag from its snowy staff, the dogs were soon racing to and fro, while we were strolling along behind them, half way up the hillside. We soon came to a shallow ravine where the ferns and the prairie grass that covered the ground were taller and greener, and the shade of the black oak and maple was deeper and cooler than on the rest of the hillside. The elder dog, named Jack, had hunted such ground before and 
seemed to know all about such places, and at once started up the leeward side of the ravine with slow and cautious trot, while the younger, named Frank, seemed to have an intuition that the other dog knew more than he did, and slowed down his pace to about the same. And soon Jack's trot subsided to a walk as his nose caught the faint breeze that played over the shady side of the hollow, and his tail slackened its lashing motion and settled down to a slow wavy swing. Quietly he moved along, with nose upraised just above the deep green of the ferns and prairie grass and the bright golden hue of the lady-slippers and the carmine of the wild peas, raising it from time to time still higher, with inquiring sniff, and swinging steadily off to the leeward so as to keep the breeze fairly in his nose all the time. And soon the old dog's tail began to straighten and the joints of his legs to stiffen, and he turned his head slowly from side to side, and snuffed the air more cautiously as he moved, more and more slowly, along. And all the time Frank coming up the other slope, some hundred yards away, with eyes fixed intently upon Jack, imitating all his movements, even more strongly than if he had smelt something himself, instead of taking Jack's word for it.

Suddenly Jack stops, and as suddenly Frank does the same, and at the same instant a line of mingled white, black and gray, with roaring wings enveloping the whole in a haze of brown, bursts from the rank ferns some ten yards ahead of the dog and darts like an arrow through the green arcade. 
Bang-whang go two barrels of the guns almost together, a feather parts from the long, outspread fan behind the booming wings, and in a second more the brown streak fades among the distant trees.

$B-b-b-b-b$ goes another from almost the same place, almost before the first one is out of sight, and bang goes one barrel of each gun exactly together, and a cloud of feathers floats from the downward whirling bird, while with boisterous $b-b-b-b-b$ seven or eight more birds rise, curling, flashing, darting and whizzing from the ferns in all directions.

But Jack seems to have no anxiety about the birds that have fallen, and after going cautiously a few steps forward, stops again, with slowly waving tail. Carefully he moves along, sniffing daintily at the air on high, and swinging off occasionally to one side so as to catch the full breeze, then, as he advances a few paces beyond where the other birds had risen, his limbs and tail gradually stiffen, until he again becomes quite rigid, with Frank, on the other side of the ravine, imitating all his motions almost as accurately as if the two were connected by an electric wire.

As we come up to him he suddenly relaxes, moves off a few yards to one side again, and then, with nose high upraised and body sunk low in the grass, he crawls forward a few feet, in shape more like an alligator than a dog, and then comes again to a standstill. As we advance a little in front of the dog three grouse burst roaring from the ferns some twenty feet ahead of us and dart away in different directions. One 
whirls downward out of a cloud of feathers; another changes his course at the report of another gun, and mounts skyward through the tree-tops; the third, dashing the sunshine from his glistening wings, scuds away through an open place, with the guns belching flame and smoke vainly at the place he had just left; while the one that had mounted above the trees, poising for a second aloft, closes his wings and descends with a heavy thump to the earth.

The fallen birds retrieved, we went on to find the scattered birds. Some three hundred yards we wandered along, and suddenly Frank began to dawdle in his pace. With gently oscillating tail, he sniffed inquisitively at the breeze that swept up the hillside from the long ravine below. To our senses it was laden with the fragrance of ferns and wild buckwheat and wild peas and white clover, with wild rose and mint; but the dog smelt something more, for he suddenly stopped with the quickness of thought, and at the same instant a grouse broke, with uproarious wing, from the deep green cover, some fifteen feet from his nose. Two charges of shot shivered the blended white and green of the birch behind which he disappeared, the air throbbed no more beneath the beat of his hoarse wings, and a faint nebula of fine feathers drifted into sight on one side of the tree.

$\mathrm{Up}$ and down the hill again both dogs were soon beating the ground. In about five minutes Jack, coming down the hill on a gentle canter, dropped into the grass as suddenly as if shot, and lay there with only 
the tip of his nose visible above the ferns. As we came to him a bird rose like a rocket, only a yard from the dog, and whizzed upward as if bound for the stars. My friend's first barrel decimated the banded feathers of its broad, outspread tail, and he caught it with his second barrel as it was speeding its bobtailed career high among the branches of the old oak trees. As it fell, another bustled, with riotous hubbub, almost from the same spot from which the last one rose, and wheeling, with its breast, mottled with black and white, in full view, cleft the breeze so fast that the shot from my gun was held back by the resistance of the air waves. At least that was my theory then, and it ought to suffice at this lapse of time.

Some ten minutes passed away, and we found Frank anchored apparently to a stump in a little ravine far up the hillside, with Jack indorsing his draft on our confidence with his most statuesque attitude, about thirty yards behind him. The birch was waving in the breeze above him, and the ferns were swaying gently below his nose, the raspberries and blackberries were still bright on the bushes in the ravine, and the young oaks were as green as in the spring, but other signs of life there were none. We threw stones in ahead of the dog, but nothing moved. We tried to urge the dog to flush them, but he would not budge. At the risk of losing a shot I went in, for the ravine was deep and steep-sided. A few feet ahead of the dog I slipped and fell, and in a twinkling the sky above me seemed alive with roaring wings and meteors 
of white and black and brown mixed in a whirl that made the air tremble even more than the thunder of my companion's gun, which was spouting flame and smoke above my head. When I recovered myself I found that four birds had made all the uproar, and that my friend had pacified two of them.

The grouse were so scattered that it was better to search for a new flock than to try to find the single birds that had flown far up and down the hillsides. So we moved along several hundred yards until we came to a broad-bottomed ravine. Along the hills near its head the oaks stood larger and closer than before, the ferns were brighter, longer and greener, the birches were taller, and maples and aspens were jostling them aside. A soft fragrance of wild honey and thyme haunted the dark, cool shades, and everything hinted strongly of the favorite home of the ruffed grouse.

Old Jack at once took the hint, and with gingerly tread went marching up the bottom of the ravine, with nose aloft and slowly undulating tail. Though he had yet smelt nothing, the spirit of the place whispered grouse so strongly that his fancy kept him on a half point from the start, just as many a good old dog's imagination makes him change his pace the instant he enters a dark, damp swamp, where everything breathes the magic word, woodcock. And even Frank seemed enthralled by the cool, green, silent shades, and threaded the birchen bowers and the beds of fern with more than usual care.

But Jack went far up the hill several times, and came 
trudging back, looking somewhat dispirited; and Frank, after making his way as often up and down through the ferns, seemed as badly muddled; yet both seemed to think there must be game there. We passed around the head of the ravine, over ground that seemed especially made for grouse to spend the day in, but they seemed to have that provoking trait that game often exhibits, of ignoring the fine places you pick out for it and preferring to make its own selection. Further down the ravine, below where the scrub oaks and maples and aspens broke into the heavier black oak that robed most of the hills, and where the bottom widened out into a little valley, lay a long thicket of crab-apple and wild plum, edged with black haw and hazel where it broke into the oak and maple of the hills. Knowing that the birds ranged low as well as high, along these hills, we went to it. The dogs soon disappeared within the dense green shrubbery, and naught was heard of them in a minute or more but the light rustle of their feet. And not another minute seemed to pass away before that, too, ceased.

Leaving my friend on the outside, where he would be able to get a shot at anything that came out, I went into the thicket. There stood Jack, bent like a bow, with tail and jowl nearly parallel, as he had evidently thrown himself with a sudden whirl, upon striking the scent from one side. And a few yards behind him, half hidden in the deep green, stood Frank, with the solemnity of a tombstone on a winter night. As I stopped behind Jack there was a bewildering burst of 
uproarious wings, and a dozen or more birds went darking through the green, some wheeling out of the top, some scudding straight away, some darting low toward the edges. Quick as a flash I dropped on one knee and sent a charge through the leaves where one's fanlike tail was vanishing on a sharp curve as I raised the gun. But by the time the shot reached there it was gone, and by the time I discovered it was gone the rest were all gone. But dimly through an opening I could see my friend on the hillside, with half a dozen grouse swiftly driving toward him. One went past him like an arrow feathered with white and brown, and was gone before he could raise his gun. Another, whirling into sight above the brush, with its full white breast, broadly mottled with black, brightly flashing in the sun, just a trifle too late for me to shoot at, went spinning by him with unruffled feathers at the report of his gun. And then five or six more went roaring on past, and above and behind him, while he, in confusion, shifting his gun from one side to the other, and hardly knowing what to shoot at, let them all go by, and stood as if looking for more to come.

Few American sportsmen have had so much experience in upland shooting as Mr. B. Waters, whose excursions have covered the game fields of almost the whole United States east of the Rocky Mountains. Famous as a handler of hunting dogs, and equally famous as a crack shot, both at the traps and in the field, his views on the shooting of any game bird will receive respectful attention, for he is past master of the art. 
This is what he has to say about ruffed grouse shooting:

From the time when the mind of man runneth not to the contrary in matters of shooting for sport, the ruffed grouse, by common consent, has been classed with the most difficult of game birds which the sportsman endeavors to bring to bag under the approved conditions of sportsmanship, if indeed it be not the most difficult of all. For it taxes the sportsman's nerve, patience, skill, woodcraft and endurance as no other bird can tax them; and all these requirements are necessarily supplemented by a gun of good killing powers, one selected with special reference to cover shooting; and last, but not least, a dog of more than ordinary intelligence and good intent and good training, if the sport is to have any successful results and pleasing finish in its action. If any element of the sportsman's ruffed grouse craft be missing success is marred accordingly.

The ruffed grouse, in every art and article, is a bird to fill the sportsman's ideal. Its habitat is in nature's most picturesque setting; the bird is beatiful in its delicate tracings and markings, and rich and varied in its colorings; racy of form and faultless in symmetry; wild, dashing, daring, alert, and infinitely resourceful in its crafty devices when pursued; exclusive in its habits, and, withal, a bird of rare excellence for the table, its flesh being of a delicate texture and pleasing flavor-so palatable, indeed, that it is by many epicures more highly prized than is the flesh of any 
other game bird. With those who may vaunt the excellence of the woodcock, the snipe, the prairie chicken, the duck, the turkey, etc., it also holds a high place in their esteem; and the exceptional man, whose fancy for one particular kind of bird prejudices him against all others, will not speak unkindly of it. And yet, delicious as it is when properly prepared for the table, it can easily be spoiled by ill cooking, and of bad cooks there is no end. The art of cooking it properly is as rare as is the skill of killing it properly. If it be cooked too much, or if it be cooked improperly, it loses much of its rich delicacy of flavor and texture, and becomes dry and unpalatable; and in that unfortunate condition it probably was when that eminent authority, Wilson, partook of it, and thereafter, in his "American Ornithology," wrote of it: "At these inclement seasons, however, they are generally lean and dry, an'd, indeed, at all times their flesh is far inferior to that of the quail or of the pinnated grouse." Yet, as tastes are not all alike, the superlative will probalsly be placed according to the individual fancy in matters of food, as in all other matters, and it is well that it is so. If all fancied alike, all would be monotony. Nevertheless, a man who cannot have a culinary spell cast over him by a skilfully coolied ruffed grouse, it having been kept a proper length of time after killing-not too longhas no music in his soul, and may not even be fit for treason and spoils.

The ruffed grouse chooses rough and timbered sections, for it is strictly a lird of the woods and thick- 
ets, preferring the roughest parts of a hilly or mountainous country, and of these it many times selects the densest recesses, or the timber of seamy and rocky hillsides, or where ledges, fallen tree-trunks and treetops in the woods, secluded from man, guard against intrusion, and even the timbered swamps are not obnoxious to it.

For man it has the most uncompromising aversion. It selects its home in the places least frequented by him, though once the home is determined on it holds to it with dauntless persistency, let the gunner disturb it as often as he may.

In choosing its habitat it prefers that it be near a supply of good water and an abundance of good food, for it is a good feeder. Whortleberries, blackberries, beechnuts, acorns, chestnuts, partrilge berries and buds are readily accepted as food in their proper season.

The bud of the laurel is said to render the flesh poisonous for food purposes, though the belief seems to rest more on tradition than on any direct evidence.

Unlike the quail, which prefers to make its home near the homes of man, and the prairie chicken, which sticks closely to the grain field, the ruffed grouse is ever intent on choosing its home and haunts distinctly apart from those of man. In the East it is called "partridge"; in sections of Pennsylvania and the South, "pheasant."

In the breeding season, when it has been free from pursuit and harassing alarms, it sometimes strays a short distance from cover into the adjacent fields, 
where grow palatable huckleberries and blackberries, though rarely venturing further than a short flight, and often but a few yards from cover.

Though always a wary bird, and ever avoiding man, it is not so wild and quick to take wing before the frost and unsettled weather of fall set in as it is afterward; yet if the gunner disturb it once or twice, the full wildness of its nature, and its constant alertness to avoid man, are fully and permanently aroused. Then man and the places he frequents are shunned as much as possible. Indeed, it is not a social bird with its own kind. After the young birds have matured they separate, and in the fall the gunner will find them in ones and twos, and at rare times in threes.

Given to the sportsman the conditions of an open field, and therein a ruffed grouse on the wing, within range, then the difficulties of killing it are but little, if any, greater than those which obtain in the killing of a prairie chicken on the open prairie; though whether in open or cover, the ruffed grouse is always swift and decisive in its flight. But in the open, whether it be on field or prairie, there is an even light and an unobstructed view. Then, for safety, the bird can rely only on its swiftness of wing, all too slow when pitted against the sportsman who can, under those circumstances, with studied quickness and deliberation, command a large circle around him. Thus the ruffed grouse is at a fatal disadvantage when shot at in the open field, as is also every other bird pursued under the same conditions; but these conditions are rare in- 
deed in ruffed grouse shooting, for, as mentioned before, it ventures into the open only on such infrequent occasions as it is tempted to search therein for food, and then only in places seldom invaded by man, where it fancies there is freedom from pursuit. To all fixed habits there seems to be an exception for a short period in the fall, when it is subject to a crazy waywardness.

While in the open field it is strong and swift of wing, in cover it is at its best. It will, on occasion, dash through the densest thickets with apparent ease, with no diminution of its swiftest speed, seemingly having a charmed manner of flying through tree-tops and thickets as if they were but phantom trees of the woodland, or shadows offering no obstruction to its onward flight.

And in its favorite haunts it is a master of selfdefense. It can utilize thickets, trees, old fences, ledges, stone walls, swift wings and endless cunning to evade its pursuer. Be the position of the shooter what it may in reference to this bird in cover, it, when flushed, takes instant advantage of the nearest thicket or the trunk of a tree or old fence, keeping one or the other between itself and the gumner in its line of flight, thus in a great measure blocking all opportunity to shoot, or at least hampering the shooter greatly, and oftentimes causing a miss.

The bird, in most instances, times its rise so as to have the advantage of some nearby object as a shield to its flight. On occasion it will display a courage 
bordering on audacity, permitting the shooter to pass close by, and flushing after he is some yards further onward. This wile is oftenest practiced after it has been flushed, marked down and pursued. Both man and $\operatorname{dog}$ are apt to pass it then, though they may follow in the exact line of flight. The shooter may hear the irritating roar of the bird's wings behind him, on ground but a moment before passed over, or catch a shadowy glimpse as it dashes away from some treetop.

Owing to its short flights and its proneness to take a straight, or nearly straight line, the persistent shooter may be able to mark and flush the bird again and again. It sometimes, in repeated flights, returns to near the place where it was first found, and it always takes the flights so that ground and cover are to its advantage in avoiding danger.

Once in a while a foolish bird will be found, which will do the very thing it ought not to do, commonly paying for the lapse with its life; so that if there is anything in the theory of heredity, the ruffed grouse should be uniformly of high capabilities, the fool birds being killed promptly, and never breeding.

By far the greater part of the shooting is at close range, as it needs must be in thicket or woods, where the longest views are short, and obstructed by trees or ledges or the undergrowth or the hilly nature of the ground, where in the early season the view may not be greater than a few yards or feet, if the leaves have not fallen. 
It then is not an infrequent occurrence that the shooter will hear the startling whir of wings close by him, and yet be unable to shoot or to mark the bird's course, from inability to see the bird at all. The light of the woods, broken and broken again, as it is through the irregular openings in the tree-tops, and branches and leaves interposing, with here and there shafts of clear light, and masses of shadows interspersed everywhere, tends to interfere with quick and clear vision, and adds to the difficulty of accurate shooting, thus differing widely from shooting in the open.

The successful ruffed grouse shooter must be ever promptly ready to shoot, and further, must be quick of eye and action. He must instantly decide on the manner of making the shot, taking advantage of all the few opportunities offered, and avoiding the obstructions which interpose. No studied effort at aiming is possible. Cover shooting of all kinds requires quick action, but ruffed grouse shooting requires the quickest. Of all snap shooting, ruffed grouse shooting is the snappiest, and the successful shooter of that bird must excel in that kind of shooting, since in most cases he will have but a brief instant's glimpse of the bird in the unfavorable mixed lights of shadows and cover.

For this shooting the gun should be light, short of barrel-26 to 28 inches - and a cylinder bore, for a full choked barrel is entirely out of place in such cover shooting, equally unsatisfactory when it does or does 


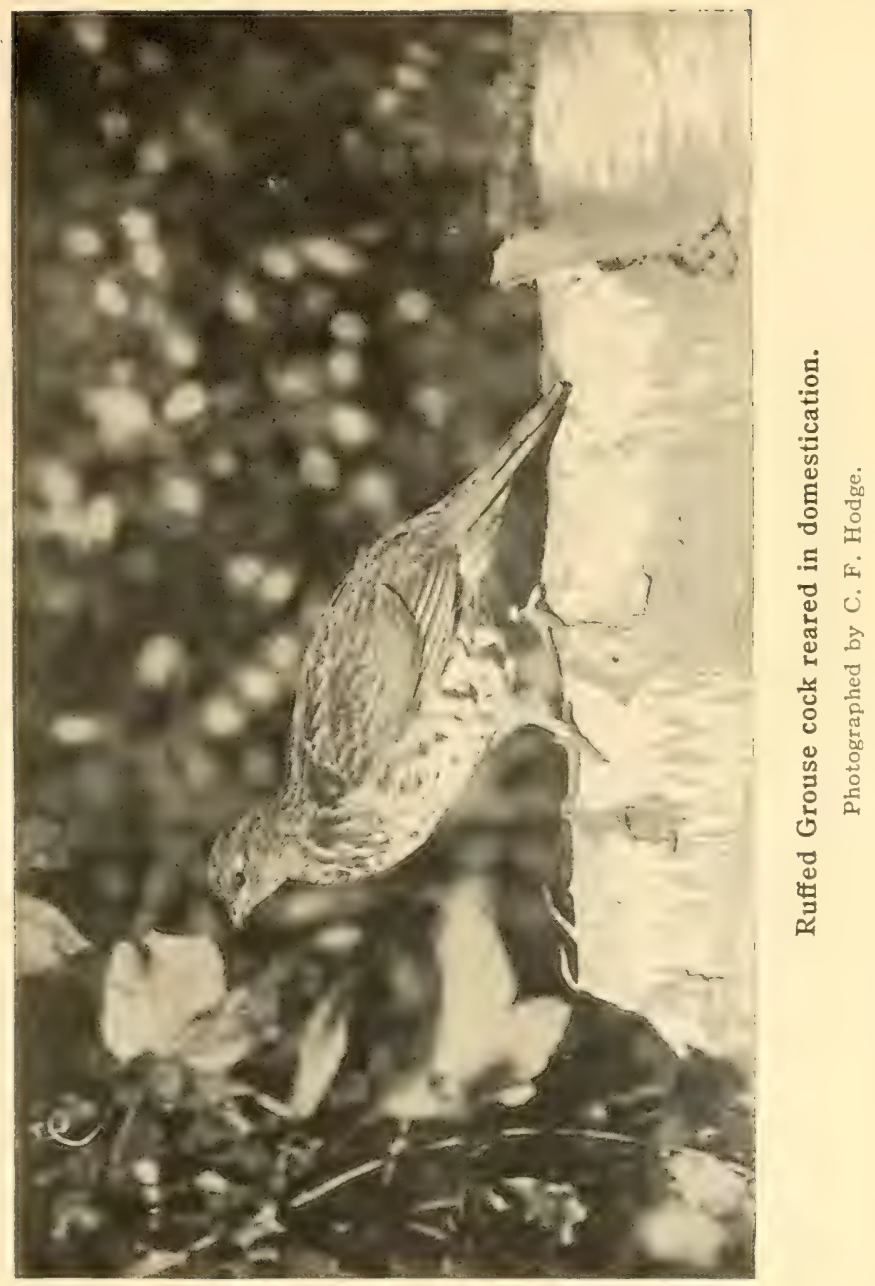



not kill, it being a miss in the first instance, and often a badly mutilated bird in the second.

The average shooter will find that he has success far below his opportunities, even when equipped with the gun most fitting for the work. In this shooting there is no waiting for opportunities to fit the gun.

The successful hunter must take the shots that are offered, and as they are offered; it matters not how difficult they appear or how brief the opportunities may be. He may catch but a momentary glimpse of the bird as it crosses some diminutive opening, or he may see it for an instant in a maze of leaves and branches, or he may get a partial glimpse of it and some disturbed leaves in the course of its flight, yet these are the opportunities which are the most numerous, and which must be relied on for the bulk of the shooting; in short, that is ruffed grouse shooting.

If the shooter be too indolent or apathetic to be ever ready to shoot, or if he is too slow to take advantage of the opportunities, his success will be but meager so far as material results are concerned, though he may be greatly encouraged by the belief that his last ill success was due to faults in the bird, and that if he can have another opportunity he will acquit himself nicely. The opportunity comes, and failure again evokes more excuses. Once in rare whiles the shooter will have a good opportunity, catching the bird in some corner so favorable that the advantage is with the shooter; but such instances are rare indeed, and by themselves would make but little sport. 
To be ready for the opportunities the sportsman must be quiet, and never relax his vigilance, and his gun must be so held that it can instantly be brought into position to shoot. The nerves of the shooter must be constantly at a high tension in readiness for the rise of the bird and the instantaneous shot. Every faculty must be at a high key. The very moment that the shooter relaxes his attention will be the moment that the bird will rise, and before the sportsman can get ready the opportunity is gone. It will be seen that the man who dawdles with his gun, who is slow in the handling of it, or who is noisy, cannot hope for any satisfactory success in shooting the bird of game birds, the ruffed grouse. On the other hand, he can be keyed up to too high a pitch, overready when the bird rises. A nervous flurry does nearly as much to disarrange the desired results as does the more indolent dawdling. There are those, however, who can never overcome the nervous start at the roar of the bird's wings, though they may be perfectly undisturbed in any other bird shooting.

And the skill of the shooter, be it ever so high in degree, must be supplemented by the work of a quiet, well trained, industrious, intelligent dog, for the shooter is much better off without any dog at all than with one that is riotous or one that ranges too far or that is heedless of his work. Loud orders to the dog have no place in ruffed grouse shooting. The sportsman himself cannot observe too great a silence. The human voice alarms and puts the birds to flight. 
The work required of the dog in this shooting is distinctly different from that required in any other kind of bird shooting, except, perhaps, woodcock shooting, which in a way it resembles, though a higher degree of $\mathrm{dog}$ intelligence and obedience are required, as the ruffed grouse is far more cunning and wary than the woodcock.

The "partridge dog" should not work far from the gun in cover, and he should be silent and diligent in his quest. Many experienced shooters highly commend the use of a small bell tied to the dog's collar, its low tinkling constantly indicating the dog's whereabouts in the thick cover; and generally, when the bell stops, it indicates that the $\operatorname{dog}$ is on point, thus in a way keeping the shooter posted by ear as to his dog's doings and whereabouts.

The rattle-headed, highly nervous dog, or the one which gallops swiftly and merrily about, is distinctly out of place in this kind of shooting. The rsthetic shooter, whose dog must carry a high head and a tail lashing his sides merrily as he gallops and bounds about in the ecstasy of his enjoyment, as the dogs many times do in the idealists' tales of great work afield, would better take his fiery dog into the open, where he can better disport himself unhampered, and where his pretty ways may be admired without any unpleasant interposition of the ruffed grouse. Such manner of the dog's seeking is incompatible with ruffed grouse shooting, for the shooting should be the dominant feature, not the joyousness of the dog. 
A dog of fair gait and persistent industry can easily beat out the necessary range, and the one which makes his quest patiently and soberly and quietly, working with judgment and honesty to the gun, will bring the shooter satisfactory success in the results, to say nothing of the incomparable comfort and pleasure in shoot. ing over him.

Nine out of every ten dogs which are running with high head and merry actions are running because they are in high spirits and for their own pleasure, with no thought of the birds or of work to the gun. When they come on birds this is often a matter of chance, and their point work is marked by deplorable errors. This kind of dog leads his partial master to believe that when he wears off the wildness and wire edge he will steady down to a useful grade of work; but often when such dog has worn off his exuberance he has worn off all there is in him of field performance, and he either loafs, or does his work in the same slovenly manner, though, loafing, he does less of it.

In shooting for sport, the shooter takes his birds on the wing. Of course, in shooting for market, the market shooter has no thought of sport or its practices. His one object is to kill the bird and bring it to bag. The manner of it is of the least importance. His theory and practice are founded on commercial principles; therefore, he shoots his birds as he can, whether they be on the limb of a tree, the ground, or flying.

Some hunters have dogs trained to seek for the 
birds, and, finding them, they flush and follow them. When flushed by the dog, the bird generally takes to the trees, and the dog, barking, so engages their attention that they fall an easy prey to the hunter, who often bags every bird in the covey under such circumstances. Often, when flushed by the dog, they fly to the tree-tops immediately overhead, where, in fancied security, they watch the dog. The shooter then drops them one by one, taking the lowest birds first. The falling of the lowest ones does not disturb those above, though if a top bird is dropped the others fly away forthwith.

As to the number a shooter can kill in a day, so much depends on the shooter's skill, the bird supply, and the local shooting conditions, that these things alone determine it.

In some sections of New England, two or three birds at the end of a day of diligent effort is considered a highly successful result, and it is not an infrequent occurrence in that section that a diligent day may have no birds at all at its ending.

In certain sections of New York, Wisconsin, Minnesota, Dakota, etc., and in the mountain sections where the ruffed grouse abound, such a bag would be considered an absurdity, if held forth as an index to good shooting, industry and superior results.

While in North Dakota I have heard of one bag of eighty birds, made to one gun in a day, something extraordinary. They were shot at the air holes along the banks of the Red River, after it had frozen over, 
the birds coming to those places for water. This was not recounted to me as a matter of sport, nor is it so set forth here, but will give an idea of the numbers of the ruffed grouse in the sections where it is in the greatest abundance.

But the sportsman who seeks the ruffed grouse for the true sport of it has a more exalted pleasure than comes from shooting any other game bird. First of all, he must be skilful with the gun, and when he shoots, be he ever so skilful, he can only apply such skill as he can muster in a moment, the opportunities of ruffed grouse shooting being but mere fragments of the opportunities accorded to shooting in the open.

When at length the bird is brought to bag it represents a toiling through brush and bramble, wooded lill and dale, scrambling over ledges and floundering through swamps, all colored by constant expectancy, unavoidably lost opportunities, and seeking to circumvent the birds by cumning woodcraft, supplemented by the powers of the dog-a degree of cunning, skill and persistent effort greater than that required in the shooting of any other bird.

It is shooting pitched in the highest key, and that is why I think the shooter can justly feel a greater glow of pleasure when he makes a successful shot at ruffed grouse, and why he loves this sport above all others, since it tests to the utmost his skill, his woodcraft, his patience, his endurance and his dog; and of the dogs, if he owns a good one, he owns one of a thousand. 
Many sportsmen will not agree with Mr. Waters' belief that a ruffed grouse in the open is as easily brought to bag as a prairie chicken. They even declare that the ruffed grouse flies three times as fast as his pinnated cousin, and is at least twice as difficult to hit.

In his recent volume on "Life and Sport on the North Shore of the St. Lawrence River," Mr. Nap. A. Comeau says :

"Ruffed grouse shooting in this section is not sport, and is not regarded as such by the residents, for the reason that neither the people nor the birds have been educated to it. I can count on less than the fingers of one hand all the men $I$ know on this shore who will deliberately flush a grouse to shoot it on the wing. As for the birds themselves, unless they happen to be in an open spot, they will not fly any distance. In the woods, which are pretty dense here, when flushed they simply rise off the ground, perching in the nearest tree and stretching their necks to see you walking under them. If it happens that a covey is started they will frequently be all killed without any of the others around taking flight. Many a time when in the woods trapping we would not waste a shot on them, but simply go to work and cut down a small sapling, tie a noose or string at one end, slip it over their head and pull them off the branch. At other times, for amusement, we would go out with a bow and a blunt-headed arrow and whack them off the trees at twenty feet range, which is about the usual one that they are shot at here. "What a contrast to the educated ones! Some years 
ago I received an invitation from C. Beatty, of Plattsburg, Lake Champlain, to go and have a few days of mixed shooting with him. It was late in September, but most of the leaves were still on the trees. The first day we had a grand duck shoot on Missisquoi Bay, and after that an outing for woodcock. The last day had been reserved for partridge and gray squirrels. We had breakfast at daylight and were off. We had not far to go to reach our ground-patches of hardwood trees with a good deal of underbrush. We soon heard some whirring off at our approach, but could not even get a glimpse of them. After a time I got a crossing shot at one, over fifty yards away, which I bagged, and that was the only bird we got. But we surely heard a dozen or more rising. I was simply astonished that such a bird could be so shy. When I came back here and told the natives about my experience, they thought I was pulling the long bow. I believe it will be many years before our birds get so highly educated."

\section{DUSKY GROUSE SHOOTING}

To my mind, the most splendid of the many American grouse is the dusky, or blue, grouse found in the Rocky Mountains, north to Alaska, and west, at various points, to the Pacific coast. To be sure, it is not as large as the sage grouse, yet it is a big bird, sometimes weighing up to four pounds, and nearly two feet long. Its tender and delicate flesh is always good eating, and its habits of life, in underbrush and timber 
along the mountain side, make it seem much more a bird for sport than the larger sage grouse, which is found on the dry, hot, open prairie.

In these days, when cities, towns, villages and farms are scattered all over the range of the dusky grouse, there must be a multitude of men who follow this bird with dog and gun, and shoot it much as people in the Eastern States and the Mississippi Valley shoot the ruffed grouse; yet, curiously enough, we hear very little of killing this bird in a sportsmanlike manner.

Shooting the dusky grouse before the broods are full grown, and when they are more or less scattered out to feed, is but tame sport. The birds lie like stones, and fly straight and easily, dropping at a touch of the shot. In September and October, when they are full grown, it is quite different, however. Then they are strong of wing and fairly well able to take care of themselves; all the birds are large, and while they still present a fairly easy mark, they fly with great swiftness, and from the situations in which they are often found the shooting calls for readiness and care.

In the old days, when no one in the West thought of carrying a shotgun, it was often necessary to kill birds for food, and then the young broods of dusky grouse often gave one a little practice as they stalked ahead of one up the valley or stood on the branches of the trees of the mountain side. At a distance of twenty or thirty yards, provided one thoroughly knew his rifle, it was considered fair shooting to knock the heads off four out of five of these young birds. In- 
evitably there was a miss now and then, when a walking bird would unexpectedly stop, or would move its head to one side just as the trigger was drawn; but as I say, we used to be able to cut the heads off four out of five.

In the same way, when a brood of dusky grouse flew into a tree, and stood there unfrightened by the report of the rifle, a number of them could be secured, pains being taken always to shoot the lowest bird-in deference to an aged tradition-in order that others might not be alarmed by a fluttering body falling close to them.

One of the best morning shootings that I ever had at dusky grouse was in northwestern Montana, on one of the high benches that overlook the St. Mary's Lakes. It was a rounded knoll-an old lateral moraine-a mile or two long, once overgrown by aspens, which had been killed by fire and had now fallen and rotted. A new growth of aspens, just starting, reached only about up to the knee. Among these little aspens grew huckleberries, and the ground was more or less carpeted with the vines of the bearberry-the smoking weed called "larbe," perhaps a corruption of the trapper French word l'herbe. On these berries several broods of grouse were feeding, and after camp had been made near the upper end of the knoll I took my shotgun and walked back over the ground where several birds had been started.

It was not long before, with a thunderous roar, a full-grown bird rose but a few yards before me, and, 


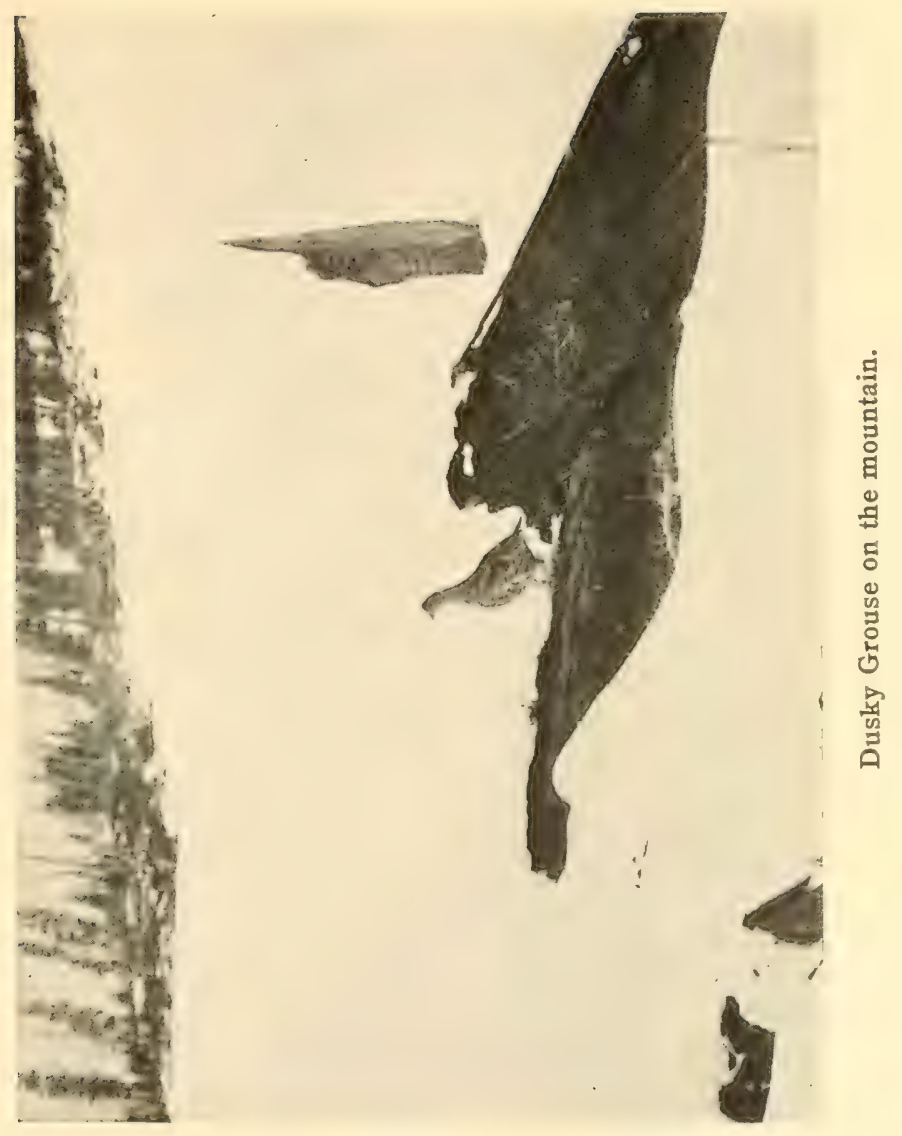



scaling off on the fresh breeze that was blowing down the lakes, was thirty or forty yards off before the heelplate touched my shoulder. Luckily, I held on the bird, and the center of the load hit it so that it fell quite dead. At the report two more rose near me, and this time I brought my gun to bear a little more quickly, and killed the second one. Two or three more rose at this report and flew down the lake, but they did not fly the whole length of the knoll, and I marked them down.

It was evident that if this lasted I was going to have good shooting, and so it proved. I went on, more slowly and carefully, and tried to pick my shots. As I had no dog, only the birds immediately in my way got up, except that sometimes, when a shot was fired, several rose ahead or to the right and left, and most of these pitched off down the hill, and, scaling off on the wind, reached cover in the thick aspens of the lower ground, where I knew it would be useless to follow them.

Before I had reached the lower end of the knoll I had more birds than I could carry, and I was not sorry to see my companion coming after me on horseback to relieve mc of the load. The shooting that he had heard had notified him of the sport that I was having, and he rightly concluded that I would need help. I was interested to notice, as he came toward me, that he put up a number of grouse, though his route was not far from the one I had followed.

When we had tied our birds on his horse it was 
found that I had already ten, which I estimated to average not far from three pounds apiece in weight. Just at the end of the knoll, and as we were about to turn back to go to camp, a grouse jumped up before me, at the foot of a clump of aspens, and dived into them, precisely as a ruffed grouse would pitch into a piece of underbrush. Just as I should have snapped at a ruffed grouse, so I snapped at this bird, and a moment later a loud splash in the water, and a muffled drumming, told that the shot had reached him just as he was about to cross the river. My companion went down, and riding out into the water, picked up the eleventh bird.

A little later, on the way home, another grouse sprang from some low aspens at some distance in front of me and pitched into a growth of pines, and this one I snapped at, again, but not with the success of the former shot, for the bird passed through the pines and flew a long way to a little island, where he seemed to go down.

If I had had a dog and a good shooting pony I could undoubtedly have killed forty or fifty birds in this one place; but forty or fifty would have been inexcusable slaughter, since there were but two of us in the camp, and we could not have used anything like that number of birds. As it was, those that I got that day lasted us for quite a long time, and most delicious food they were. The white, juicy flesh, sweet, and well flavored from the diet of berries on which the bird had been fed, was most delicate. Properly cooked, no 
bird is worthy of higher commendation than the dusky grouse. This is especially true when the birds on the lower plateaus are feeding on the tiny red huckleberry that grows in such profusion in the pine woods.

While the females are down in the lower ground, attending to nest building, hatching, and the rearing of their young, the old males and the barren females resort to the higher land, often being found on the mountain sides far above timber line. From such places they are often startled by the goat or sheep hunter, and pitching down from these great heights take long flights, at last bringing up down among the timber, and flying so far that no one knows just exactly where they go.

Nowhere, so far as my limited experience goes, is the dusky grouse pursued in so systematic and sportsmanlike a manner as on Vancouver Island, near the beautiful city of Victoria. My shooting of them there dates back many years, and it may be that in recent years the sportsmen of other parts of the Pacific coast have taken to shooting this splendid bird over dogs, as in old times they did near Victoria.

What good shooting there was at Victoria twentyfive years ago, and how varied the bags used to be! There were the pheasants rising like an explosion of fireworks, sometimes from under your very feet, and seeming-after you had ineffectively fired both barrels in the air in your fright-to wave at you in derision long brown tails that you almost felt you could grasp by reaching out the hand. There were blue 
grouse, big, and straight flying, getting up with a roar, and almost at once plunging into the dense thicket. There were ruffed grouse, simple birds, that you sometimes saw walking about on the ground not far from your feet, but ready enough, after they had been pointed by the dog and kicked out from their hiding place, to practice all the arts that their cousins use three thousand miles away. Then, finally, there were the California quail, big flocks of them, more often heard running through the underbrush than seen, yet sometimes rising in thick flocks and darting off like little blue bullets through the timber.

It was here that, in company with two or three Victoria sportsmen, I first saw dogs used on the blue grouse; not always with success, for two wild young puppies, blundering excitedly through the underbrush and the heavy green forest, flushed the birds, some of which took refuge in the branches of the tall cedars or Douglas firs, quite out of reach of the shotgun.

There was one old white setter, however, which regarded the younger dogs not at all, but trotted methodically through the forest in businesslike fashion. To him and to his owner I attached myself, and during the day had the opportunity to see him point half a dozen birds in most workmanlike style. The grouse lay well, and did not run ahead of the dog, as an educated ruffed grouse would have done. At the same time, when flushed, the birds displayed wonderful quickness in putting some object between themselves and the gun; though in this case, as there were two 
guns, the stratagem was not always successful. No great amount of wisdom was required to circumvent these birds. They had not been subjected to the constant pursuit suffered by the ever persecuted ruffed grouse of our eastern covers, and did not resort to his puzzling devices. They afforded great sport, but the shooting was very destructive to the birds. On the other hand, the thick cover which prevailed over much of the forest did not permit following up the birds, and if not secured on the first rise they were not seen again.

No doubt at the present time the dusky grouse are frequently shot over dogs in the Rocky Mountains. Any dog which had been broken on ruffed grouse would be serviceable also in finding its larger relative. Yet as the dusky grouse has been, until recently, altogether without education in this respect, the extreme caution needed in a dog used for ruffed grouse shooting would scarcely be required for the dusky grouse.

It would be interesting to know whether, in modern days, the ruffed grouse, or the dusky grouse of the nurth Pacific coast, had been sufficiently pursued to acquire a wisdom which men of the eastern part of the continent usually expect the ruffed grouse to possess. 


\section{PTARMIGAN SHOOTING.}

Ptarmigan are never shot for sport, but only for food. Occasionally a few birds may be secured on the wing, but usually the ptarmigan is not found in situations where the gunner is able to pursue it in a sportsmanlike manner. Commonly he is traveling, is without a shotgun, and is thinking more of filling his pot for the night's meal than of giving the bird a chance to escape. Practically the only exception to this rule is Newfoundland, where, under the name of partridge, the ptarmigan is commonly shot over dogs, and gives excellent sport.

Mr. Comeau, in his "Life and Sport on the North Shore," speaks most interestingly of the migrations of the willow ptarmigan, and tells of the extraordinary numbers of them that are killed. He says:

"During the last two migrations, taking the best years, I895 and I904, I took some trouble to try and find out, approximately, how many birds were killed between certain points. During the first year mentioned, between Mingan and Godbout, I75 miles of coast, 30,000 were killed; in the second (1904), I4,000; and I am sure that during I 885 nearly 60,000 must have been shot or snared. When a flight begins, every man, woman and boy able to handle a gun is out. To avoid accidents, which are very rare, indeed, 


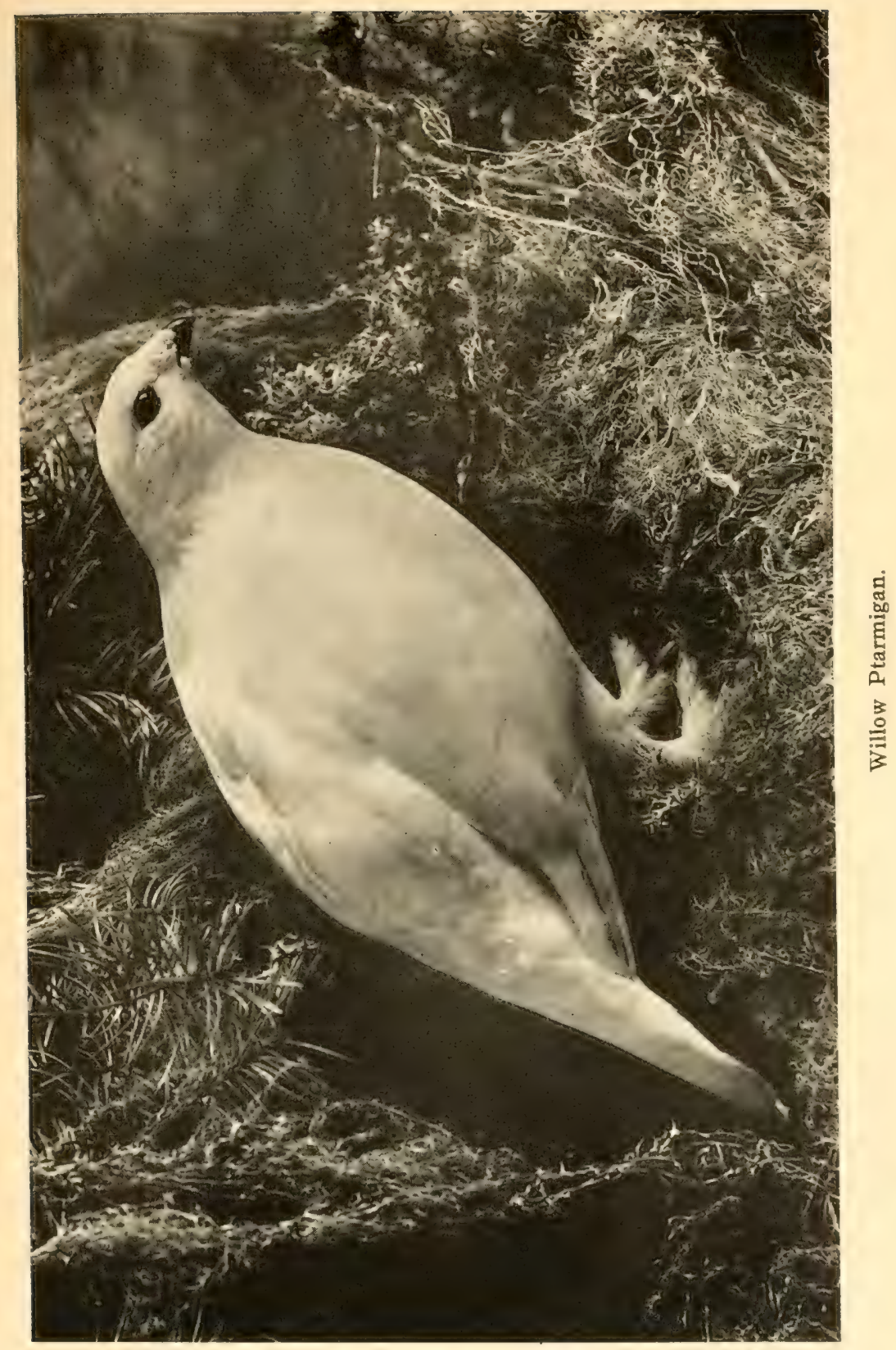



each gun occupies a certain point or station, and shoots at all the birds that pass or alight in his vicinity. The ladies keep watch for those that may alight near the houses. The bags vary, of course, according to the skill of the shooter and his method of shooting. If he is there for business he will take all the pot shots. He can frequently get five or six in one shot. I have seen fourteen killed in a single shot. A few will only shoot on the wing, but there are many days when the wing shooter comes out ahead. The biggest bag I ever made (it was in I885) shooting at flying birds was eighty-two brace in one morning. At Caribou Island, that winter, nets were tried, but they were not very successful, more being got by shooting. Indians frequently snare them by setting their snares around willow clumps where the birds feed. It is a very simple arrangement. A twig is stuck in the snow, a twine snare is tied to it, a very light support placed under it to hold it in position, and it is ready. In walking around the bird runs into it, then tries to rise on feeling the snare, only to tighten the noose. There is a little fluttering, and it is all over."

Such is the abundance of the willow ptarmigan, and sometimes of the rock ptarmigan as well, though this last is not so numerous, and such is the way in which they are killed for food.

Rarely it happens that the earnest ornithologist or the big-game hunter in search of a new sensation toils laboriously up to the home of the white-tailed ptarmigan, carrying his shotgun with him. When he reaches 
the haunt of these little birds he is very likely to be disappointed. Either, on the one hand, they trot along before him, refusing to rise on the wing, or else they are so shy that long before he is within gunshot they take wing, and fly off along the mountain side, only to repeat this operation when again approached.

Like all the grouse, the white-tailed ptarmigan, when almost fully grown, are very gentle and unsuspicious, and may be approached within a few feet; but as the nights grow colder and the autumn storms begin, they grow more and more shy. Finally, in September or October, they are wild birds, often rising at good gunshot distance, flying thirty or forty yards, and, alighting on the hillside or on some great rock, walk about with head and tail held high in air, in an attitude of great suspicion. If by chance they are closely approached when on a steep hillside they often throw themselves into the air and scale downward with great swiftness, sometimes continuing their flight across a narrow valley, so that it is quite impossible to follow them.

In the days of their youth, before they have grown shy, many are killed in the mining districts of the high mountains with stones or clubs, by miners going to and from their work.

In Newfoundland, the willow ptarmigan, and occasionally the Newfoundland form of the rock ptarmigan, used to afford superb shooting over dogs; but as with so many other game birds in many places, they have been so overshot there that it is now reported 
that they are comparatively few in number and that good shooting can no longer be had. What it was in old times may be inferred from an article long ago contributed to Forest and Stream by M. Harvey, who, formerly wrote so much about Newfoundland, and, as one of the historians of the island, did much to make it better known to the world at large. The substance of the article is as follows:

The ptarmigan or partridge ("patridge" in our local vernacular) of Newfoundland is quite equal to the Scotch grouse, and, indeed, resembles it so closely that it is difficult to make out any specific difference between the red grouse, gorcock or moorcock of Scotland and the ptarmigan of Terra Nova. They are a most delicious article of food, whether roasted, stewed; or in white soups. All visitors to our shores admit that the flavor of a plump partridge, well cooked, is unsurpassed in richness and delicacy. They are of respectable proportions, a brace of them, in season, weighing from three pounds to three pounds and a half. When the shooting season opens, on the first of September, they are in prime condition after feeding on the wild berries, the partridge berry and cranberry being their favorite food. In certain localities they are very abundant, and to the sportsman there can be nothing finer than a day's partridge shooting over our breezy barrens during the fine autumn weather. The air is then cool and exhilarating, and the skies bright. The weird and charming scenery is varied by countless lakes or 
ponds and by low, rounded hills, covered to the summit with the tapering firs. The lakelets are bright with the white and yellow water-lilies; between the summits of the bold headlands along the coast glimpses are had of the restless Atlantic. All these natural beauties, combined with the excitement of the sport, furnish to the lover of nature a day of rapturous enjoyment.

It is a thrilling moment to the sportsman when, gun in hand and dog at foot, he finds himself among the partridge coverts. His faithful dog scents the game, and every nerve in his frame quivers as, step by step, he thoughtfully and cautiously advances toward the unseen covey; then, suddenly pausing, the right fore paw balanced lightly, and every limb and muscle tense and rigid, the beautiful animal is at once transformed into a marble statue. Presently a whirr is heard, and with a loud $c a, c a, c a$, a magnificent old cock rises on the wing. Crack goes the gun, and down tumbles the great bird, the scarlet tips over his eyes glistening like rubies, as with a thud that gladdens the sportsman's heart he strikes the earth. Or perhaps a whole family - father, mother and children-rises at once, and the double barrels bang at them right and left, bringing down two or three brace.

At times a late covey is started, the chickens of which are only two or three weeks old, just able to run smartly along the ground. It is a touching sight then to see the cock fearlessly exposing his life to save the lives of his offspring. He tumbles along the ground a few yards in advance of the dogs, rolling there in order 
to decoy the sportsman from the brood, which the hen is anxiously calling into the thicket. No more touching instance of paternal affection could be witnessed; no more touching proof among the lower creation of self-sacrifice prompted by love. The poor feeble bird would almost attack dogs and men in his efforts to save his children. No true sportsman would harm a bird under such circumstances. Only a brute would fire upon it. The dogs are called off, and father and mother ptarmigan are soon rejoicing over their rescued family.

At times, the ptarmigan here are so tame that they can be killed with a stick, and at others so wild that they will not allow you to approach within gunshot; and this is generally the case in winter, when the snow is hard and crusty, and the noise made in approaching them alarms them. They are shot at all times by our population in the distant districts, but a close time is now fixed by law, which will have a good effect when the law can be enforced.

There is another species found in Newfoundland, but it is comparatively rare-the rock ptarmigan, $L$. rupestris (Gmelin). It is a truly alpine species, and is seldom found below the line of stunted black spruce, except in the depths of winter, when they descend to the lowlands and feed on the buds of dwarf trees, sometimes in company with the willow grouse. Our settlers call this the mountain partridge. 


\section{SHOOTING THE PRAIRIE GROUSE.}

The shooting of the prairie grouse differs widely from the same sport on the woodland species. In the one case the birds are likely to dart into cover, disappearing almost at once, and snap shooting is the rule. In the other the bird rises in the open, seems to fly with deliberation, and the gunner has every opportunity to make all his calculations, take careful aim, and cut down the bird before he gets out of shot. Only in the case of the sharp-tailed grouse, after they have moved from the high uplands into brushy ravines or wooded hillsides, is there any similarity between the two styles of shooting. In September, after the sharptailed grouse are grown, they spend the middle of the day in wooded ravines or willowy bottoms, where cover is often thick, and a single gunner, who has no dog, and is trying to tramp the birds out of their places of concealment, may have to do more or less snap shooting; but if he have a good dog that can be trusted to work through the bottom, the gunner can usually so place himself as to have clear and open shots.

As the laws of most States now read, the prairie chickens-of whatever kind-are reasonably well protected; but formerly, when shooting began, during the month of August, at which time the birds lie very close, it was not uncommon for two gunners to ex398 
terminate a brood, and in many places, a few weeks after the shooting season had begun, there were practically no grouse left on the prairie. When, however, the shooting season begins in October, or even November, as is now sometimes the case, the birds are shy, scarcely lie to a dog, and are strong of wing. To kill them in great numbers is not an easy matter under such conditions.

\section{PINNATED GROUSE SHOOTING}

To-day there are few places, except in Texas, where much pinnated grouse shooting may be had, but thirty or forty years ago things were very different. Then men would start out on foot, and after two or three hours of shooting would return to their homes bending under a heavy backload of birds. Even later than that, great shooting was to be had in Illinois, Iowa, Minnesota and Nebraska. One scarcely dare say how large the bags used to be, but they were unquestionably large. Men hunted from wagons, carrying relays of dogs, with abundant water to keep them fresh at all times. Driving from farm to farm, and from village to village, they covered an immense area of territory and killed a great number of birds. In fact, at one time, during the first days of amateur photography, it was common to see photographs of such wagons nung around with game, and with the well-armed gunners and their dogs standing near. Happily, the taste for such pictures is slowly changing, though the big- 
game hunter still delights to photograph his camp with half a dozen deer hanging up in it, or to have his owin picture taken with his foot upon the body of the slain bear or moose.

Twenty years ago, when there were still prairie chickens in Minnesota, and plenty of them, it was well for the shooter to be early abroad. Breakfast must be eaten, the dogs looked after, a drive of perhaps five or six miles made to reach the ground, and it was necessary to be called long before daylight to reach the shooting ground as soon as the birds began to move.

It is hard to leave a comfortable bed in which it seems only a few moments since one settled himself to sleep, but a strong heart and prompt action brings the gunner out on the floor, and a few minutes of activity in putting on his clothes causes him to forget the comforts of bed. Then, how good breakfast tastes, and how eagerly he looks forward to the sport before him. The drive in the dark may be cold and uncomfortable, but the growing light promises warmth, which exercise certainly will bring.

In those days chicken shooting was lawful on the I5th of August, and the nights, though often damp and chilly, were not cold. There was an opportunity when there bred in Minnesota many ducks which have long since been expelled by the farmer, to get an occasional shot at teal, shoveller, mallards, and other homebreeding birds; but, after all, the chickens were the important thing. When the ground was reached the horses were put in the stable, or perhaps were driven 
through gate or bars into the extensive green stubble, where the dogs were turned loose and eagerly commenced to range. On they go for some hundreds of yards, crossing each other at high speed, with heads high in air and merry tail action; but presently there is a pause, one of them checks himself, and makes game, quartering here and there with nose close to the ground, and then making a cast, circling to try to pick up the trail of the running birds. The other dog joins him, and with a little rivalry they press forward, first one and then the other in the lead, until at last, drawing more and more slowly, one stops, and the other backs him.

The shooters hurry forward on foot, and presently are close behind the dogs, which are standing staunchly. One man pushes forward and walks up even with the leading dog, while his companion steps off a little to one side; and then, suddenly, just before the pointing dog, there is a tremendous hubbub, and three birds get up and hurry away on swiftly beating wings. Alas! they stayed too long. Two of them fall to the right and left of the man standing by the dogs, while his companion, a little to one side, accounts for the third. The rapidly succeeding shots start the rest of the bevy, which in a moment are on the wing, another falling to the last barrel of the man to one side. The dogs have sunk to their haunches, and are gazing eagerly over the stubble. In a moment of such excitement it is too much to expect them to drop flat.

Presently the guns are recharged and the dogs called 
up and sent forward for the dead birds. They advance very gingerly, and, picking them up, bring them neatly to hand. One of the dogs brings his always by the wing or neck, while the other grasps his bird about the body, and seems to rejoice in the huge mouthful that he has; yet he never bites nor apparently even pinches the bird.

Long before this both men had been watching the disappearing bevy, which flew far, and at last seemed to go down in a slough of high grass which interrupted the stubble. Here the young birds, lying like stones, were pointed hy the dogs and walked up by the gunners, one after another, until almost the whole covey was down; and so, very likely, it went on all through the day, until the heat of the midiay sun became too strong for walking or shooting or dogs, and a couple of hours' rest was taken.

Late in the afternoon this was repeated, and sometimes a great bag was made; but, after all, while this was killing, and was exciting enough, it was not what in these days would be called sport. The young birds lie very close, they present a large mark, and are too easy to hit.

The great destruction finally led to the almost total extermination of the pinnated grouse of the West in regions where it had always been most abundant, and to-day the sportsmen of that region are bearing the burden of the sins of their fathers.

The following charming account of shooting prairie 
chickens in Illinois, in the old days, is abbreviated from a sketch from the pen of Wilmot Townsend, whose charming contributions to Forest and Stream have been well known for so many years:

The prairie has been likened to the ocean, and the simile is not altogether wide of the mark; and as one looks out over the boundless expanse of rolling grass land that spreads on every side until land and sky meet on the horizon line, it does not require a great effort of the imagination to see the resemblance. Though the waving grass gives life to the view, it lacks the mighty heave of the ocean; that ceaseless pulsing of the waters is wanting; the swelling waves of prairie land seem to have stiffened and died, deserted by the impulse which gave them birth.

The mere turning of the sod reveals a rich dark loam, that, without fertilizing, will yield immense crops of corn and produce a wonderful return in golden grain. In late autumn the chickens resort to the fields of standing corn to glean, and rich pickings they find.

On a still, clear morning the scolding of the cocks begins at sunrise, and the air resounds with their kek$k c k$ ! kek-kek! until long after the hoar frost has disappeared. Then you will see flock after flock leave the prairie and enter the corn, there to remain throughout the day, unless disturbed. A short hour before sunset they run out to the edge and spring into sturdy flight for the night bivouac on the open plain. At this season these camps of the prairie chicken often contain thousands of individuals, representing hundreds 
of coveys, that arrive from all quarters, coming sometimes from a distance of miles to this favored spot. One may frequently see some belated party string across his path as he tramps along just after sunset. Silent as owls, they flit past on outspread wings, and vanish in the gloom.

The shooting among the standing corn is, to me, the most exciting of any of the methods pursued in hunting this fine bird. ...

It is early in the forenoon, and I will see if I cannot find some of the birds I saw enter that eighty-acre piece a while ago.

We are presently in the thick of it, and save for the rustling leaves on the tall stalks which rise above our heads it is very still. The chickens are running, as I see by the trailing of my dog, and it is necessary to step out briskly in order to keep him in view. There! He has struck a hot scent! Hear how his tail is beating a tattoo on the stalks as he worms his way along, crouching close to the ground in his eagerness to locate the birds. At last, with head almost at right angles with his body, he stands rigid.

There they go. A dozen chickens whizz up through the corn about us. I catch a glimpse of one just as he clears himself, and pull on him almost without sighting. Crash! thud! Down he comes, and quickly I have him in hand, a fine young bird, as I find by holding him up so that his whole weight falls on the under mandible, which breaks under the strain. The difference in plumage of these full-grown birds is very slight, 


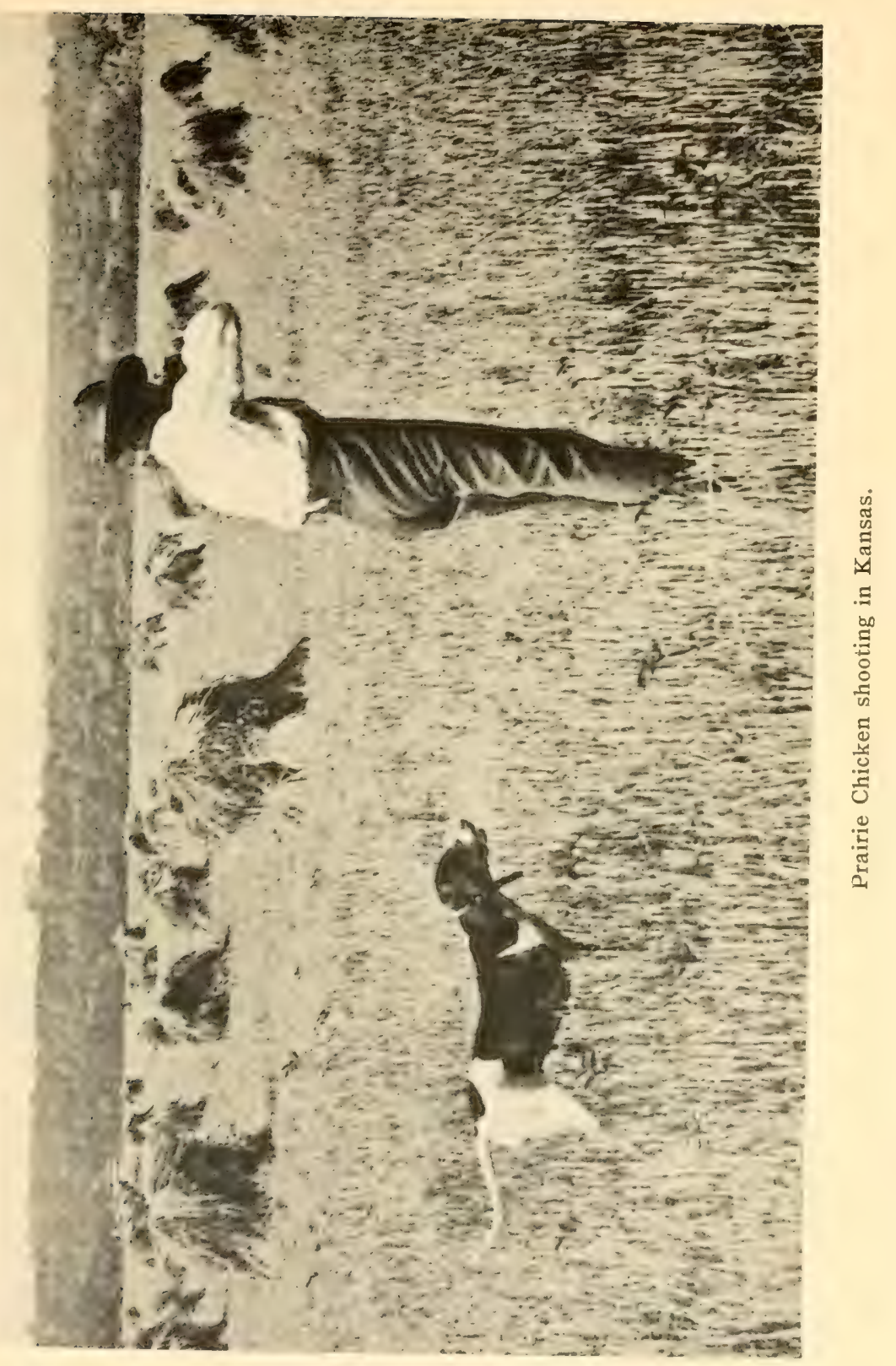



and it is by this simple test that we may distinguish young from old. In an old bird the lower mandible always sustains the weight of the body without breaking.

The old dog is pointing again. A single bird rises this time, and sails off uninjured, though I give him the contents of both barrels. How easy it is to miss them in this cover, in spite of their size. We move on.

There has been a covey about here, as numerous tracks tend to show. It will take careful work to put them up now, as they have doubtless taken the alarm ere this, and are keeping well ahead of us. There they go again, off to the left. If we flush another bunch in this cover they will probably get up all together, as is their habit after being so disturbed. Try to pick your birds, for though they rise with a thunderous roar of wings, and look very large, you will find, as in quail shooting, that pot shots can seldom be made.

Here is the edge of the field. I think we will work around to where we entered, and after trying that little patch between here and the house I will wait until toward sundown, when they come out, and perhaps I may get a little flight shooting.

Chickens feed quietly among the corn, rarely betraying their presence, save to the keen nose of your dog. Once flushed, they lie very close for some time after alighting, and will not scatter until thoroughly satisfied that danger is past. This, however, is only in cover where they have been used to feeding undisturbed. Later in the season, when constant gunning 
has made them wary, they will make for the open at first flight, and rarely return before next morning. Look here! See where they have been dusting in this dry loam, just like so many old hens.

At four o'clock I walk out on the prairie to an old haystack, that seemed to be located near the center of their flight as they left the corn last evening, and lie down to await developments. High overhead a flock of wild geese is moving south; travelers, I guess, from the height at which they fly, and the silence and regularity of their action. Blackbirds in dense flocks are sweeping past, with incessant noise of harsh, rasping cries. Close by, a miniature whirlwind is sucking up the stray heads of buffalo grass and careering with them a short distance, where it leaves them awaiting the next puff that shall waltz them off again.

Keeping a sharp lookout in the direction of the cornfields, I presently see a covey of chickens rise. They come down well to one side, far out of range, but affording me a fine opportunity to observe their manner of flight. Rising with a burst of strong wing strokes, they attain an elevation of from 20 to 30 yards, and scale off on extended pinions for long stretches; then with a renewal of wing-heats they acquire fresh impetus. In this manner they alternate, now scaling, now flying along, until lost to sight over the prairie.

Here comes another covey. Now they are close upon me. Bang! one-bang! again, as two cross each other in flight, and down they come. There are numbers of chickens sailing by, but none venture in my 
direction. It is nearly dark when I reach the house, as night shuts in very (quickly. IIow cosy the firelight makes the room after the silence of the prairie.

The luxury of field shooting is pointed out in the following account of shooting in the Indian Territory. It presents a striking contrast to the sorrows of the eastern gunner of old times, who spent his shooting days in wallowing through swamps, squeezing anong alders and trying to break down cat-briars and grapevines:

I'rairie chicken shooting is, par crecllence, the sport of the lazy man. It is the easiest of all land shooting. First, because the field is always open, and if one is too lazy to walk he can shoot from a horse or wagon; secondly, because early in the season, before the birds are matured or have been too often disturbed, they lie in the tall grass as close and as long as one wishes; and thirdly, becatise they make a good lig mark, flying true, and not too rapidly, and there is so much of them that one need have no fear of blowing them all to pieces, leaving nothing but feathers in the air. If they happen to get up too near for a shot you can measure your distance, knowing there is no bush or tree for them to dodge behind. Thus, in all respects, they make fine game for one not disposed to be in a hurry; and for these same reasons the gentle things are easy plunder for the unscrupulous market hunter. Later in the season, during the last of September, the birds are fully matured, lave lecome stronger flyers, 
and have been made a little more shy from an occasional shot among them, even in this far-off locality, and will not always allow a dog to approach so near them; and if a bird gets up twenty-five or thirty yards away one has to wink his eye pretty quick in order to stop him, for being strong, they will carry off quite a weight of shot unless winged, or hit in a vital part.

We shot mostly on the Omaha Indian reservation, which, here, is quite rolling, but excellent land, covered with a heavy growth of prairie grass; and there being no fences, we could drive at will in almost any direction. The Indians had here a few fields of corn and other grains, but there were thousands of acres over which we could ride and shoot at pleasure. Our wagon was a comfortable two-seated spring vehicle, with a park top, which would carry four to six persons and our dogs, and we had a couple of ponies, somewhat larger than jack rabbits, for a team, which would walk or run all day, but manifested a most decided disinclination to trot. We had two dogs with us, an Irish and an English setter, and our landlord had two Russian setters which were at our service.

Our mode of proceeding was about this: We would get an early breakfast, load up our dogs, guns, ammunition, lunch, a big jug of water for ourselves and the dogs, and point the ponies for the Indian reservation, when a ride of a little more than a mile would bring us to good shooting grounds. We always drove to the leeward of the field over which we designed to shoot. Then we would get out, leave Miss S. to 
manage the team, following slowly in our wake, and occasionally marking birds for us, which services she rendered in an admirable manner and with a new and delightful pleasure to herself. With the four dogs, the three of us keeping about two hundred yards apart and moving in line as nearly as practicable, each would generally find birds enough for his individual shooting without disturbing the others or placing them in danger; and when one's pockets became too heavy for comfort or convenience he would fall back to the wagon and deposit his load.

Occasionally we met at the wagon, to water the dogs, eat lunch, smoke a cigar, look over our birds, and when we were thoroughly rested, started out for another tramp. Thus we would put in time until about II o'clock, when it was time to bundle ourselves and dogs into the wagon and drive back to the hotel for dinner, after which, about 3 o'clock, we would find ourselves again seated in the wagon and on our way for the evening shoot, which usually lasted far into the "twilight soft and gray." To me there is a rare and indescribable delight in shooting on a still, quiet evening, watching the last rays of the setting sun, and the last faint glimmer of light as it quietly passes away under the gauzy curtain of night.

We always found supper awaiting us on our arrival home, when, after caring for the dogs and shedding our hunting traps, and taking a good bath, we gathered about the little round table, doing ample justice to broiled chicken and other good things. 
Should you ask me how many birds we bagged I could not tell you. I kept tally till we got past roo, and then quit. We did not forget our friends, nor neglect ourselves, for we sent away a box each day, and kept a string hanging under the little porch of the hotel from which our table was supplied at each meal. Thus we passed the week, changing our route occasionally, always getting birds enough to make it enjoyable sport, never turning it into downright slaughter, and leaving birds enough and to spare. And with it all we had a good time.

At the approach of cold weather the birds gather together in large flocks and pack, as the term is, remaining in these packs all through the winter. At this time they are shy, will not lie for a dog, get up at a considerable distance and fly a long way.

An interesting account of the birds at this time was written by Latrobe in his "Rambler in America." Latrobe accompanied Washington Irving and one or two other friends on an expedition to what was then the Far West-beyond the Missouri River, and like most Englishmen did not let pass the opportunity to get some shooting.

In 1832 he wrote of his efforts to shoot some prairie fowl. This was in Indian summer, at a time when the squirrels were at work among the dead leaves beneath the hickory and pecan trees near the Osage Agency, and when countless bands of water fowls and flights of pigeons, which had been constantly observed 


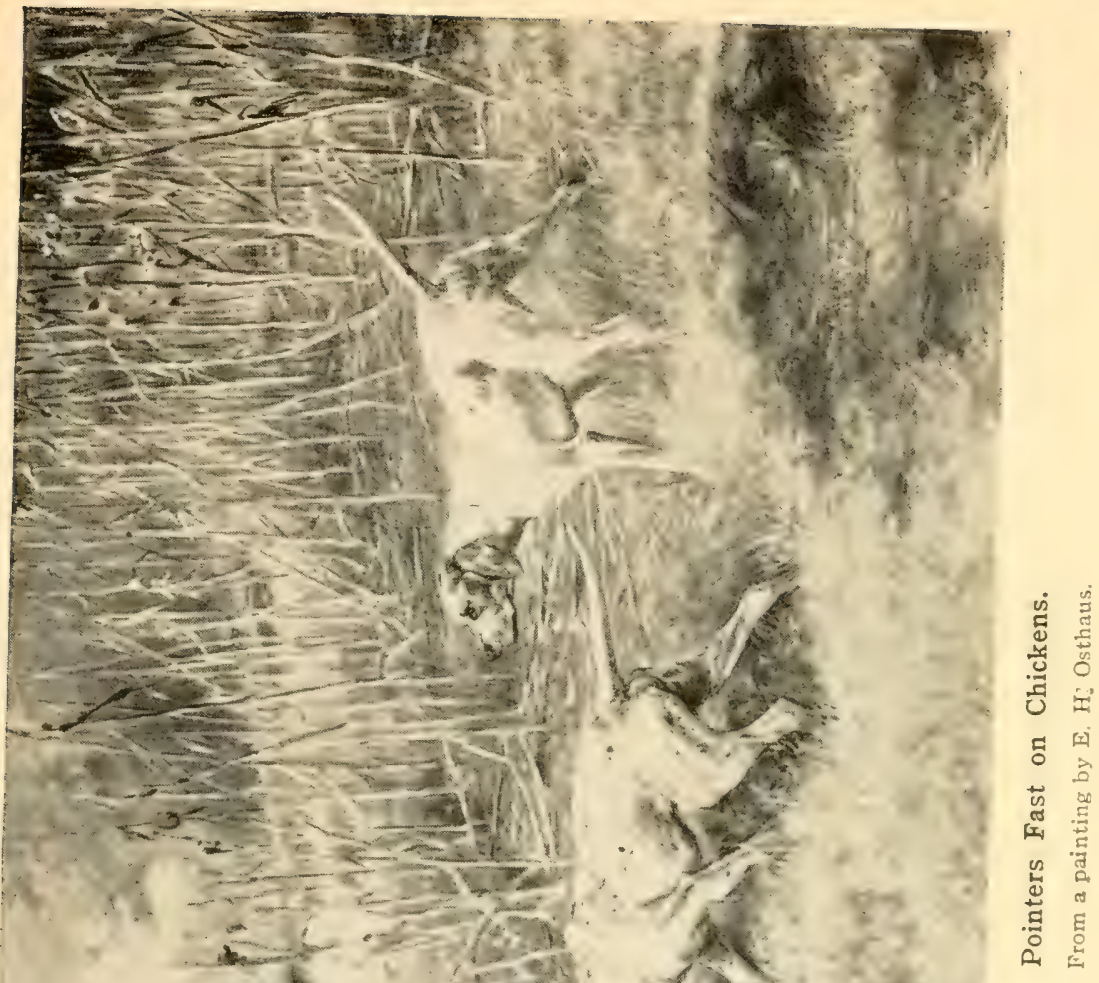



passing to the southward during a season of cold, had ceased to be a source of wonderment. He says:

"The prairie fowl had now completely thrown aside their summer habits. Instead of keeping apart in distinct families, scattered over a vast extent of country, like our grouse at an earlier season, they now appeared congregated in immense flocks in the immediate vicinity of the farms. I had plenty of opportunity of studying their habits, but to shoot a few brace, as they were extremely wild, required frequently hours of patient and wary exertion; whereas at an earlier season a sportsman, if aided by a dog, might bag any quantity from the pertinacity with which they will lie close until forced to fly.

"It appeared that at this time of the year all the birds within an area of three or four miles square congregated together by consent at sundown on a given spot in the rank dried grass of the unburnt prairie to sleep. Many a time have I seen them coming at sunset from every point of the compass with their remarkable level and even flight over the swells of the prairie toward the place of rendezvous, which a few days' observation enabled me to determine upon within a quarter of a mile, and twice I was on the prairie early enough to hear and see them rise, and the sight was such as might make an English sportsman's mouth water. The number must have amounted to many thousands, and the sound of their wings might be heard a very great distance. After rising for about half an hour they crowd the scattered trees on the edge 
of the prairie by hundreds at a time, after which they disperse. Their wariness at this time is extreme; and the slightest indication of the approach of man, even at a great distance, is noticed by the cock, who, perched on the topmost twig, elongates his neck and peeps first on one side and then on the other with the most provoking caution. How often have I been foiled, when, after the most cautious approach, either in serpent fashion like the Indian, dragging myself through the grass inch by inch, or in an upright position striving to counterfeit a tree stump, never stirring till the sentinel looked another way, and then, by imperceptible approaches and five more feet in five more minutes, would I approach the tree within range-the careful bird began to grow more and more doubtful and restless and finally sẹt up that clear, tremulous crow which said: 'There's a rogue with a gun almost within shot,' as plainly as though he had spoken English. The instant and complete dispersion of the whole covey to a great distance would be the immediate consequence."

\section{SHARP-TAILED GROUSE SHOOTING}

Except for the seasonal movements already mentioned, the sharp-tailed grouse is very local in habit. Half a dozen pairs of these grouse will build their nests and hatch their young along three or four miles of prairie stream, or the dry ravines which lead down to it. Mother and young will spend the summer on a range of prairie covering less than a sçuare mile, and there, 
in September or early October, one may find these broods of full-grown birds scattered over the hillsides at feeding time, and in the middle of the day gathered together in the shade of willows or box elders, or in a clump of rose bushes, from which, if disturbed, they rise with a startling roar and much cackling, to fly from seventy-five to two or three hundred yards, and drop in some convenient cover along the ravine or on a hillside. I have found them in southern Montana under just these conditions, where, if one had had a good dog and a shooting pony, it would not have been difficult to exterminate the whole brood.

It is soon after this, however, as the nights grow cold and frosty, that the birds get together in larger companies, several broods uniting, and in the early mornings take to the tops of the cottonwoods and willows, where they keep that excellent lookout that Mr. Latrobe has so well described in another species. At that time they are shy and quite impossible of approach in these exposed situations.

Though the sharp-tailed grouse rises from the ground with noise enough to disconcert the gunner of slight experience, it is not a difficult bird to kill. The mark is large and the bird's flight steady and straight. There is time enough to shoot carefully. At a straightaway, low-flying bird one may shoot directly, but crossing shots demand that the bird should be led a little. After all, this is almost wholly a matter of experience, and as almost all the shots are in the open, one may fire deliberately, and can, usually, if he misses, 
explain to himself why he did so and at the next shot correct his error.

Like all the prairie grouse with which I am acquainted, the meat of the full-grown sharp-tailed grouse is dark, though the half-grown birds are whitemeated. The flesh is tender and well flavored, as might be expected of birds that had passed the summer feeding on prairie insects and a variety of berries. In winter, when the character of the food largely changes, and willow and cottonwood buds constitute a large share of its dietary, its flesh is less toothsome, being much drier.

The sharp-tailed grouse, owing to the character of country which it inhabits, brushy ravines, willowy bottoms, and, at certain seasons of the year, hillsides overgrown with underbrush and some large trees, is much less easily killed than the pinnated grouse, and will probably remain with us much longer than that species. If it could be introduced to eastern covers, and protected until it had established itself, it would prove a grand bird for Atlantic coast gunners. So introduced, and so acclimated, it would, however, bear only the very lightest shooting, perhaps not more than three or four per gun in a season. More than that would soon result in their extermination, and the efforts put forth to introduce them would thus be wasted.

In the early days of western field trials held on prairie chickens in this country, the birds sought for were chiefly the pinnated grouse. These proved not sufficiently numerous, and were so readily killed that 
they did not give the dogs an opportunity to show off the best that was in them. A little later, therefore, a change was made, and grounds were sought where the sharp-tailed grouse was abundant. This was in northwestern Minnesota and in Manitoba, and here, for a number of years, were held what used to be called the chicken trials.

Before they have been much shot at the young sharptailed grouse lie well, and offer easy shooting; but when they attain their full growth, and the weather grows colder, they become much more shy, and while still spending most of their time on the upland prairies, seek refuge, when disturbed, in the ravines or the willows of the stream bottoms.

During the winter they get together in considerable packs, and live largely among the underbrush of the river bottoms; yet often they may be seen sitting on the roofs of buildings or willow trees, or fences immediately about the ranch, and sometimes at this season of the year, while roosting in such places, may be killed in large numbers with a rifle.

When it will lie, the sharp-tail furnishes fine sport with a dog, but often it runs for a considerable distance, and so rapidly that it may rise far ahead of the dog. As soon as the weather has become cool a quick eye and arm and a strong lead to the gun are required to bring the bird down.

In many respects the sharptail suggests the bobwhite quail, especially in the way in which it leaves the ground in flight and the speed with which it moves on 
the wing. In the late summer or early autumn it may be seen stalking about over the ground, walking quite differently from some of our other grouse, holding the head and tail erect and lifting its feet quite high, as if stepping over some obstacle before it. It is not easy to recognize in this seemingly absurd, affected bird the ball of feathers that a month later will rise from before your dog and speedily be out of range.

In some parts of the country I have heard gunners speak disparagingly of the sharp-tailed grouse, perhaps for no better reason than that they fly more swiftly and rise with more tumult than the pinnated grouse; but I regard them as one of the finest of our game birds.

\section{SAGE, GROUSE SHOOTING}

The sage grouse, which has its home on the high, dry plains, where grows the artemisia, harmonizes in color with the gray soil and gray stems of the sage brush to an extraordinary degree. When the sage grows high, and, as is often the case in river bottoms, is interrupted by frequent clumps of rye grass, one may even walk into a brood of the birds without seeing them, and perhaps have them rise all about him; or, on a sudden, his eye may catch a dozen heads, on tall, straight necks, staring at him from every side. The sage hen, it must be confessed, does not convey to the observer the idea of a game bird. When tame it is so gentle and unsuspicious, and when shy so 
clumsy and lumbering in its efforts to escape, that one hardly gives it credit for game qualities. It is a splendid bird, however, and its great size makes it a trophy of the shotgun eagerly to be sought after.

The range of the sage grouse is commonly believed to be coterminous with that of the plant whose name it bears. Though often seen in localities where no sage is actually visible, it never, we think, occurs far from the region where the plant is found. It is at home alike where the stunted shrubs of the wormwood grow only two or three inches high, or in valleys of the great central plateau where they are real trees, as high as one's head. In cover such as this the traveler may often ride up on a great flock of the birds, which are usually so unsuspicious that they will stand for some time before taking alarm.

When the birds do rise they get up heavily, with a lumbering flight; but after they have acquired momentum they go much faster than one would suppose, and it is easy to shoot behind crossing birds, whose great size often tends to make the shooter careless.

Inhabiting, as it does, a region of extreme aridity, and because the shooting season comes at the dryest period of the year, dogs would be at a great disadvantage in the pursuit of this bird, and I personally have never seen them used in this shooting. The bird is large, it inhabits the open, and is readily seen at some little distance. Though often unsuspicious, yet as the season advances, or in places where they have been shot, or much disturbed, they will often rise at 
a distance of I25 or I50 yards, and then make such long flights that it is useless to think of following them.

The adult sage grouse is tough and heavily feathered, and possesses great vitality. Unless properly hit it will carry away a heavy charge of shot. Young birds, on the other hand, drop to a mere touch. I have killed a great many on the wing with small charges of dust shot.

Many years ago a correspondent of Forest and Stream declared that, when there is reasonable cover, sage grouse will often lie to a dog better than the pinnated grouse. He adds what is now well knownthat the peculiarities of its home do not give the dog a fair chance to work or to do himself or the game justice, since the artemisia grows only upon barren prairies some 4,000 to I0,000 feet above sea level, where the soil is hard and dry, with little vegetation save stunted shrubs, cactus and an occasional clump of wild grass, where rain rarely occurs and there is little moisture in the air or upon the ground. When thick, the tough sprawling crooked evergreen, or rather evergray, shrub is often difficult for man, horse or dog to get through. The sage cock is a good skulker and runner, and not easily flushed if it can hide.

The same idea is suggested in Dr. Newberry's account of his first meetings with this great bird during one of the early explorations for a railroad route. It is in Volume VI of Pacific R. R. Reports:

"Coming into camp at evening, I had been attracted 
by a white chalk-like bluff, some two miles to the right of our trail, which I visited and examined. Near it was a warm spring, which came out of the hillside, and, spreading over the prairie, kept a few acres green and fresh, strongly contrasting with the universal brown of the landscape. In this little oasis I found some, to me, new flowers, many reptiles, and a considerable number of sharp-tailed grouse, of which I killed several, the whole presenting attractions sufficiently strong-as we were to remain in camp one day-to take me over there next morning. I had filled my plant-case with flowers, had obtained frogs, and snakes, and chalky infusorial earth enough to load down the boy who accompanied me, and had enjoyed a fine morning's sport, dropping as many grouse on the prairies as we could conveniently carry. Following up the little stream toward the spring on the hillside, a dry, treeless surface, with patches of sage brush (Artemisia tridentata), I was suddenly startled by a great flutter and rush, and a dark bird, that appeared to me as large as a turkey, rose from the ground near me, and uttering a hoarse hick Tick, flew off with an irregular but remarkably well-sustained course.

"I was just then stooping to drink from the little stream, and quite unprepared for game of any kind, least of all for such a bird, evidently a grouse, but so big and black, so far exceeding all reasonable dimensions, that I did not think of shooting him, but stood with open eyes, and, doubtless, open mouth, eagerly watching his flight to mark him down. But stop he did not-so long as I could see him, now flapping, 
now sailing, he kept on his course till he disappeared behind a hill a mile away.

"I was, of course, greatly chagrined by his escape, but knowing that, given one grouse, it is usually not difficult to find another, I commenced looking about for the mate of the one I had lost. My search was not a long one; almost immediately she rose from under a sage brush with a noise like a whirlwind, not to fly a mile before stopping to look around, as the cock had done, but, by a fortunate shot, falling helpless to the ground. No deerstalker ever felt more triumphant enthusiasm while standing over the prostrate body of a buck, or fisherman when the silvery sides of a salmon sparkled in his landing-net, than I felt as I picked up this great, and to me, unknown bird. I afterward ranged the hillsides for hours, with more or less success, waging a war on these birds, which I found to be quite abundant, but very strong-winged, and difficult to kill. I repeatedly flushed them not ten yards from me, and, as they rose, poured my whole charge, right and left, into them, knocking out feathers, perhaps, but not killing the bird, which, in defiance of all my hopes and expectations, would carry off my shot to such a distance that I would not follow him, even did I know he would never rise again. Here, as elsewhere, I found these birds confined to the vicinity of the sage bushes, from under which they usually spring.

"A few days later, on the shores of Wright and Rhett lakes, we found them very abundant, and killed all we cared to. A very fine male which I killed there 
was passed by nearly the whole party, within thirty feet, in open ground. I noticed him as soon, perhaps, as he saw us, and waited to watch his movements. As the train approached he sank down on the ground, depressing his head, and lying as motionless as a stick or root, which he greatly resembled. After the party had passed I moved toward him, when he depressed his head till it rested on the ground, and evidently made himself as small as possible. He did not move till I had approached within fifteen feet of him, when he arose, and I shot him. He was in fine plumage, and weighed over five pounds." 


\section{TURKEY SHOOTING.}

There are many methods of shooting the wild turkey, yet, after all, it is probable that it is more often killed by accident than by any one of the more approved methods. In other words, men traveling through the woods or fields stumble on the turkeys, flush them, and so get a shot.

In the South, "calling" is the approved and most used means of killing these birds. The hunter conceals himself in a blind, imitates the call of the hen, and so draws to him the other members of the flock. This is practiced with especial success either in the autumn, when the young turkeys are still innocent, or in the spring, at gobbling time, when the gobblers are likely to respond readily to the supposed call of the female. In regions where turkeys are plentiful, it is common for hunters to go out in the afternoon, and, finding a brood, to flush and scatter it. If night is near, the turkeys are likely to try to get together before roosting time, and to begin calling almost at once. If, however, it is too late in the day for them to do this, the birds roost in the trees, and in the morning are still more anxious to get together. The hunter, therefore, starts out long before daylight, repairs to the locality where he started the turkeys the night before, and concealing himself there, either by means of a blind con- 


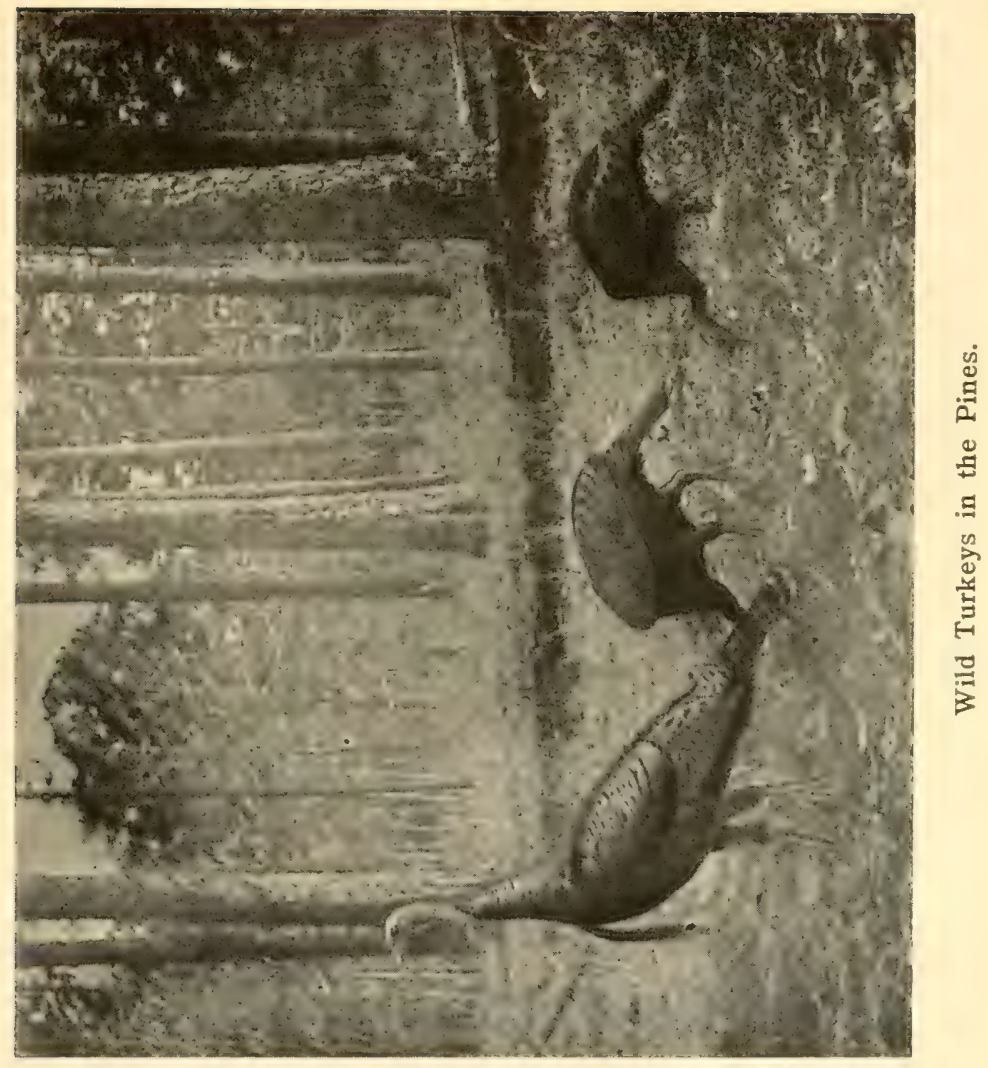



structed the night before, or in some thicket, listens carefully for the first calling of the turkey, to which he responds. In this way he may succeed in drawing several turkeys toward him.

The instrument used in calling turkeys is sometimes made of the bone of the bird's wing, sometimes of a iittle box floored with a piece of slate, the cry being caused by the stroke of another piece of slate on the slate in the box. At all events, the noise must be a good imitation of the turkey's cry, for the great bird is one of the most acute of fowls, and very little escapes either its eye or its ear. If the imitation of the cry is a poor one, answers will soon cease to come, and the birds will retreat.

Some years ago a correspondent, Tripod, wrote from Mississippi a brief but vivid account of the killing of a turkey by Miss Mary C. Breckenridge, whose experience with a shotgun was limited, but who, when the occasion arose, showed herself an apt pupil of her skilled instructor. She was new to the woods, and after traveling for some distance made up her mind that turkeys were a myth. Nevertheless, it was decided to call, and after a time, in the open woods, Miss Mary selected a good log for an ambuscade, while Tripod used the yelper, and at once received an answer from a nearby bird. The turkey kept approaching, ing, but before he had been seen a shot in the distance frightened him and he ceased answering. The turkey hunters sat quietly for a time, uttering now and then a little yelp, or cluck, when a twig snapped, and as 
Tripod carefully peeped over the log, there, not twentyfive paces from them, came a big gobbler, all fluffed up and strutting. He was coming nearer, so that prompt action was necessary. Tripod goes on :

" 'Now, Miss Mary, don't move a bit,' I caution.

"Her gun lay across the log, pointing in the direction from which the first answer had come, with its muzzle among some twigs, to free it from which the gun had to be withdrawn entirely from over the log and pushed forward again in a new place, as the turkey was approaching from a different quarter, very much askew to the log's position. This difficult movement in the face of the enemy was successfully accomplished.

" 'Now take the gun cautiously, aim carefully at his neck, low down, and shoot. Don't hurry!'

"She did it just that way, and over rolled that big bird. With great exultation we then bore down upon him, and saw him flutter, then quiver, and then lie still. On the lower part of his neck was much evidence of No. 5 shot. Miss Mary then looked much prouder than the turkey had looked a few moments before, and very justly so-and said turkeys were not a myth any more. I realized this myself as I bore this tangible specimen to where our horses had been left."

A successful turkey hunter, writing from Missouri recently, expressed his views of turkey hunting, and what he says, which I give in substance, will apply to the pursuit of the bird over much of its present range: 
To be a successful turkey hunter one must know his country and conditions, for unless the ground be covered with snow, and the pea crop has been a late one, the birds keep to the woods, where they are not easily seen in the tangle of hazel and blackberry.

Plenty of turkeys means a good crop of mast, for in autumn the chief food of the bird is the acorn, and the feeding grounds of the bird will be where the supply of acorns is greatest. If the crop fails in the swamps, most of the birds move into the rough hill country, for when the mast fails in the lowlands the hills are likely to have a very good crop, and a failure in the hills means an abundant harvest of acorns in the swamp. To find where the birds feed, however, is not to get your game, or even to see it. Often the scattered birds may be easily called up, but on the other hand, some flocks of young birds refuse to respond to the call.

To stalk the turkey requires more care and skill than to stalk the deer, and he who is successful in this description of hunting may congratulate himself. On the other hand, one may often blunder on turkeys without special effort, and may believe that he has mastered the art of turkey hunting; while the very next day he may not be able to get within long range of his game. Sometimes it is possible to walk close up to turkeys, so that one wonders if he has not fallen upon a flock of domestic birds.

As turkeys commonly roost over a water-course, or slough, as protection from danger, it is sometimes pos- 
sible, late in the evening or early in the morning, to pass under their roosts in a boat. If birds can be found in such a situation there is opportunity for good shooting with a rifle.

A very successful method of shooting them in Missouri is to ride through the timber on horseback, for the birds are not as shy of the approach of a rider as they are of a footman. On the other hand, turkeys alarmed are likely to make for swamps or down timber, where a horse cannot go.

If a flock of turkeys is scattered in the evening, at sundown, or frightened from its roost at night, the hunter who can be at the place before sunrise is likely to be able to get a number of shots by calling up the birds.

Shooting turkeys from the roost at night is a method that does not present many features of sport. Tracking birds in the snow is good sport, and calls for work and endurance. It is a very certain method of getting turkeys, but is obviously to be practiced only where snow falls.

An excellent description of the country in which turkeys are found in Arkansas, and of the opportunities which used to come to the turkey hunters there, is found in an account written by $\mathrm{J}$. E. London in the spring of Igoo. He says:

"While I was engaged in having some assessment work done on some mining lands in Newton County, Ark., in December, I899, I was informed by some boys 
who came to our camp that on the mountain north of us I could find a large drove of wild turkeys.

"The mountains in that section are very rugged, and heavily timbered, but the woods are rather open, the undergrowth being sparse and small. The timber is white, black and post oak, hickory, beech, walnut, cherry, and a half dozen other kinds, and such timber! Walnut six feet in diameter, and white oak the same. In fact, nowhere in the South does such a wealth of timber exist.

"One bright afternoon, taking my shotgun, I climbed the steep mountain for about one mile, to where a beautiful spring bursts from the rocks. I stopped, and was enjoying the solitude of the gloomy, grand old forest, when I espied a yellowhammer on a small tree, and shot him. This disturbed two gray squirrels, that ran to the top of a large wild cherry tree, but two loads of No. 6 put them in my game bag.

"I then started north along a path, but I had only gone a short distance when I walked out of the path to look down into a grove of post oaks, when I beheld a sight that put my.heart to beating like a trip-hammer. Twenty-six as fine turkeys as I ever saw, not two hundred yards distant, were feeding as though nothing could harm them, and paying no attention to the noise I had made killing the bird and squirrels. Armed only with a shotgun and some No. 2 shot cartridges, I began the task of getting in reach of those turkeys.

"Down on my knees and hands I went, and after forty minutes of hard work I was within seventy-five 
yards of them. Selecting two big gobblers that were close together, and in line, I gave them both barrels, and maybe there wasn't a racket on that hillside. One of them began to flop and whirl around like a chicken with its head cut off, and the other flew about two hundred yards at right angles with the remainder of the drove, that had gone over a high bluff into a ravine about one-quarter of a mile from where they rose. He came to the ground, staggered a few steps, rose, and when he had gone perhaps one hundred yards he let go and came tumbling down dead. I ran to the first one, and hanging him up in a small tree, followed the other, and did the same with him.

"Just then I heard some dogs on the opposite side of the mountain begin to bark, and a boy encouraging them. I knew this would turn the other turkeys back, so I hurried across a small draw and around to the north of where they came to the ground, and climbed on some large rocks, where I had a good view of the mountain side. In a minute or two I saw two hens coming for me on a dead run, and waited till they were within forty yards. I gave one of them the left-hand barrel, and as the other rose I knocked her a clean somersault.

"I now had four as fine turkeys as I ever saw, and not caring to hunt any more that day, I hung the two hens over my back and carried them to the gobblers.

In sections where turkeys still exist, and where snow falls in winter, a favorite method of hunting these 
birds is to take a track and walk the bird down. Usually, for several hours the turkey keeps well ahead of the hunter, the man steadily following the track and obliterating the turkey's trail as he goes. After a time the turkey is likely to grow tired, and at length to hide, when it can be flushed and shot on the wing. Sometimes, to be sure, if the ground was unfavorable for hiding, the turkey might fly, but usually it did not go far, and its track could be taken again. A short but well told story of tracking turkeys in the snow was printed in Forest and Stream, October 26, 1907, from a correspondent signing himself "Brinkstine." It took place in Missouri:

"We walked two or three hours, and not a sign of a turkey. Another hour, and yet no sign. We rounded a deserted field with no success, further than seeing plenty of rabbits and a few squirrels, but we did not want to set the hills quaking by shooting such game.

"We were tired. Walking in a foot of snow four or five hours steadily, and as silently as possible, is not conducive to a hilarious feeling, as one grows cold and hungry. We built a fire, ate our lunch, rested and warmed ourselves. We were almost discouraged, but started on with some hope of success. We walked two or three hundred yards, and found a turkey track, and a huge one. We had gone a quarter of a mile when the tracks of three other turkeys joined the one we were tracking. One turkey would not satisfy us both, so we were glad to know that there were four turkeys in the woods. Just as we were ready to start 
again we were chagrined to see George coming down the hill, trailing the three that had joined ours; but as age deserved consideration, we let him go in advance.

"Thus we came to a bottom covered with a growth of hazel brush, grape-vines and weeds, an ideal hidin? place for game. A cautious approach, and George looked over a brush pile and saw the turkeys sitting seventy-five or eighty yards away. It was impossible to approach closer, and George saluted them with both barrels, but got nothing. We marked the direction they took, and followed, George alone, and Riley and I after a huge one I had spotted. We struck a lively canter and ran quite a distance, as we knew he would run a long way before he tired and tried to hide. His tracks indicated that he was getting tired, so we slowed up and proceeded cautiously. Every fallen tree-top was closely scanned. The tracks led down hill toward a monster tree blown down during the summer, and which still had its leaves on, forming a splendid hiding place. We both recognized this immediately, and started to go one on each side of the tree-top. I stooped to go under the body, which lay three or four feet off the ground, when out burst the turkey. I dropped to get a view of him, and fired one shot as he pitched down hill. We ran across the ravine, and at the top of the next bluff found tracks where a turkey had alighted and departed in hot haste. A run of half a mile down the backbone of the hill, and we found the turkey had flown.

"Sadly we retraced our steps, while I caressed a 
weeping eye, through which a hazel twig had dragged, and we mused on what might have been.

"What on earth are you fellows doing, anyway?"

"We looked up, and there stood Uncle Will, giving us a rather tantalizing smile, we thought, as we remembered his caution as we left the wagon. We were not particularly glad to have him see us just then, as we came back panting and hatless. The best we could do was to tell him the straight of it, and as he was an experienced hunter maybe he could help us out. At the risk of being guyed, we even hinted that the turkey had limped as it ran away.

" 'Are you sure you hit it?' he asked.

" 'Think I did. I know that I tried awful hard.'

" 'Well, step here and see what this is, and tell me how it got there,' pointing to a big gobbler lying in a hole which it had made in the snow when it fell. How quickly I grabbed it up, admired its beanty and guessed at its weight.

" 'Here,' said Riley, 'you've got your turkey. Mine has just gone over the hill, and is on the other bluff. Come along, and we will get him, too.'

"We separated, seventy-five or one hundred yards apart, in order to cover more ground. We followed the tracks ten minutes, when we saw the turkey rise in open ground one hundred and fifty yards away. We marked the direction and hurried on, found the tracks, and followed briskly along the top of a broad, flat ridge. We had taken only a few steps through the tall grass when the turkey rose, twenty-five yards away, 
but directly between me and the sun. Quicker than thought my gun went up, a flame of fire leaped out, and was answered by the thud of the turkey as it fell.

" 'Confound you!'said Riley good-naturedly, walking over and picking up the turkey, a young hen. He took the gobbler and made me take the hen, weighing only about one-half of his load, and we set out for the wagon, four or five miles away. 'I am glad you got them, if I didn't get any,' said he. 'You got them both, and that is just as good.'

" 'No, it isn't,' I answered. 'You claim that you killed one, and I'll stand by you.'

" 'No, you won't. You killed them both, and you've got to have the credit of it.' And he was as good as his word."

The story of an oddly secured Thanksgiving turkey, killed in 1803 , in the Alleghany Mountains, was interestingly told in Forest and Stream, some years ago, by Mr. Edw. Banks, now of Wilmington, Del. A party of three, of whom Mr. Banks was one, had been shooting ruffed grouse near Bellwood, $\mathrm{Pa}$., but without any great success. There was a little snow on the ground and many tracks of turkeys in the snow. Presently the party went to a cold spring and sat down to eat lunch. While doing so one of them remarked that he wished he could get a Thanksgiving turkey. Mr. Banks says: "Lunch was about over when we heard a gun go off, with a regular old black-powder $d r$-ro-o-oom. It was not more than three or four hundred yards away from 
us, judging by the sound. Somebody said turkeys. The rest of us agreed. By common consent we jumped up and went to a pair of bars where an old woods road came out into the orchard, and stood looking in the direction of the sound.

"All at once out into the open, over the little valley, away up above the trees, sailed a turkey. At first it looked as if it were coming toward us, but almost instantly we saw that it had turned down the valley and was flying directly away from us, along the hillside. Our eyes followed it as it kept on its way for about a quarter of a mile, when suddenly up went its head and down it came, 'deader'n a mackerel.'

“' 'He got it, after all,' said some one. 'He did,' said Bill. 'Did you ever see anything like it?' said Jake.

"Then we returned to our lunch, and talked over the wonderful thing we had seen.

"Bill was quiet for a while. Presently he broke the silence with, 'Say, do your suppose that fellow who shot at that turkey saw it fall? Do you think he had any idea that he hit it?' That was quite a new idea to us, and we caught at it at once. It would be easy to follow the road in the woods and find out whether the man with the gun had turned off to the right or left anywhere. His tracks in the snow would tell us. We had marked where the turkey fell, right alongside of a monster pine which had been left when its brethren were taken by the lumbermen. Some three hundred yards along the road we saw where a man had come down into the road, and saw, also, that his tracks, as ' 
well as those of his dog, led along the road in the direction the turkey had flown.

"Following the tracks, we finally came to the big" pine, which was down hill, on the right of the road. The turkey had fallen to the right of the pine, and so was further from the road than the pine was. Jake and I turned off into the woods, which was open enough for us to have a good view of the ground. Bill went down the road a bit, to make sure that the man with the dog had not turned off further along, then he, too, turned to the right into the brush, and began to investigate.

"To Bill belongs the honor of finding that bird, a gobbler, too, wattled, bearded and bronzed as only an old gobbler can be. He was a beauty, with not a feather damaged and not a drop of blood on the snow. ... Was it our turkey, or did it belong to the man who had shot at it? By this time he was a mile or more on his way, and that turkey certainly did look good.

"At all events, we took the bird back with us, and if I remember rightly, it weighed just a fraction under twenty-two pounds at Bellwood. There was not a fresh shot mark on the body when I removed the skin for the taxidermist, who found, however, when he was taking the head from the neck, that a single small pellet, hitting the bird in the head, had cut a large vein in the throat, and the bird had bled internally."

In Kansas, the Indian Territory and Texas, where the turkeys necessarily roost in the trees growing alons the river bottoms, the practice of shooting them $0: 3$ 
the roost was long a common one. If a roost was found, the hunters sometimes approached it during the afternoon, and concealing themselves, awaited the return of the turkeys, and perhaps the rising of the moon, so that the great birds might be seen against the sky. At all times, and especially in sections where turkeys had not been much hunted, it was easy to ride one's horse beneath a roosting-tree, and there dismounting, to fire into the birds above. Stories are told of hunting parties sent out from the forts in Texas to get fresh meat for the men, who, after a few days, returned with a wagon loaded with turkeys.

On the far-stretching and often level plains of Texas turkeys were frequently coursed with greyhounds. A troop of riders, with a number of dogs, rode in a long line over the prairic, beating up an extent of country half a mile or more wide. Finally, from some little hollow or clump of bushes a brood of turkeys was started, which took wing and flew, fast and far, over the prairie. The dogs, accustomed to the sport, followed some particular bird, and all the horsemen, plying whip and spur, followed the dogs at top speed. The turkey's flight was swifter than the speed of the 'dogs, and after it had gone half a mile or more it slanted slowly down to the ground and then raced away with great swiftness; but the eager dogs soon overtook it, and forced it to wing again. This time it once more gained distance on the dogs, but now its flight was much shorter than before, and once more it came to earth. The third time, tired by its previous 
flights, it rose with difficulty, and the dogs were almost under it, looking up, and now and then one of them springing high in the air in an endeavor to seize it, which at last one of them did.

A graphic account of this sport, written by the late Elliot Roosevelt, is given by Theodore Roosevelt in his very charming book, "Hunting Trips of a Ranchman."

In old times, when turkeys were plentiful, and especially in the South, they were trapped and slaughtered in considerable numbers. The commonest form of trap was one formed of rails piled up, crossing at the corners so as to make an ordinary rail pen. From this a deep trench was dug out, slanting up to the level of the ground. This trench was deep enough and wide enough for a turkey easily to pass through. Within the trap a little brush was thrown over the trench, close to the rails. Then through the trench, and running out some distance into the woods, was laid a trail of corn. Turkeys wandering through the woods found the corn, began to pick it up, and followed it to the trench, and down the trench into the pen, where more corn was scattered. In this way half a dozen turkeys, or even a whole brood, might enter the pen. When they had eaten the corn, and wished to go away, they walked around the walls of the pen looking for a place to get out, walking or jumping across the trench, but never seeming to think of going out the way they had come in. In this manner large numbers of turkeys used to be caught. 
Audubon says that sometimes, after people had become surfeited with the flesh of turkeys, they failed to visit the traps which they had baited for some time, and so the poor birds were allowed to starve to death.

Another means of slaughtering turkeys, of which we read, is by laying a trail of corn in some place where turkeys congregate; then, hiding near at hand, the gunner prepares to shoot at their heads and necks when all are busily engaged in picking up the corn.

In April, I900, E. W. Nelson, the distinguished field naturalist of the Biological Survey, described a new sub-species of wild turkey from Arizona, under the name Melcagris gallopavo merriami. This bird is found in the mountains of Arizona, western New Mexico, and south as far as the Mexican border, extending north into southwestern Colorado.

Little has been written about this bird, which presumably does not differ in habits from its relatives. Because it is so little known, we are glad to quote an account written by E. A. Goldman, who secured for the Biological Survey the specimens from which $\mathrm{Mr}$. Nelson described the subspecies.

$\mathrm{He}$ has been Mr. Nelson's companion on many expeditions, and in the Auk, in 1902, described a trip he made into the Mogollon Mountains of northern Arizona to secure a series of wild turkeys. He started in January, I900, and was very successful. The weather was cold, and promised snow, which raised the collector's spirits, since, of course, with snow on the ground turkeys would be more easily tracked and 
found than if the ground was bare. They camped upon a ridge separating Clear Creek Canyon and some of the upper branches of Canyon Diablo, and from here we will let Mr. Goldman tell his own story:

. "The first turkey tracks were seen in spots of soft soil among the piñons, soon after noon, and others we crossed at intervals along the road. Late in the afternoon, when near the upper edge of the piñon belt, we entered what was evidently the feeding ground of a large flock, for many tracks were seen crossing the wagon road in several places. This encouraged us to camp near here, and when we came to a trail leading down into Clear Creek Canyon, and indicating accessible water, we did so. After a few hasty preparations for the night the camp man was sent to the bottom of the canyon, over a mile away, to water the horses and fill casks for camp use, while the hunter and I started out in opposite directions to look for turkeys. I walked slowly and as quietly as possible through fairly open pine and piñon woods, following a half-circular course in order to avoid going too far from camp so late in the day. Many tracks were seen, but none of them had been made that day. At the end of an hour or so I came to the head of a small side canyon, about a mile from camp. The sun had just set, and all nature seemed to have gone to sleep. Not a sound broke the silence, except the slight, unavoidable rustling of my own footsteps among the dry leaves. I stopped a moment to listen, and had about decided to cut across to camp, when suddenly, from down the 
canyon, came faint but unmistakable turkey notes, which started me on a run in that direction. A few minutes later I cautiously approached the place, where probably over a hundred and fifty turkeys, all females and young of the year, were noisily trying to settle themselves for the night. They occupied the tops of tall pines for about two hundred yards along one of the steep walls of the canyon. In many of the trees there were only two or three turkeys, but some of the larger ones, and especially those with many dead branches, contained from five to ten birds. Many of them sat as closely together as possible, and constantly craned their necks about, squawking, crowding each other, and struggling for places. They flew frequently from tree to tree, and sometimes a bird alighting clumsily on a crowded branch would knock off one or two others, which would fly noisily to other places. At first the disorder seemed to be general, and most of the birds were crowding, or being crowded, and were uttering loud cries of quit, quit, quit, with many modulations, depending apparently upon the degree of excitement. They rapidly became quieter, however, until by the time it was dark they were settled for the night. When all was still I rose from the cover where I had been concealed, and carefully noting the locality, left the birds undisturbed, and picked my way across several small canyons into camp. The hunter came in soon afterward, and a comparison of notes showed that we had located the same roost, he having come up the canyon, while I went down, and each had decided 
to watch until dark, and not to begin to fire without the other. About nine o'clock we returned to the place. The first few shots, fired rapidly, created a great commotion, and the air seemed to be filled with turkeys, flying heavily off in all directions; but there were no outcries, and in a few minutes all was quiet and no more birds could be found. I was satisfied, however, that we had secured as many as necessary for specimens, though we did not know the exact number, for some of them went thumping down to the bottom of the canyon and others fell at some distance.

"At daylight next morning we were again on the ground, and found the flock broken up into small parties, which soon left their roosts and went off in various directions. On leaving the trees the turkeys usually flew two or three hundred yards and then ran rapidly until out of sight. During the following days it became evident that all the tracks seen for several miles about our camp had been made by this flock. No more fresh ones were found in the vicinity, showing that the frightened birds had left the locality at once.

"Our lucky night hunt having given us a fine series of females and young of the year, we then devoted our attention entirely to the old gobblers. We hunted steadily day after day, covering the country for miles in all directions, without seeing any of the old fellows; but they were in the country, and it could only be a question of time until we found them. From the tracks of the different flocks it appeared that the old males 
were living apart from the females and young. Females and young were seen several times, but were not molested. Evidently these birds wandered far and wide, for tracks a day or two old were often found along some ridge, and no fresh ones were seen in the vicinity for days. It did not appear that the birds returned regularly to the same roosting place. Several old roosts were found, usually among tall pines, near the head or along the walls of some side canyon, which were evidently occupied occasionally. None appeared to have been used very long, and at least two had only been occupied once. The birds spent the day wandering over the broad and gently sloping ridges between the canyons, and as evening approached worked toward one of the canyons and roosted wherever night overtook them.

"Finally, on the ninth day, soon after noon, I came upon some big gobbler tracks, which were evidently only two or three hours old, and decided at once to follow them. There were about fifteen of the old fellows, and in crossing patches of soft soil they left a broad trail, which became very indistinct, or disappeared altogether, on rocky ground. I had gone only a short distance when my hunter, whom I supposed far away, came up. He had found my moccasin tracks following the turkey trail, and quickly overtook me. I was very glad to see him, for it was difficult work, and even with our combined skill at trailing we made slow progress. Sometimes we had no trouble for several hundred yards, then suddenly we came to places 
where the birds had paused to feed, and found they had wandered about in all directions, spreading among the leaves. At such places the trail became so involved that it was difficult to find the direction taken when the birds left. When we came to hard or stony places a few misplaced leaves or an overturned stone or stick were the only things to guide us. Where the trail became dim one of us usually went a trifle to the right and the other to the left, so that unless the flock changed its course abruptly, one or the other was pretty sure to find some signs every few yards. Occasionally we lost the trail altogether and had to go ahead and to 'cut other tracks' in softer ground. For a while the course followed was very crooked, and several times it even doubled back and crossed itself, but late in the afternoon it became evident that the flock was working toward a branch of Clear Creek Canyon. Shortly before sunset the trail became so fresh that we kept a sharper lookout ahead, expecting to sight the flock at any moment. It was still proceeding in a leisurely manner, as was plainly shown ${ }^{\circ}$ by the number of places where birds had paused to scratch out deep pits in search of food. At sunset we were quite close to the canyon, and I began to fear they would be able to roost before we could overtake them. With the idea that I could hear for a considerable distance the heavy wing strokes they would make in rising to the roost, I decided to go ahead and listen, leaving my companion to follow the trail as best he could. I had only advanced about two hundred yards, to some higher 
ground, when I suddenly saw the flock, only about forty yards to my left. The birds had not seen me, and were walking quietly along in single file, following a course directly parallel to the one I had taken. They presented a fine sight, and I was strongly tempted to shoot, but on second thought decided to follow them until they roosted. Moving quietly out of sight in a small arroyo, I ran back a short distance and gave a low whistle, when my companion soon overtook me. Together we followed the birds, using great care not to show ourselves. Food had ceased to interest them, and they were evidently looking for a place to roost. They continued in single file, pausing occasionally to look warily about, until they reached some high ground overlooking a small canyon, along the slopes of which stood several tall dead pines. The leader, a fine old fellow, of unusual size, stopped, and the rest of the flock came trailing up, and gathered in a group facing the canyon. Several low, tremulous single notes, quir-r-r-rt, quir-r-r-rt, quir-r-r-rt, were uttered, and suddenly they took wing together and flew almost horizontally out to the branches of the dead trees. After leaving the ground no sound was heard except the heavy flapping of wings. A few moved into the tops of live trees a short distance farther down, but most of them remained in the dead ones. Their behavior was in marked contrast to that of the females and young. There was no crowding and no confusion, and in a remarkably short time they were settled for the night and all was quiet. From where I was lying 
their bodies appeared in the gathering darkness like enormous black fruits outlined sharply against the glowing western sky.

"When it became thoroughly dark we cautiously approached the trees and took a stand almost under one containing several birds. They were perched two or three feet apart, so that only one could be shot at a time.

"As we knew the old fellows were very wary, we held our guns in readiness as soon as we came within range, and prepared to shoot at the first sign of alarm. I sent my companion to the next tree, and told him to give a low whistle when he was ready. I held my Io-bore gun leveled at one of the birds, and it began to feel very heavy before the signal was given. When it finally came I fired both barrels in quick succession, and was much gratified an instant later to hear a crashing noise among the branches as two fine old gobblers came tumbling down, landing before me with a loud thump. Instantly heavy wing strokes could be heard in all directions as the frightened birds left their perches. My companion had also made successful right and left shots into his tree. After some search we each located and killed another turkey, after which no more could be found. We then gathered the big birds together, swung them well out of reach of prowling coyotes or mountain lions, and started for camp. When about a quarter of a mile from the roost I saw by the dim moonlight a turkey form among the branches of a big pine. A chance shot was 
made at it, and I was more than half surprised when another big turkey came crashing down. To reach camp we had several deep, dark canyons to cross, without trails, and floundered about, finding the usual obstacles, which are unconsciously avoided in daytime, but are always encountered at nigint. We were in a cheerful frame of mind, however, and above noticing small bruises and other mishaps.

"The next forenoon we spent taking pack horses to the roost by a circuitous route and bringing our game to camp. In the afternoon we started on our return to the railroad, and camped in the piñons. The snowstorm we had hoped for until it could no longer serve us came during the night, and the morning found everything white and cold outside our tent. We made a hurried breakfast, and after a long drive reached Winslow in the afternoon.

"The result of the trip was a series of thirteen specimens, including adults of both sexes and the young of the year. When specimens reached Washington Mr. Nelson found they represented an undescribed subspecies, which he named Mcleagris gallopavo morriani.

Merriam's turkey ranges in summer over the higher slopes of the Mogollon Mountains. In winter, and especially when the snow lies over the summits, the birds move down to the piñon belt, where food is abundant. I found them feeding largely on the nuts of the piñon (Pinus cdulis). According to some of the old hunters, they also eat the berries of the cedar ( $J_{u m i}$ perus utahensis), but none were found in the stomachs 
446 AMERICAN GAME BIRD SHOOTING

examined, although the turkeys, just before being killed, had been wandering through the upper edge of the cedars, where the ripe berries were exceedingly abundant." 


\section{AIDS TO SHOO'TING}

Many excellent books have been written on the art of shooting, and yet it will be obvious to any one who takes the trouble to think a little, that no one can learn to shoot merely by reading books about it. The act of shooting is a complex operation, calling for close attention and the coördination of a variety of functions. Comparatively few people become really skilful, because few practice shooting enough to bring about this co-ordination. Most of us remain beginners all our lives. Many parts of the body are called into action in discharging a shotgun: hand, arm, frame, eye and brain must all act together to make the operation perfect, or nearly so. If any one of these factors fails the act is incomplete.

The way to learn to efficiently perform a complex operation is to repeat it many times. In other words, we learn how to do things by doing them over and over again. A player of instrumental music must practice many hours a day before he can play swiftly and correctly. A person learning how to use a delicate tool must work with it a long time before he can accomplish satisfactory results. The professional shooters-men hired by the great arms or ammunition companies to go about to all the shooting tournaments and use the products manufactured by these companies-devote 
their lives to shooting, and are as skilful as any men can be; yet, in fact, it is the rarest possible exception when these men make perfect scores.

I suppose that there is no shooting practice so good as to take the gun, say twice a day, for five minutes in the morning and five minutes in the evening, and throw it up to the shoulder, aiming at different objects near at hand, and trying to catch the sight as quickly as possible; in other words, to try to throw the gun up as nearly as possible in the line of sight. If this is done often enough it will prove the greatest aid in shooting, and will tend to make shooting more rapid and more accurate.

Upland shooting may be divided into two branches, open shooting and snap shooting. In the first you see your mark clearly, and aim at it; in snap shooting you use only the "eye of faith," shooting at a shadow, a sound, or a moving leaf, and trust to Providence that your gun is so aimed that the bird which you know is there shall fly into the circle of the shot. Obviously, open shooting grades into snap shooting, and no hard and fast line can be drawn between the two. Some men, who are especially talented, practice snap shooting at all times, in the open as well as in cover.

In open shooting, as, for example, where the prairie grouse are found, or quail are scattered in the open fields, there is almost always plenty of time to take deliberate aim and kill your bird before it is out of reach. In the brush, however, where snap shooting must be practiced, because the game is hardly seen, and its 
whereabouts, distance or direction must often be guessed at, there is no time at all. The writers on shooting of many years ago laid undue stress on snap shooting, and their books seem to urge the sportsman just entering his novitiate to get his gun off first and learn how to aim at his game last. This, of course, makes a quick shot, but in these days, unless one shoots constantly at the traps, the opportunities for practicing shooting are so very few that a man might live beyond the allotted three score years and ten without ever shooting at birds enough to learn how to hit anything.

I believe the way to learn the fundamentals of shooting is to practice with an empty gun until you have learned to throw the gun up in the line of sight; in other words, make your body landle your gun mechanically, so that when you put it to your shoulder it will point in the direction in which you are looking. If you can do that you will have advanced far on the road toward making yourself a good shot.

In open shooting there is usually abundant time to take aim. If the bird gets up anywhere near you, you have time enough to fire both barrels at him and then to stand and watch him for a second or two before he is out of range. Now, if you had given one-quarter of a second more to the effort to secure a good aim on each of these shots you probably would have killed the bird with the first or second barrel, instead of enduring the mortification of a miss. The operations of throwing the gun to the shoulder and pulling the trigger take very little time, and although the bird appears 
to be going very fast, and seems likely to get out of shot before you can pull the trigger, this apparent swiftness of flight is due partly to the nervousness of the shooter. Where the shooting is open there is always, or almost always, abundant time to point your gun just where you want it. Most of the shots that are missed are due to overeagerness, which means undue haste. The shooter may feel perfectly certain that he will miss his bird unless the gun is pointed very nearly straight at it. The shot spreads over a circle of three or four feet in diameter, and sometimes, even if the gun is not pointed straight at the bird, the edge of the charge of shot will hit it and perhaps knock it down; but this is a chance not worth considering-the bird should be hit with the center of the charge. It was, perhaps, Frank Forrester who spoke of "deliberate promptitude," and this deliberate promptitude is one of the secrets of being a successful and a good shot. After all, this merely means coolness and training, the keeping of one's wits about him all the time, and never being disturbed or flustered by any event of the field. Many of the best and most experienced shots never reach the point where they can hear birds get up all about them without quickened heart-beats and jumping nerves, yet many of them never show by their shooting that they are discomposed by the noise.

It has been my experience, on a number of occasions, to go out with people who had done little or no field shooting, and I have found that a word of caution, the mere warning, "Take your time," when a bird rose, 
or was expected to rise, helped many a man to retain his self-possession and to kill birds that otherwise he would have missed, firing the gun when they were so close to him that if the charge had hit them they would have been torn to pieces. In ways such as this the man of experience may greatly help the novice without in the least hurting his feelings or in any way offending him.

In his admirable little book, entitled "Hitting vs. Missing," Mr. Hammond recommends practice by the novice at stones skipped over the smooth surface of a body of water. The suggestion is an excellent one, for the striking of the shot on the water enables the shooter to see precisely where he is holding with relation to the mark at which he is shooting. This, of course, is what each gunner wishes to know when he shoots at any object. Why did he miss? Did the charge go above, below, or to one side of the mark? The shooter who could tell where each charge of shot went, and had intelligence enough to apply this knowledge to each subsequent shot, would speedily attain a high degree of skill.

It is generally known that a person properly placed can see a charge of shot flying through the air toward a target. The charge of shot, as it flies through the air, is said to look like a long shadow composed of many lengthwise strips. It is a common practice for a trap shooter, when he finds that he is frequently missing his targets, to ask some friend to stand near him and watch where the shot is going with relation to the 
target, whether under or over, before or behind. Given this information, the shooter corrects his aim accordingly.

The many books that have been written on shooting give hints and suggestions which are of great value to the young gunner, explaining what he should do, and, more important than all, cautioning him against the mistakes he is likely to make. This is helpful, but, after all, nothing can take the place of practice. Each beginner must necessarily go through the school of preliminary practice, finally coming to clay targets, thrown from the trap, which afford the best practice of all. He may feel sure that the more practice he has the better he will learn to shoot, but I believe that the best practice of all, if it be faithfully continued, is that taken with an empty gun, for five minutes at a time, two or three times a day, throwing up the gun on different objects and pulling the trigger the instant the sight is caught; or throwing up the gun and then swiftly swinging it on to some mark and pulling the trigger just as this mark is reached.

A point that must be remembered, and that has much to do with success in shooting, or the lack of it, is the disparity in strength and skill which exists in the two arms of all men. Most men are right-handed, and are constantly performing various tasks with the right hand and arm, which thus becomes far more efficient and much stronger than the left. A few people are ambidextrous, and can use either hand indifferently. A few men are left-handed, and can shoot from the shoul- 
der, drive a nail, or write a letter with the left hand, but cannot use the right hand efficiently. Now, with the average right-handed man, shooting from the right shoulder, the gun is supported, and, more important still, is guided by the left hand; yet, as the man is unaccustomed to performing tasks with that hand, he has far less control over its movements than he has over the right hand. If he swings his gun to try to point it at a certain object, he is likely to swing it too far, or not far enough, or above or below the object.

It becomes important, then, for the man who is training himself to shoot well to endeavor to strengthen and to train the left arm so that he may have it constantly more and more under control, and thus may make it do more exactly the things which he wishes. Such strengthening and training may be begun by the use of dumbbells or the swinging of Indian clubs, which will give strength to the muscles, and then by the performance of simple tasks with the left hand, which will teach it to respond better to its owner's will.

Professional shooters, who are among the very best shots in the country, find it necessary to the performance of their work that they should keep themselves in the very best physical condition. Many of them practice constantly at gymnasium work, including dumbbells and Indian clubs, are careful about their eating and drinking, and are, in fact, trained athletes. In order to do the work for which they are paid they must be in good physical condition, and if they are 
unable to continue to do this work their services are no longer required by the people who hire them.

In old times the best shots that we used to know were the market shooters. Many of them were men who worked at some trade when they were not shooting for a living, their muscles were hard, their health good, and they were in the pink of physical condition. When they took up their guns in summer or autumn they shot all the time, and their constant practice, together with their strength and hardiness, made them most destructive of the game they followed. In the same way to-day, we find that the best shots along the south Atlantic coast are the gunners who shoot ducks for the market. Farming during the spring and summer, fishing in late summer and early autumn, and gunning through the autumn and winter, they are always in splendid condition, and always in good practice.

Very different is the case of the city or office man, who perhaps spends fifty weeks of the year at his desk, walking each day only a few blocks. When his vacation comes he sets out on his shooting trip, and is surprised and disappointed to find that he can neither tramp nor shoot. Why should he be able to do either? It is not by doing a thing half a dozen times a year that one acquires skill in it. The man who is to undertake tasks requiring skill, muscular effort, long wind, or endurance of any kind, must prepare himself for the task which lies before him.

As I wrote some years ago, in "American Duck 
Shooting," "Skill in shooting is not born in any one. Just like reading and writing, it must be learned; and, like reading and writing, the more practice one has the more easily and better it is done. Many a professional gunner who is a wonderful shot would find it labor of the hardest kind to sit down and write a four-page letter; and many a business or professional man, who goes gunning perhaps once in two or three years, finds that killing the fowl that give him shots is something that he cannot accomplish. Many men have noticed that sometimes at the end of a season they can shoot very well; and then, if for two or three years they do not go shooting, they find that they cannot hit anything, and have to begin at the beginning and learn it all over again. They have, perhaps, forgotten how to hold on their birds, and besides, their muscles, through disuse, refuse at first to act with the brain as they formerly did. This reflex action, so called, can only be regained by practice."

From the books on shooting much may be learned about how to hold on straightaway birds, incomers, quartering birds, and cross shots. It is well to remember that at twenty-five or thirty yards the charge of shot from a cylinder-bore gun covers a circle two or three feet in diameter, and that on quartering birds, and those flying across one at such a distance, a certain allowance may be made for the great area of the charge. 'In other words, if the shooter fires one foot ahead of a crossing bird it will be quite certain to fly into the load. If the shooter fires a little behind the 
bird, very likely it will be missed altogether, or only the edge of the load will prick it. Birds fly fast, but shot flies much faster, and while almost every one is likely to shoot behind wild ducks, there is very much less danger of doing so on cross shots at upland birds.

In the brush shooting which prevails over many parts of this country the birds usually get up very near to the gunner, and the shooting is quick and close. A cylinder-bore gun and a charge of small shot will give better results for this shooting than a choke-bore gun and large shot. I usually begin the season by using one ounce of No. Io shot for woodcock, partridges and quail, but as the weather grows colder and the leaves fall, the birds are likely to be wilder and to be a little more heavily feathered, and for the very last of the season an ounce of No. 8 shot may be used for quails and partridges alike. In prairie shooting, toward the end of the season, when the chickens have become wild and get up at long range, heavier shot and a choke-bore gun may profitably be employed. Sage grouse, being very large and-the old ones-very tough birds, may be shot at with No. 6 shot all through the season.

In all shooting there is really nothing more important than that the gunner should know just what his arm can do. If he thoroughly understands this, if he will practice as recommended, and if he has his nerves and impulses under good control, he can very soon make of himself a more than average shot. 


\section{CLOTHING.}

The hunter's comfort and endurance are largely dependent on being properly equipped in the matter of footwear and clothing. The average novice is more than likely to be ill furnished in these essentials, even though he be expensively furnished. For instance, clothing which is too tightly fitted, or too heavy in weight, adds unnecessarily to the strain of walking or riding, thereby inducing premature fatigue, and meanwhile cramping the activity and lessening the enjoyment. The clothing should always be loose enough to admit of the freest movements of the limbs, the matter of style being a secondary consideration from a common-sense viewpoint.

Proper footwear is also of prime importance, for while the walker may proceed passably well with a hampering fit as to clothing, he is at a constant and painful disadvantage if he wears ill-fitting shoes. The latter are sure to strain, chafe or blister the feet, so more or less crippling the wearer and marring his enjoyment. When the feet are sore the walker, in the attempt to save his feet, is thrown out of his usual stride, and this lack of balance throws strain on weaker muscles, bringing on a general soreness of the body, with the result that what should be a recreative pleasare becomes a painful labor. 
The hunting field is no place for the breaking in of new footwear. The latter should be purchased months ahead of its actual use afield, and should be worn often enough to be thoroughly broken in, so that it may be worn with comfort in actual hunting.

The footwear should be as light in material as is consistent with practical use. If the going is easy and dry, the hunter may advantageously use some of his old cast-off shoes, assuming, of course, that they have some wear left in them. About two dozen hobnails, driven in proper distribution in the soles and heels, add greatly to their efficiency in walking, and protect them from the grinding and cutting effects of rocks in rough going. It should be observed that the hobnails are an indispensable adjunct to any hunting footwear. In dry weather the soles of the boots or shoes take on an exceedingly slippery polish, so much so that walking on dry leaves or grass in shoes without hobnails presents the same difficulities as walking on ice.

The specially manufactured hunting boots and shoes are made of various kinds of excellent leather, heavy and light, and in styles to suit the fancy of the purchaser. The best makes have tough, pliable uppers, strongly reinforced on the sides, double-soled from toe to heel, hobnailed; soft and elastic as a whole, yet so closely constructed, withal, as to be nominally waterproof, comfortable and durable. The boots, as a rule, are simply the shoes with a leg added, and they weigh more accordingly.

After all, lightness of weight in foot gear is a most 
important consideration, and many sportsmen of great experience wear only low shoes with canvas leggings of the cavalry type. Some men wear tennis shoes with leggings, and rejoice greatly in the ease with which they can get about, walking down their more heavily shod companions. Of course, tennis shoes wear out, but on the other hand they are much less expensive than heavy boots or shoes. I have seen them used in big game hunting in the Rocky Mountains.

The footwear should be selected with a consideration of the surface features of the ground on which it will be used. On comparatively smooth ground a light shoe can be worn with advantage, but on ground where rocks and ledges are numerous a heavier shoe is necessary to withstand the increased rough usage.

The only advantage of the boot is that the leg serves as a legging; but it has the disadvantage, which the regtular legging has not, that in warm weather, owing to the tightness, and absence of ventilation, it causes overheating and much discomfort. It also hampers the free movement of the ankle.

The combination of shoe and legging is much lighter than the boot, is better ventilated, and does not hamper the leg action in the least.

The moccasin-shoe is an excellent article of footwear, particularly in such hunting as enjoins the most silent activity. It is a kind of compromise between the moccasin and the shoe, being the former with a light but tough sole added thereto. The material, how- 
ever, as to uppers, is of the lighter and tougher leathers, such as calfskin, etc.

These, in the main, are the essentials of hunting footwear, though presented in many varied styles and of varied materials.

A city dweller, accustomed to the use of light footwear day after day, seriously handicaps himself if he wears unnecessarily heavy footwear afield, particularly if he has reached an age which can no longer be recognized as young.

An excellent leather-top rubber shoe serves admir. ably for still hunting, for hunting in wet or winter, and are strictly waterproof, but they draw the skin on perspiring feet to an injurious extent, and therefore, for certain persons, are not a proper article of footwear.

As to clothing, there is even a greater variety as to style and material from which the hunter may select. Of the materials offered, corduroy, moleskin and canvas have held conspicuous place in the garments used in upland shooting, though severalıother kinds of material also have strong claims to excellence.

However, in upland shooting, any material having a woolen admixture is quickly picked to pieces by brush, briars or heavy grass, and does not possess the peculiar advantages of the aforementioned cloths, which are of cotton material, hard in finish, and of great durability.

Khaki and Duxbak are very superior cloths for hunting garments. Advantages of canvas are that it dries 
quickly, keeps out heat and cold, will not hold burs, and is cheap and durable.

Jackets made of various kinds of skins are excellent protection in cold weather. They are light, pliable, impervious to wind, have a smart appearance, though, as a rule, the upland shooter rarely needs overclothing for the sake of warmth. His exercise keeps him warm. Still, at the end of the day, if the hunter rides home, he needs protection from the chill of evening, and should have an overcoat in reserve for his comfort. One weight of outer clothing will serve for all seasons, hot or cold.

The shooter can meet all requirements as to weather by selecting his underwear, light or heavy, according to the temperature.

If the shooter desires to provide against stormy weather, he can find a large variety of storm coats, light and heavy in weight, made of rubber, oilskin and Duxbak, the latter being a canvas partially waterproof. If the shooter desires a raincoat for use on horseback, he should be careful to so specify, as one not divided in the back to a proper height so that it may spread over the rider's legs, will not be a protection from rain. 


\section{GUNS AND LOADS.}

The selection of a gun is a matter which requires careful consideration. Weight, bore, and shooting qqualities are not to be determined arbitrarily.

As a rule, the novice desires the closest shooting gun obtainable, regardless of whether it is appropriate to the shooting he expects to have, or whether his skill is equal to the exactions of such gun, be the shooting what it may. Even superior marksmen are prone to use guns of too close pattern and loads of unnecessary power. If the shooter cares to own but one gun, and uses it for all-round shooting, a compromise as to weights, loads, etc., is desirable, though for cover and open shooting special guns are quite the best, a modified cylinder for the one and a closer choke for the other.

Whatever the bore, the gun should be as light as is consistent with safety. An extra pound or two of gun counts heavily in added weariness toward the end of a day's shooting, and at all times in the way of slower manipulation. Quickness of execution is one of the prime essentials in the practical use of the gun in wing shooting.

In the closing years of the past century the popularity of the Io-bore rapidly waned, till at last it became obsolete as a gun for upland shooting. In weight 462 
it ranged from 8 to 12 pounds, and, as a rule, was chambered for heavy loads; that is, from 4 to 5 drams, sometimes more, of black powder and $\mathrm{I} / 4$ ounces of shot. The advantages of the ro-bore were in its capability to handle heavy loads, and it is an excellent gun for duck shooting and for prairie chicken shooting late in the season. A light Io-bore, shooting light loads, is opposed to the principal reason- that is, the capacity for shooting heavy loads-which justifies its use. It was demonstrated, after a number of years, that the Io-bore had very little advantage in ballistic properties over the 12bore, but had the very serious disadvantage of extra weight and more expensive ammunition.

At present, bores smaller than I2, as I6, 20 and even 28 , have their warm advocates, who present many cogent reasons for their faith. However, for all round shooting purposes, the 12 -bore is still the popular gun. In weight it runs from 6 to 8 pounds, or more, with barrels of 26, 28, 30, 32 and 34 inches, 30 inches being the favorite length. It is chambered for from a $2 \frac{1}{2}$

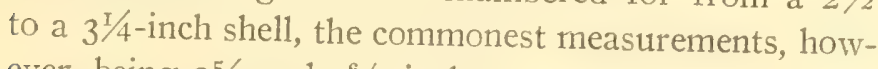
ever, being $25 / 8$ and $2 \%$ inches.

The lightweight gun uses a lighter load, there being always a proper relation of load to weight of gun. If the gun is excessively light, then its advantages in the matter of handling a heavier load are lost, and it is better to get a gun of smaller bore. The load for the 12-bore ranges from 2 to 4 drams of bulk powder, according to the weight of the gun and the 
kind of game bird on which it is employed. Four drams, however, is an excessive load, used chiefly by pigeon and duck shooters, and by very few of them. Besides the punishing recoil, the excessive load strains a gun seriously and shortens its life.

The most desirable all-round load for a 12 -bore is 3 drams of powder and $I / 8$ ounces of No. $7 \frac{1}{2}$ chilled shot. This is a very killing load, and is in general use by target shooters at the traps. However, for special shooting, different sizes of shot are essential.

Some shooters use $3^{1 / 8}$ or $3^{1 / 4}$ drams of powder, but the recoil is much greater, relatively, than that of 3 drams, and punishes the average shooter. The recoil may be kept within reasonable limits by reducing the weight of shot as the load of powder is increased; thus, $3 \frac{1}{2}$ drams with I ounce of shot gives a high velocity, and is very effective in duck shooting, at the same time being free from excessive recoil.

The only advantages of bores smaller than the I2 are their lightness, and the consequent greater ease in carrying them and greater quickness in aiming, because of their greater lightness. The ammunition for them is somewhat cheaper, but not enough so to be a matter for serious consideration. While the smaller bores will deliver the load of shot with as much velocity as the larger bores, it should be noted that the killing circle is less, and that, therefore, a higher degree of skill in pointing is a necessary correlative. If the bore is such as to make the killing circle equal, then the pattern is thin. Thus there is reason, while giving con- 
sideration to the powers of the gun, to consider therewith the capability of the shooter.

Some shooters have a false pride concerning the ownership of a cylinder bore, which is often assumed to indicate inferior shooting qualities in the gun or lack of skill in the shooter; but it is far more sensible for the shooter to use a gun in accord with his shooting capabilities, and the conditions as to cover shooting, etc., and thereby achieve reasonable success in the field, than it is to make a ridiculous failure with a gun which shoots too close.

A full-choke gun puts about 70 per cent. of the shot in a 30 -inch circle at 40 yards, a half-choke about 60 per cent., a quarter-choke about 50 per cent., an improved cylinder 45 per cent., a cylinder-so called; it commonly has a trifle of choke in it-35 per cent.

It is a safe assumption that by far the greater number of birds, in upland shooting, fall within 25 yards of the shooter; therefore, the pattern made at 40 yards is not the criterion by which to judge of the gun's powers at 25 yards. In cover shooting, a full-choke gun mutilates many birds to a degree which renders them worthless.

Some shooters have a I6-bore set of barrels fitted to a 12-gauge frame, the barrels being correspondingly heavy, the greater weight necessarily being about the chambers; thus this greater weight negatives all the advantages of the I6-bore in the attempt to shoot heavy. loads.

Again, the 20-bore, mounted on a 16-gauge frame, 
is another freakish perversion of the smaller bore, though the fads and fancies of shooters are of much trade value to the gun makers and repairers.

The smaller bores can rarely be used to advantage with less than a quarter choke, it being obvious that three-quarters of an ounce of shot should be held closer together than an ounce and a quarter to insure a proper distribution in the pattern.

The 28-bore is a wonderfully effective gun for upland game shooting, and its lightness makes for quick execution; but the killing circle is relatively small, and a higher degree of skill is a requisite in its successful use.

The 16-bore, 26,28 or 30 -inch barrels, may weigh from $5 \frac{1}{2}$ to $63 / 4$ pounds, and the 20 -bore may have about the same range in weights, with $6 \frac{1}{2}$ pounds, perhaps, as the maximum. Two sets of barrels, one set of modified cylinder bore, the other a close choke, add immensely to the efficiency of the gun.

There is no doubt but that in the matter of destructiveness the repeating shotgun, "pump" and automatic far surpass the double gun. Fortunately, at the rise of a bevy, in upland shooting, the average sportsman using such gun is not sufficiently expert to fire more than two shots with any degree of certainty. Yet, having extra loads at his command, he can take advantage of any slothful or timid birds which rise after the main part of the bevy has flown, hence is hardly ever caught unprepared.

An expert with the repeating shotgun is terribly 
destructive when in action afield. He can fire with wonderful quickness and precision, and may destroy a small covey at the first rise. Except for that feature it has no advantages over the double and single-barreled guns in such sections as have a legal limitation to the number of birds any one shooter may kill in one day. However great the destructiveness of any gun, it may not be properly employed to exceed the statutory limit. It is urged as a plea against the repeater that, its capacity to kill being so great, there is always a temptation to kill more than the legal limit; but the same argument can be urged against any other kind of gun in the hands of a skilful but lawless shooter. Men have broken the law many times while using guns other than repeaters, therefore there is nothing inherent in the kind of gun which makes for good citizenship. That is a point of ethics which refers to the man.

Factory-loaded ammunition has been so admirably improved that it is practically perfect. The average shooter, in the attempt to kill, is prone to attribute failure to faulty ammunition or to a gun which does not shoot straight or does not fit. If the shooter could calmly persuade himself to look upon his failures with the same unprejudiced opinion common among his companions in respect to himself, he could safely place the blame for all failures without any risk of creating an argument. In any event, when afield, it is not an unwise policy to keep all explanations of one's failures to one's self. Nine men out of ten do not care to listen 
to hard-luck stories, which oftenest have their origin in incompetency; and the other man, who might be sympathetic, right or wrong, is more than likely to have troubles enough of his own.

There are shooters who have a belief that they can produce better cartridges loaded by hand than those made by machinery. Such belief is fallacious. Given like materials, the machine-loaded cartridge is likely to be the better of the two. To a certainty it will have more uniform loading, as the pressures on the wadding will be automatically alike. This uniformity is beyond the compass of the hand. The kind and quality of wadding, however, is an important factor in the effectiveness of any load, hence a well wadded hand load may surpass a poorly wadded machine load; but this is a matter of material and not of methods.

For the I6 and 20 gauges the loads of shot should be comparatively light, from three-quarters of an ounce to one ounce, with from two to two and a half drams of bulk powder, or a corresponding quantity of dense powder. There should be no attempt to arbitrarily make the smaller gauges equal to the $\mathrm{I} 2$ in weight of ammunition. As already suggested, the advantage of the smaller bores is in their lightness, and therefore in their fitness for upland shooting, which does not exact such hard killing qualities in a gun as does wild fowl shooting.

The gun should be selected with a view to its fitness for the special shooting of the owner, his physical strength and skilful capabilities, which, summed up, 
are quite apart from the matter of reducing all the factors to an arbitrary standard. Any gun that is overloaded, be it light or heavy, will kick unpleasantly, and sometimes harmfully, as shown by a bruised shoulder, a contused cheek, and perhaps a cut trigger finger.

As a consequence of a punishing recoil, the shooter is quite likely to flinch or fudge, which, in turn, with continued punishment, is quite likely to become habitual, thereby greatly impairing success. The lighter the gun, the more violent the recoil from overloading.

If the shooter is physically so hardy that he can withstand the punishment consequent on excessive recoil, he nevertheless is quite likely to lose control of the kicking gun in delivering the second shot. No argument is required to show that a man in the act of firing both barrels, one quickly after the other, can maintain a perfect poise and do quick, accurate execution with a gun which does not kick, and that he cannot do so equally well with a gun which kicks so hard that it throws him off his poise. There is no arbitrary rule. Each case must be considered by itself. As a rule, a large man will withstand the recoil better than a small man. Again, some men have the ability to take most of the recoil on the hands and arms, which absorb the shock as would a spring, thereby relieving the body from the hard shock which is communicated when the gun is held firmly against the shoulder. Apart from all this, the average gun, when overloaded, does not equal its performance with its proper load. 


\section{DOGS.}

Setters and pointers are the breeds of hunting dogs which are chiefly used for work afield by American sportsmen. These breeds display especial usefulness in the pursuit of the various kinds of game birds, such as quail, grouse, snipe and woodcock. Sport of this kind is known as upland shooting, in contradistinction to wild fowl shooting, a sport of marsh and water.

Spaniels also have appreciative recognition, in a relatively limited way, by certain sportsmen whose domicile happens to be situated in a locality favorable to spaniels' use. But even at that, this breed holds such an insignificant place in relation to the gun, in America, that it may be considered as a negligible factor.

In this country the areas in which the spaniel can be worked to advantage are so few and unimportant, as compared with the vast areas favoring the work of the setter and pointer, that it is obvious that these natural conditions dominate and determine the sportsman's choice to an important degree. As few sections favor the spaniel's use, few sportsmen own him. His physical powers, compared with those of the pointer and setter, are exceedingly limited, and he is thus at a disadvantage in the comparison with them. Nevertheless, in certain areas containing much cover and irregular ground, in which the view is constantly obstructed, the 


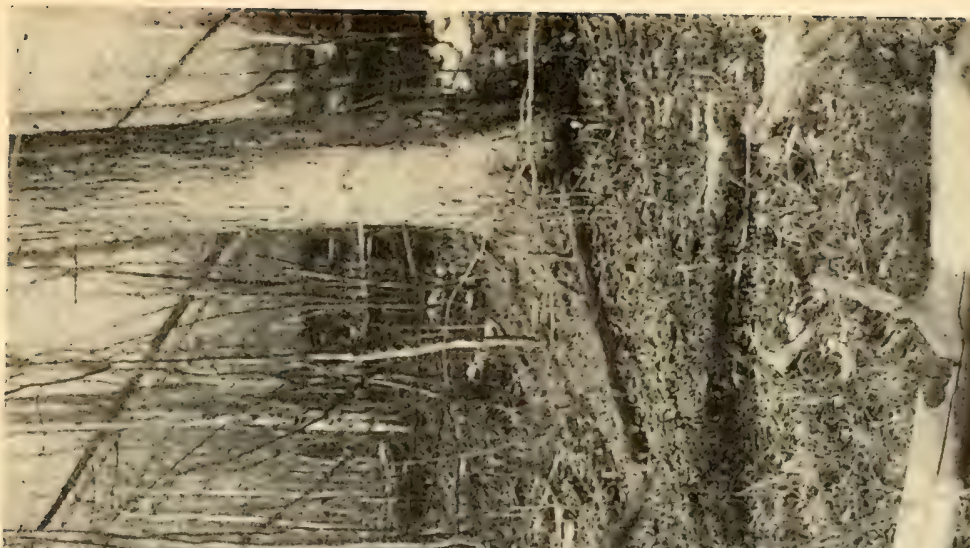

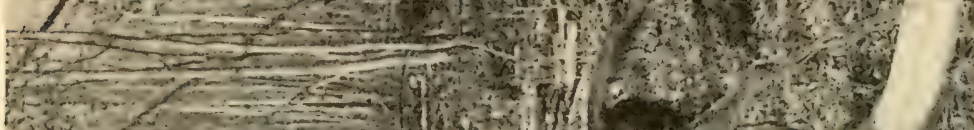

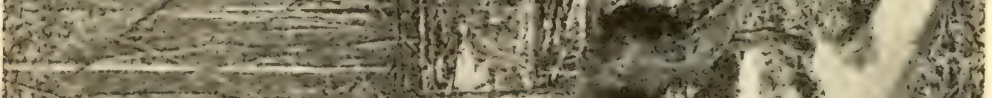

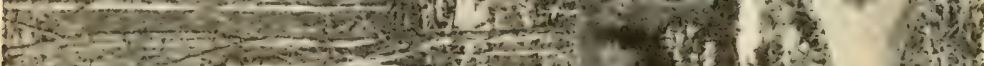

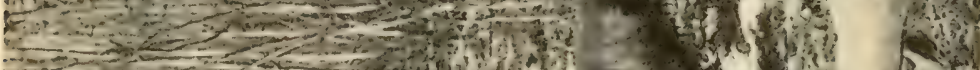

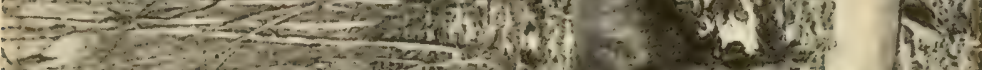
16-

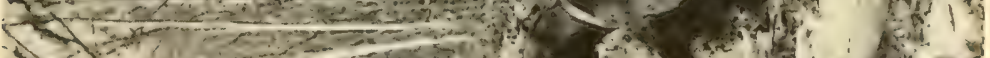

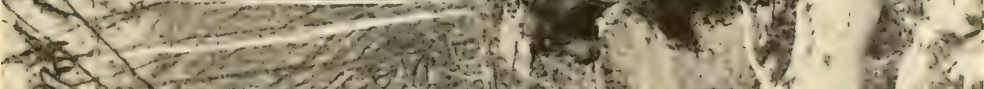

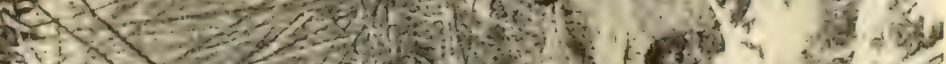

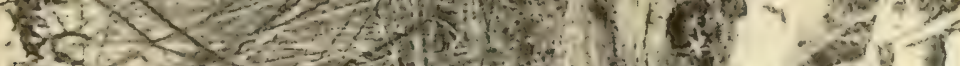

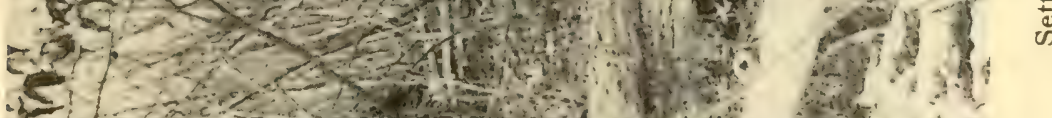

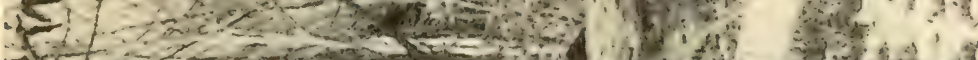

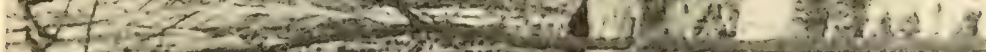

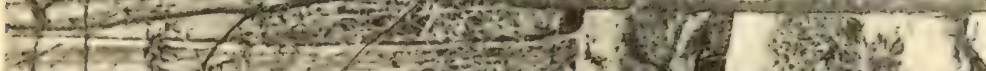

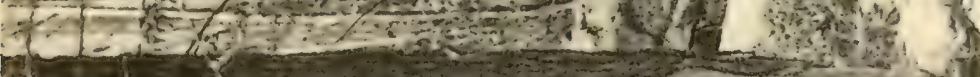

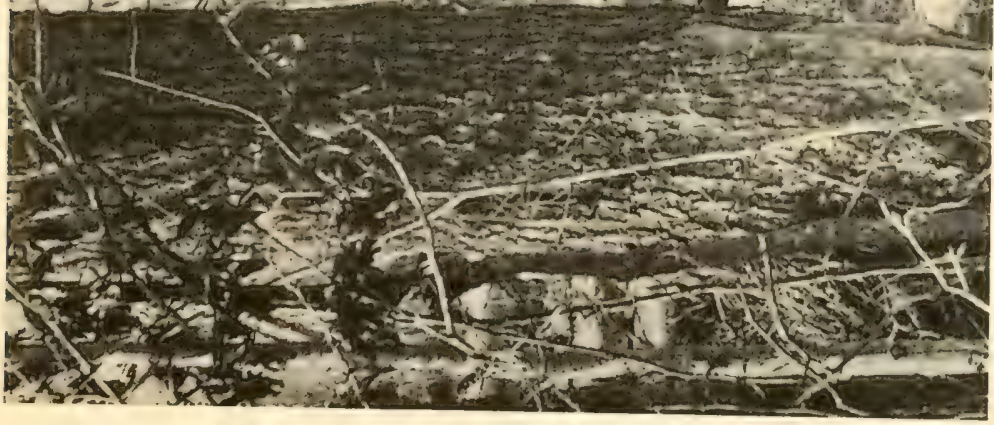



work of the spaniel fits in admirably, assuming that game is present in reasonable abundance.

The spaniel's working methods, natural and educational, are quite distinct from those of the pointer and setter. The two latter hunt mute, and, having found the birds, indicate the find by pointing them, the flush being left to the shooter's choice of time and manner. The spaniel trails the birds to their place of concealment, and, the opportunity offering, presses them to a flush without any attempt at pointing, if he acts properly; hence the term "springer."

Some spaniels whimper, babble, or give tongue merrily while trailing; others work mute. Giving tongue at all is an objectionable trait, as in upland shooting man and dog should work as silently as possible. This is especially important when the birds are wild and seek safety in flight at the slightest alarm. Thus the need of silence in upland shooting would seem to be quite obvious.

However, this is contrary to some of the traditions and usages governing the use of the spaniel afield. Stonehenge (J. H. Walsh), in his work "Stonehenge on the Dog" (I873), in respect to this matter speaks as follows: "A good and somewhat musical tongue was, by the old school of sportsmen, considered a desideratum, in order not only to give notice that the dog is on game, but also the particular kind which he is 'questing,' and which many good spaniels enable their masters to distinguish by a variation in their notes. Formerly this was thought so important that if a 
spaniel happened to be mute he was hunted with a bell around his neck, as is sometimes done with the setter when used in covert. In the present day a very fashionable breed (the Clumber) is invariably mute; but as these dogs are chiefly used in aid of the battue, there is not the same necessity for them to give notice of their approach as in the case of spaniels used either in wild pheasant shooting or for cocks, hares or rabbits. It will, therefore, appear that for every kind of covert shooting but the battue we require a strong, useful spaniel, capable of bearing exposure to the weather, and neither too large for the runs nor too small to bear work. Added to these qualities we want an exquisite nose, and a musical but not noisy tongue, which is all the more valuable if it will distingtuish by its note the various kinds of game."

While giving tongue might charm the ear of the English sportsman, and indicate the kind of birds ahead of the spaniel, in this country, with its rough, irregular coverts, much of which are in the condition that nature's hand shaped them, a noisy dog is a detriment to the sport.

As to the advantages of flushing, there are many qualifications. Considered in its proper relation as a spaniel trait, the spaniel must be trained to work well within gunshot of the sportsman. He also must conduct his efforts at all times with a reasonable degree of steadiness, to the end that the gun shall constantly have favorable opportunity. This intelligent co- 
ordination of effort between dog and gun is absolutely essential to success.

When on a trail, the spaniel should time his speed to that of the shooter. When pressing in close on the birds he should refrain from flushing till the shooter is properly placed and ready for the shot. If he is specially intelligent, accomplished and helpful, he may get the birds between himself and the shooter before flushing them, so that they may be driven toward the shooter, thus enhancing the chances for a successful shot.

It is self-evident that a lawless spaniel, ranging out of gunshot, and flushing the bircls regardless of the shooter's interests, is in no sense an aid to the gun. Such misbehavior, on the contrary, insures that even if the game be plentiful the opportunities of the shooter are constantly ruined, and he then is much worse off than if he had no dog at all.

As the spaniel is not required nor desired to point, his training is correspondingly simpler than that of the setter and pointer. When trained, he beats out a very limited area of ground about the shooter, keeping at all times well within gunshot, flushing the birds without any preliminary point as an entirely proper act. In thick cover, or in ground so rough that the dog is much hidden from view, the advantages of this manner of work are manifest.

In the case of the pointer and setter, which frequently fund birds far out of gunshot, the advantages 
of pointing, and of stanchness to the point till the gun arrives in position, are also self-evident.

By feathering, and a general change of manner and intensity of action, the spaniel indicates his recognition of the foot scent or the whereabouts of the birds. By the observation of similar mannerisms, displayed when he catches the body scent, the shooter discerns when the spaniel is close to the birds or is about to spring on them. Thus, while his preparation for efficient field work requires but a moderate degree of training, as compared with the more complex education required for the setter and pointer, it is imperative that his education, so far as it goes, shall be complete. It is obvious that in the interest of good sport he must conform to the gun's requirements.

He should promptly obey the commands, "Heel," "Go on," "Drop," "Fetch,", "Come in," "Seek dead," or "Find," and "Steady," the latter command being of special importance, since it comes into frequent use in many relations, as when the spaniel is roading too fast, or is intent on a premature flush, or when he is disposed to become riotous and generally disobedient. A proper observance of this order makes in many ways for the better success of the gun and the pleasure of the shooter; therefore, the importance of establishing thorough obedience to it.

As to methods of finding the birds, the spaniel, as a rule, follows the foot scent, differing in this respect from the best working pointers and setters, which carry a high nose to catch and follow the body scent direct to 
the birds. However, as the spaniel works in a narrow area, while setters and pointers work over considerable territory, each method, in its proper relation, has its special fitness and value.

In the matter of speed the spaniel is at opposites with his pointing brothers. His range, necessarily so limited in scope, requires but a moderate degree of speed to meet the requirements of the gun. Even with moderate effort he has ample time to search out every nook and corner within gunshot of the shooter, as the latter meanders along. With a team of spaniels -a team may be any reasonable number which the fancy or needs of the shooter requires-nothing is overlooked by them.

If up to the proper requirements, the spaniel works merrily, diligently and intelligently. He delights in the quest. A team of well broken spaniels, working in a section adapted to their peculiar methods and limitations, affords excellent sport. Unfortunately, in the United States such sections are few and far between.

In England, before the battue and driving had largely ousted the pointing dog and spaniel, the latter, as a worker afield, held an important place in upland shooting and in the esteem of sportsmen. There were many good reasons for this choice-good reasons as they pertain to English shooting, but otherwise in respect to shooting in this country. On the English game preserves the dog trainers, the gamekeepers and the owners know every cover, every range and every runway. They know where the birds most fre- 
quent, and, therefore, know how to work out every inch of ground to the best advantage.

For cover shooting the spaniel is a superior assistant. His shorter leg and smaller size enable him to pass readily through or under cover which would offer a real obstacle to setter and pointer, even if it did not deter them from attempting it. As he works within gunshot he meets an essential of close cover shooting. Flushing the birds under such conditions is a distinct advantage. Thus, then, the springer may be considered as a better worker than the pointing dog for rough and cover shooting exclusively.

It is obvious that a setter or pointer, when standing stanchly in dense cover, out of sight of the shooter, is, as an assistant, inferior to the spaniel, which flushes the birds at once. To overcome this disadvantage, some shooters tie a small bell to the collar of the pointer or setter, and when its tinkle ceases, the dog being hidden from view, the inference is that he then is pointing.

To overcome the disadvantage of pointing stanchly in dense cover, some trainers school their setters or pointers to flush to order, but such a practice tends to disorganize the dog's training as a pointing dog, as he is likely to become unsteady and unreliable in this most valuable particular.

As showing the great popularity of the spaniel in England, the following is taken from "British Dogs," written by the late Mr. Hugh Dalziel, and published about twenty years ago: "The spaniel is not only 
the oldest breed we have that has been kept to the hunting of fur and feather, as a help to hawking, netting and the gun, but he is still the most generally useful of our game dogs, as he is the most universal favorite. In field or covert, no dog works so close as a well bred and well broken spaniel; neither fur nor feather can escape him; no hedgerow is too thick, no brake too dense for him to penetrate and force out to view of the sportsman the reluctant game; he is a most active, ardent and merry worker. His 'wanton tail,' ever in motion while he quests, increases in rapidity of action with that tremulous whimper that tells so truly that he is near his game, and says to his master, in terms that never deceive, 'Be ready-it is here.'"

Referring to the ancient history of the spaniel, the same author remarks: "Spaniels were, in olden times, also known by the name of the game they were kept to, as 'a dog for the partridge,' 'a dog for the duck,' 'a dog for the pheasant,' as in our own day we still have the cocker, or dog for the woodcock; but at what date the term 'springer,' or 'springing spaniel,' was introduced, I do not know, but presume it must have been when the qualities of the setter, or 'setting spaniel,' became fully developed and permanently fixed by breeding setters from known setting spaniels only, and keeping the breed of questing spaniels distinct; the term 'springer' was probably given to them on account of their natural disposition to rush in and flush or spring the game." 
In view of his special aptitude for work in cover and rough country, the spaniel should fit in usefully in many sections of Canada, New England, Pennsylvania, etc., for woodcock and ruffed grouse shooting. Yet, even in those sections, the stretches of open game country are so numerous, though contiguous to cover, that much of the best shooting ground is beyond the capabilities of the spaniel. Thus the advantages and disadvantages average up in such a way that in the compromise as to methods the setter and pointer have the preference.

In open country, where range is an essential to success, the spaniel has no standing as a worker. As he ranges close, from compulsion, and flushes his birds when he finds them, it is quite obvious that in a prairie or open country he could not meet the requirements.

In bench show competition, and as a house dog, the spaniel shines as a favorite. Some years ago his admirers made a vigorous attempt to organize spaniel field trials in the United States, but the effort resulted in failure. However, in England, spaniel trials have been held with more or less success.

The foregoing remarks, in the main, apply to field and cocker spaniels, but there are several other breeds used for field work, chief of which are the Clumber spaniel, a dog of heavy physique, slow and mute in his work, and easily broken to work to the gun. The Sussex spaniel is a dog of hardy constitution, a good all-round worker, much prized at one time in England for his superior usefulness afield. The English springer 
is said to be identical with the old Norfolk spaniel, a compactly built dog, standing much higher on his legs than do some of the other spaniel breeds, and quite disposed to give tongue on occasion. There is also the Welsh springer, of comparatively recent classification, and there are several others as yet unnamed.

Of setters, three breeds-English, Irish and Gordon -are recognized in America.

In England, some authorities affect to recognize the Russian setter, though everything purporting to be descriptive of that breed is meager, and seems to rest largely on hearsay. Edward Laverack, in his work, "The Setter," describes them as white, lemon and white, liver and white, and black and white in color, yet naively remarks: "I have never seen but one pure specimen, which was in the possession of the late Lord Grantley, at Rannoch Barracks, head of Loch Rannoch, Perthshire." He also stated that "these dogs are but little known in this country." As a matter of hearsay, he relates that the head keeper to Her Majesty, many years ago, had a beautiful breed of Russian setters, and that "they were good, but most determined, wilful and cbstinate dogs, requiring an immense deal of breaking, and only kept in order and subjection by a large quantity of work and whip; not particularly amiable in temper, but very high-couraged and handsome; an enormous quantity of long, silky white hair, and a little weak lemon color about the head, ears and body; and their eyes completely concealed by hair." 
In "Stonehenge on the Dog" special attention is devoted to this setter. By way of illustration, a picture of "a Russian setter slightly crossed with English blood" is presented. In many points it resembles the griffon. Stonehenge remarks: "They are now very scarce in this country, of pure blood, and even the cross with the English setter is seldom seen." Many years ago Mr. R. L. Purcell Llewellin, who was sceptical concerning the existence of this breed, offered a prize for any Russian setter shown at the Birmingham dog show. None was shown in response to the inducement. The breed, if it ever existed as a breed, was thought to be extinct many years ago. More likely it was merely a cross-bred strain. The probabilities are that it never was known in Russia.

The product of a cross between the setter and pointer is called a dropper. It is considered a mongrel cross, and therefore is not recognized as a breed. However, this cross has produced useful working dogs, though even at that far inferior to the best straight-bred pointers and setters in respect to high-class performance. In certain quarters, which are without any recognized authority in matters pertaining to breeding, there is a belief that the dropper averages well and pleasingly with the setter and pointer as a worker. Well informed, practical sportsmen know that while there may be a passably good dropper now and then, their average as workers afield is not above the mediocre. There is an abundance of data concerning field work and field-trial competition which establishes the fact 
that the dogs of pure blood are far superior. In the matter of beauty the dropper has no standing.

In any event, it is admitted that after the first cross the dropper deteriorates physically and as a worker. In any generation he does not breed true to any fixed type. Perhaps he may have all the externals of the setter or of the pointer, or he may show modified characteristics of both. For instance, a pointer coat may be accompanied by a rudimentary flag on the tail, or the latter may have a bushiness foreign to true pointer type. This cross is never attempted or approved by careful breeders, and is repugnant to all true sportsmen. As a rule, the dropper is the result of ignorance in breeding matters, or of cheap pot-hunting proclivities, or he is a makeshift of indigence.

The origin of the setter is unknown. As a matter of conjecture, it is held by certain writers that his origin is in a spaniel ancestry. There is much of plausibility in the arguments advanced to sustain the assumption. In many respects, some breeds of spaniels and setters bear a striking physical resemblance. They possess many instincts in common, though differing in some important particulars as to methods of pursuit. Some spaniels at times display rudimentary attempts to point, while on the other hand there are many setters which display a natural inclination to flush birds without pointing them at all, or with but a mere pretense of pointing them. Nevertheless, the evidence adduced in support of a spaniel origin is too fragmentary and too speculative to furnish actual proof; and, more- 
over, in the ancient writings there are conflicting opinions on this point.

In "The Dogs of the British Islands" (edition of I867) Stonehenge, from such evidence as was available, reached a vague conclusion, as follows: "As some difference of opinion appears to exist with regard to Setters, we have determined thoroughly to satisfy ourselves as to their origin and best form, and we have called the best authorities to our assistance." His ipse dixit is that the Romans, after the invasion, "introduced the Land Spaniel, if not the Water Dog also, into this country" (England). He continues: "When used either with hawks or for the net (especially in the latter case), a far heavier dog answered the purpose than what we call a 'High-ranging Setter.' The net enveloped a whole covey in its meshes, and few manors would allow of many coveys being taken in a day; while the disentangling the birds and securing them allowed time for a heavy dog to rest and regain his wind." This is a labored, far-fetched attempt to account for the origin of the setter. All experienced trainers know that any kind of dog that will hunt can be trained to drop to shot, wing, order or signal, and teaching a dog to drop to scent or sight of the birds is not a difficult educational feat to encompass. But Stonehenge states that a far heavier and less enduring dog than the modern setter was used for the net, thus proving-so far as he proves anything at all-unlikeness, instead of likeness.

Stonehenge candidly confessed that he personally did 
not know the origin of the setter, in which respect he differed to an important degree from some other writers, who make greater pretensions without possessing any greater knowledge. He continues: "But in after years, as we shall see, dogs were required to point," in proof of which he quotes in part as follows, from the writings of Richard Surflet, who wrote in I600: "There is another sort of Land Spannyels which are called Setters, and they differ nothing from the former (the springer) but in instruction and obedience, for these must neither hunt, range, nor retain, more or less, than as the master appointeth, taking the whole limit of whatsoever they do from the eie or hand of their instructor. 'They must never quest at any time, what occasion soever may happen, but as being dogs without voices, so they must hunt close and mute. And when they come upon the haunt of that they hunt, they shall sodainely stop and fall down upon their bellies, and so leisurely creep by degrees to the game till they come within two or three yards thereof, or so neare that they cannot press nearer without danger of retrieving. Then shall your setter stick, and by no persuasion go further till yourself come in and use your pleasure. Now the dogs which are to be made for this pleasure should be the most principall, best, and lustiest Spannyels you can get, both of good scent and good courage, yet young, and as little as may be made acquainted with hunting." The late Rawdon B. Lee, a much better authority than Stonehenge, writing about the origin of the setter, states: "However, other 
writers, and perhaps more reliable ones, including Delabere Blane ( 1840 ), say that Robert, Duke of Northumberland, as early as I 555 , is said to have trained a setter to the net; and that other authorities of antecedent dates notice the sitter, or setter, as a dog used for sporting purposes."

Stonehenge, referring to the foregoing, states: "Soon afterward the Setter was produced, either by selection, or by crossing the Talbot Hound with the Spaniel." The inconsistency of Stonehenge-that is, asserting in one relation that the setter is of spaniel origin, and in another relation that its origin may be in a cross of hound and spaniel-is apparent.

Lee quotes quite extensively from Dr. Johannes Caius, a Doctor of Physic of the University of Cambridge, who wrote about the year I570, the following being directly to the point: "The dog called the Setter, in Latin Index.-Another sort of dog there be serviceable for fowling, making no noise with foot or tongue whilst they follow the game. These attend diligently upon their masters, and frame their conditions to such becks, motions and gestures as it shall please him to exhibit and make, either going forward, drawing backward, inclining right hand or yielding to the left. In making mention of fowl, my meaning here is of partridge and quail. When he hath found the bird he keepeth sure and fast silence, and stayeth his steps and will proceed no further, and with close, covert, watching eye, layeth his belly to the ground and so creepeth forward like a worm. When he approach- 
eth near to the place where the bird is, he lays down and with a mark of his paws betrayeth the place of the bird's last abode, whereby it is supposed that this kind of dog is called Index-setter, being, indeed, a name both consonant and agreeable with his quality."

Numerous other ancient writers refer to the setting dog as a land spaniel, but it appears that the term spaniel was generic in its application, being applied indiscriminately to several distinct breeds, thereby hopelessly beclouding the subject. The term, as used at the present day, frequently may have a distinctly different meaning from that of the same term as used centuries ago, and confusion and inaccuracy are sure to arise in any discussion which does not take cognizance of that fact. On this point, the following, taken from "The Gentleman's Recreation" ( 1697 ), is specially pertinent: "The dog which you select for setting must have a perfect and good scent, and be naturally addicted to the hunting of feathers; and the dog may be either Land Spaniel, Water Spaniel, or mongrel of them both; either the Shallow-flewed Hound, Tumbrel, Lurcher, or small bastard mastiff."

To the "Field Book," a sportsman's encyclopedia, published in London in I833, is ascribed the following definition: "The English setter (Canis index, Variety $B$ ) is a breed between the Spanish pointer and the large water spaniel, and was famous for his steadiness and exquisite sense of smelling. The hair on his body was much more curled than the present breed, which has been lengthened by the additional cross of the springer. 
He was also much more steady than the improved variety, but then he has not the same speed to recommend him. ... He has an elegant figure, and is of a very pleasing diversity of color; added to this, his skin is covered with a coat of beautifully curled hair, very rilious on the lower margin of the tail, being altogether an extremely handsome dog, and quite unrivaled by any of the canine species."

These views, in a way, are a summation of the evidence bearing on the setter's origin. For him whose fancy or prejudgments favor a spaniel origin there is much evidence to humor them. In like manner, there is evidence to console him who prefers a spaniel and pointer origin. For him who can impartially consider the pertinent facts, there also is ample evidence that we do not know the origin of the setter. It is lost in the mists of the ages. What are considered as finalities, at best are merely shrewd speculations concerning it.

While recognizing that the act of pointing, in a more or less rudimentary form, is exhibited by spaniels and several other breeds of dogs, and, indeed, by cur dogs, under certain circumstances, it is never like the intensity and efficiency of that displayed by setters and pointers. As a matter of speculation, it is much more plausible that the spaniel was crossed on the old Spanish pointer, which was introduced into England centuries ago, and that the cross-bred product might have been the setter. Here was the pointing instinct ready to hand to breed into the spaniel, an exceedingly simple matter as compared to the far-fetched theory 


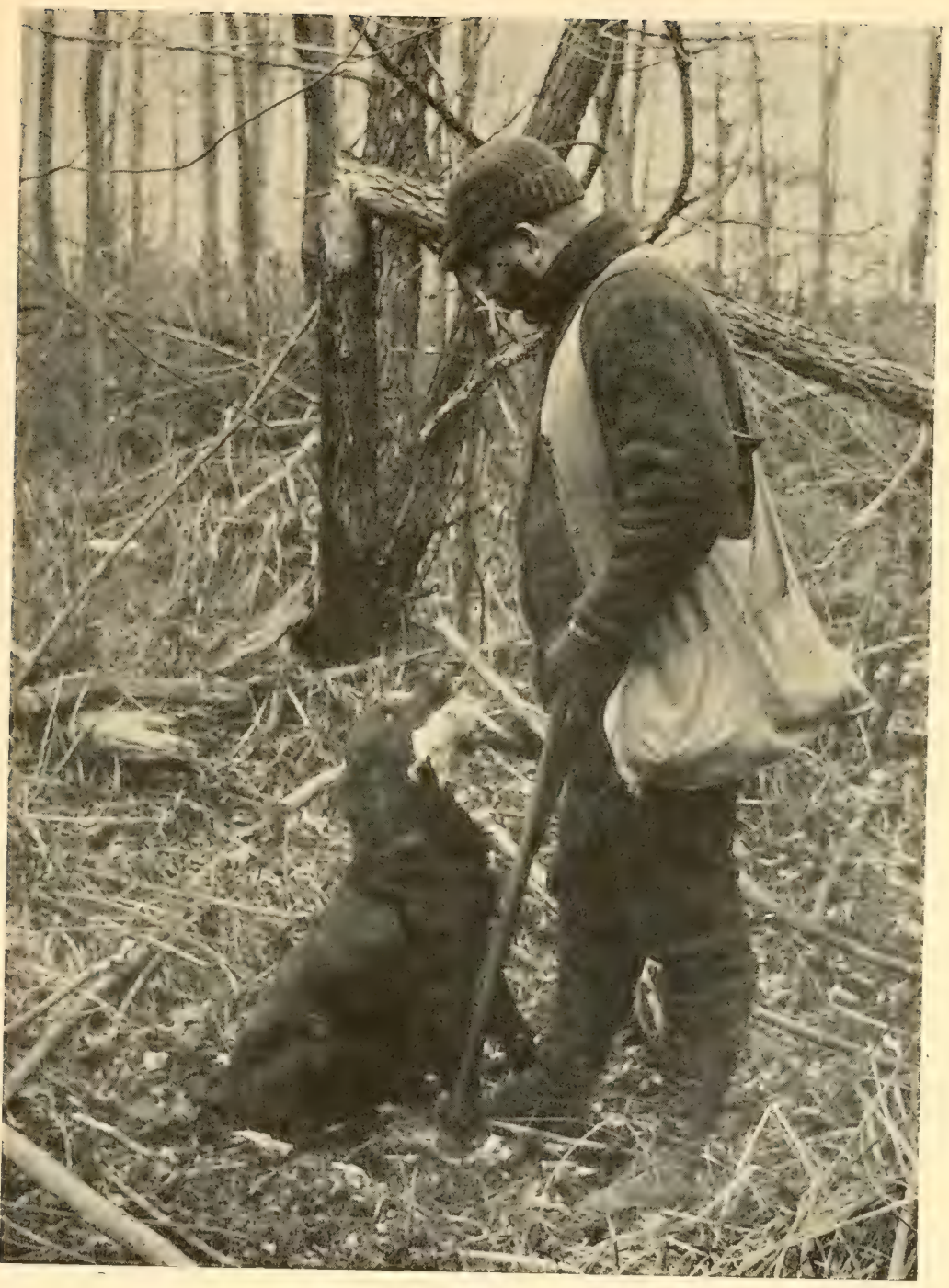

Delivering bird to hand. 

that it was implanted by education. This is sustaine? by the admitted fact that while the setter has infinitely more pointing instinct than has the spaniel, he in turn has much less than has the pointer. It may be objected that the setter does not show any physical resemblance to the pointer. As a matter of fact, he shows a great deal, the chief distinction being in the coat. A cross of setter and pointer-the droppermay appear to be pure setter or pointer. By selection, the physical attributes of the pointer could soon be bred out, while the instinct to point would be added to the many others which the two breeds, spaniel and pointer, possessed in common.

As before remarked, the act of pointing is not the exclusive attribute of pointers and setters. The point seems to be a necessary factor in the successful pursuit of birds, and is many times developed by the dog from observation, from a realization of its helpfulness in effecting a capture. That a dog will change his methods of pursuit to meet its conditions is well shown by the differences of method employed in following the trail of a rabbit and that of birds. In the one case he gives tongue vociferously, in the other he is cautious and silent. While the point no doubt has its origin in an instinctive impulse, as, indeed, the impulse to hunt is instinctive, a high degree of intelligence in its practical application is an essential of its usefulness to man.

The modern setter, as owned by the majority of sportsmen in the United States, is the Llewellin 
setter, a term which denotes merely a certain line of breeding, of mixed English and Gordon setter blood. This family of setters originated in the ' 6 os of the last century, and was a product of Barclay Field's Duke and Thomas Statter's Rhœbe, or either of them or their progeny crossed on any Laverack setter. The Duke-Rhœles had a large percentage of Gordon setter blood, and so were cross-bred. However, the cross produced some grand working dogs and field-trial winners. So great was the success of the Duke-Rhœbes and Duke-Rhœbe-Laveracks in field work and field-trial competition, that the superiority of this family was generally conceded. It was known for a time as "The Field Trial Setter," and was so known when the first importations to this country took place, in I874. Although there are many good native setters, so called, in this country, the Llewellin is far away the most popular with sportsmen. After Mr. Llewellin took up the field-trial setter, and bred it for a short time, it was called the Llewellin setter.

The Laverack setter was a strain of dogs bred by the late Edward Laverack, who averred that they were descended exclusively from Ponto and Old Moll, purchased by him of Rev. A. Harrison in I825, and supposed to have been bred pure during thirty-five years prior to that time. However, the Laverack pedigrees have been subjected to much hostile criticism. There is much good evidence which shows that Laverack introduced outside crosses into his kennel, and the pedigree table, published in his work, "The Setter," con- 
tains internal evidence tending to show that it is spurious; that is to say, there are only four and five generations given to cover a period of about forty years, showing that much of the breeding was done when the dogs and bitches were old, and ordinarily, in many instances, past the years of reproduction. Nevertheless, the Laverack setter, when at his best, was beautiful in physique and a grand worker.

The pure Laverack setter, in the years near the end of Laverack's life, became very delicate and difficult to rear. The mortality was extremely high. At the time of Mr. Laverack's death-he died in 1877 - he had nearly lost the breed. There probably is not a pure Laverack setter in existence to-day, but its blood predominates in the Llewellin setter.

The colors of the English setter are orange and white, liver and white, black and white with tan markings, roan, lemon and white, black and white ticked with large black splashes, known as blue Belton-a designation first employed by Laverack, naming it after a village in Northumberland County, England-and solid colors, liver, black, white, orange. lemon, though, as solid colors are difficult to distinguish when the dog is working afield, parti-colors are more desirable. Dogs should weigh from forty-five to sixty-five pounds, and bitches a few pounds less. A dog, when too light in weight, finds great difficulty in heavy going, whether mud or dense vegetation.

The origin of the Irish setter is unknown. He undoubtedly originated very far back in the past. While 
the Irish setter color, to conform to the standard, should be a deep red, or, as the Irish Setter Club of England has it, "a rich golden chestnut," in ancient times the color was red and white, and the red then was not so deep and rich in color. The insistence on color is a bench show qualification. However, a trifle of white on toes, forehead, chest or face is not a disqualification. In English field trials and field work the Irish setter has succeeded far better than he has in the same line of effort in this country, though this applies to his status of some years ago. The Irish setter is but little used by American sportsmen, and in field-trial competition is rarely seen.

The latter-day Irish setter seems to be lacking in speed, range, endurance and general capabilities, as compared with his more popular congeners, the pointer and English setter. Physically, like the English setter, which, in the main, he resembles closely, he is the embodiment of grace and beauty.

Many things point to the conclusion that the black and tan, or Gordon setter, is of comparatively recent origin. Ancient writers are silent concerning him, which would indicate that he was unknown to them. No one knows where the Duke of Gordon obtained his dogs. It is supposed that this breed is a composite of setter, collie and bloodhound, the latter showing strongly in the generous dewlap, the coarser skeleton, the larger, heavier head, the haw, and the tendency, when at work, to use on the trail the methods of a hound rather than those of the setter. The collie cross 
is shown by the tail and its carriage, and by the tendency to head off birds in manner similar to that employed in herding sheep. In color the Gordon setter is supposed to be deep black and tan, though there is good proof that the dogs at Gordon Castle were black and tan, black, tan and white, and liver and white. Laverack, in "The Setter," wrote of them as follows: "As far as my observation goes, they lack the endurance of the other breeds that I have named; they are coarser and heavier made, and have not the light and agile action of the blacks, the black and whites, the black-grays, or blue and lemon and white Beltons I have tested. . . Black-tans, as a rule, have sour, coarse heads; shoulders loaded, heavy, and too upright; are heavy and thick-limbed; large feet, often too straight and tilty in the hind quarters; tail thick and ropy. Many of the black-tans have obstinate, stubborn tempers, and are not particularly easy to break."

The modern pointer is supposed to he a descendant of the old Spanish pointer which was introduced into England in the early part of the eighteenth century. The Spanish pointer was a coarse, slow dog, sadly inefficient in the matter of speed and range, to improve which a foxhound cross was introduced. The much racier modern type is said to be the result. In the late '7os and early 'Sos of the last century many pointersdogs and bitches-of excellent blood, and fame as workers, were imported from England; but, strange to relate, only an exceedingly small percentage of their offspring proved to be noteworthy as workers afield, 
and quite as small a percentage of these imported dogs and bitches showed the excellent field form with which they were credited abroad. Many of them were first class in bench show competition, but as a whole they were lamentably inferior as workers. However, during the past two decades there has been wonderful improvement in this breed, quite a number of pointers showing ability equal to that of the best setters in field work and field-trial competition.

The comparative qualities of setter and pointer have been long debated without any final conclusions being reached. It is held that the pointer, having much the shorter coat as a rule, suffers much less from excessive heat than does his longer-haired brother; but that dictum has so many exceptions that it is far from being accepted. The shorter coat of the pointer, in comparison with that of the setter, counts for very little; for the setter, when properly conditioned by actual field work, loses nearly all his feather, and his coat, also, is much thinned and shortened from contact with the cover. Unless fully conditioned and acclimated, both suffer much distress in hot weather, and then, if set at work, soon become exhausted. It is claimed for the pointer that he can do without water better than the setter. I myself have shot over both breeds extensively when the weather was hot, and where water was scarce, and I never observed this difference. As a rule, both breeds require an abundance of water in hot weather. Occasionally, one-either pointer or setter, as the case may be-will show phenomenal en- 
durance without the usual supply of water, but this is the rare exception, and furnishes no data on which to formulate any rule applicable to either breed.

It is claimed as a point of superiority for the setter, that his longer, protecting coat enables him to take punishing cover much better than the pointer can. The claim is fallacious. Many setters are quite intent on saving their precious skins when working where there is brush or bramble; on the other hand, many pointers will face punishing cover without flinching. This phase of work is dependent on the dog's individual courage and his love of hunting, naturally possessed, much more than upon the physical attribute of coat. Some dogs can go through cover without much suffering, while others are punished severely. Some dogs are continually suffering injuries under any conditions. It all resolves itself into whether the dog tries to save his skin, or is so stupid and awkward that he cannot do so.

As to the general traits of the two breeds, the pointer is much the greater glutton on opportunity, is much more likely to go stale, and so remain indefinitely, from overwork, and to lose his dash and industry in middle life. As a breed, the pointer does not display the fire, endurance and sharp quickness in his bird work that the setter does, and so is greatly handicapped in fieldtrial competition. However, he takes to pointing much earlier in life, and more naturally, than the setter, and therefore is much easier to train, and retains his training much better. 
Nevertheless, the pointing instinct, if exercised beyond useful limitations, may be a serious impairment of a rlog's usefulness, as, while it fundamentally is an instinct, its usefulness to man depends entirely on its intelligent application in meeting special requirements.

The pointing instinct of the pointer and setter, combined with their propensity to hunt birds diligently, establishes their chief claim to excellence in upland shooting. We do not know whence the pointing instinct was derived. Even if we concede that it was a natural evolution from education to dropping for the convenience of the net, this in no wise accounts for its origin in the old Spanish pointer. It is more reasonable to assume that the instinct to point is present in all breeds of dogs which will hunt birds. Of course, it differs much in degree of intensity and manner of application in breeds other than pointers and setters, but it is there, nevertheless. Cur dogs which have been used for all round pot-hunting purposes, acquiring thereby a knowledge of the best methods in the pursuit of birds, oftentimes learn to trail the latter and make use of the point when the birds are located. As a matter of course, they are far inferior to setters and pointers in every respect, in upland shooting, but that is aside from the matter under consideration. When roading birds the cur dog observes the stealthy, mute methods of the setter and pointer, although when in pursuit of fur he may give tongue frantically, as may also the setter and pointer. This seems to indicate that it is an instinct common to all dogs, and exhibited 
with more or less intensity under certain conditions, as already mentioned.

The exigencies of the pursuit of different animals determines in the main the choice of methods. It is quite obvious that a noisy, impetuous method, which might be successful in the pursuit of an animal that trusts for escape to its wits and legs, would wholly fail if employed in the pursuit of an animal which can fly swiftly away. If we assume that the point is an intelligent act, useful to the dog in securing a food supply, there then is no more difficulty in accounting for it than there is in accounting for any other phenomena of canine life. Foxes and wolves draw on their prey and make the point, which is merely the pause to accurately locate the exact position of the prey, preparatory to the final spring to capture. The feathering and bristling of the hair on the back are not exclusive traits of bird dogs. All dogs, on the eve of a bloody attack, exhibit it. Every one at all familiar with the habits of dogs has seen even cur dogs, strangely met, draw toward each other with hair bristling, stopping betimes in the attitucle of a point, all concluding with a final rush which may end in battle or friendship, accordingly as the principals are fighters or bluffers. Cats, in stalking their prey, exhibit many of the characteristics of drawing and pointing. Whoever has seen a setter or pointer make a mighty spring after pausing a mornent-that is, pointing-in an effort to capture birds, has noted the amazing swiftness of the act, and that to make such a supreme effort the dog 
must set himself at the start, so that all his muscle: would co-ordinate to accomplish it. This pause, so useful in the dog's natural efforts to secure a food supply, serves a double purpose in such attempt: it enables him to locate the birds accurately before making the final spring to capture, and it enables him to spring powerfully and accurately. Sometimes, withal, the dog makes a false estimate, and springs wide of the mark, thus totally failing in his attempt.

The point, however, does not always indicate the presence of game. Under such conditions the act is called a false point, and it may be a rarity in the field work of a dog, or it may be of frequent occurrence, or may happen irregularly. A dog which habitually false points is next to worthless for field work. The fault is displayed by some dogs under unfavorable weather conditions, which affect the scent. The majority of dogs will false point when fagged out or when stale from overwork, day after day. There is no cure for habitual false pointing. It probably is the result of a faulty brain or nose, or both combined, or, it may be, of overcaution.

The standard of field work is precisely alike for pointers and setters. In their methods of work, natural or acquired, there are no particular differences which can properly be classed as peculiar exclusively to either breed. Yet each pointer or setter, in performing identical tasks, may have his own individual methods and mannerisms, no two dogs working or planning alike, just as no two men think or act pre- 
cisely alike. Thus, while the main essentials of field work, such as ranging, judgment, pointing, roading, etc., are constants, there may be an infinity of variable detail in accomplishing like results.

For the better comprehension of the terminology of upland shooting, some explanations will be of value.

The terms pointing, standing, and setting, denote the pause, generally very tense and spirited, which the pointer or setter makes when either has located birds definitely, or which, when trailing them, he makes in an attempt to locate their direction or whereabouts. The dog, when pointing, may be quite close to the birds or a long distance from them, variable circumstances entering into the consideration of this matter, such as whether the wind brings the scent directly from the birds to the dog's nose; whether the dog's nose is keen enough to locate the birds without pressing in close to them; whether at the time the birds are in thick or thin cover, or no cover at all; or whether it is at a season when they are either reluctant to take wing, or will flush instantly at the slightest alarm. All these different circumstances the wise, capable, experienced field dog recognizes and observes.

The functional powers of the dogs' noses, in respect to pointing, vary greatly in the matter of efficiency. There is nothing remarkable in this if we consider that there is much variability in sense organs-as in the eyesight of man.

Supplementary to a dog's efficiency in locating and pointing birds are his intelligence, as shown by the 
judgment he displays in conducting his efforts and his honesty of purpose and cheerful effort in working to the gun; these qualities, in sporting parlance, being known by the comprehensive term "bird sense."

But a dog which has a knowledge of approved methods in work to the gun, and skill in combining them successfully according to ever varying circumstances, combined with endurance, cheerfulness and loyalty, is a rarity indeed. He is the genius of his kind. Nevertheless, however excellent a dog may be naturally, unless he has an affection, or at least a tolerance, for the shooter, he will not perform at his best, even if he will perform at all.

So much for the trained dog. Left to his own unhampered will, the natural proclivity of the untrained dog is to impetuously follow his own impulses when in pursuit. At first he trusts to his speed alone. After a certain amount of experience he begins to use his intelligence. When hunting for himself he displays great enthusiasm and industry. This natural method, called self-hunting, is not in accord with the best interests of the gun.

The true theory of training is to preserve the dog's best natural methods, enforcing only such restraint as the needs of the shooter require. No trainer can force a dog to hunt if the latter is disinclined to do so.

The dog's natural inclination, after locating the birds, is to spring in to capture, but this being against the interests of the shooter, the dog is trained to check his impulse to spring while still encouraged to main- 
tain the point. This is not always an easy task to accomplish. While the act of pointing is commonly considered as a marvelous exhibition of the dog's scenting powers, it really is not any more so than is any other organic function.

Drawing and roading are terms used to denote the manner in which a dog approaches the birds by means of their scent.

Drawing has reference to the approach by the body scent. The dog; when drawing, carries his nose well up above the ground, and, if he performs in the best manner, goes to the birds with quickness and precision.

The dog which follows the birds by roading may do so with reasonable quickness and accuracy, or with such awkwardness, slowness and inefficiency that he is next to worthless.

In respect to locating the birds, all that the trainer can do to assist is to afford the dog proper opportunities for practice. Each dog selects his own methods, and arbitrary methods cannot be forced on him.

There is a vast difference in the functional powers of dogs' noses and intelligence, therefore all dogs cannot work up to the same standard.

Drawing is far away the best method of locating birds, although in certain conditions of weather, when the scent lies low, the dog which carries a high nose on the trail encounters a difficult problem. But, under favorable conditions, when he strikes a trail he may follow it at top speed and locate the birds with marvelous quickness and sharpness. Such a performer 
would have the birds located before the dog which picks his way painfully and slowly along by the foot scent had well begun. The advantage of drawing as compared to roading is thus apparent, and it is of special advantage in field trial competition.

Some dogs have the ability to draw or road, adapting their efforts to the scenting conditions, and acquitting themselves creditably. However, every dog which carries a high nose in the attempt to locate is not necessarily a good performer. There are wide-ranging, high-nosed dogs which are poor finders. The only test by which a dog's merit can be properly determined is his actual work afield.

Ranging is a term which denotes the casts taken by the dog, to and fro, while beating out the ground in the search for birds. It may be done in many quite different but successful ways, or it may be done in a way which at once demonstrates that the dog has no hunting intelligence whatever so far as the needs of the gun are concerned. Inability, due to stupidity, cannot be overcome by training. Neither a foolish man nor a foolish dog should be expected to surpass his natural limitations.

A good nose is an aid of inestimable value in supplementing industry and good judgment. It commands a great area, thus enabling its possessor to search out much more territory with fewer casts than is possible to his fellow with the poorer nose.

The good ranger maintains constant observation of the wind. He skirts promising stretches of cover 
on the leeward side, so that, if there are therein any birds in hiding, he will catch their scent. He recognizes the likely places for birds, and, planning with them in mind, he conducts his range after a well-laid scheme, thereby economizing time and effort. On the other hand, the dog possessing a poor nose is quite likely to range here and there, hither and thither, hit or miss, as it may happen, working the same ground over repeatedly while leaving other places, perhaps the most likely ones for game, unnoticed.

A fast dog, if he uses his nose properly, is the best, provided he can maintain his pace uniformly for a considerable time. It is obvious that such a dog can cover a certain area in a certain time much more thoroughly than a slower worker can.

Many dogs will start at high speed, slowing down gradually thereafter, till they practically quit. A lot of stamina and pluck are required to maintain a fast pace while hunting during several hours in succession. A moderate degree of speed, uniformly sustained, is much to be preferred over high speed of uncertain duration. Some slow dogs, of surpassing cumning in their work, are excellent bird finders. Though a dog may be slow he nevertheless may take wide casts, and if his nose and judgment are good, combined with honest work to the gun, he has the essentials of a hunting dog.

As to methods of hunting out any game area, the dog, if given the opportunity, learns them best when left to his own devices, without interference from 
his trainer. The latter can hamper the dog's progress by interference, but he can do very little to assist. With age and experience, all intelligent dogs improve in their hunting methods.

Many of the best finding dogs are those which have indulged in self-hunting, a term which denotes that the dog hunts independently, as when he sneaks off alone, or in the company of other self-hunting dogs, or as he pleases when with his trainer. Under such conditions he hunts till wearied or till satisfied, which may be in a few hours or a few days, according to the endurance, longing, and the food supply.

Commonly, after a vagrant self-hunting trip, the dog returns mere skin and bone, the exposure, prolonged exertion and short rations producing their natural results. The vagrant, under such circumstances, regains his flesh as quickly as he lost it, if properly fed.

Vagrant excursions should be strictly suppressed. They afford unlimited opportunity for the formation of bad habits, such as harrying sheep, killing fowls, robbing nests, etc. The self-hunting proclivity manifests itself sometimes when working to the gun. The self-hunters will apparently work under control for a longer or shorter time, gradually ignoring the shooter, till at last they go where and when they please. This insubordinate stage lasts according to the whim of the dog. It may be for a brief while, or it may last a day or two. Meanwhile the dog is learning a great deal in respect to ways and means of finding Dirds, though of no service whatever to the gun while so absent. 


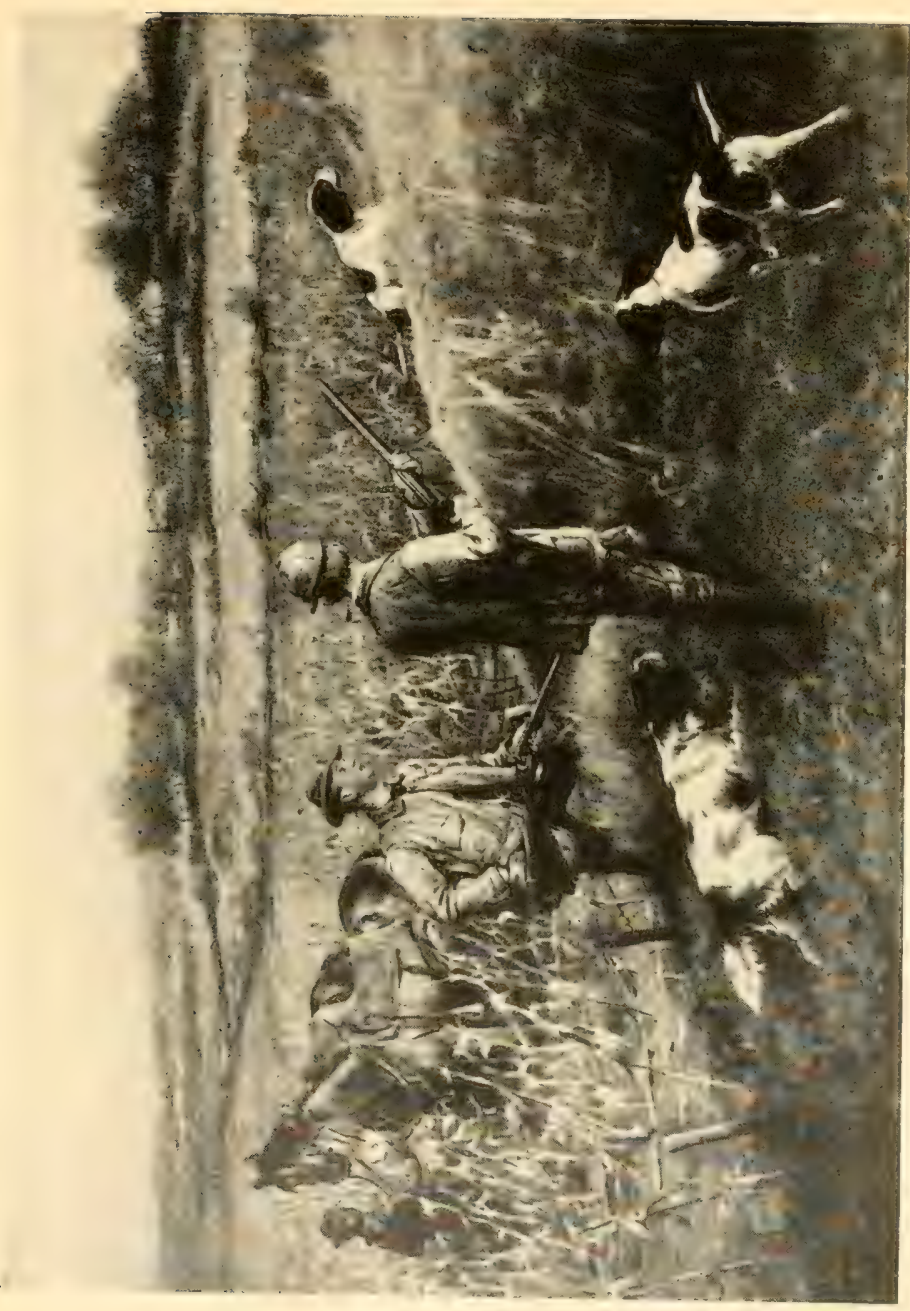

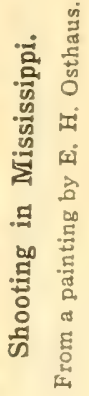



In ranging, the dog should adjust his efforts to fit the circumstances of cover and open, casting closer in a broken cover country than in an open country, and he should come into view of the shooter at reasunable intervals to note the proper course as a base line to guide him in keeping within proper bounds. When hunting in cover exclusively, as in hunting ruffed grouse and woodcock, his proper range should not much exceed that of the spaniel; that is, gunshot.

Back, back stand, or back set, is when one dog stands stanchly at sight of a pointing dog, the attitude of the backing dog being much like that which he assumes on a point, though in many instances it is more or less relaxed. In any case, as the dog advances in years, he backs with less intensity.

If the pointing dog has pointed false a few times, the backing dog, observing that the act is deceptive, loses confidence in his fellow worker, disregards his points, and goes on about his own affairs, or breaks in to see what it is all about.

Dogs quickly comprehend the significance of each other's movements. Some deferential dogs will back when they observe their bracemate drawing on game, being satisfied to take a subordinate position at every opportunity. Other dogs, on the contrary, may cast in ahead at top speed when they see a dog roading or drawing, being ambitious to secure the point. Some will back well for a moment, then move forward a few steps at a time, playing craftily to steal the point. Some dogs, again, will back or point honestly when 
under the eye of the shooter; out of sight, they are lawless. Again, some dogs which point well refuse to back at all.

So far as work to the gun is concerned, the purpose of the back, apart from its spectacular features, is to guard against interference with the pointing dog. If a dog refuses to back he can be taught to drop instantly to oral command or to signal or to his bracemate's point. This detracts from the spectacular beauties of shooting, but a good dog should not be condemned because of failure in this respect.

Quartering denotes a system of beating out the ground in substantially parallel casts at right angles to the course of the shooter. This method has never been esteemed in this country, although it was viewed with favor in some sections of England. It fitted in usefully in English shooting, as on the English preserves the birds, in many fields, were quite as likely to be in one place as another; therefore, it was an essential that every bit of ground be searched out thoroughly. In this country, there being much unpromising area in ratio to likely area, the really serviceable dog uses his brains in hunting only in the likely places. These conditions are ever changing. The local conditions must always be the guide of action; no arbitrary rule is possible.

Before attempting to shoot game over a dog's points with a serious purpose to secure enjoyable sport, it is better to give him a thorough schooling in the different commands, and their significance, and therewith 
sufficient discipline in obeying them, so that, when afield, there will not be too many conflicting ideas in his head. Added to all this, the dog should have sufficient experience in working on birds and working to the gun, so that there will be sport instead of chaos.

Beyond a perfunctory feeding of his dog, the average dog owner, in times past, gave little thought to the animal's general well-being. If given an abundance of food, without any consideration as to whether it met the dog's bodily needs, he was considered to have received all the attention necessary. In recent years, however, there has been a better understanding of the need of promoting the comfort and general welfare of the dog, and to this understanding bench shows and field trials have contributed incalculable missionary work. Much valuable literature has become available on all subjects of canine interest, and so a better general knowledge of the dog's requirements.

There are various kinds of excellent proprietary dog foods on the market, so cheap as to price, though excellent as to quality, that they are within the reach of the most slender purse. Table scraps, assuming that they are other than potato skins and bare bones, make a good dog food. Milk, sweet, sour, or buttermilk, may be given to the dog in abundance. The latter is a specially good summer drink for the dog, as it also is for man. Contrary to a popular belief, milk does not generate worms.

If an owner does not care to purchase proprietary foods, and the table scraps are insufficient for the needs 
of his kennel, scraps of mutton, beef, or goat meat, stewed with cabbage, onions, beets, turnips, and other vegetables-observing that all are strictly sound and good-make an excellent food during the idle months. When a dog is used for field work the food should be almost wholly meat. Sheep's heads and tripe make an excellent food, preferably in a stew. The former should be skinned, and boiled till the bones can be readily removed from the flesh. Corn meal, though quite commonly used, is one of the poorest of dog foods, much of it being undigested, as can readily be known by an examination of the dog's droppings.

For working dogs, one feed after the day's work is ended is quite sufficient. They then should have all that they will eat. If fed in the morning, digestion is suspended while the dog is ranging about, and he is carrying with him the equivalent of so much dead weight, with no nutritive qualities for the time being.

If fed on a meat diet when working, the dog is almost exempt from bowel troubles, while if fed much corn meal such troubles are frequent. For the latter there is no better or prompter remedy than lean beef, cut into small pieces, and heated through in a hot oven, thus being only blood rare.

If a dog's stomach is loaded when he is at work his powers of scent are seriously impaired. It matters not whether he is fed on meat or vegetables. Nature has wisely provided that while digestion is in progress the dog's sense of smell is dulled. Even man, whose sense of smell is incomparably inferior to that of the dog, 
can smell a dinner a long way off when he is hungry; whereas, after dinner, the same gratifying fragrance is unrecognized.

Man's own requirements are no data on which to judge of the food needs of the dog. The latter, being carnivorous, requires food far less frequently than man, while the latter, in turn, feerls less frequently than the ox, which is wholly herbivorous.

Next to a good food supply, the dog needs a comfortable, well-ventilated, sanitary place in which to sleep. Any man who cannot afford such a place, and neglects his dog's comfort in this respect, cannot afford to own a dog, consistently with humane requirements. With this, the dog should have plenty of exercise. It is best that he should have entire freedom, but as this is not always possible, particularly within city limits, regular times each day should be allotted for that purpose. 

PART III

\section{THE SHOOTING OF THE FUTURE}





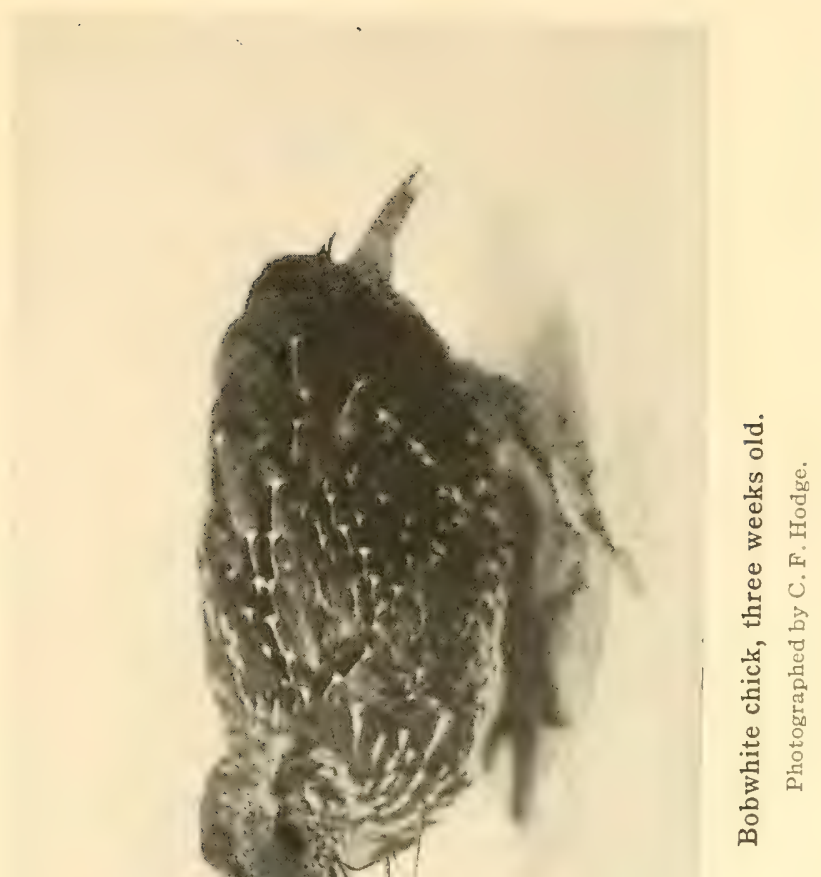





\section{THE SHOOTING OF THE FUTURE}

\section{A LOOK BACKWARD}

When the white men came to America they found wild birds and animals very abundant. The reproductive energy of indigenous species more than made up for their destruction by natural enemies. Human beings were not numerous in proportion to the area of the land, and took only what they needed. The balance of nature was preserved.

It was rudely disturbed by the arrival of civilized man with his firearms, though for a time he made little impression on the life of the great continent to which he had come. Birds and animals continued abundant, though close to the settlements they were soon driven away or destroyed. Thus Josselyn, writing in $167 \mathrm{I}$. tells, as already said, how thirty years before turkeys were very abundant at Black Point, now Scarborough, Maine, where many broods of young might be seen in a morning, but that the English and the Indians have destroyed them, "so that "tis very rare to meet with a wild Turkie in the Woods." This was only about fifty years after the landing of the Pilgrim Fathers. 
In the early days of the settlements game was killed for food, and not for sport. The arm carrying the single ball comes first into a new country, and the shotgun follows at some distance of time. The musket or rifle is a necessity; the shotgun a luxury. The rifle protects life and property, supplies food for the family, destroys the wild beasts that would prey upon the settler's stock. The shotgun is used in hours of leisure and recreation. Food captured by its aid is a delicacy. It is the implement of sport. In the settlement of America this has been everywhere the case.

The hardy pioneer disdained to kill his game with more than a single ball, which it was his pride to plant wherever he chose, and in his expert hands the old crooked-stock pea-rifle was his dependence for support, as it was the terror of the savage tribes into whose territory he pushed his fearless way. Many, many years later, when the land had been cleared and waving fields of corn and wheat had taken the place of the wild grasses that once grew rank and thick along the valleys and over the prairie, when the large game had almost entirely disappeared, the children or the grandchildren of the rifleman began to use the shotgun. Geese and ducks, the noisy grouse, the brown quail, the whistling woodcock and the twisting snipe became the objects of pursuit to those whose fathers had killed the elk, the moose and the buffalo. The fathers hunted for meat. With them it was a fight for life. Each ball and each charge of powder was to be accounted for and must do its work. The sons and grandsons inherited the hunt- 
ing spirit from their sires, but no pressing need drove them to the field. They shot-for pleasure-wild fowl and game birds when these were to be had, but if not these, too often they destroyed in their ignorance tiny songbirds which were their best friends.

Many a man has seen with his own eyes the expulsion of the rifle by the shotgun from more than one section of the land. Little more than a generation ago the shotgun was scarcely known in central Nebraska. Then it was necessary on occasion to fight off Sioux or Cheyennes or Arapahoes, while the buffalo, elk, deer and antelope were needed for food. The years have rolled by; the riffle has disappeared. Either it went westward to the mountains with its owner, or, rusty and dirty, it stands to-day neglected in a corner of the garret. All the young men and boys have shotguns, and in the season the geese that visit the river bottoms, the ducks of the sloughs, the prairie chickens on the upland and the quail in the tow-heads are constantly pursued.

So, in the settling up of a country the weapon adapts itself to the game to be killed. As long as large mammals are abundant the rifle holds its own, but when these are gone it must give place to the weapon of shorter range.

It was not until toward the middle of the nineteenth century that the birds of the United States began to be shot for sport. Before this the markets offered inducements to the thoughtless or the greedy to destroy birds with great recklessness. Game birds were taken in nets, 
snares and traps in vast numbers, and as early as 1855 and ' 56 a writer said: "The havoc and slaughter, not only by the mercenary and cruel, but by the thoughtless and improvident, have consequently been very great, both of birds and animals, thousands of buffaloes, deer and hares, hundreds of wolves, panthers and bears, as well as myriads of partridges and hecatombs of grouse, have been slain and trapped. The markets of all our principal cities have been most bountifully supplied with every description of game-in fact, filled to repletion with partridges and grouse; not, however, as many suppose, with birds alone coming from the far, far West, but by incredible numbers of half-starved victims snared in our own and the neighboring States or mercilessly shot down, whole coveys at a 'blow,' as they sit huddled together on the treacherous snow, stupefied and benumbed with the chilling blasts of the north."

Some of the sportsmen of that day were Englishmen, and of these Wm. Henry Herbert-Frank Foresterwas one of the most famous. Herbert wrote in charming style, and professed high ideals of sport. His writings were read by all who were fond of shooting and fishing, and exercised a good influence. Birds at that time were so extremely abundant-from the point of view of to-day - that no one realized the importance of moderation in killing, and the bags made were very large. Herbert inculcated good views of sport, and his teachings were far in advance of the practice of his day. Nevertheless, it was then a point of pride, as indeed it still was at a very recent day, to do a little better-that 
is, to kill a few more birds-than your neighbor or your rival.

Although all the larger game birds had been exterminated in the Eastern and Middle States by the time of the Civil War, it was not until the advent of the breech-loader in America, about I 868 or '69, that bird shooting began to be excessive in nearby localities. Yet, hy the middle of the following decade, complaints began to be heard of the scarcity of game. People who a few years before had had no difficulty in killing thirty birds in a day, grumbled when they could get but fifteen, or perhaps ten, and found vacant covers long known to be depended on for a certain number of birds. These were the first warnings of the scarcity of game birds, which, since that time, we all have known.

In those days, too, the gunners interested themselves much in the question as to which was the most useful arm, the breech-loader or the muzzle-loader. Those who had adopted the new weapon vaunted its convenience and general efficiency, while the more conservative declared that the breech-loader did not throw shot with the force of the muzzle-loader, and declared that they would never change their weapons.

It was about this time that the first periodicals devoted exclusively to shooting and fishing were established. These were, first, the American Sportsman, which lived but two or three years, and then Forest and Strcam, which subsequently absorbed the successor of the American Sportsman, the Rod and Gun. These journals were immediately successful, because of the 
interest felt in their subjects by the sportsmen and field naturalists of that day. Sportsmen had much to say on various topics, and naturalists wished to discuss many matters which could hardly be brought up in publications devoted strictly to science. Many sportsmen were careful and accurate observers, possessed of experience and education, and writing delightfully. Later a large crop of periodicals devoted to these sports sprang up, most of which, before very long, perished for lack of support, their places being taken by others.

These earliest periodicals, being directed by men of foresight and experience, urged upon their readers the importance of preserving the natural resources of the country. They preached game protection and forest protection, and while converting not a few of their readers, at first made little or no impression on the general public. Such educational work goes slowly at first, especially when the teaching tends to limit the recreation and pleasures of the public by urging them to practice self-control.

It was thus many years before any definite results could be seen from these teachings, and in the meantime the works of destruction went on. Perhaps the most radical and most important step ever taken in game protection in this country was in the year I894, when Forest and Stream announced its platform plank, "Forbid the Sale of Game." Meantime a constant, though slow, improvement was taking place in the game laws, and a few sportsmen, by earnest work with 


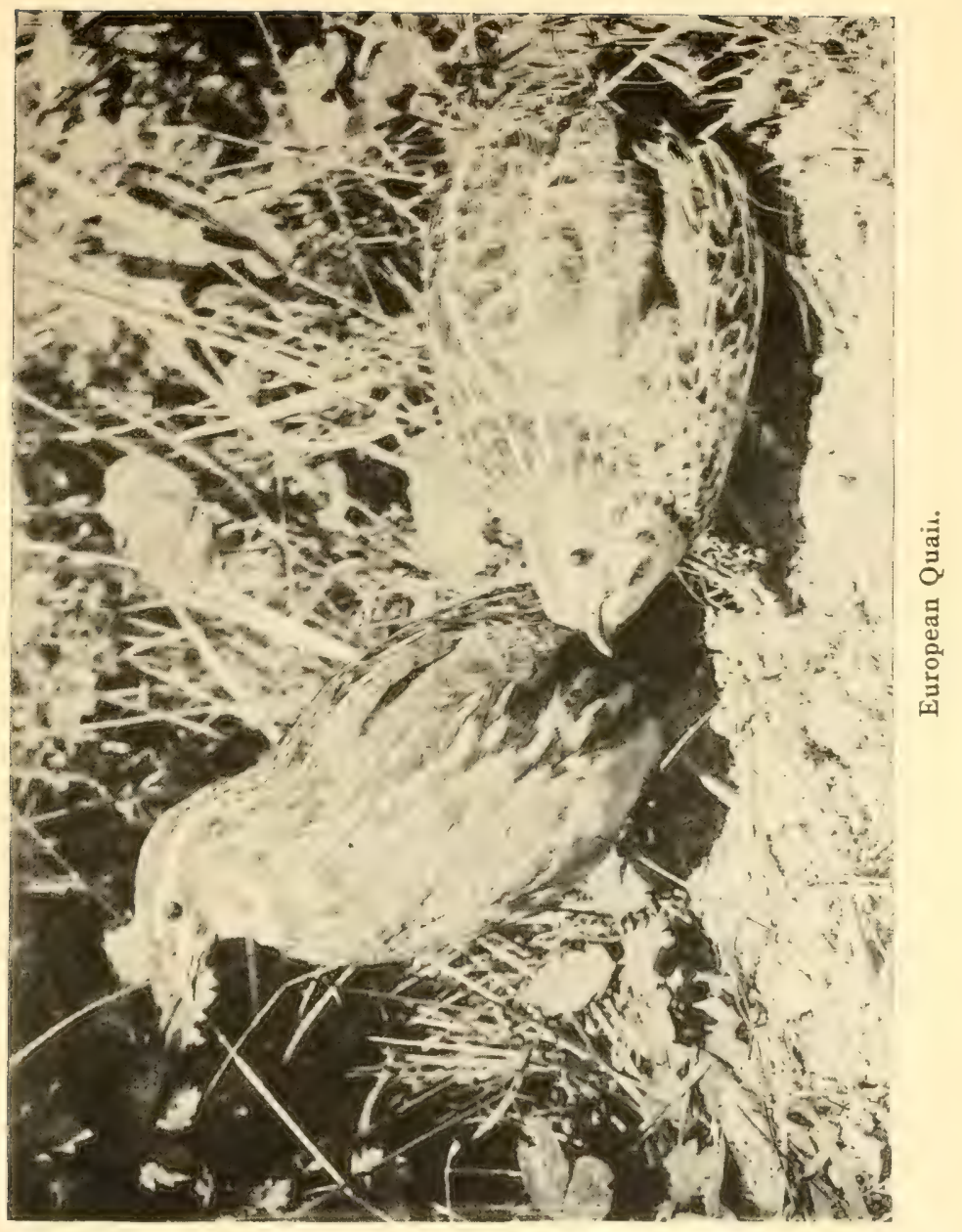



the legislatures, backed up the work which Forest and Stream had set on foot.

Meantime, sportsmen at large discussed with much earnestness the question of what should be done to restock the game covers. The first efforts took the direction of importing bobwhites from the South and turning them loose in covers that had been shot out. This was done, but the birds were soon killed off, for no one seemed to think of stopping shooting. Then came the idea of importing foreign birds, and about 1878 or '79 some one suggested the importation to America of the Old World quail (Cotumix), a migratory bird which breeds in Central and Northern Europe, goes south in autumn, crosses the Mediterranean and spends the winter months in Africa. These birds were easily obtained and were inexpensive. Considerable numbers of them were imported. They appeared to take readily to their new home and many of them bred. Nevertheless, after a time they disappeared without any apparent cause. It was reported that flocks of them had flown out to sea and been drowned, and it is quite possible that, migrating to the shores of the Gulf of Mexico, they attempted to cross that body of water and perished. At all events it is now many years since one of these birds has been authentically reported as taken in America.

Attempts were made to acclimatize the English pheasant in the United States a hundred years ago, but the birds turned loose in New Jersey all disappeared. Another attempt was made early in the nineteenth cen- 
tury, near Belleville, N. J., but again the birds disappeared. It is said that between 1820 and 1830 pheasants were turned out near Baltimore, $\mathrm{Md}$., but by 1830 the last of the birds seems to have vanished.

In I880, Hon. O. N. Denny, then U. S. Consul at Tien-Tsin, China, shipped some ringnecked pheasants to Oregon. Most of these died, but the following year, according to the report of the Fish and Game Protector of Oregon for 1895-96, another shipment was made which did better, and these were set free on the ranch of Mr. John Denny, in the Willamette Valley, in Lynn County, Oregon, where they did well and increased rapidly. In the late winter or early spring, 1885 , an important importation came to Portland. These were again from Consul Denny, and were sent to the people of Oregon in care of a sportsmen's association of Portland. They included several species. Efforts were made to induce the legislature to enact a law protecting them and to make a small appropriation for their care until they could become established. The legislature laughed at these requests and treated them with so much scorn as to create quite a little sympathy for the sportsmen's association, and incidentally for the pheasants. The owner of Protection Island, in Puget Sound, offered to give the birds a home and protect them if desired, and they were turned out there.

In I882 two hundred pairs of English pheasants were brought to New York from England to stock Pierre Lorillard's game preserve in Monmouth County, N. J. They did well there, and with others imported later by 


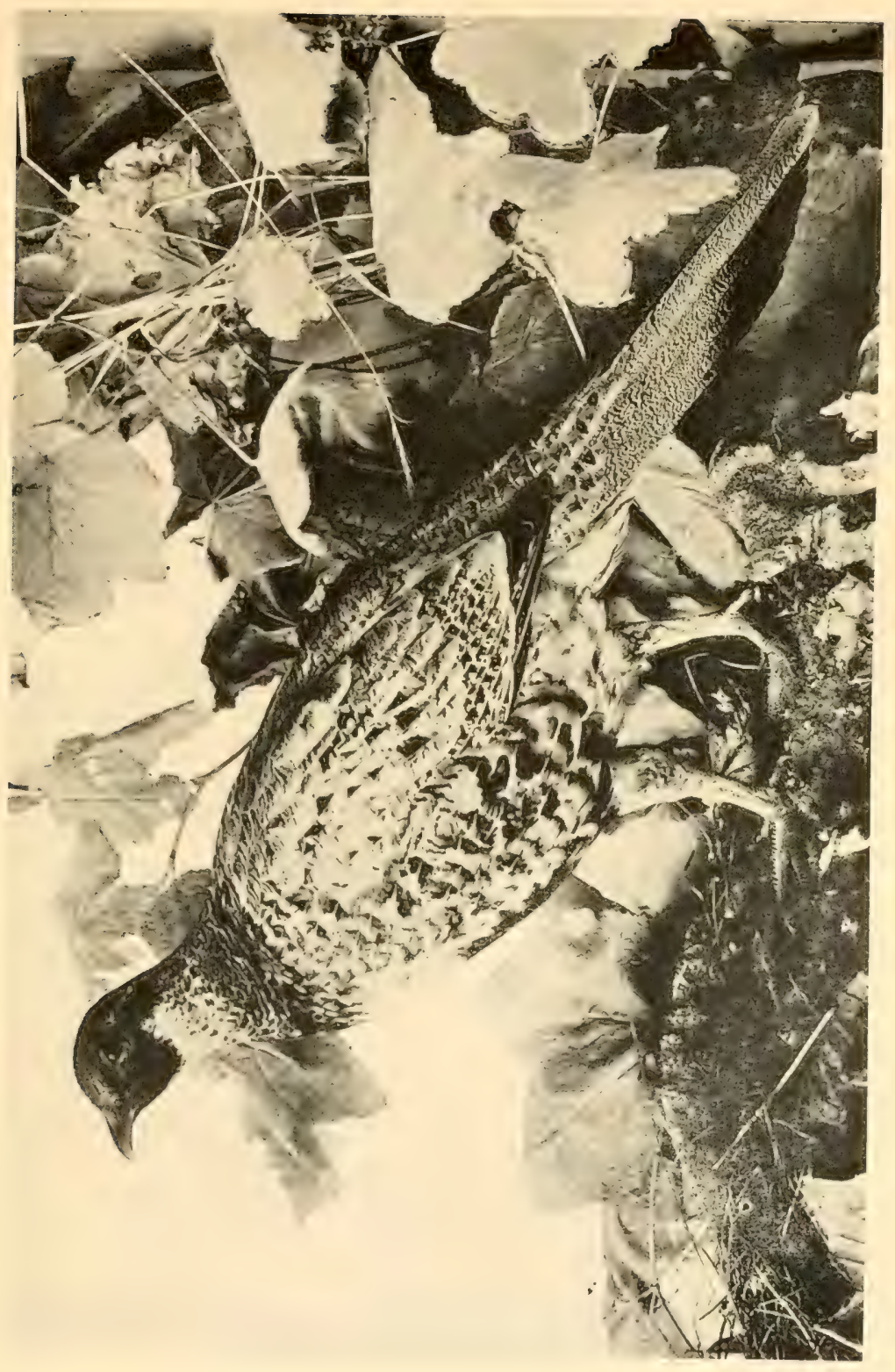

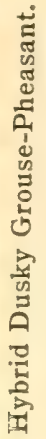



Pierre Lorillard and Rutherford Stuyvesant and turned out at various points in New Jersey and along the border between that State and New York, stocked in a limited way a considerable territory west of the Hudson River.

In the year $188 \mathrm{I}$, nineteen Chinese pheasants were imported to Victoria. Vancouver Island, and set free there, while a law was enacted giving them absolute protection for five years. They increased astonishingly, so that when the closed time was ended there was excellent shooting in the neighborhood of Victoria, and it was estimated that during the first season not less than 3,000 pheasants were killed. During the winter the birds could be seen, sometimes along the roadside and often in the cultivated fields, and were evidently very abundant.

The introduction of the pheasants in Oregon and California was generally welcomed, and public feeling protected the birds. It appeared that the climate was well suited to them. They increased rapidly, and now for many years have been abundant on the coast, but chiefly in the region of great precipitation. They have apparently not spread greatly to the south, into the dry region of California, although in that State there are believed to be some persons breeding pheasants in semiconfinement in a small way.

The birds are popular on the coast. Some fruit-raisers, to be sure, declare that they injure the crops, but on the whole they are regarded as a welcome addition 
to the fauna of the region. In a few instances they have interbred with the dusky grouse.

During the last thirty years a number of different exotic species have been suggested as useful birds for American shooters. Pheasants have done fairly well in certain eastern localities besides those mentioned. Major W. A. Wadsworth introduced them into the Genesee Valley, and Dr. W. Seward Webb has a large preserve in Vermont, where birds are hand-reared and turned out to be shot in battues once or twice a year. The Blooming Grove Park Association in Pennsylvania has successfully raised pheasants, and each year the members are permitted to kill a certain number, while many other parks and associations, to say nothing of some State farms and a multitude of commercial people, have been engaged in the work of rearing these handsome birds. It has been demonstrated that the pheasant will endure the rigorous climate of the north, at least as far as central or northern New York.

The pheasants are not without their opponents. It has been alleged that they destroy or drive off our native game birds; that they injure certain crops; and that while they themselves are immune to certain diseases, they yet may communicate these diseases to our native birds.

The latest candidate for public favor on the roll of foreign game birds is the so-called Hungarian partridge-the gray partridge of Europe. It is a bird nearly as large as the ruffed grouse, and is hardy and offers good shooting. It is only within three or four 


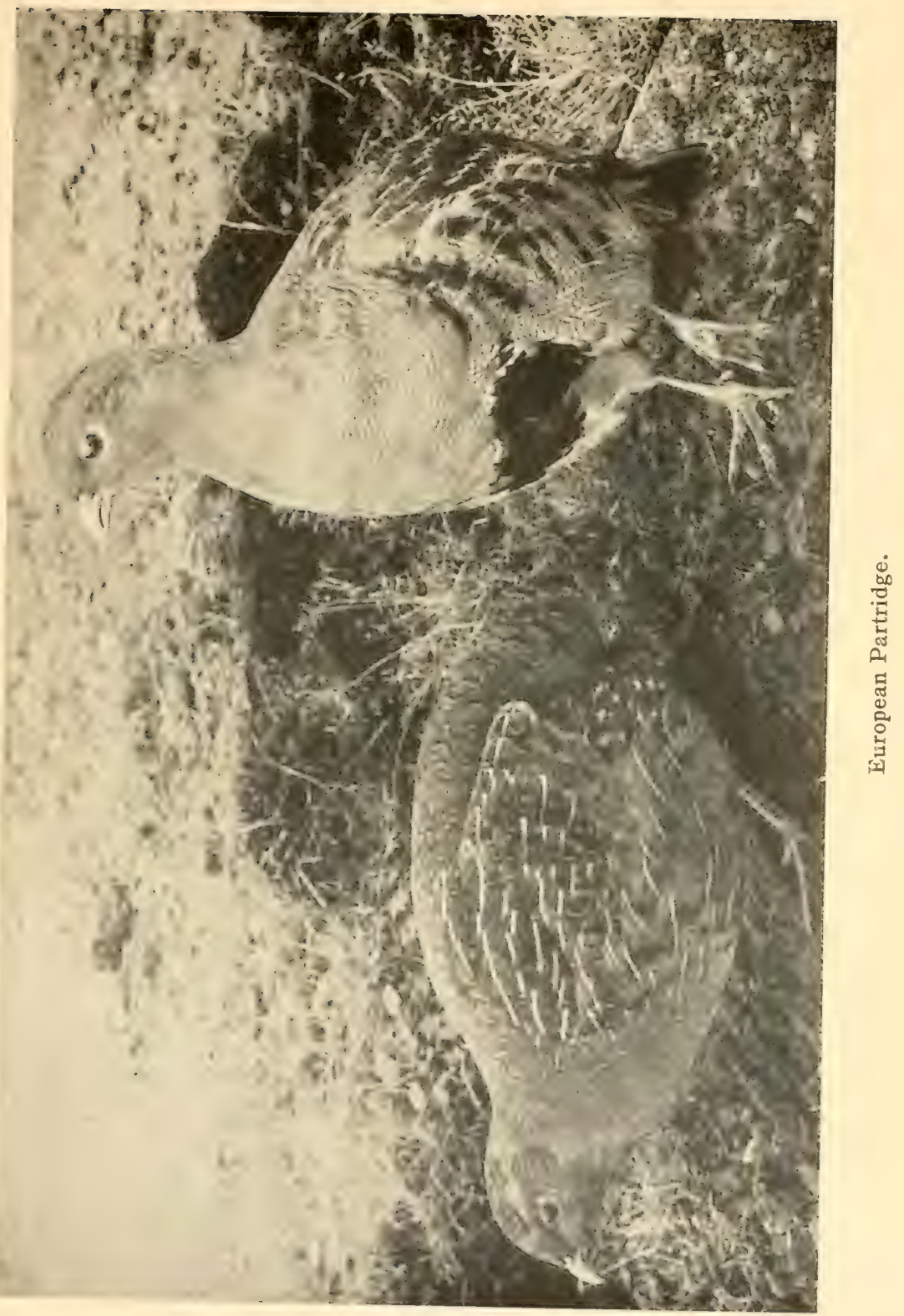



years that it has been imported in considerable numbers, the earliest importations having taken place in 1905 or 'o6. It is reported to have done well, and by many is believed to be the coming game bird.

Besides those named, few foreign game birds have been introduced, and those in small numbers only. Mr. W. W. Thomas many years ago was instrumental in importing and liberating in Maine some capercailzie and black game. Black game was also imported and turned loose on the Island of Newfoundland. So far as known, nothing was ever heard of the birds. Much later, some capercailzie were imported and turned out in Algonquin Park, in Canada, whence for several years reports have come of young broods seen. Some European grouse, including, we believe, ryper, black game and capercailzie, were turned out on Grand Island in Lake Superior, but these have all disappeared.

Most of the efforts at restocking our covers with exotic birds have been carried on in an unintelligent and aimless way. The belief seems to prevail that because our native species have disappeared-while game birds in Great Britain are still so abundant that good shooting can generally be had-therefore these foreign species are more prolific and better fitted to survive than our native birds. People who reason in this way forget the widely different conditions prevailing in the two countries-the great size of the land holdings in Great Britain compared with those in this country, the fact that trespass laws are there strictly enforced, and the further fact that game is there regarded as the personal 
property of the owner of the land; while in the United States up to within a few years the game has been considered the property of whomsoever might reduce it to possession.

On one side of the water are large estates to which the public is not admitted, while game birds are artificially reared and carefully protected to prevent destruction by natural enemies, as well as by poachers. The result of this is that at the end of a season a crop of game is harvested and sold. In the United States are a series of small land holdings, over which until within a very short time, everyone, man or boy, citizen or alien, was at liberty to roam freely and to destroy at will; the game is left to reproduce itself, is exposed to attacks by its natural enemies as well as by all human beings who may wish to take it, and is only protected by laws which exist on the statute books, but are inefficiently enforced. Here each gunner wishes to shoot, and in practice may shoot, from daylight to dark, seven days in the week. Add to this that a large portion of the public here is accustomed to the use of firearms, and that we have the best guns and ammunition in the world, and it is not difficult to see why game is very scarce in most sections of North America.

In the thickly settled districts of the Eastern and Middle States matters have gone so far that it is difficult to suggest a means by which a stock of birds for field shooting may again be obtained, except the one means, which gunners will adopt last of all, the practice of self-control in their shooting. One result of this 
state of things is that a consiclerable proportion of the men who formerly followed the dog afield, and a very large proportion of their descendants, have taken to shooting targets at the trap, for the reason that within the reach of most of us there are no birds to be had.

I have never advocated the introduction into this country of foreign species of game, believing that our native species answer our requirements better than any foreign birds, and believing also that there is great danger in introducing exotic species into any country. I have believed that by the establishment of game refuges in various sections of the country the native game might be preserved and increased to such an extent that it would overflow into adjacent territory, and that thus in each game refuge we should have a permanent source of supply which would at least prevent the extinction of species for any locality. I feel about the introduction of exotic species much as does Mr. Brewster, who, in his "Memoir on the Birds of the Cambridge Region," says, speaking of the pheasant:

"From the standpoint of the naturalist, the introduction of most exotic forms of animal life must be a matter of regret rather than of satisfaction, and these pheasants, despite their undeniable beanty of form and coloring, and reported value as game, seem deplorably out of place in a New England landscape. Even if they did not crowd out our quail or ruffed grouse-as it has been feared they may-or devastate our cultivated crops-as they are already accused of doing-it would have been much wiser to expend the time and money 
which have been devoted to their naturalization in fostering and increasing our stock of native game birds."

The turning loose of foreign birds to take care of themselves in a climate to which they are unaccustomed and among conditions more or less different from those in which their ancestors have lived, is not likely soon to make much difference in our shooting. A few hundred birds turned loose in a township or a county would have to increase enormously before they would be sufficiently numerous to make the shooting good. Everyone killed would reduce the breeding stock, the process of reproduction would be slow and the final results, even if favorable, might not be important for a generation.

Besides this, there are serious possible dangers in the turning loose of foreign birds. There are some reasons for thinking that these foreign birds carry with them the germs of certain diseases to which they themselves are immune, but which may be communicated to our native birds with fatal results. It is believed by some investigators that the domestic fowl carries with it the germs of a disease which is fatal to the turkey, and to our quail and grouse, although the young of the hen do not suffer from it.

Many examples might be cited of the danger of introducing into a new land an animal, harmless in its own home, but which when transported to a country where conditions are especially favorable to its existence and it finds few or no enemies, has increased to such an extent as to become a nuisance, if not a public menace. The cases of the rabbit in Australia, of the English spar- 
row in North America, and of the mongoose in some of the West Indian Islands, suggest themselves at once.

Happily, within the past two or three years, the experiment of hand-rearing some of our native game birds has apparently advanced well along the road to success. If it cannot be said that any of the public establishments for rearing such birds have been successful in any great degree, it is yet true that they hatch and partly rear many birds. Almost always it has happened that before the birds reached maturity, certainly before they had reached the breeding age, death in some form or other has overtaken them. It was left to a private individual, a professor in a New England university, to take up this matter of rearing native birds as a hobby and to succeed in it beyond the expectation of anyone, possibly beyond his own hopes. Certain it is that Prof. C. F. Hodge, of Clark University, at Worcester, Mass., has strcceeded in rearing from the egg a considerable number of ruffed grouse and quail, which birds are no more timid and fearful of the members of their owner's family than they are of their fellow birds. Not only are they tame in this way, but they manifest no fear whatever of strangers. Within their enclosures they carry on the operations of their daily life with the same unconcern that they would manifest if they were hidden in the depths of one of their native swamps, and this whether human beings are in the vicinity or not. Broods of quail which Professor Hodge has reared and turned out to shift for themselves will come at his whistle, flying from all directions, expecting to be fed. 
Gradually legislators are awakening to the increasing scarcity of bird life about us, and to a comprehension of the invaluable services performed by the birds for agriculture. It has taken the public a long time to begin to comprehend what these services mean, and it is yet, standing only at the threshold of this knowledge. But having made this small beginning, our faith may be strong that this interest will increase, and that before long the birds will be generally recognized as a natural resource of this country which should be conserved.

In a number of the States and provinces the law now provides that there shall be no spring shooting; that non-game birds shall not be killed nor their nests and eggs disturbed, and that the shooting seasons shall be short-not more than two, or at most three months. In some States the laws provide that only a limited number of birds may be taken during one day or during one season. This provision should obtain everywhere, as well as the now very generally accepted view that game birds shall not be sold. In many States we have excellent laws, which, however, lack something of satisfactory enforcement. 


\section{TRANSPLANTING AMERICAN GAME BIRDS.}

It was between the years 1885 and 1895 that the greatest interest was felt in trying to restock the covers of the Middle States with bobwhites imported from the South. They were turned out in large numbers, but, as I have said, did not increase the numbers of local birds because it did not occur to sportsmen to stop shooting. A few men paid for the birds in any locality, and the general public turned out and killed them all, very often without so much as saying "thank you" to the men who had paid the bills.

But bobwhite was not the only native bird which sportsmen tried to introduce on the Atlantic Coast. Efforts have been made at various times to introduce the pinnated grouse of the Mississippi Valley to the old home of the heath hen. This might easily have been done, and could be done to-day, provided only the birds were introduced into game refuges where absolute protection would be assured them. The birds formerly submitted readily to confinement, bore railway journeys well and speedily adapted themselves to new conditions.

While most of these attempts have been forgotten. or remain only as tradition, we have fortunately a record of one of them. This account is from the pen of Mr. N. H. Bishop, well known a generation ago as 
a traveler and canoeist, and was printed in Forest and Strcam in December, 1874. It tells of the introduction of the pinnated grouse and two species of Pacific Coast quail in eastern Maryland. The essential parts of his letter are as follows:

"About five years since a resident of Philadelphia sent to Dr. F. J. Purnell, near Berlin, Worcester County, Maryland, a few pairs of prairie chickens and a covey of both the valley and mountain partridge, or quail. Dr. Purnell has an estate of fifteen hundred acres lying along the banks of Newport Creek, which stream flows into Sinepuxent Bay, on the eastern shore of Maryland. Since the war, this estate has been worked for the Doctor by his tenants. Much of it is woodland and salt meadows. The partridges were for some time kept confined in the house and then were set at liberty. They soon disappeared, except one pair, which returned daily to the kitchen door to be fed. For some cause the pair went to a neighbor's house, on the same estate, and for some weeks were fed from the kitchen door. This pair of birds nested in the garden near the house, and raised a brood of young birds. The covey left their old quarters, and were heard from but once after their departure. A person reported that he saw the covey of 'California quails on the other side of the creek.' This was two years since. It is now supposed that these partridges have been shot by gunners or have died from natural causes.

"The prairie chickens adapted themselves to their new home with but little trouble to the proprietor of the 
estate. Their nests filled with eggs were found along the fences of the fields near the meadows. The birds became tame, visiting the cattle yards, and feeding near the buildings of the farm. They multiplied rapidly. A law was passed by the Maryland legislature protecting them from gunners. The birds seemed to like the large salt meadows of the estate, and exhibited but little fear of strangers. Unfortunately for the birds, a number of terrapin hunters from New Jersey ascended the bay and river in their small vessels. Seeing these tame birds on the meadows, the Jerseymen commenced a war of extermination upon them, which soon resulted in the destruction of almost the entire lot. A workman on Dr. Purnell's estate informed me that he had seen eighteen prairie chickens in the cornfield, near the house, in November of the present year. It was the only covey left by the Jersey terrapin hunters, who came up from Chincoteague Inlet. The same gentleman who sent these fine birds to Dr. Purnell is about to send down from New Jersey the ruffed grouse, called in that State and Pennsylvania, the pheasant. There are no ruffed grouse on the Peninsula."

In Forest and Stream of Nov. 25, I880, Mr. C. S. Wescott reported that a half-grown prairie chicken had been brought to Mr. John Krider, of Philadelphia, for mounting, the bird having been sent from lower Delaware or Maryland with a lot of quail to a Philadelphia game dealer. The bird was not preserved. Mr. Wescott believed - and no doubt he was right about it - that this was a descendant of the birds liberated in Mary- 
land about 1869 by Dr. Purnell. If this is true, it would seem that these birds had survived and bred for a period of ten years, indicating that the conditions were then very favorable in that locality.

About the year I870 a number of birds are said to have been imported from the West and set free on Long Island, where they did well, and reared broods, but finally disappeared. Within two or three years after that the late Shepard F. Knapp, of New York, long a member of the Southside Club and an enthusiastic sportsman, told me of having seen on Long Island two prairie chickens that had recently been killed somewhere near Islip, L. I.

In the year 1874 a number of sportsmen strongly urged the restocking of certain barren areas in New Jersey with pinnated grouse, which had been exterminated there not very long before. Their idea was to import the birds from Illinois, where they were then numerous.

That same year there was talk and correspondence in England and in the United States as to the desirability of importing the pinnated grouse to England and attempting to establish them on the Scotch moors. The price put upon the birds seems to have prevented any action in this direction. Dealers asked $£_{2} 5$ s. per pair for the birds, but later Mr. Chas. Hallock succeeded in finding an animal dealer who agreed to furnish IOO pairs at $\ell_{I}$ Ios. per pair. To-day many sportsmen would be glad to close with an offer such as this.

Mr. Brewster, in the work already quoted, tells of 
an importation of these birds turned out in Massachusetts. . He says :

"In the early spring of I884 or I885, six pairs of prairie hens brought from Iowa were liberated by $\mathrm{Mr}$. Robert B. Nesbitt, of Cambridge, at various points along Concord Avenue, between Belmont and Concord. He tells me that he was afterwards informed-on somewhat questionable authority, however-that several of these birds reared broods of young that season. I can vouch for the fact that a year or two later an adult male spent most of the spring in a grain field near the village of Carlisle, Massachusetts, where it was seen by my friend, Mr. George H. Robbins, and several of his neighbors.

"Another bird of the same sex was met with by Mr. Valter Faxon in the Fresh Pine Swamps (on the Arlington side of Little River) on May I4, I892. The latter instance may be taken to indicate that at least a few of these grouse may have succeeded in maintaining themselves for a number of years, but there are no good reasons for believing that any of them are still living or have left living descendants. In short, the attempts to establish them permanently in the Cambridge region, as well as in other certain parts of Massachusetts where they were liberated about the same time, have evidently proved a complete failure."

Efforts have been made to naturalize various American game birds in England, but so far as known, with no permanent success, except in the case of the turkey, and this only as a domestic bird. In I861 Mr. Grant- 
ley F. Berkeley, a member of Parliament, wrote from Winkton House, in Hampshire, to his friend, Capt. Geo. D. Bayard, saying: "My friend in America up to this last week has been sending me over prairie grouse and quail for naturalization for our society for that purpose here, and I am charmed by being put in mind of the plains, by having a male prairie grouse walking about my garden, tamer than an English pheasant, coming to my whistle for food and making the devil's own howls, with the skin blown out on either side of his neck, strutting and running around and calling for his mate, but I have no mate to give him. The four prairie grouse that came over are all males. A friend of mine, Lord Malmsbury, has imported some of your wood grouse, and they are doing well.

"I have sent out to different places a great number of quails, some from Canada and some from New York."

More than twenty years later Mr. Frank Sturgis, of Chicago, sent a large number of live pinnated grouse to a friend in England, who acknowledged them in a letter published in Forest and Strcam in the following letter from Neath, under date of March 22, I883, as follows :

"I have unfortunately been upon the invalid list at the seaside for a few days, or I would have written at once to acknowledge Mr. Cheetham's letter of the $3 \mathrm{~d}$ inst., and to thank you most lieartily and most sincerely for your princely present of prairie grouse. I am 
sure that I am quite right in stating you have altogether excelled all previous attempts in this direction, and the successful outcome of the shipment reflects the greatest credit upon your excellent arrangements. The birds being so rare, and the quantity so far in excess of any private requirements, I hope you will be pleased rather than offended at the distribution which has been arranged. Acting in concert with Mr. Henry Nash, who communicated with Mr. Lowell, we have presented twenty to her Majesty the Queen, for Balmoral, and the Prince of IVales has been graciously pleased to accept twenty for Sandringham. We have sent ten to the Zoölogical Gardens in Regent's Park, where they are very much prized and valued, and we have turned out sixteen to take their chances upon our Welsh hills-jointly upon Lord Jersey's property and upon shooting land which is leased by the writer. Such of these last birds as have since been seen were all doing well, and I have a report to-day that those which were sent to the Zoölogical Gardens are also well and getting less shy than when first turned out. The birds which were sent to the Zoölogical Gardens are the only ones now in confinement, and it is understood that the society will reserve half of any young birds which may result in case those which are turned out should not increase their numbers. I shall hope to report further satisfactory progress very shortly.

$$
\text { "Philip W. Flower." }
$$

What became of these birds we do not know; that a 
large number of them must have reached their destination in good condition seems obvious, since no less than sixty-six are accounted for in the letter.

Bobwhite was introduced into England in the earlier half of the last century, and is reported to have done well for a time.

No serious attempt has been made to transplant from one part of America to another any others of the grouse, except that one or more consignments of sharptailed grouse are said to have been shipped to Massachusetts, where they were turned out and disappeared. Sharp-tailed grouse were planted also on Grand Island in Lake Superior, but this is in or close to the native range of the species. What the fate of these Grand Island sharp-tail grouse may have been we do not know. Possibly they shared the fate of the exotic grouse there introduced, all of which, we are told, have disappeared.

We read in the accounts of the early Spanish explorers that the wild turkey had been domesticated by the Indians before the white man's coming. A considerable portion of the sustenance of certain Florida Indians was drawn from their turkeys, and we are told that the carnivorous animals in the great zoölogical gardens kept up by the Aztec, Montezuma, were fed on the flesh of turkeys.

The domestic turkey is a descendant of the wild turkey of the Southwest. The bird was carried to Spain and thence spread over Europe, finally reaching England. That the common wild turkey of the East 
may also be domesticated has been shown by experiments carried on, on a plantation near Farmville, Va., by Prof. Robert Lee Blanton, an account of which was published in Forest and Stream, vol. 74, p. 450.

When, if ever, game refuges shall be established in the various States-game refuges properly protected, be it understood-they should be stocked with wild turkeys. 


\section{DESTRUCTION AND PROTECTION.}

Where game birds are left to look out for themselves, civilized man and the conditions he brings with him constitute their most destructive enemy. It is not so much the number of birds killed by man as the changes which he works in the land that affect the birds and often make life impossible for them. Of these changes, the most important is the clearing up and cultivation of woodland-the cutting down of forests and the draining of swamps. Most wild creatures require cover to afford them shelter from their enemies, while the farmer wishes the ground to be free from all cover except that which his crops afford, and these crops are standing for a few months only. Without cover, the quail, the wild turkey, the grouse and the woodcock cannot exist. Wild birds depend for safety largely on their protective coloring, which makes it easy for them to escape notice in their chosen haunts, and on their habit of flying - on the approach of danger - to refuges where they may hide. But if forest and brush are cut away the partridge and the quail have no places in which to seek safety; if the tall grass of prairie sloughs and ravines is mowed and the soil ploughed up, the prairie chicken is without place of concealment; if the swamp is drained and the alders, birches and spice536 


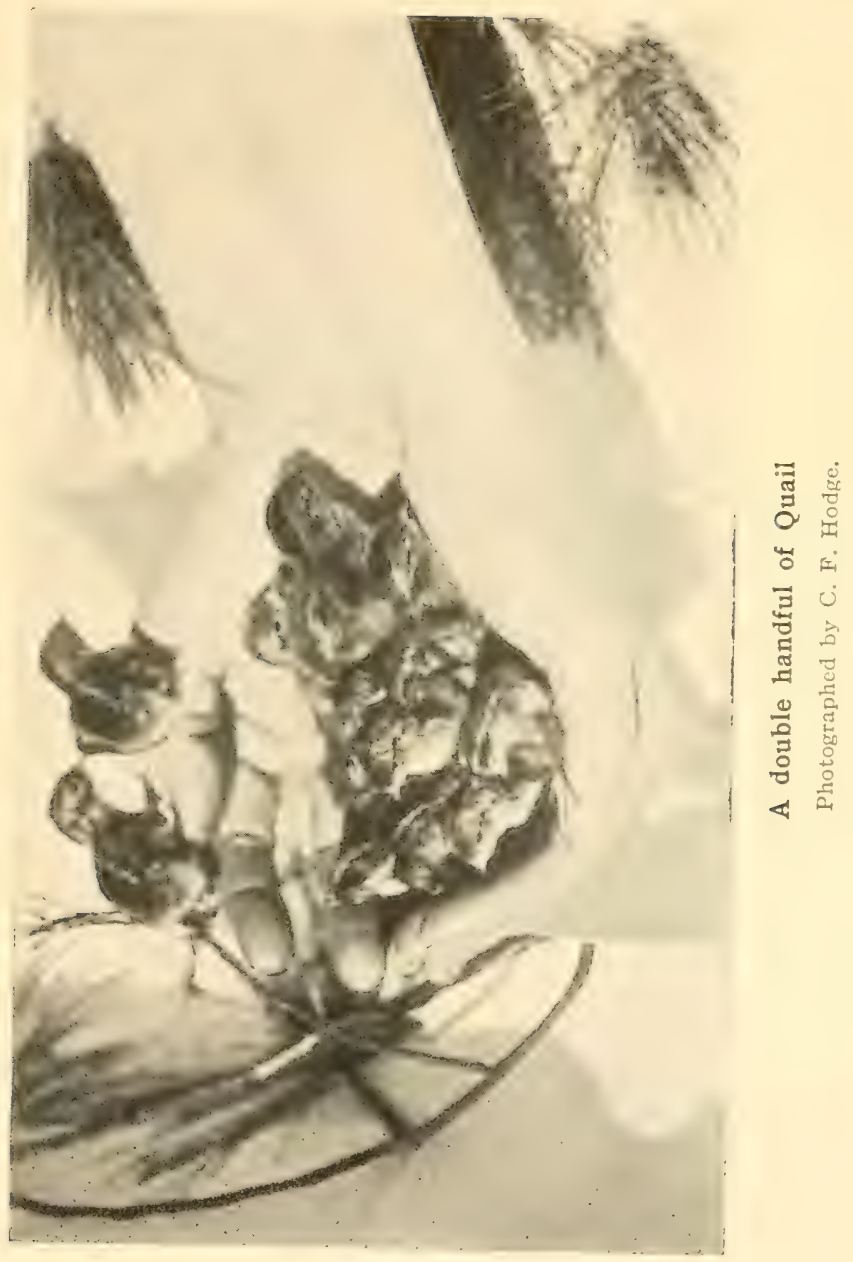



wood that grow in it are cut down, the woodcock no longer has a home.

While all these changes are going on, gunners are lecoming more numerous. With the settling up of the country there is an increasing demand for the flesh of game, and, between the attacks of man, the destruction of their old homes and the ravages of predatory birds and mammals, in many regions the game birds have been almost exterminated.

Among their natural enemies are all the carnivorous mammals, many of the hawks and owls, and not a few domestic animals. In the old times, when birds were less pursued by man and had a range far wider than at present, their annual increase in numbers more than made up the loss from the attacks of natural enemies, but over much of the territory of the United States that time has long passed.

In thickly settled countries, the domestic dog, selfhunting through the spring and summer, destroys great numbers of the nests and eggs of song and game birds, while the house cat, the pet of the kitchen or the house cat run wild, is very destructive. The harm done by the farmer's dog in his travels through the fields is not generally understood. Two or three dogs from neighhoring farms may start out in company and be gone all day-perhaps for several days--hunting. Among the prey that they capture may, perhaps, be a woodchuck, the remains of which the farmer finds later and speaks of with pride as having been killed by his dogs. He does not know that while hunting the dogs may have 
destroyed dozens of the nests of game birds and songbirds, which are the farmer's best friends, since they are ever-working unpaid police officers, destroying all through the summer days the insect enemies which prey upon his crops. If the work of these insect-eating birds were to be stopped for a week, or for a month, the damage done to the crops of the United States would be incalculably great.

In certain sections of the South an extremely destructive enemy of ground-nesting birds of all sorts is the wild hog, which roams the forest, literally seeking what he may devour. The number of nests and eggs of turkeys, ruffled grouse and quail that these animals search out and destroy is very great. Some States have laws providing that hogs shall not be allowed to run at large, but such States are exceptions. On the other hand, it must be said that in States so thinly settled that hogs and cattle are permitted to run wild, there are comparatively few dogs and cats that roam the fields and woods.

Mr. Herbert Brown reported a few years ago that previous to the introduction of ranch cattle the masked quail was quite common in southern Arizona, but that the cattle eating off and trampling down the tall grass had so destroyed the breeding and hiding places of this bird that it had practically disappeared from the United States side of the line, and at latest reports this was still the condition, as is seen by what he says on page 64. Under such adverse conditions, it is not strange that our stock of splendid game birds grows smaller 


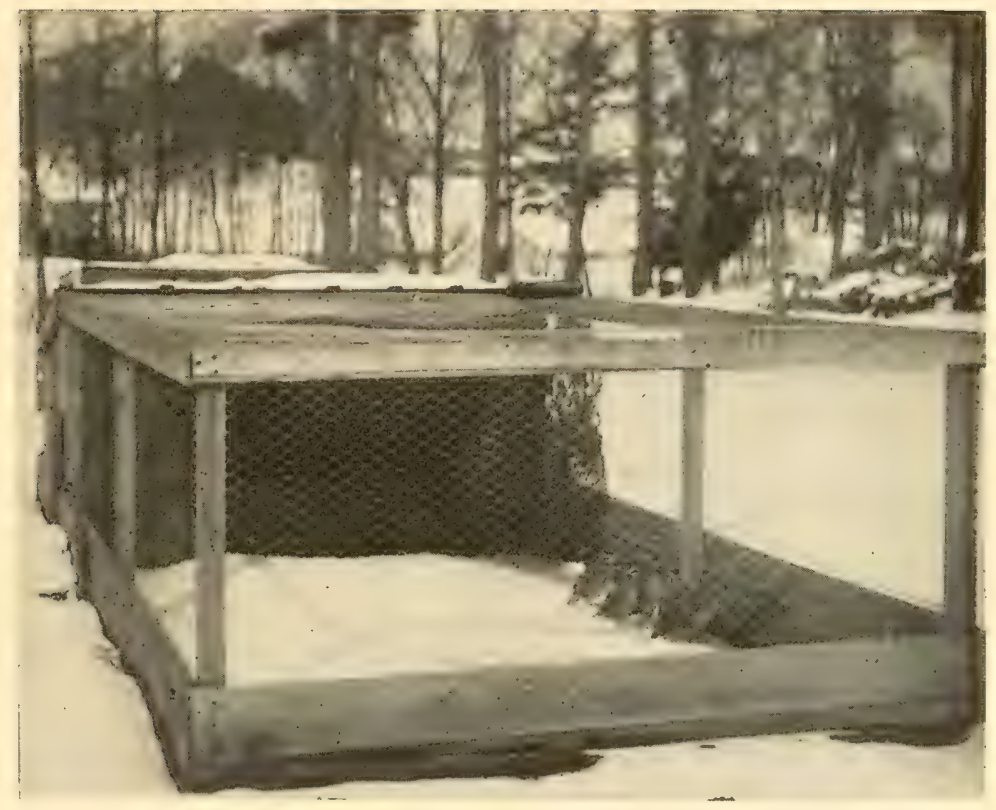

Winter quarters of Dr. Hodge's Quail.

Photographed by C. F. Hodge. 

year by year. The problem as to what shall be done to keep this stock from wholly disappearing gives cause for much anxiety.

For American sportsmen, American game birds are the best, and there is no reason why we should not have an abundance of these, provided only for a short time we practice a little self-control. The wild turkey was formerly found over the whole United States, east of the Missouri River, south of the Niobrara and east of the Rocky Mountains. Grouse of one sort and another formerly abounded over almost the whole United States and Canada, while in the southern portions of the United States there were great numbers of quail. These birds sportsmen may bring back, in large measure, if they care to; but they cannot do this by killing them at every opportunity. All these birds are prolific and probably all can be hand-reared. If this can be done, they may be turned out in numbers on game refuges-if these shall be established-and if absolutely protected there, will soon spread themselves over the surrounding country. They must be protected, however, alike against the gumner and against the attacks of their natural enemies.

It is not yet fully known what might be done with our grouse and quail, but the experiments of Prof. C. F. Hodge, of Worcester, with the ruffed grouse and bobwhite, justify the belief that all grouse may be reared in confinement. A short period of experimentation by men interested in the subject will probably result in the semi-domestication of practically all the 
American grouse. These birds, so reared in their natural ranges and then set free in refuges, would restock covers now barren. The process of restocking could be kept up indefinitely, and after a time at a very modest cost. If one-half as much time and money had been expended in attempts to domesticate or handrear some of our native species as has been devoted to the importation and rearing of exotic forms, the problem of our game supply would now be much simpler than it is.

With the Limicoline birds the case is somewhat different. No experience has been had with them, and nothing is known about confining them or inducing them to breed in confinement. On the other hand, as migratory birds they are exposed to the gunner only for a short time, and then pass on to sections less thickly settled, and where, therefore, the dangers are less.

In the United States most of the efforts to rear game birds have been devoted to foreign species, but to this rule the State of Massachusetts is a notable exception. On its public game farm it has for several years consistently tried to rear quail and ruffed grouse, and though not altogether successful, much experience has been gained.

It was left to another Massachusetts man, Dr. Clifton F. Hodge, working from pure love of his task, to accomplish the greatest results.

The work done by the Massachusetts Commissioners of Fisheries and Game, and by Dr. Hodge, is set forth 


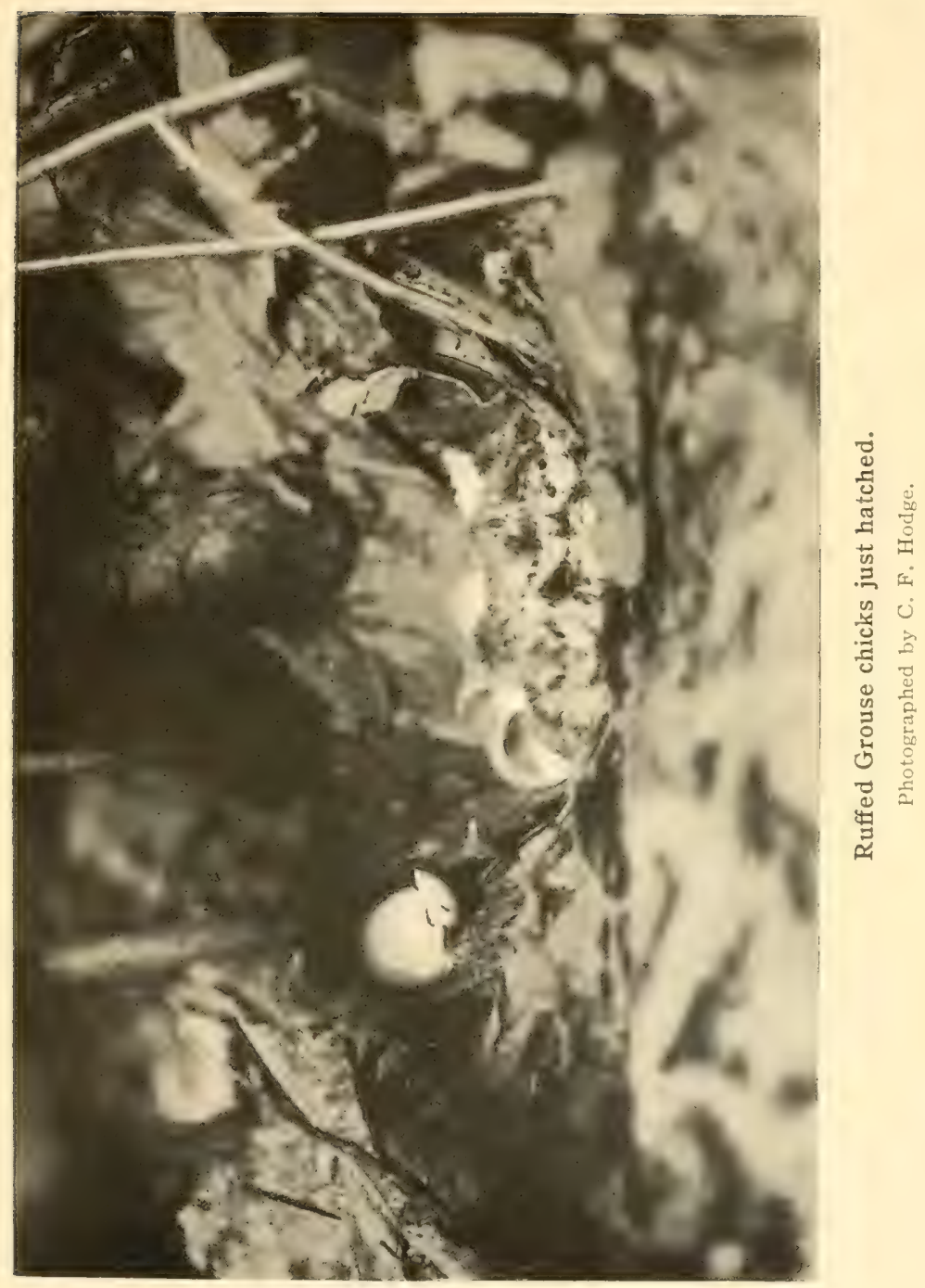



at some length in the Reports of the Massachusetts Commissioners for the years 1907 and 1908 .

In 1907 the efforts of the Massachusetts Commissioners to rear ruffed grouse in confinement resulted in little more than the acquisition of some experience as to what not to do. It was learned, for one thing, that the males are extremely disposed to fight. During the winter, in a pen of three young birds one male killed another with which it had grown up. Even during the mating season there was need of great care lest the male kill the female. His attacks on the females caused them great alarm, since it was impossible for them to escape from the cage, and they hurt themselves in their efforts to do so. In fact it was not safe to put the male in the coop for mating without closely watching him, and it was necessary to remove him almost at once.

The birds in the coops of the commission soon became noticeably unafraid. They paid little attention to what was going on outside, and did not display the timidity and restlessness of the bobwhite. It was observed that they ate with appetite and appeared to enjoy their food. Nevertheless, the male grouse died late in the summer, evidently from an infectious disease communicated to him probably through infected ground.

No one has approached the success which has attended the work of Prof. C. F. Hodge, of Clark University, who for some years, as a rest and recreation from his ordinary work, has been trying to rear ruffed 
grouse and quail in domestication. His experience is extraordinarily suggestive, and we quote much of his report to the Massachusetts Commissioners. His permits for the year allowed him to take 8 o eggs of the ruffed grouse and to keep three pairs of bobwhite quail for purposes of propagation. He had 54 grouse eggs, from which 38 chicks were hatched, and of these he says:

"As will be seen, the eggs did not hatch as well as in the previous years of experiment, possibly due to cold weather in May. The eggs were all hatched under Cochin bantam hens, as usual. Chicks are accounted for as follows:

"Fifteen chicks, June 6th, left with hen mother, began dropping off after the first two weeks, and were all dead by August I 5 th.

"Fifteen chicks, June 6th, transferred on morning of hatching to brooder; 2 escaped, I died, probably as result of accidental injury, 2 died from swallowing objects too large to pass into the gizzard (black cricket and large spider), io are healthy, well-grown birds at present.

"Eight chicks, June Igth, transferred to brooder, and all did well, until, on sudden change of weather, temperature ran too high and killed them all.

"The experiment was conducted this season on my new place, on uncontaminated ground, and I thought it desirable to try once more the simpler method of rearing with the hen. The result is decisive against this method. The fact that the hen carries parasites, 
which are likely to prove fatal to young grouse, probably explains why our native species have not long since been domesticated. All former attempts to domesticate them have been made in the poultry yard and its environment. The same is now being proved to explain why the turkey, another native American species, cannot be reared on ground contaminated by domestic fowls. This is the fifth year in which the experiment of rearing ruffed grouse with bantam hens has been tried, and although the second year 6 birds were reared out of a clutch of 12 , for all the other years fatalities by this method have amounted to Ioo per cent. This season is particularly decisive because the work was done on new ground under most favorable conditions, with the benefit of past experience, and in clear competition with the brooder method."

On the other hand his experience led him to believe that except for accidents, practically every ruffed grouse chick hatched may be reared to maturity by the brooder method. Brooders connected with yards in which the chicks may run during warm days offer a method which is not expensive. The young develop and feather out rapidly, and except for the two first weeks need no artificial heat, except during cold storms.

Professor Hodge suggests the possibility of rearing a strain of hens to be hatched in incubators and reared on uncontaminated ground which possibly might be safe for mothers and brooders.

Professor Hodge found the bobwhite quail much easier to handle than the grouse, and experimented 
with a single pair kept as pets in the house. The hen laid I8 eggs in a nest made by the pair in a window cage, but since the birds did not seem inclined to incubate, the eggs were placed under a bantam hen. Of the 13 eggs first laid 6 hatched, but the chicks being left with the hen all died within ten days. Of the remaining 5, 3 hatched under a second hen and to these 5 eggs were added I I obtained from the State Hatchery. Ten chicks were obtained from the I6 eggs. Of these, 3 died by accident and showed no trace of the disease of liver and creca which has proved fatal to so many of our young game birds as it has to turkeys. The remaining 7 birds did well from September to the date of this report, November, I907. Eleven quail chicks just out of the incubator were obtained August Igth from the State Farm, were reared in a brooder and to date are alive and well.

One of the great difficulties attending these efforts to rear native game birds has been the persistent attacks of vermin, and this Professor Hodge was able to wholly guard against during the summer of 1907. Rats were troublesome, a skunk killed a hen quail, and a multitude of skunks were about. Traps were kept constantly set and the results were surprising-for it must be remembered that Professor Hodge lives in the large city of Worcester. These traps caught I7 skunks and a great number of rats, and all these before any damage had been done by the animals. Professor Hodge is carrying on this interesting experimental work purely as a labor of love, though in Igog a grant of 


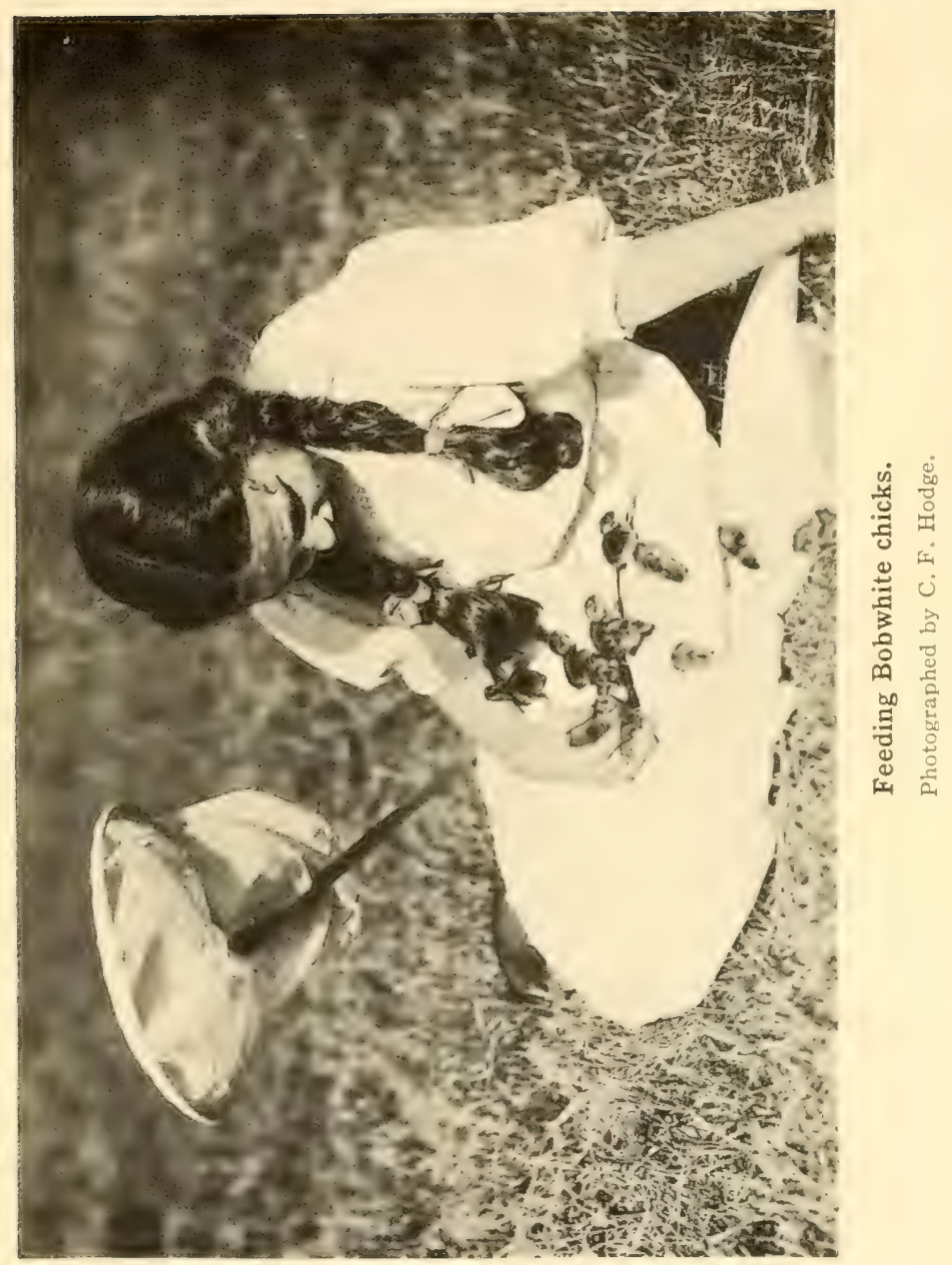



$\$ 500$ from the Carnegie Institute paid a portion of the expenses.

The work of the Massachusetts State Farm started in the year of 1906 with a flock of breeding quail numbering 47. At the close of the season a partial count indicated 30 , and at the beginning of winter $2 \mathrm{I}$ were left, while at the opening of the breeding season of 1907 there were but 12 , or only about 25 per cent. of the original number.

A number of chicks were hatched in incubators, and this method seemed to Arthur Merrill, the superintendent, more successful than the use of hens. The loss from dead embryos was less than the usual breakage of eggs, and the chicks were stronger. The incubators were run in the same manner as for pheasants.

The young quail were fed on dried ants' eggs and maggots, live ants' eggs and insects being added when practicable, with fruit, seeds and grain as the bird grew older. Insect food is unquestionably most desirable for young birds, but it is difficult to obtain. Berries, grasses and clover, or indeed almost any green food, are essential, but difficult to secure. On the whole, up to the close of the year I9o7 the experimenters had learned chiefly what was to be avoided, and not what was to be done.

In his report to the Commissioners on Fisheries and Game of Massachusetts for the year ending December 3I, I908, Professor Hodge gives at length his experience for the previous season, writing under date of November 27 th. Little could be done toward experi- 
menting with ruffed grouse, yet one clutch of 12 eggs was secured, Io of these hatched and 3 reared to maturity. In the loss of 7 of these chicks a very important discovery was made. Insect food being essential to the young birds, a large number of striped plant bugs were obtained by sweeping the grass where they were abundant with insect nets. The young chicks ate them eagerly, and went to sleep and died as if they had been chloroformed. Professor Hodge points out that these bugs give out a strong odor similar to that of the squash bug, and Conradi found that when squash bugs were fed to toads, these died as though poisoned with chloroform. While Conradi found that 5 or 6 squash bugs might be sufficient to kill a toad, Miss Morse has fed as many as I I to bobwhite at a single meal with no apparent ill effect. Toads ate the plant bugs in large quantities without injury, but it is apparent that strong-smelling bugs should not be fed to young ruffed grouse.

The experiments with bobwhite proved very successful. The season began with 5 pairs and several extra cocks. The first egg was laid by May 6th, and 4 of the hens had begun laying by May Ioth. Not less than 247 eggs were laid, an average of 49 to the pair, but Mr. Merrill, of the State Game Farm, had a hen quail which laid Ioo eggs. Two of Professor Hodge's hens died during the summer, but the 3 that survived laid an average of 65 eggs each. In all II 4 chicks were hatched and 75 reared. A most excellent showing, but one that will unquestionably be greatly 


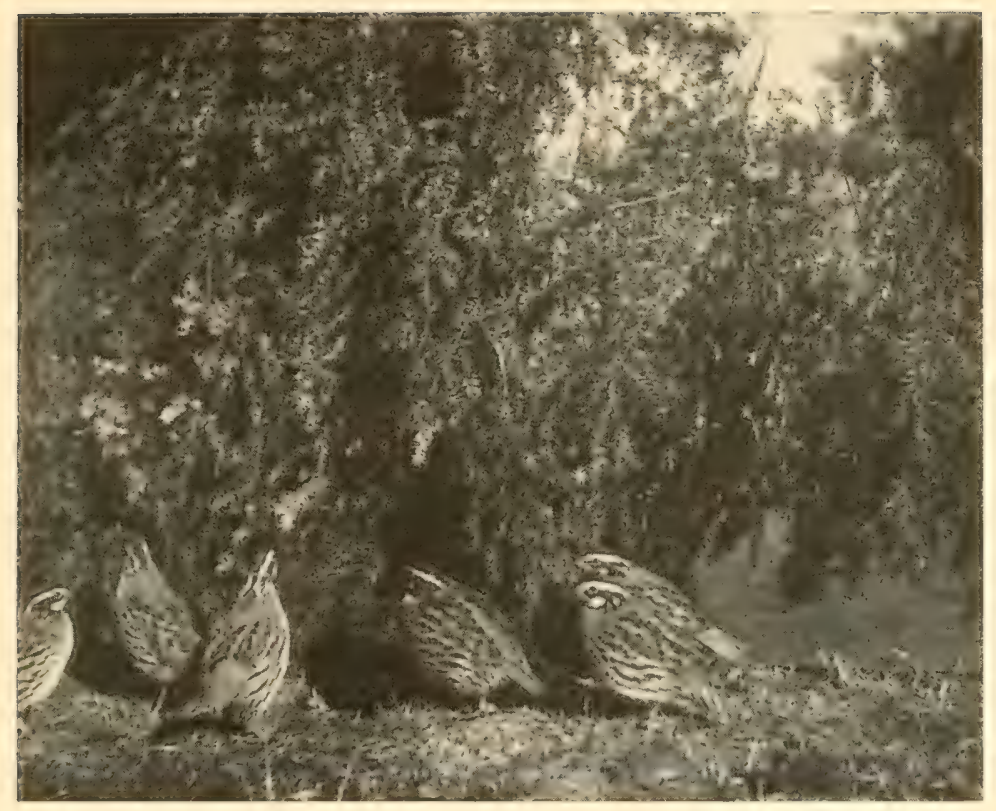

Bobwhite reared by Dr. C. F. Hodge. 

improved on as time goes on. Professor Hodge's letter on his experiments shows extraordinary progress made in learning of the lives of these birds.

There is a wide range of difference in the actions of different pairs of bobwhites, especially in respect to breeding and care of young. One pair which occupied a large cage with the ruffed grouse got along with the larger birds without any trouble; the hen laid 58 eggs, making and filling several nests. On August 20 th the cock began brooding a nest with 16 eggs, and on September I $3^{\text {th }}$ hatched I5 chicks. Both birds joined in the care of the brood. Another pair had occupied a cage 6 by 12 feet and produced in all 69 eggs, but neither bird showed any signs of brooding. The cock, however, took charge of and reared a brood of chicks, hatched under a bantam, but while he was doing this the hen quail refused to associate with him. A pair was kept in a cage 3 by 6 feet and produced 68 eggs, all laid in a single nest. The eggs were taken away from time to time, because neither bird showed signs of brooding. Nevertheless, on the 9 eggs last laid, the hen began to sit September I 2 th and brought out 9 chicks October 6th. The cock was attentive to his mate on the nest, but was seen sitting on it only once for a short time, while the hen was feeding. Both birds joined in the care of the young. Of the two unmated cocks one adopted and took care of a brood of chicks hatched under a hen, while the other refused to care for the chicks, pecked them savageiy and would probably have killed any that had been left 
in his cage. It is evident, therefore, that a cage 3 by 6 feet is not too small for quail to do well in; a fact of interest, for it renders the work of experimenting in this matter practicable for almost anyone.

Some temperatures of these birds were taken, and it was found that the interior body temperature of a brooding male bobwhite was no less than I I d degreesremarkably high. The brooding quail gives the eggs rather long periods of cooling once or twice a day. The records thus seem to suggest for incubators a temperature one or two degrees higher for quail than for domestic fowls. It has been noted also that the chicks of the ruffed grouse and the quail seem to thrive much better when the brooders are kept much warmer than is advised in the directions for domestic chickens. This is necessary, apparently, only for the first ten days or two weeks, but for that time it seems well to keep the temperature five degrees higher than required for domestic fowl. The conclusion thus reached was confirmed by an experience in September when, of 68 chicks in brooders, 24 died in two days.

Professor Hodge's explanation of the "brooder troubles," which have caused the death of so many apparently healthy birds, seems wholly plausible. He regards these troubles as acute indigestion and suggests a remedy. He gives elaborate directions for feeding, lays an especial stress on lining brooders, which should have no chinks or cracks into which one of these tiny birds may creep, on keeping them free from infection from domestic fowls, and on giving the birds 
sufficient water and a warm dust bath. These two things, he believes, attach the birds strongly to a homing place. His birds were at liberty during the day. He says:

"The little fellows have an affinity for brush patches, corn, asparagus beds, or any sort of natural cover, like that of ducks for water. Instead of proving the nuisance that I at first feared, this affinity may be turned to excellent account if properly indulged and arranged for. I always keep a little brush-pile, with an armful of hay or freshly cut weeds thrown over it, in the home cage. This also attracts them to the place. If they have located in a clump of bushes or a weed patch, they are safe for the day. Should a thunder storm come up, and the birds are as tame as they should be, they can be whistled home, or an insect net be put over the entire cluster and they can be carried into the brooder. When they began to fly in the second week, I expected to be obliged to clip their wings. I did not do this, however, and, as the sequel proved, their ability to fly is a great advantage in rearing them. Within the past few days a wind storm opened one of my cages containing adult and young birds. Though able to fly for miles, I drove them back into the cage as easily as if they had been a flock of little chickens. During the summer the flocks would range out afoot to feed and fly home. In feeding the birds I used from the first a low whistle, in imitation of the feeding note of the chicks themselves. On coming home at noon or night the flock might be 
nowhere in sight, but on giving the whistle I would be assured by a chorus of eager replies, and in a moment the air would be full of whirring wings, as the flock flew in with a rush and lighted at the entrance of the cage. This might be repeated as many as a dozen times a day.

"Wintering the bobwhite offers no difficulty. I set the cages with the shelter end open to the south, build a brush wood-pile in the middle of the cage, see that they are supplied with weed seed, grain mixture and water when snow is lacking, and keep a cabbage, a mangel wurzel or an apple where they can pick at it. It might be well to see that the cluster is not imprisoned under the ice after a sleet storm, but the brush-pile has afforded insurance against this so far. This brush wood-pile is made by placing a few stout branches on the ground in a sheltered sunny exposure, and on these pile about two feet of weeds, cut before the seeds fall-ragweed, lamb's quarter, pigweed, smart-weed, wild buckwheat (chaff straw or loft sweepings would do if weeds are not at hand) ; then pile on a foot or two of stout brush which cannot be crushed down by heavy snows, and on top of this place a good thick covering of weeds. This will give the flock scratching material all winter, afford shelter from cold and storms, and protect from vermin, especially hawks, owls and cats. For bobwhite in the open I think this simple winter provision would insure against winter killing and extend the range of the species at least several hundred miles to the north. The great value of the bird in 


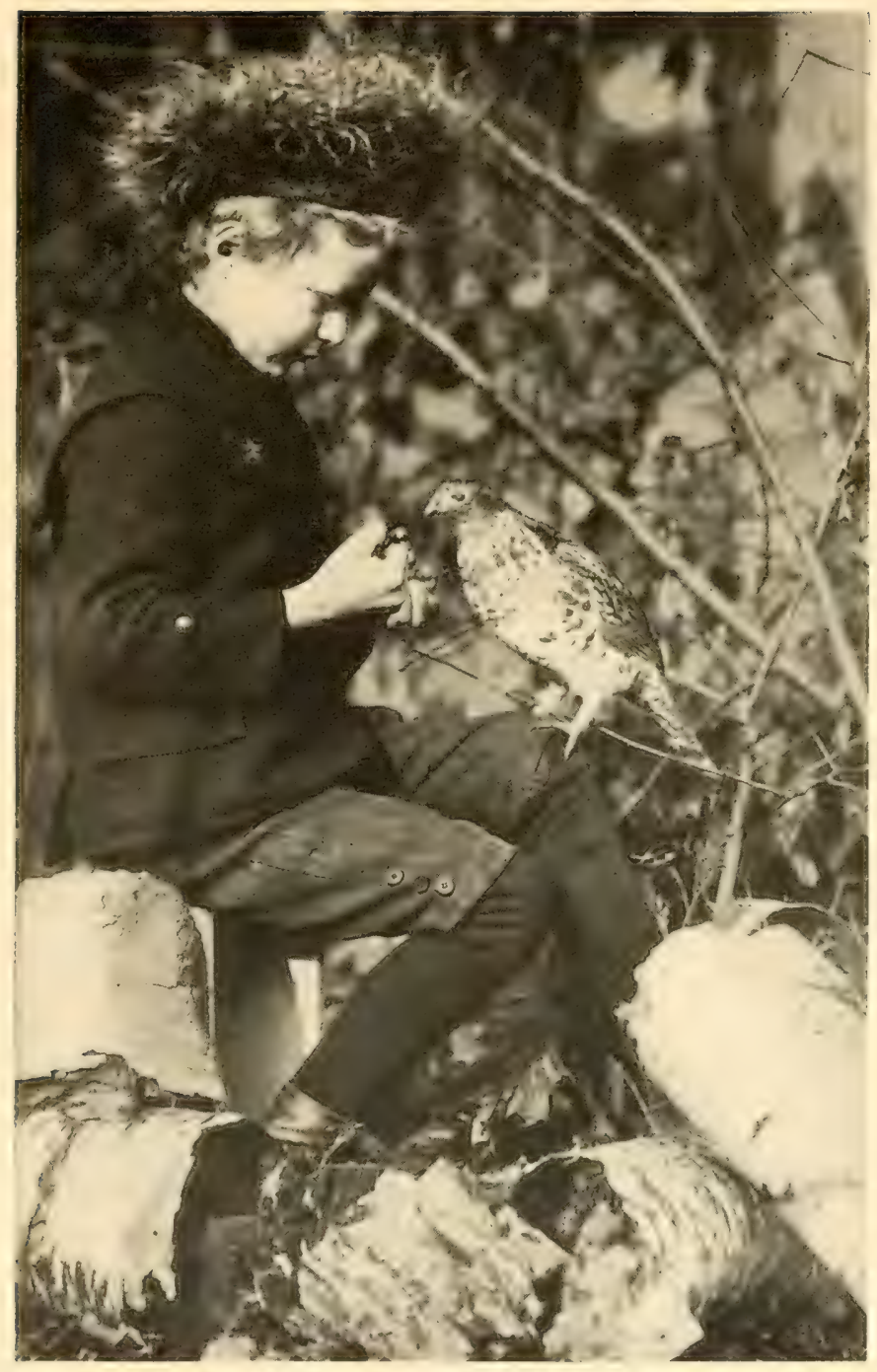

Ruffed Grouse feeding from hand.

Photographed by C. F. Hodge. 

insect and weed seed destruction will amply repay farmers for their work.

"As spring comes on the cocks fight a good deal; but still breeders generally advise keeping several pairs in the same cage. I tried both methods this season, keeping four pairs in the same cage ( 6 by 12 feet) through May and June. They laid well under these conditions, but there was so much disturbance and persecution that there was little hope of either hens or cocks beginning to brood. Each pair was then given a separate cage, and they did so much better that this plan will be generally adopted in future."

Professor Hodge gives various suggestions replying to many inquiries that have come to him, as to practical methods of rearing bobwhite. What he has said, however, applies equally to the ruffed grouse and probably to the prairie chicken as well. The results which he has obtained in six years of experiment will appear to most people very gratifying and very encouraging to further experimentation in this field. He very truly says :

"We now see clearly that we must bid farewell to all our native game birds or work out methods of propagating them."

Besides the birds in question Professor Hodge experimented with a pair of sharp-tail grouse from the Saskatchewan. The birds did very well and Professor Hodge discovered that they were exceedingly fond of clover. No doubt if he had given them alfalfa they would have eaten it with still greater relish, since, in 
their natural range, whenever the alfalfa is green, these birds resort to it, and for a part of the year it seems to constitute one of their chief foods.

The hen prairie chicken laid ten eggs and then died, showing intense infection with coccidia, which appears to be the bane of so many of our native birds, including the domestic turkey. Five of the eggs were hatched under a bantam hen, but all died in Professor Hodge's absence from home. He was promised eggs or breeding stock in prairie chickens for the following year, and hoped to experiment with them.

In I909, however, circumstances prevented his work on the problem. He reared three ruffed grouse and fourteen quail, and in I9Io, owing to the pressure of affairs he turned over his breeding stock to the Massachusetts Commission.

While Professor Hodge was doing this work at Worcester, the superintendent of the Sutton Hatchery, the Massachusetts Game Farm, was studying the same problems. The restlts obtained were not great in the number of birds, but much was learned as to the most serious disease likely to be met with, and the adaptability of quail and grouse to domestication. It was found that disease rather than the method of feeding is the controlling factor in rearing the young. One hundred and twenty-two ruffed grouse were hatched, but all except 2 birds were lost, though I I lived to the age of seven weeks. Many of the deaths were due to coccidium, and others to what is called by the writer "brooder pneumonia," and the inference drawn from 
the report is that many of these young birds received infection either from the hens which hatched them, or from the ground on which they were reared, this ground being a place where poultry had been kept. English pheasants appeared to be more resistant to disease than the grouse and quail.

During this season most of the eggs laid by the quail were well fertilized, and no quail failed to lay. Four hundred and seventy eggs were laid and 222 hatched. There seemed no advantage in penning the birds with a greater number of females than males, and during the season of 1907 , when the birds were paired, results were much more favorable than before. In a number of cases the males were active in caring for the chicks, and in one case a male adopted and reared a clutch of young ones. While in earlier attempts at hatching, much loss was experienced from breakage of eggs by the bantam hens, and while the next year incubators were used, hatching 80 per cent. of the eggs, during the season of 1908 incubators were unsatisfactory, while hens did much better than before, the greater number breaking no eggs at all. In other words, the result of each season shows the importance of more and more experiments on the part of those who have these matters in charge, and as they acquire this experience their success will, of course, be greater.

The food difficulty remains, but in this matter much also is being learned.

Like Professor Hodge, Mr. Merrill concludes that there appears to be no advantage of large pens over 
small ones. To be sure, the birds found some insect food, but this was soon exhausted. Small pens have given entire satisfaction for wintering quail and grouse, the only difficulty being wet and dampness when snow melts. The pen should be kept entirely dry, and should be open to the fresh air.

A better comprehension of the mating and nesting processes of the quail and ruffed grouse is very necessary. The breeding of the grouse is complicated by the uncertain and quarrelsome temper of the male. The problem of hatching, like that of food, requires further study. Meantime, of course, the work of bacteriological investigation must be kept up, for one of the first problems in rearing these birds is to understand the diseases to which they are subject under these new and unnatural conditions.

The success of the Sutton Farm with pheasants has been better than with our native game, but even so has not been at all satisfactory. 


\section{CONCLUSION.}

In view of all our experience it is clear that American sportsmen cannot continue to kill off their game and still to have their covers full of birds. I believe that a time will come when there will be good shooting in many parts of the country, but this will not be until gunners have been taught the lesson of self-control. Methods must be devised for restocking our fields and woods, and the birds put out must have an opportunity to live and to reproduce their kind. This means better enforcement of law, shorter open-seasons and a bag limit. As conditions precedent to good shooting, must come also game refuges and the private preserve. If sportsmen long ago had been wise enough to demand from the legislatures the establishment of game refuges, we should now have public preserves which might have been large enough for anyone. Instead of demanding this, gunners often grumbled bitterly when land owners posted their fields and declined to allow everyone to run over their land, tear down their fences and shoot their domestic fowls, and even their animals.

The private preserve has come to stay, and it is a good thing for gunners at large that it has come. What the general public should now demand is game refuges-public preserves-where the birds may increase and from which they will certainly scatter out 
for the benefit of the general public. By the time such refuges have been generally established the problem of rearing our game birds will probably have been solved, and from that time on there will be little difficulty in our finding each autumn a few birds on which to work our dogs and exercise our skill in shooting.

Only a few years ago the shooting seasons commonly began on September Ist and closed January Ist. Now in most States-above all in those States where birds are least abundant-the shooting season lasts for two months only and often closes December Ist. Almost without our noticing it the length of the season has been reduced one-half. In many States bag limits have been established, and while too often these limits are disregarded, the sentiment that this law should be obyed is constantly growing stronger.

Everywhere sportsmen might accomplish much more toward increasing the supply of game if they were organized and would work together for a common object. In some States organizations have been effected, but sufficient interest has not yet been aroused to make them ready to work together for the common purpose. Sometimes, too, the organization is brought together more for the purpose of making a showing or redounding to the credit of some one individual than it is for actual fish and game protective work, and when this takes place, the organization becomes a mere name, wholly inefficient for practical purposes. The State of Connecticut possesses an organization 
modeled on right lines. There are town gun clubs, which are members of the County Game Protective Association, and these County Game Associations choose delegates who are members of the executive council of the central State Game Protective body. The town gun clubs are active and especially interested in their own especial territory. The occasional meetings held where all the towns of the country are represented, keep up this interest, and when the county delegates attend the meetings of the State Association they are able to report intelligently on what is taking place and on what should be done. If every State in the Union had such an organization, and if every State from time to time chose delegates to a central association which represented the English-speaking race on the continent, matters would go forward much more rapidly, and much more would be accomplished than at present.

Another thing that works against the sportsmen is that they have no method of communication with each other. The means are at their hand in the various sportsmen's journals, but only a small proportion of the great number of gunners in theland read these journals. If they were read by most sportsmen, who thus kept themselves informed as to what legislation is on foot and what other sportsmen are doing, intelligent action could be taken by a large body of men on the measures which should be taken to increase our stock of game. Sportsmen would then be acting together as one body, and many of the problems which now trouble us would have been solved. 
It is worth the while of all who are actively interested in having our game supply increased to keep themselves informed of the legislation that is taking place, of the progress that is being made in the artificial rearing of fish and game, and above all of the views and opinions of other sportsmen. Unless those interested in this subject are willing to work together and to bring their united intelligence and influence to bear on the public, the reforms will come only slowly.

The objects which sportsmen must work for are, the enforcement of the laws that we already have, and the passage and enforcement of better laws.

Among the better laws needed are, first, statutes authorizing the establishment of game refuges; second, the prohibition of the sale of game; third, short shooting seasons and a reasonable bag limit.

Many of the States now insist on a payment by gunners of a shooting license fee, and in many States the aggregate of these fees amounts to a great sum. It is proper that a large share of this money should be expended for the benefit of those who pay the tax, and a proportion of that expenditure should be for intelligent experimentation in rearing our native gamebirds.

During the past twenty years great progress has been made in game protection. To-day more interest is felt in this subject than ever before, and more money is available for it. If sportsmen will work together to a common end, the next ten or fifteen years should see in many parts of the United States better shooting than has been had there for a generation. 







